Rômulo Andrade de Oliveira

\title{
Brasília e o paradigma modernista: \\ planejamento urbano do moderno atraso
}

\section{Dissertação apresentada à Faculdade de Arquitetura e Urbanismo da Universidade de São Paulo para a obtenção de título de Mestre em Arquitetura e Urbanismo}

Área de Concentração:

Planejamento Urbano e Regional

Orientador

Prof. Dr. João Sette Whitaker Ferreira

São Paulo, 2008 
AUTORIZO A REPRODUÇÃO E DIVULGAÇÃO TOTAL OU PARCIAL DESTE TRABALHO, POR QUALQUER MEIO CONVENCIONAL OU ELETRÔNICO, PARA FINS DE ESTUDO E PESQUISA, DESDE QUE CITADA A FONTE. ASSINATURA:

E-MAIL: lo.ol@ig.com.br

Oliveira, Rômulo Andrade de 


\section{AGRADECIMENTOS}

À Alessandra, minha mulher, que sempre esteve ao meu lado com muito carinho e preocupação nos altos e baixos desse processo, que foram muitos. Sem ela, finalizar esse trabalho com certeza não seria viável. Uma revisora especial deste trabalho.

Ao meu orientador Prof. João Whitaker pela paciência e por me permitir ir além.

Ao meu pai José, revisor de texto generoso em conselhos, do latim ao grego não faltaram citações; e à minha mãe Leni pelo terno carinho e preocupação eterna. $E$, aos dois, que sempre me incentivaram e apoiaram nas boas loucuras da vida, essa foi uma delas.

À minha irmã Rosângela por sua eterna ternura

Ao meu irmão Regis e a minha cunhada Márcia pela alegria.

Aos meus queridos sobrinhos Rafael e Luíza,

Ao meu sogro Sérgio pela revisão de texto criteriosa e paciente e à minha sogra Sheila pelo incentivo constante.

Aos meus cunhados Fernando e Renata pela atenção carinhosa.

Às minhas amigas Natasha e Milena com as quais compartilhei dúvidas e angústias comuns desse processo de pesquisa.

Aos meus amigos de São Paulo que são muitos e muito queridos que colaboraram com boas conversas e angústias compartilhadas: Eduardo, Isadora, Rôga, Marília, Gustavo, Márcio...

Aos meus amigos de Brasília pelo incentivo e disposição em me ajudar e contribuir, em especial a Roni amigo de longa data e que foi um companheiro de última hora. 


\section{RESUMO}

O trabalho teve como objetivo observar o trajeto da implantação do planejamento urbano modernista em Brasília e seus resultados. Em outras palavras, entender o resultado de implementar um modelo de planejamento urbano moderno, mais adequado a países já industrializados, em uma sociedade que, segundo Francisco de Oliveira, combina o moderno com o atrasado. Para isso, optou-se por fazer primeiro uma leitura de Brasília como objeto de uma política nacional que visava à ampliação dos mercados consumidores internos e a integração da nação (construção de uma nacionalidade), por meio do que foi denominado de nacional-desenvolvimentismo do Plano de Metas. Nesse contexto, abordase a concepção urbanística de Brasília de forma a consolidar um entendimento dos preceitos que marcaram o projeto urbanístico da nova capital e aqueles que acabaram por influenciar todo o processo de formação do aglomerado urbano. A partir dessas duas abordagens, observa-se a ação do Estado na implantação da capital federal desde 1955 a 2005, tendo em vista três panoramas: o fundiário, o habitacional e do planejamento urbano. Ao fim desse trabalho, após observação da formação e evolução urbana da cidade de Brasília que foi implantada dentro de uma política nacional de desenvolvimento, faz-se uma análise do planejamento urbano moderno de Brasília sob a ótica da interpretação de pensadores da formação da sociedade brasileira e do Estado brasileiro. 


\section{ABSTRACT}

This work aims to observe the path of the deployment of modernist urban planning in Brasilia and its results. In another words, view the result of implementing a model of modern urban planning, more suitable for industrialized countries, in a society that, according to Francisco de Oliveira, combines the modern with late. For this, the choice was to do first is a reading of Brasilia as object of a national policy aimed at the expansion of domestic consumer markets and the integration of the nation (construction of a nationality), by means of what was called the national development of the "Plano de Metas". In that context, it looks to the urban design of Brasilia in order to build an understanding of the precepts which marked the urban design of the new capital and those who ultimately influence the whole process of formation of the urban agglomeration. From these two approaches, analyses the action of the State in the implementation of the federal capital since 1955 to 2005 with regard to three views: the land, the housing and urban planning. After this work, after observation of the formation and evolution of urban city of Brasilia which was established within a national policy for development, it is an analysis of modern urban planning of Brasilia from the perspective of the interpretation of theoreticians about the Brazil's society and the Brazilian state. 


\section{LISTA SIGLAS}

BNDE - Banco Nacional de Desenvolvimento

BNH - Banco Nacional de Habitação

CEI - Campanha de Erradicação de Invasões

CIAM - Congrés Internacionaux du Architecture Moderne (Congresso Internacional de Arquitetura Moderna)

CODEBRÁS - Coordenação do Desenvolvimento de Brasília

CODEPLAN - Companhia de Desenvolvimento de Planejamento

CODHAB - Companhia de Desenvolvimento Habitacional

CSNHP - Comissão de Supervisão de Núcleos Habitacionais Provisórios

DASP - Departamento de Administração do Serviço Público

DFSP - Departamento Federal de Segurança Pública

DRPB - Departamento Regional de Polícia de Brasília

DTA - Departamento de Terras e Agricultura

EPCT - Estrada Parque Contorno

EPIA - Estrada Parque Indústria e Abastecimento

EPTG - Estrada Parque Taguatinga

FRHB - Fundo Rotativo Habitacional de Brasília

FUB - Fundação Universidade de Brasília

GDF - Governo do Distrito Federal

GEB - Guarda Especial de Brasília da NOVACAP

GEMUD - Grupo Executivo da Complementação da Mudança de Órgãos da Administração Federal para Brasília

GEPAFI - Grupo Executivo Para Assentamento de Favelas e Invasões.

GRN - Guarda Rural da NOVACAP

GTB - Grupo de Trabalho de Brasília 
INIC - Instituto Nacional de Imigração e Colonização

IAP - Instituto(s) de Aposentadoria e Pensão

IAPB - Instituto de Aposentadoria e Pensões dos Bancários

IAPC - Instituto de Aposentadoria e Pensões dos Comerciários

IAPETEC - Instituto de Aposentadoria e Pensões dos Empregados em Transportes e Cargas

IAPI - Instituto de Aposentadoria e Pensões dos Industriários

IAPM - Instituto de Aposentadoria e Pensões dos Marítimos

IBGE - Instituto Brasileiro de Geografia e Estatísticas

IDHAB - Instituto de Desenvolvimento Habitacional de Brasília

IPASE - Instituto de Previdência e Aposentadoria do Servidor Público.

IPDF - Instituto de Planejamento Territorial do Distrito Federal

NOVACAP - Companhia Urbanizadora da Nova Capital

PAPE - Programa de Atendimento Populacional de Emergência

PLANAHAP - Plano Nacional de Habitação Popular

PPB - Plano Piloto de Brasília

PROMORAR - Programa de Erradicação da Subhabitação

RECON - Refinanciamento do Consumidor de Materiais de Construção

SBPE - Sistema Brasileiro de Poupança e Empréstimo

SEDUH - Secretaria de Estado de Desenvolvimento Urbano e Habitação

SEDUMA - Secretaria de Estado de Desenvolvimento Urbano e Meio Ambiente

SHEB - Sociedade Habitações Econômicas de Brasília

SHIS - Sociedade de Habitação de Interesse Social

TERRACAP - Companhia Imobiliária de Brasília

UNESCO - Organização das Nações Unidas para a Educação, a Ciência e a Cultura USER - Unidade Sócio-Econômica Rural 


\section{LISTA DE MAPAS}

MAPA I Áreas marcadas pela Missão Cruls, pelo Relatório Belcher e a área definitiva do Distrito Federal com os respectivos sítios estudados pela empresa Donald Belcher \& Associates.

MAPA II Mapa da situação fundiária do Distrito Federal, com os limites das antigas fazendas mapeadas pelo Cadastro Rural de Imóveis Primitivos do Novo Distrito Federal e com os antigos limites municipais 64

MAPA III Evolução urbana do Distrito Federal 84

\section{LISTA DE FIGURAS}

FIGURA I Proposta Traçado de subúrbio Linear para Subúribio de Madri. de Arturo Soria y Mata $\quad 55$

FIGURA II Projeto de Lúcio Costa apresentado para o concurso do Plano Piloto de

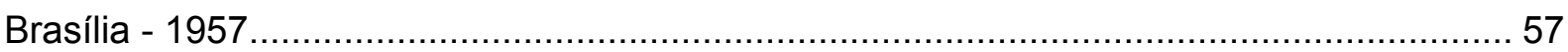

FIGURA III Centro de Abastecimento de Taguatinga .................................................... 110

FIGURA IV Remoção de barracos na Vila Planalto .................................................... 115

FIGURA V Casas construídas pela SHIS em Samambaia ………………………….... 118 


\section{LISTA DE TABELAS}

TABELA I. Quantidade de áreas desapropriadas pela NOVACAP com escritura pública definitiva com respectivos valores e percentual, no período de 1960 a 1965, e incidências no percentual geral de terras adquiridas até 1965, consideradas as desapropriações feitas pela Comissão de Cooperação goiana (1955-58).

TABELA II. Quantidade de áreas desapropriadas pela Comissão de Cooperação para Mudança da Nova Capital, com escritura pública com respectivos valores e percentual, no período de 1955 a 1958, e incidências no percentual geral de terras adquiridas até 1965, consideradas as desapropriações da NOVACAP (1960-65).

TABELA III. Quantidade de unidades habitacionais produzidas pelas setores público e privado entre o período de 1966 a 1974.

TABELA IV. Investimentos dos IAP em Brasília (total acumulado até 31/12/1965) ${ }^{1}$ em unidades residenciais e em imóveis para próprio funcionamento.

93

TABELA V. Quantidade de unidades habitacionais produzidas pelos setores público e privado entre 1964 e 1969

TABELA VI. Quantidade de Unidades Habitacionais produzidas pela Sociedade de Habitaçoes de Interesse Social - SHIS, por período de gestão administrativa, segundo tipo, durante o período de 1963 a 2005 116

TABELA VII. Quantidade de Unidades Habitacionais produzidas (casas e apartamentos), e recursos investidos de acordo com a o órgão estatal e gestão administrativa no período de 1966 a 1991. Valores atualizados a 31/12/2007 pelo INCC-FGV (R\$ 1.000,00). 119

TABELA VIII. População Urbana, segundo o motivo da última mudança de residência para a atual Região Administrativa - Distrito Federal - 2004. 123

TABELA IX. Parcelamentos considerados "informais" implantados ou não, de acordo com o período de levantamento oficial do Governo do Distrito Federal. 


\section{SUMÁRIO}

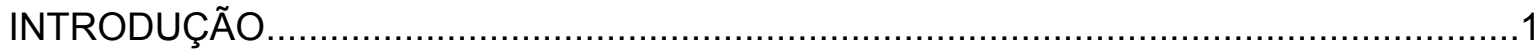

CAPÍTULO 1 - Brasília, a nova capital: nacionalidade e desenvolvimento .......................6

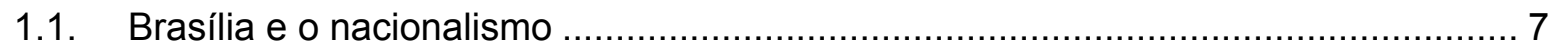

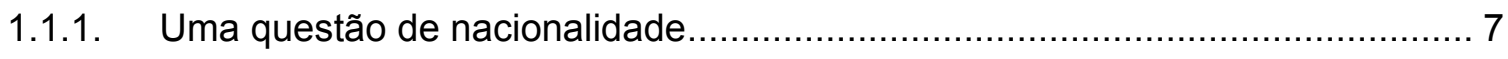

1.1.2. A expressão do desenvolvimento …...................................................... 19

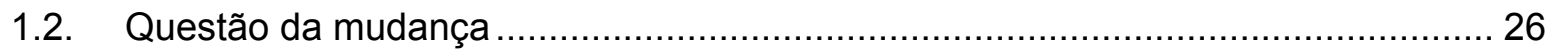

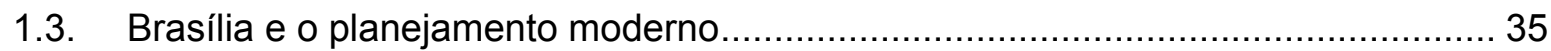

1.3.1. Os CIAM e os preceitos da Carta de Atenas ............................................. 37

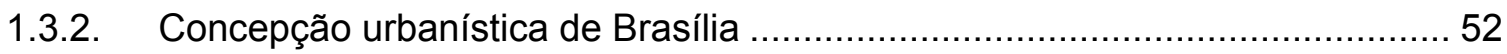

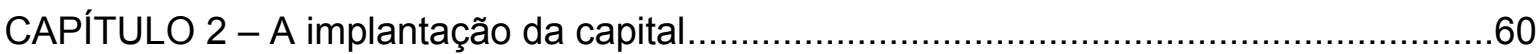

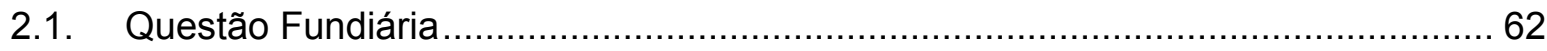

2.1.1. Aquisição de terras e o mito da terra pública ................................................ 66

2.1.2. Comissão de Cooperação para a Mudança da Nova Capital .......................... 73

2.2. A construção do espaço da nova capital.......................................................... 79

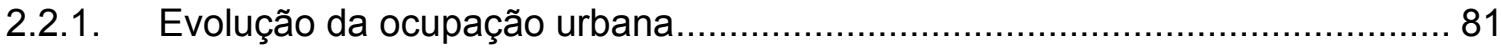

2.2.2. A construção do Plano Piloto e o mercado da construção civil. ....................... 91

2.2.3. As cidades satélites e o controle urbano: a questão da habitação ................. 102

2.2.4. Os parcelamentos do solo por particulares............................................. 126

CAPÍTULO 3 - Brasília e a Formação Nacional: as contradições entre o Planejamento Urbano Modernista e a Sociedade Brasileira ..................................................................133

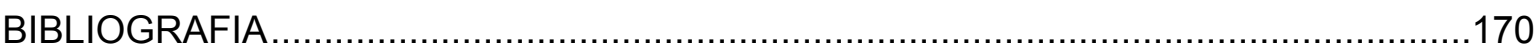

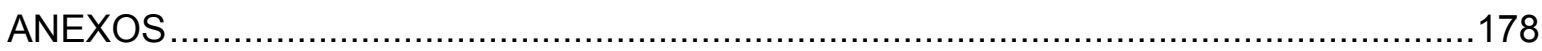




\section{INTRODUÇÃO}

É na periferia do "capitalismo brasileiro"1 da década de 50 que se concretiza um dos maiores empreendimentos nacionais, Brasília, que é implantada no centro geográfico do país como sendo a síntese de uma política pública nacional, a qual visava ampliar os mercados consumidores internos exatamente pela inflexão econômica que procurava marcar².

Fora do eixo central representado pelas cidades litorâneas e fora do eixo mais desenvolvido do país, a região Sudeste, sintetizava o discurso nacional-desenvolvimentista de Juscelino Kubitschek e Ihe dava uma cara concreta.

É inegável hoje, que a força econômica da região Centro-Oeste não prescinde da capital federal. É ela uma componente chave para explicar o aumento da participação econômica e da população dessa região na escala nacional.

Brasília pode ser vista como uma mudança concreta na matriz dos investimentos econômicos do Estado brasileiro que perduravam desde os períodos coloniais, de maneira a reorientar, inclusive, os investimentos privados. Não se pode afirmar que de fato isso tenha ocorrido na proporção que era manifestada no discurso nacional-desenvolvimentista juscelinista, que pretendia ao reorientar a economia nacional para o interior do país a concretização da auto-suficiência. Mas com certeza provocou transformações consideráveis, na forma de observar o interior do país como fronteira e mercado consumidor.

Não é intenção desse trabalho então, mensurar o resultado de uma iniciativa estatal como a transferência da capital na economia do país. Contudo, investimentos estatais ${ }^{3}$ de tal porte

\footnotetext{
${ }^{1}$ A expressão busca marcar a discussão que segue neste trabalho quanto à posição tanto geográfica como econômica da região que se implanta a nova capital federal. Pois na forma capitalista do modelo brasileiro, ele por si só já periférico ao sistema capitalista, e no discurso que associa Brasília ao desenvolvimento nacional, há uma busca interpretativa de apresentar o processo como a redenção dos territórios do interior. (discurso nacional-desenvolvimentista de JK)

${ }^{2}$ Ver MOREIRA, Vânia Maria Losada - Brasília a construção de uma nacionalidade, e sob o aspecto dos mercados consumidores internos ver SAMPAIO, Plínio de Arruda - O impasse da formação nacional in: FIORI, José Luiz - Estados e moedas, 2000

${ }^{3}$ Aqui se procura demonstrar que há diferença entre o público e o estatal. No segundo caso, está se
} 
sempre são acompanhados de um conjunto de interesses, privados e públicos, que se manifestam das mais variadas formas, e a apropriação desses no contexto da urbanização e construção de Brasília serão observados por meio das ações para aquisição de terras e da evolução do espaço urbano da nova capital federal, tendo em vista a ação do Estado.

No contexto da política, as análises serão feitas buscando respostas a algumas indagações a respeito do processo, como, por exemplo, foi possível a mudança da capital para o Centro-Oeste com tanta velocidade? Como uma decisão dessa magnitude, que interfere fortemente na própria relação do Estado com a sociedade, modificando o panorama geográfico do poder, pôde ser tomada?

Nenhuma decisão desse porte ocorre por um simples cumprimento de dispositivo legal. A transferência da capital para o interior do país, mesmo sendo um tópico, um artigo recorrente nas constituições republicanas durante 70 anos pós-colônia portuguesa, não deve ser interpretada como se fosse o mero cumprimento da carta magna da nação.

Arrisca-se em afirmar que a nova capital federal se constitui como um fato que contribuiu com a atual materialidade do Estado moderno brasileiro, que vinha sendo desenhado a partir de Vargas, e as relações e pactos necessários para sua existência. Mas, o que isso tem a ver com o processo de formação e evolução de Brasília? Foi, então, resultado das alianças necessárias para o cumprimento do Plano de Metas de JK? Em que tipo de sociedade se forma esse novo Estado e quais seus efeitos?

A estrutura dessa dissertação ora apresentada, tem como ponto de partida o entendimento da questão da construção da nacionalidade e como Brasília se inseriu nessa política de Estado. Como se inseriu na proposição de reestruturação econômica nacional sendo a própria forma concreta do desenvolvimento, da modernidade, que no campo da arquitetura e urbanismo se fazia por meio do movimento moderno, tendo no Congrés Internacionaux du Architecture Moderne - CIAM (Congresso Internacional de Arquitetura Moderna), uma referência importantíssima.

Num segundo momento, analisa-se o discurso e ações por trás dessas e outras questões que vão se formulando, no decorrer da observação do processo de concretização do espaço urbano do Distrito Federal, provocando também indagações sobre o planejamento urbano moderno no Brasil.

referindo a investimentos do Estado para o Estado, para a garantia de sua materialidade no que concerne a que denominado de "máquina", ou nos termos de Althusser dos seus "Aparelhos". 
Percebe-se que o planejamento urbano moderno no Brasil não representou uma ação que desse conta das disparidades sociais e econômicas nas cidades brasileiras, apesar do caráter transformador social presentes nos preceitos do urbanismo moderno, ao qual o projeto do Plano Piloto de Lúcio Costa se filiava, preconizado pelos arquitetos e urbanistas influenciados por diversos pensamentos modernistas, com maior destaque ao oriundo do CIAM.

A crítica é ao planejamento urbano moderno e à atuação do Estado brasileiro quanto às políticas públicas urbanas tendo em vista a sociedade na qual se implanta.

Brasília é o objeto de observação dessa crítica.

É a partir do objeto que se chega a uma hipótese sobre o Estado, na qual a segregação é elemento constituinte de uma ação que se apóia em um discurso sobre a degradação. Este último entra como elemento de uma argumentação ideologicamente construída, que estabelece a maneira pela qual ocorre, ou deve ocorrer quando for o caso, a apropriação dos espaços públicos e privados para a reprodução das relações necessárias ao "capitalismo brasileiro".

Segundo Nicos Poulantzas ${ }^{4}$, na tradição de Althusser, ao Estado é atribuída a função de garantir a reprodução das condições de existência e das relações necessárias para a manutenção de uma determinada sociedade.

O capitalismo dos trópicos brasileiro que pressupõe a precarização das relações de produção, para auferir o máximo ganho, se aproveitou de um ideário de planejamento moderno o qual propiciou aqui, as mais fantásticas armas de segregação e precarização, possibilitando no próprio desenvolvimento da década de 70 , o maior crescimento mundial do $\mathrm{PIB}$, sem a redistribuição das riquezas e diminuição da pobreza.

No caso de Brasília a própria condição desencontrada da situação fundiária é um desses fatores. O mito que se fazia do monopólio das terras pelo Estado como forma de controle e garantia de acesso a toda sociedade e redistribuição de renda aí se desfaz. Já que a forma econômica brasileira não consegue romper com elementos coloniais pré-existentes no Brasil, sendo o regime de terras um dos mais representativos.

Para Ricardo Faret

"Os fundamentos das políticas urbano-territorias, como por exemplo, daquela que

\footnotetext{
${ }^{4}$ POULANTZAS, Nicos. O Estado, o poder e o socialismo. São Paulo: Paz e Terra, 2000.
} 
resultou na implantação de Brasília, devem, assim, ser identificadas a partir de momentos históricos e políticos nos quais as concepções territoriais de planejamento emergiam dentro do quadro de formação social do Brasil'

É daí que se observou no decorrer da pesquisa a necessidade de se incorporar um outro viés de análise, um outro conjunto interpretativo sobre a formação social brasileira e o Estado brasileiro, recorrendo-se a pensadores como Celso Furtado, Florestan Fernandes e Caio Prado Jr, que sob a ótica de Plínio de Arruda Jr, contribuem com o entendimento do Brasil. De Francisco Maria Cavalcanti de Oliveira, ou Chico de Oliveira, é usada sua chave síntese presente na "Crítica à Razão Dualista" e mais precisamente em o "Ornitorrinco"

E a estes pensadores agrupou-se dois outros que dão ênfase ao Estado brasileiro: Raymundo Faoro, na leitura da formação do Estado patrimonialista de "Os Donos do Poder" e Wanderley Guilherme dos Santos, com sua interpretação sobre a construção da materialidade do Estado moderno brasileiro, autor que tem buscado análise mais profunda da constituição material do Estado brasileiro, com uma competente análise de dados e processos.

É, então, ao fim desse desenvolvimento citado, que se busca uma explicação da forma atual do espaço urbano de Brasília, e suas correspondências sociais.

As relações que por ventura se buscam para uma visão interpretativa dessa evolução urbana e seu resultado, não se pretendem totalizadoras ou finitas, tomando o cuidado ao qual José de Souza Martins se refere ao fazer a crítica da forma pela qual o educador popular por vezes se orienta, que é extensível ao pesquisador, as quais deveriam derivar "os conceitos da práxis," mas não ao contrário, ou seja, tender a "fazer da práxis a realização dos conceitos", e assim num esforço vão desenvolver "uma peleja de palavras e conceitos, uma luta vazia em torno de significados sem raiz na prática concreta dos que lutam pela vida, em nome dos quais, aliás, procuram falar. Sua ação tende a se reduzir ao discurso que não se nutre do vivido."

Em outras palavras, tendo em mente a base teórica conceitual da qual esse trabalho procura se filiar, não será por que se dará a análise do objeto, mas o oposto, observado o objeto e a praxis ligada a ele será possível "desmascarar" as idéias por trás das realizações.

\footnotetext{
${ }^{5}$ FARET, Ricardo - O estado, a questão territorial e as bases da implantação de Brasília in: Brasília, ideologia e realidade: Espaço urbano em questão. Editora Projeto: São Paulo 1985 pg 20

${ }^{6}$ MARTINS, José de Souza - A exclusão Social e a nova desigualdade. Paulus São Paulo, 1997, pg 9.
} 
Não será a partir da teoria a observação, mas da práxis e do discurso.

O que interessa a Martins é a simples e dificílima tarefa de descobrir dos aspectos problemáticos da realidade social, "os significados ocultos e ocultados, os mecanismos invisíveis da produção e reprodução da miséria, do sofrimento e das privações." e o mais importante, descobrir, descortinar, as contradições e fragilidades. 


\section{CAPÍTULO 1 - Brasília, a nova capital: nacionalidade e desenvolvimento}

Comumente se aborda a construção de Brasília como um ato de insistência histórica, ou de determinados grupos de interesse, tendo sempre referências às questões do espaço nacional a ser ocupado, eventos e imagens históricas, entre muitas outras posições.

Mas, a construção da capital federal no interior do país se apresenta como o resultado de um dos discursos mais bem articulados do Estado moderno. Sob a regência do então presidente da república Juscelino Kubitschek a idéia de Brasília transcendeu a questão da estratégia de segurança do núcleo do poder e se transformou na forma de materialização de uma questão de nacionalidade e desenvolvimento nacional.

Partindo do interior do Estado, esse discurso dava conta da necessidade de conhecer o território e todo o povo do interior para se concretizar a nação brasileira, sendo necessária a disseminação do desenvolvimento como maneira de reconhecimento e distribuição das benesses do mundo moderno que até então estava segregado às regiões litorâneas e em específico ao Sudeste.

Para Juscelino Kubitschek, Brasília era síntese desse ímpeto nacionalista e desenvolvimentista. O Estado lançado ao seu centro geográfico e tomando posse do território ainda desconhecido do interior.

Diferentemente da visão varguista, onde era no interior que se encontraria as condições materiais para a construção da nova sociedade e onde se encontrariam as matérias primas necessárias para forjar as armas, bélicas e econômicas, para a defesa do Brasil-nação, no governo JK, o interior também representava a ampliação dos mercados consumidores o que atribuía aos investimentos nessa região outra característica: não se tratava apenas da exploração econômica, mas antes de tudo, da criação de um mercado consumidor interno visando à ampliação da economia.

Para outras interpretações, a nova capital servia também como uma questão de identidade nacional, na verdade, a identidade de uma sociedade que se queria renovar. É neste ponto que os mudancistas encontravam adeptos nas correntes sociológicas. Thomas Skidmore ${ }^{7}$ aponta que até os anos 50 os intelectuais brasileiros agonizavam sobre a questão da

\footnotetext{
${ }^{7}$ SKIDMORE, Thomas E. O Brasil visto de fora. Rio de Janeiro: Paz e Terra, 1994. Pg 71 a 98
} 
identidade nacional e sobre a formação do Brasil.

A nacionalidade que permeia o pensamento desenvolvimentista de Kubitschek, admite os "Brasis" dentro do Brasil, ou seja, a realidade multifacetada das regiões. A grande percepção do discurso para a criação de consenso está em reconhecer essas diferenças, ao mesmo tempo que busca oferecer a todas as regiões as mesmas condições encontradas nos centros litorâneos e do sudeste.

Para Miriam Limoeiro Cardoso, os principais elementos formadores do que interpreta como a ideologia do desenvolvimento no pensamento juscelinista, se relacionam da forma como aparece num esquema em que:

"O objetivo básico que o desenvolvimentismo propõe e para o qual faz convergirem todos os esforços compreende o desenvolvimento econômico e o bem-estar social. Não é esta, porém, a sua finalidade última, a qual, no entanto, julga não poder atingir a não ser por meio deles. O que fundamenta ideologicamente o próprio desenvolvimento econômico e social é a manutenção da ordem, a preservação da civilização cristã, em suma, a segurança do sistema. Esta aparece no desenvolvimentismo como a aspiração mais profunda, a meta que confere significado a todas as preocupações. É em torno dela que se constitui esta formulação político-ideológica. O próprio fim aparentemente considerado como o mais importante, o desenvolvimento do campo econômico, é posto a seu serviço, é o meio considerado indispensável, no caso dos países atrasados como o Brasil, para atingi-la. Porque na continuação da pobreza que este atraso contém, a aquela ordem se torna ameaçada."

\subsection{Brasília e o nacionalismo}

\subsubsection{Uma questão de nacionalidade}

A questão da nacionalidade, de um povo se perceber e ser percebido como integrante de uma única nação, mais especificamente como "um grupo de pessoas unidas por laços naturais e portanto eternos - pelo menos existente 'ab immemorabili' "', é ponto importante

\footnotetext{
${ }^{8}$ CARDOSO, Miriam Limoeiro. Ideologia do desenvolvimento - Brasil JK - JQ. Rio de Janeiro: Paz e Terra, 1977. p 209

${ }^{9}$ BOBBIO, Norberto, MATTTEUCCI, Nicola e PASQUINO, Gianfranco - Dicionário de Política p. 796
} 
para uma posição interpretativa que tem na construção da cidade-capital um momento único.

A nova capital fazia parte de uma idéia que tinha a pretensão de reorganizar o poder na forma de um Estado nacional moderno. A epopéia da construção da capital, motivada pelo governo de Juscelino Kubitschek, buscava prenunciar a transposição do Brasil considerado arcaico para um Brasil moderno; buscava integrar Brasis em um único Brasil.

Sob esse prisma, a discussão sobre a construção da nação, da consolidação do território e integração do povo que nele habita, Brasília representa um objeto único de análise.

O ideário e os discursos de apoio à mudança da capital basearam-se sempre na construção de uma nacionalidade que não prescindia de um povo, mas necessitava reconhecê-lo, e onde a interiorização do Estado e suas estruturas seriam fundamentais para esse empreendimento de unificação e conhecimento desse grupo de pessoas do interior do país.

A interiorização era uma posição interpretativa na conciliação desse pensamento com a realidade das diferenças regionais encontradas. O nacional-desenvolvimentismo do ideário juscelinista tinha sua tônica marcada nesse ponto.

A nacionalidade do Brasil estava em conhecer e reconhecer que o país devia voltar os olhos, naquele momento, para o Brasil do interior, em contraposição às centenas de anos de atenção e investimentos que haviam sido destinados ao Brasil do litoral, ao Brasil do sudeste.

Essa nacionalidade à qual é devida a idéia de construção da nação, como afirma Wanderley Guilherme dos Santos ${ }^{10}$, deriva de três crises comuns às sociedades e que no Brasil ocorreram ao mesmo tempo, sendo as crises de integração nacional (identidade), de participação política e a de redistribuição. Segundo Santos, o enfrentamento dessas crises em países capitalistas avançados, ocorre de maneira sucessiva, possibilitando que a experiência na superação de cada uma alimente o processo de resolução da seguinte, numa pedagogia processual. Essa discussão será abordada mais adiante. É no período Vargas que se inicia esse enfrentamento, por meio de suas ações na área econômica e social ao buscar reforçar uma nova estrutura econômica e urbana.

O ideário de JK busca uma solução para essa tarefa de forma única em um conjunto de ações do Estado que se concretizariam no Plano de Metas, no discurso dos "50 anos em 5",

\footnotetext{
${ }^{10}$ SANTOS, Wanderley Guilherme dos. O ex-Leviatã brasileiro: do voto disperso ao clientelismo concentrado, 2006. p.41
} 
na industrialização baseada na substituição por importações ${ }^{11}$. É na materialização da capital federal no interior do país que, não só de forma simbólica, mas social, política e econômica, enfatiza sua política.

A orientação e planejamento econômico adotado por Kubitschek eram heranças da era varguista, quando se iniciou o processo das crises citadas na interpretação de Santos. Juscelino Kubitschek adota algumas estratégias administrativas de Vargas em sua segunda estada no governo ao criar estruturas para-estatais para por em prática o processo de um desenvolvimento capitalista planejado, como o Conselho de Desenvolvimento Econômico, e, no caso concreto de Brasília, a Companhia Urbanizadora da Nova capital - NOVACAP ligada diretamente à presidência. Ou mesmo vincular estruturas já existentes, mas estratégicas para a viabilização do Plano, como o BNDE - Banco Nacional de Desenvolvimento Econômico.

É nos governos de Vargas que a idéia de um desenvolvimento planejado a partir do Estado ganha forma. Mais precisamente, é a partir dele que a construção de um desenvolvimento econômico planejado pelo Estado, buscando a nacionalidade ${ }^{12}$, ganha força como idéia. Esse processo de planejamento já estava sendo esboçado, segundo Vânia Moreira ${ }^{13}$, nos trabalhos apresentados pela Missão Cooke (1942-43), pela Missão Abbink (1948) e pela Comissão Mista Brasil-Estados Unidos (1951-53), resultado da cooperação norte-americana e que somadas ao Relatório Simonsen e o Plano SALTE do governo Dutra, sendo todos eles fundamentais para a execução do Plano de Metas de JK.

Para Guido Mantega ${ }^{14}$, dois outros trabalhos são primordiais: os estudos da Comissão de Estudos Permanentes da América Latina - CEPAL, e os estudos do CEPAL - BNDE.

A nacionalidade expressa de JK está na afirmação do interior do país e seu desenvolvimento, primordiais para a constituição de uma idéia de nação. A integração do território e o desenvolvimento econômico são parte desse ideário. O Estado nacional moderno de JK é um Estado, antes de tudo, que deve conhecer todo o território e ter

\footnotetext{
${ }^{11}$ Modelo analítico desenvolvido por Celso Furtado entre outros. Caio Prado Jr, faz uma brilhante análise com relação a interferência desse modelo econômico na vida social brasileira.

${ }^{12} \mathrm{Na}$ vertente varguista o discurso de nacionalidade é resultado do discurso do nacionalismo.

${ }^{13}$ MOREIRA, Vânia Maria Losada. Brasília: A construção da nacionalidade: um meio para muitos fins (1956-1961). Vitória: EDUFES, 1998.
}

${ }^{14}$ MANTEGA, Guido. A Economia Política Brasileira. São Paulo: Editora Vozes, 1984 
informações concretas sobre este. Em seu entendimento do cenário da década de 50, essas condições não haviam sido alcançadas, o governo não possuía informações suficientes para uma ação transformadora já que desconhecia esse interior. Na proposição política a qual se filiava, esse Estado deveria ser reestruturado para existir em consonância com a totalidade da sociedade brasileira do litoral e do interior.

Num entendimento importante que baliza a própria natureza da relação da sociedade com o Estado, quanto à nacionalidade cita-se que, para Max Weber, "O Estado só pode existir, portanto, sob condição de que homens dominados se submetam à autoridade continuamente reivindicada pelos dominadores." 15 , os homens dominados, portanto sujeitos ${ }^{16}$ na definição de Emmanuel Kant, dos quais a proposta nacional-desenvolvimentista juscelinista quer conquistar, são aqueles do interior dominados pelas oligarquias do interior, oligarquias rurais formada basicamente dos grupos ruralistas.

Recai assim a dúvida: em que condições e por que esses indivíduos por fim "aceitam" a sujeição? A resposta política de Juscelino Kubitschek para seu nacionaldesenvolvimentismo ser implantado resultou em uma associação com os setores rurais.

Há certa consonância com a resposta weberiana a esse tema, a qual aponta para três razões possíveis para a existência dessa relação, as quais sejam: o poder tradicional sancionado pela tradição, pelos costumes santificados ou até pelo hábito; o carisma resultado de dons pessoais onde a devoção é dada a alguém considerado digno por seu prodígio que fazem dele um chefe a ser seguido; e a legalidade resultante de um estatuto legal respeitado, fundado em regras racionais. Nenhuma dessas razões deveria prescindir de legitimidade.

Weber acreditava que o único Estado capaz de lidar com a nova estrutura social que despontava era aquele baseado na racionalidade, e por isso, a terceira razão apontada por ele é a única que poderia ser amplamente aceita, em qualquer tempo, já que garantiria uma estabilidade por meio da legalidade e da burocracia a ser constituída para mantê-la, descartando outros tipos de organizações que se baseavam no poder patriarcal e patrimonial, "(...) e insisto muito particularmente no Estado burocrático por ser ele o que

\footnotetext{
${ }^{15}$ WEBER, Max - Política como vocação in: Ciência e Política duas vocações. Cultrix. São Paulo, pg 57

${ }^{16}$ KONDER, Leandro. A questão da Ideologia. São Paulo: Companhia das Letras, 2002.
} 
melhor caracteriza o desenvolvimento racional do Estado moderno."17

Tem-se então, partindo dessa observação, uma compreensão geral apontada por Max Weber, na qual pode-se fazer uma reflexão sobre o contexto de JK. Para assegurar a direção do Estado se associa ao poder tradicional patriarcal e patrimonial, em contradição à postura weberiana. Juscelino não representava, a priori, esse poder tradicional, não era membro de uma elite oligárquica rural, e por isso seu vínculo com ela visa à viabilização de sua política.

Além dessa aliança frágil, que na verdade se consolida após sua chegada ao poder, observa-se a concretização da segunda e terceira razão, exposta por Weber, onde o carisma de líder o levou à presidência da república de forma legitima, seguindo o estatuto legal da nação. Essa interpretação põe a questão da marca que Juscelino busca assumir como integrador nacional e homem da modernidade em discussão, já que, buscando fazer com que seu programa de governo obtivesse êxito tende a fazer associações com segmentos do Brasil que procura se afastar do Brasil visto como arcaico.

Mas, como Ricardo L. Faret coloca em $O$ estado, a questão territorial e as bases da implantação de Brasília ${ }^{18}$, outra indagação mais próxima dos urbanistas se faz: o porquê construir uma nova capital e não, por exemplo, um centro urbano pura e simplesmente, ou reforçar um já existente, ou mesmo outra ação empreendedora?

Tanto este autor como também para Benício Schmidt, em seu artigo Brasília como centro político, em mesma publicação, entendem que a questão que se coloca é que a construção do centro político nacional foi "crucial para a configuração estatal e territorial e por meio da qual a sociedade civil trata de regulamentar 'as relações intra-societais e inter-grupais' no tratamento dos chamados problemas de integração derivados da divisão do trabalho social."19

Ou seja, como Ricardo Faret e Benício Schmidt acabam por definir, é uma posição quanto a uma política territorial que se constitui "num meio de harmonizar o complexo jogo de interação entre economia e política de uma determinada formação social histórica", sendo,

\footnotetext{
${ }^{17}$ WEBER, 2004 , pg 61

${ }^{18}$ FARET, Ricardo L. O Estado, a questão territorial e as bases da implantação de Brasília in: PAVIANI, Aldo (org). Brasília, ideologia e realidade: Espaço urbano em questão. São Paulo: Projeto, 1981 p. 19 a 25

${ }^{19}$ SCHMIDT, Benício. O centro in: PAVIANI, Aldo Op.cit.
} 
portanto, "passo lógico dentro de processo de acumulação que impõe determinados padrões de divisão social e espacial do trabalho".

No entendimento de Faret, Brasília é uma ação que ocorre em momento específico, determinada por um complexo de fatores em que se pode verificar uma ação deliberada do Estado em eliminar empecilhos à plena socialização do espaço. Empecilhos estes decorrentes de ações anteriores do Estado que imobilizaram e isolaram o Brasil do interior. Entende-se esse isolamento, dessa parte do país, quanto à inserção das relações de produção e investimentos que ocorriam nas regiões litorâneas e no sudeste.

O panorama nacional à época é identificado e expresso por Faret da seguinte forma:

"A estrutura territorial resultante foi determinada pelas necessidades de exploração colonial e caracterizava-se por umas poucas regiões agrícolas e cidades costeiras. Ligadas diretamente à Europa, elas se constituíam, de fato, mais em verdadeiros enclaves do que em sistemas organicamente estruturados. Assim, regiões estabeleceram vínculos estreitos com os pólos do sistema capitalista e permaneciam isoladas uma das outras. ${ }^{20}$

O objetivo do nacional-desenvolvimentismo defendido por JK buscava alterar essa lógica e a impressão e o desejo de que Brasília se tornasse o ponto de inflexão na formação social brasileira representa a mais clara ideologia ${ }^{21}$ do modernismo brasileiro, e de alguns setores nacionalistas.

O fato é que forças e interesses sociais seculares, representados pela elite oligárquica rural haviam se apoderado da própria concepção de mudança da capital. Moreira levanta essa questão ao relacionar o ruralismo ao desenvolvimentismo. Para esta autora

"As relações relativamente amistosas entre governo e setores tradicionais são geralmente explicadas recorrendo-se à perspicácia política do Presidente que soube evitar atritos com o setor rural ao implementar o Plano de Metas ${ }^{22}$. O governo não

\footnotetext{
${ }^{20}$ FARET, Op.Cit

${ }^{21}$ Ideologia aqui expressa como sendo a transposição das idéias ao mundo real, sem às claras e necessárias considerações quanto sua materialização e locus de realização, mascarando o real por meio de discurso articulado, competente e lacunar. Refere-se ao preceito marxista aqui. Ver em MARX, Karl. Ideologia Alemã. Também CHAUì, Marilena, O que é Ideologia, e em Cultura e Democracia; EAGLETON, Terry. Ideologia; KONDER, Leandro. A questão da Ideologia

${ }^{22}$ Exemplo disso pode ser verificado em BENEVIDES, Maria Victória de Mesquita. O governo Kubitschek. Desenvolvimento econômico e estabilidade política, 3ed. Rio de Janeiro: Paz e Terra,
} 
interferiu, deste modo, em dois centros de interesses oligárquicos: o regime fundiário e a política clientelista. Esta permaneceu concomitante à administração paralela."

Assim, na leitura de Moreira, o setor agrário, representado pelos ruralistas, fez parte da base de sustentação e estabilização do governo JK, reafirmando a interpretação anteriormente feita com base em Weber, já que este, ao evitar a realização de uma discussão maior quanto à questão agrária e à reforma administrativa tornou seu discurso viável de ser incorporado pelo setor.

É fato de se notar que em nenhuma das 31 metas de seu Plano exista qualquer referência ou evidência que estabeleça a realização da primeira questão, a agrária, como forma de socialização do interior, de maneira que assegura o status fundiário vigente de sua época. Este fato é importante na observação da própria ação de desapropriação do Distrito Federal, o qual será tratado adiante, pois é parte integrante e explicativa da atual forma de ocupação do território da capital.

Não obstante a isso, a própria importância que esse setor, mais especificamente a elite oligárquica representada politicamente no Parlamento, dava a si no contexto de dominação nacional, contribuía para que uma política de interiorização lhe fosse benquista. O interior do país era seu território de domínio político e econômico e era nele que o Plano de Metas iria atuar de forma decisiva.

"Foram justamente os ruralistas que discutiram o processo de desenvolvimento brasileiro a partir da perspectiva exclusiva da elite proprietária do campo e da cidade. $O$ projeto social defendido pelo setor, e que esteve subjacente ao debate sobre a construção da cidade, vislumbrava um caminho de desenvolvimento 'pacífico' e integrado entre capital industrial e agromercantil. Do ponto de vista ruralista, a nova capital permitiria a expansão dos dois setores, não interferiria na propriedade fundiária e asseguraria à elite governante, composta sobretudo por representante rurais, a 'paz' necessária ao exercício do poder ${ }^{\text {"23 }}$

Essa interpretação sobre a influência e decisão da elite proprietária rural é pouco observada, mas compõe e contribui para uma leitura analítica interessante sobre a discussão do desenvolvimentismo.

Não há como negar a força do setor industrial na plataforma política e econômica do Plano de Metas, pois estava claro no discurso sua importância, mas é na lacuna do discurso do

1979.

${ }^{23}$ MOREIRA, 1998 p. 197 (grifo da autora) 
nacional desenvolvimentismo do programa de JK que se encontra o respaldo para a interpretação do interesse e apoio do grupo de proprietários rurais ao programa de industrialização. O setor considerado mais atrasado estava em compasso com o setor que procurava se modernizar o mais rápido possível, a conciliação de interesses é marcante. $O$ Plano de Metas então representa em partes importantes, um discurso lacunar ${ }^{24}$, onde o que não é dito é tão ou mais importante quanto aquilo que é dito. Nada é dito sobre a propriedade fundiária e às relações de trabalho no campo.

À elite fundiária interessava a ampliação da fronteira agrícola, sem que o regime de terras ou de propriedade sofresse alteração. Apesar dessas condições levantadas, não se pode negar o interesse sobre o processo de industrialização e a intenção de aumentar mercados consumidores. A própria transferência de estruturas administrativas federais para o interior representava uma mudança importante na reorganização econômica e política. Apresentava, com isso, clara intenção de mudança nas condições sociais via mercado consumidor.

A elite rural era (é) conservadora, o que the interessava naquele momento era a manutenção do status quo fortemente ligado à propriedade fundiária, e é nisso que se firma para reproduzir sua condição de existência enquanto grupo dominante, num pretenso novo contexto nacional de interiorização. Sua política é conciliadora, buscando limitar os avanços sociais que vinham a reboque do processo de industrialização, utilizando um discurso de apoio à mudança, em que de maneira ideológica se filiava, para garantir que toda a transformação pretendida fosse uma afirmação de permanência das relações e formas de produção. Portanto, a intenção era: tudo muda para que permaneça como está.

Essa mesma elite via como perigoso o processo de democratização no qual o país vinha se estruturando, e de certa forma o processo de urbanização brasileiro apresentava-se como uma situação incômoda, já que era visto como motivador do aumento da participação política e social. O Estado populista se fortalecia com esse viés. Brasília era uma medida que interessava pelo fator de ampliação de fronteiras e interiorização dos investimentos estatais a qual deveria ser conduzida, na visão dessa elite, pelos ruralistas a fim de não ferir seus interesses.

A capital deveria então marcar um pacto político: interesses industriais e agromercantis seriam respeitados e teriam seus espaços físicos marcados, mas na verdade, essa condição

\footnotetext{
${ }^{24}$ CHAUÍ, Marilena. Cultura e democracia: o discurso competente e outras falas $-11^{\text {a }}$ ed revista e ampliada - São Paulo: Cortez, 2006
} 
representava a própria contradição que vivenciavam, já que na fórmula econômica adotada desde Getúlio Vargas o setor agromercantil é que financiava a industrialização do país.

Há que se ressaltar que a vinculação política de JK com o interior e seu convívio com essa elite, provavelmente Ihe davam uma visão perspicaz quanto à agenda desse grupo e sua forma de atuação. Tanto UDN quanto PSD tinham base ruralista.

Não só o acordo com grupos dominantes era necessário, o consenso quanto à mudança foi arma poderosa do discurso nacionalista de JK.

Moreira aborda a questão do consenso em torno da criação de Brasília. Procura demonstrar que a criação de um imaginário consensual passa por admitir a construção secular de uma aspiração nacional por meio da descrição sumaria de eventos. É então por meio de uma historiografia de eventos que se constitui uma argumentação

"O mais notável destes recursos é o discurso linear e cronológico que insistentemente liga o ideal mudancista aos grandes marcos da evolução da política brasileira, consagrados pela historiografia tradicional. O ideário mudancista foi sistematicamente correlacionado com o processo emancipacionista, por meio dos inconfidentes mineiros e de José Bonifácio; com o ideário republicano, por meio dos constituintes de 1932; e com a democratização do País, por meio dos constituintes de 1946. O tema mudancista passou a figurar, deste modo, no roll dos 'fatos históricos' importantes. Ligava-se, aliás, os 'fatos' que marcaram o processo de formação do Brasil, enquanto nação independente, republicana e democrática. Por isso, nada mais 'natural' do que qualificar a construção de Brasília como uma 'aspiração nacional'”25

Essas interpretações, essas 'histórias de Brasília', tentavam caracterizar que a construção da Capital no Planalto Central era a concretização de um ideal secular resultado de uma aspiração nacional, de toda a nacionalidade, de toda a opinião pública. Esse discurso enfatiza que para a efetiva criação da nação brasileira se fazia inevitável a interiorização da capital. A Capital 'inaugura' o ponto sem volta da nacionalidade brasileira, democrática e republicana. Ou seja, "o momento de construção da cidade é simplesmente, o momento em que a 'consciência nacional' havia amadurecido por completo sobre a interiorização", como Moreira enfatiza.

O tempo demonstra que o espaço-sede criado, fruto de uma nacionalidade democrática, é para o governo e não para um tipo de regime, sua dinâmica físico-territorial não se restringe

\footnotetext{
${ }^{25}$ MOREIRA, Vânia Maria Losada. Brasília: A construção da nacionalidade: um meio para muitos fins (1956-1961). Vitória: EDUFES, 1998. p 59 (grifo da autora)
} 
a um tipo social determinado, isto é discurso ideológico que vincula o projeto modernista de Brasília a um tipo determinado de regime sem as devidas considerações.

Entretanto, também é discurso aquele que vincula a necessidade de Brasília ao processo de criação de uma nação moderna que seria inauguradora de uma nova realidade nacional, fundadora do Brasil moderno. Essa forma de discurso da nacionalidade é radiante, estando inserido no que Marilena Chauí marca como a própria ideologia, apresentada em um discurso competente já que é apresentada pela elite intelectual e política, e lacunar por nem tudo dizer.

Há uma necessidade tremenda de tornar a 'história de Brasília', em aistórica ${ }^{26}$. Uma história onde os únicos agentes são heróicos defensores de uma idéia. Uma relação que tem a ver com o governante e sua marca, seu registro efetivo e seus interesses, aos quais Brasília se vinculava como um dos pontos cruciais. O ideário desenvolvimentista, que aos poucos ganha contorno de ideologia numa leitura althusseriana ${ }^{27}$, fez uso desse discurso para se afirmar como chave para uma política nacional.

Moreira deixa aberta uma interpretação na qual a idéia de consenso e euforia são resultado de uma fetichização ${ }^{28}$ de Brasília, sendo que os setores que queriam a rápida mudança são os responsáveis por propagar o discurso como sendo um consenso histórico que transcende aquele período especifico, ou seja, a discussão secular, ou melhor, bi-secular, é o argumento de que se vale pela recorrência histórica, estando presente em eventos considerados "marcos históricos".

${ }^{26}$ Forma mais usual de anistórico. No dicionário Houaiss: "1. que não participa da história; 2 avesso, antagônico à história; anti-histórico."

${ }^{27}$ Um dos aspectos importantes na construção do raciocínio de Althusser é admitir que a possibilidade de uma teoria para a ideologia em geral, partindo de pressupostos já postos por Marx, que afirma que ideologia não tem história. Para Marx "a ideologia não tem história, uma vez que está fora dela, lá onde está a única história, a dos indivíduos concretos" (Marx, 1998 p.18), para Althusser ela não tem história pois "tem estruturas tais que fazem dela uma realidade não-histórica, isto é, omnihistórica, no sentido em que a estrutura e este funcionamento se apresentam na mesma forma imutável em toda história, no sentido em que o Manifesto define a história com a história da luta de classes, ou seja, a história das classes sociais".(Althusser, 1985)

${ }^{28}$ Ainda que não existisse como coisa física, como espaço socialmente construído (carrega aqui uma contradição em si), Brasília era resultado de uma construção imaterial de um trabalho social ainda não realizado, por uma sociedade moderna ainda não constituída, mas em formação de acordo com o nacional-desenvolvimentismo. Holston vê Brasília, sob esse aspecto, como forma utópica. 
Esses eventos são parte importante da argumentação que marca o discurso mudancista, já que se prestam a caracterizar a decisão da mudança como pertencente ao paradigma de independência e formação da nacionalidade brasileira. O discurso primeiramente articulado por uma necessidade de segurança dos governantes, dada uma visão estratégico-militar de estar o centro do poder distante do litoral, e por isso, menos vulnerável ao ataque estrangeiro, ganha novo contorno ao ser também vinculado ao discurso desenvolvimentista que pretende, por meio da interiorização da capital, a interiorização do desenvolvimento, o qual levaria à integração da nação.

Três são os princípios, ditos estratégicos, do discurso mudancista, articular as visões estratégico-militar, estratégico-econômica e estratégico-social. Geopolítica, economia nacional e desenvolvimento social.

E por isso dois níveis de discussão sobre o nacional desenvolvimento tomam a cena na política brasileira segundo Moreira: 1. Propaganda ideológica na qual Brasília é exemplo papável de desenvolvimento e modernidade; 2. Amplos debates nacionais em função de diferentes interesses e projetos sociais. Sendo assim resultado também de um debate político, onde o nacional-desenvolvimentismo teve sua vitória. Essa interpretação também está presente no trabalho de Marcelo Coelho, Brasília e a ideologia do nacionaldesenvolvimento.

Outra interpretação importante é a de Francisco Maria Cavalcanti de Oliveira (Chico de Oliveira), em seu artigo $A$ questão regional: a hegemonia inacabada onde faz uma síntese do que entende como o processo de unidade nacional.

"A unidade nacional será o resultado do processo de competição entre burguesias nascentes, de um lado, e, de outro, das alianças que elas conseguem estabelecer com uma burocracia imperial propriamente dita. Esse processo inclui a formação das principais instituições do próprio Império, no bojo da burocracia, inclusive Exército e Marinha, cujo papel extraordinário na organização da concorrência foi justamente romanceado - e ideologizado - pela epopéia da unidade nacional. Uma das burguesias nascentes sedia-se no Rio, é já a proprietária da cafeicultura em expansão advertência aos que podem (ou querem) ver neste ensaio uma catilinária bobamente antipaulista - e faz aliança com os negreiros os quais haviam transformado o Rio em principal praça comercial das peças d'África, uma das fontes da acumulação primitiva que pavimentam o caminho da expansão da cafeicultura, ao arrepio da naturalização do capital das interpretações de Caio Prado Jr. e Celso Furtado. ${ }^{29}$

${ }^{29}$ OLIVEIRA, Francisco M. C. A Questão Regional: A hegemonia inacabada. Revista de Estudos 
Sendo que mais à frente, em mesmo artigo, estabelece uma interpretação da hegemonia inacabada para explicar o que se produziu no contexto brasileiro, que a seu modo foi uma unidade nacional não finda.

"A hegemonia inacabada criou um monstro, que foi, durante muito tempo, uma aliança de interesses entre a burguesia industrial e oligarquias agrárias retrógradas. O famoso mistério do país que se industrializava sob a batuta de dois partidos de base rural $P S D$ e UDN - é esclarecido quando pensado de outra forma: tratou-se da aliança entre a burguesia industrial e poderosas e reacionárias oligarquias rurais, latifundiários para sermos mais precisos. Esse monstrengo deixou intacta a questão agrária, irresoluta a questão do mercado de trabalho no campo, com o que reiterava a própria questão agrária e, por extensão, também sem resolução a questão negra no coração da própria industrialização."

Essa observação sobre a hegemonia cabe na concepção do par Estado e sociedade civil como agentes interpenetrantes, presente nas considerações de Antônio Gramsci, e é idéia importante para o entendimento da questão da nacionalidade e o papel do consenso. Segundo Carlos Nelson Coutinho, é Gramsci que define um aspecto imprescindível da natureza do Estado, considerando que a ideologia é intrínseca a todo o pensamento e concepção de políticas ocidentais, que é por meio do consenso e da hegemonia que se criam as condições do Estado Nacional. A Teoria "ampliada" de Estado gramsciana, abarca a sociedade civil em seu contexto, incorporando assim à análise desse pensador, uma outra dimensão do Estado.

"[...] o conceito de sociedade civil como portadora material da figura social da hegemonia, como esfera de mediação entre a infra-estrutura econômica e o estado em sentido restrito. ${ }^{30}$

Pode-se perceber que no discurso nacional-desenvolvimentista do qual Brasília era uma expressão da construção da nacionalidade e do próprio desenvolvimento, essa tentativa da conquista da hegemonia, da sociedade civil era ponto importante.

Avançados. http://www.scielo.br/scielo.php?script=sci_arttext\&pid=S0103-40141993000200003. Acesso: 20 de dezembro de 2007.

${ }^{30}$ COUTINHO, Carlos Nelson - Gramsci: um estudo sobre seu pensamento político, p 121 


\subsubsection{A expressão do desenvolvimento}

No processo da economia política brasileira, o desenvolvimentismo foi um ideário econômico consensual e uma ideologia, a qual, como afirma Guido Mantega em $A$ Economia Política Brasileira, "empolgou boa parte da intelectualidade latino-americana nos anos 40 e 50, e se constituiu na bandeira de luta de um conjunto heterogêneo de forças sociais favoráveis à industrialização e à consolidação do desenvolvimento capitalista nos países de ponta desse continente" ${ }^{31}$

Para isso era preciso, segundo esse pensamento, incrementar a participação do Estado na economia por meio do planejamento global, buscando facilitar o advento de uma industrialização nacional. E para este fim, não se limitando à produção teórica e acadêmica, mas adentrando as esferas da política econômica e do planejamento governamental num esforço de colaboração na execução dos planos de desenvolvimento.

Dessa visão de ação estatal direta no mercado, no entendimento de JK, Brasília seria um marco simbólico, demarcaria uma nova periodização da história nacional. Era a metasíntese do pensamento desenvolvimentista de seu governo que pretendia representar o divisor entre o Brasil arcaico e subdesenvolvido e o Brasil moderno e desenvolvido.

Como observado por Moreira:

"As promessas subjacentes à construção da cidade afirmavam de modo categórico que depois de Brasília e, portanto, depois do governo de JK, o Brasil e seu povo não seriam mais os mesmos. Essa foi a maior promessa inscrita em Brasilia e na ideologia desenvolvimentista de Kubitschek. Juscelino procurou criar com Brasília e a ideologia nacional-desenvolvimentista um lugar de relevo para ele e seu governo" ${ }^{32}$

A idéia de nação brasileira e de desenvolvimento geral e integrado do país tinha sua forma concreta na construção de Brasília, pela ótica de Kubitschek. Dessa forma ela havia se tornado premissa e símbolo de tal ideário, compartilhado por diversos setores, atores e expoentes de cada grupo intelectual da época.

É inegável o efeito desse pensamento, que permeou todo o período JK e mesmo após ele, ao observar declarações, por exemplo, de Lucio Costa que via em Brasília "não um gesto gratuito de vaidade pessoal ou política à maneira do Renascimento, mas o coroamento de

\footnotetext{
${ }^{31}$ MANTEGA, Guido. A Economia Política Brasileira. São Paulo: Editora Vozes, 1984 p. 23

${ }^{32}$ MOREIRA, 1998 p. 37
} 
um grande esforço coletivo tendo em vista o desenvolvimento nacional"33

O mesmo discurso pode ser verificado em Roland Corbisier

“(...) a construção de Brasília não representou o capricho de um Governo nem tampouco o gesto, a decisão arbitrária de um presidente, mas corresponde, ao contrário, a antiga aspiração histórica do povo brasileiro. ${ }^{34}$

A expressão do desenvolvimento preconizado no discurso de Kubitschek, era a forma do discurso do nacional-desenvolvimentismo, no qual as promessas de mudança nas estruturas social, econômica e política do país se fariam pela Marcha para o Oeste ${ }^{35}$, pela marcha para o interior do País.

Essas promessas contidas no discurso juscelinista ressaltavam três pontos-chaves: a melhoria das condições de vida dos trabalhadores e pessoas simples do campo, sem que para isso houvesse sido pensada qualquer política específica ${ }^{36}$; a superação das desigualdades de desenvolvimento regional verificadas; a construção da nova capital e as obras empreendidas como elementos de transformação radical do País.

Todo o discurso baseava-se na interiorização, que tinha significado amplo o bastante para conter uma visão interpretativa e explicativa desenvolvimentista. Tomado para o discurso nacional-desenvolvimentista de JK, o vocábulo "interior" referia-se às vastas regiões do País não-litorâneo, a toda população rural desde os dominados aos dominantes, e à própria atividade econômica agropecuária, especialmente aquela praticada pela elite rural e que tinha um claro viés comercial ou de mercado. É assim que "Juscelino apontou Brasília e o Plano de Metas como medidas claras destinadas a atender ao 'interior' em todos os sentidos já mencionados e, sobretudo, como forma de socorrer as camadas mais humildes daquelas regiões. ${ }^{37}$

${ }^{33}$ COSTA, Lúcio. Registro de uma vivência.

${ }^{34}$ CORBISIER, Roland. Brasília e o desenvolvimento nacional. Rio de janeiro: Instituto Superior de Estudos Brasileiros ISEB, 1960, p. 17.

${ }^{35}$ Política da era Vargas que tinha por premissa investimentos no interior do país, por meio da colonização das áreas agrícolas pouco ocupadas. Essa política tinha por objetivo estratégico a ocupação do território nacional.

${ }^{36}$ Como já citado, há uma permanência quanto às estruturas e formas das políticas quanto à ação governamental no campo.

${ }^{37}$ MOREIRA, Vânia. 1998 p. 32 
O Interior padecia de um isolamento econômico e político que resultava em seu atraso. Imputava ao Estado desenvolvimentista uma solução de integração que, na premissa do Plano de Metas, era representada pela abertura de estradas rumo ao Oeste e a todas as regiões, a partir do centro geográfico, conformando o que foi identificado como o Cruzeiro Rodoviário.

As estradas simbolicamente representavam o caráter civilizador, garantindo uma apropriação mais igualitária do progresso econômico que já se anunciava nos grandes centros urbanos do litoral e sudeste. As estradas distribuíam e redistribuíam melhor a riqueza advinda da sociedade urbano-industrial aos olhos desse pensamento.

A nova capital era o centro geográfico dessa nova estratégia da política econômica, era de onde partiam todas essas estradas marcadamente desenvolvimentistas, numa forma irradiadora de desenvolvimento.

Um viés liberal pode ser notado nessa forma discursiva ao admitir que aproximando, por meio de uma estrutura rodoviária, os centros urbano-industriais do interior agrícola, os benefícios gerados pela economia desses pólos urbanos litorâneos e do sudeste, espraiariam as melhores condições de vida. Essa fala tem garantia nos pensamentos de Adam Smith que estabelece uma justificativa econômica para ação do homem que, em busca de seu interesse particular, cria uma sociedade onde o bem-estar coletivo é uma conseqüência.

Desse discurso nota-se um ponto importante encontrado também em pensadores como Jeremy Bentham e James Mill, que nas palavras de Martin Carnoy entendiam que era dever do Estado "alimentar o sistema de mercado livre e proteger os cidadãos da corrupção e da avidez do próprio governo" 38 .

É, portanto, a partir dessa visão que a expressão do desenvolvimento pode ser representada: na nacionalização do mercado de uma economia brasileira capitalista, representada principalmente pela economia do Sudeste, em conjunto com a nova forma de governo mais racional presente no modelo de Estado moderno que estava sendo implantado desde Getúlio Vargas. Brasília era a cidade dentro do contexto moderno que expressaria isso tudo e sediaria esse novo Estado.

Alguns pesquisadores acreditam que Brasília teve influência no sentido de maior pulverização dos investimentos estatais que até então se realizavam, possibilitando um

\footnotetext{
${ }^{38}$ CARNOY, 2006 pg 44
} 
direcionamento ao interior do país de uma série de políticas, o que poderia ser identificado hoje, se observado apenas o PIB. Segundo o IBGE em 2005 a capital federal representou o terceiro maior PIB municipal com nada menos que 80,5 bilhões $^{39}$ de reais, atrás somente de São Paulo com 263,2 bilhões de reais e Rio de Janeiro com 119 bilhões reais.

É impressionante que o Distrito Federal ${ }^{40}$ contribua com $42,34 \%$ do PIB da Região Centro Oeste figurando como a unidade federativa com maior PIB da região. Em apenas 48 anos de existência como unidade federativa, Brasília é a cidade de maior renda per capita brasileira com $R \$ 34.510,00$, enquanto a média nacional é de $R \$ 11.658,00$ a preços correntes de 2005.

Esses números demonstram a robustez e força da sede física do Estado, e não há como negar o que representa cerca de $3,75 \%$ do PIB nacional, como elemento que altera o quadro regional do centro-oeste. Reafirma que a presença do organismo estatal estabeleceu um pólo consumidor de peso no centro do país, tendo por isso a capital marcado um patamar diferenciado na economia brasileira.

Entender o pensamento que marcou o nacional desenvolvimentismo é entender o Estado como agente planejador da economia, o que foi claramente tomado como pré-condição do Plano de Metas. Essa pré-condição já figurava como condição sine qua non, dos estudos antecessores da Comissão Mista Brasil - Estados Unidos e do Grupo Misto do BNDE CEPAL.

De acordo com Mantega, a Comissão Mista Brasil - Estados Unidos indicava quatro pontos prioritários para o investimento do Estado.

“A - Eliminação dos pontos de estrangulamento que impedem ou dificultam a distribuição da produção existente, ou resultam na subutilização dos recursos produtivos

B - Remoção dos obstáculos à maior expansão da produção agrícola, mineral e florestal, assim como a ampliação de fábricas existentes ou a instalação de novas.

C - Integração do mercado interno em virtude de um sistema mais eficiente de conexões inter-regionais que favorecerão a especialização e produção em larga escala

D - Descentralização da indústria propiciando distribuição mais equilibrada do poder

\footnotetext{
${ }^{39}$ Dados do IBGE para 2005 demonstram que só o setor de serviço é responsável por nada menos que $\mathrm{R} \$ 65,7$ bilhões, ou seja, $81,6 \%$ do PIB.

${ }^{40}$ Importante frisar que o Distrito Federal é considerado unidade federativa (estado) e município concomitantemente, e assim a contabilidade é mesma para o IBGE.
} 
econômico aliviando o congestionamento dos presentes centros industriais. ${ }^{, A 1}$

Vale aqui algumas considerações antes de destacar o trabalho das comissões, na interpretação desse autor, a visão de desenvolvimentismo que mais predominou no Instituto Superior de Estudos Brasileiros - ISEB, no período do governo de Kubitschek, foi a de Hélio Jaguaribe, podendo ser considerada a mais conservadora. Portanto, é possível arriscar-se em afirmar que, como o ISEB representou durante esse mesmo período o órgão da inteligência do governo, e as idéias que ganharam maior destaque desse instituto possuíam um invés mais conservador ${ }^{42}$, a linha adotada pelo governo tendia a ser mais liberal e muito menos radical.

Essa influência estava inscrita no que pode ser considerada por Mantega, a ideologia que "fornecia um projeto político de desenvolvimento que, mal ou bem, argamassava a sociedade civil brasileira e fornecia ao Estado sua base de legitimação"43

Assim, reafirma-se por essa interpretação que a matriz de desenvolvimento de Juscelino Kubitschek era conservadora e liberal, ainda que independentemente disso, e como destacado por Mantega, muitos eram os pontos de concordância entre as correntes internas de pesquisadores do ISEB.

Esses pontos de concordância davam conta que mesmo existindo contradições entre os caminhos teóricos adotados, estes se tornavam secundários comparados ao que consideravam como o ponto chave da questão do desenvolvimento brasileiro: as relações com os "latifúndios feudais" e seus "aliados imperialistas"44 que eram responsáveis pela exploração e o baixo nível de vida da sociedade brasileira.

Marca-se assim que a visão deste desenvolvimentismo é nacionalista, antes de tudo, e industrial, buscando a conversão do trabalhador rural em trabalhador urbano. Para Mantega, essa visão tem forte influência do pensamento da CEPAL, e se insere no que descreve

\footnotetext{
${ }^{41}$ Relatório da Comissão Mista Brasil - Estados Unidos. Observador econômico e Financeiro n. 240/41, fevereiro-março de 1956. p 64.

${ }^{42}$ Vale ressaltar que dentro dos pesquisadores do ISEB existiam diversas correntes, até memo de forte cunho marxista, representadas por exemplo por Ignácio Rangel, Nelson Werneck Sodré e outros

${ }^{43}$ MANTEGA, 1984 p. 63

${ }^{44}$ Expressões do autor
} 
como o "modelo de substituições por importações"

Destacada a referência sobre a influência da CEPAL no pensamento das correntes do ISEB e sua importância no pensamento da economia política do período, retorna-se à questão dos planos governamentais.

No caso da Comissão Mista Brasil - Estados Unidos, como já apontado, eram buscadas formas de intervenção governamental para unificação dos mercados regionais num grande mercado nacional. A matriz que se desejava, colocava a questão do sistema de transporte como um ponto chave, visando à expansão industrial, com a ampliação dos parques já existentes e criação de novos, numa estratégia de descentralização do setor das regiões já industrializadas.

Outro aspecto importante diz respeito à capacidade de investimento tendo em vista a dificuldade de canalizar recursos por parte de agentes internos, pois, segundo a Comissão Mista, o Brasil padecia de uma baixa margem de poupança interna e, por isso, os projetos elaborados contavam com a atração de capital estrangeiro, de poupanças externas.

A título de registro, para induzir tais investimentos, era aconselhada a modificação da política cambial, o que de fato ocorre em 1953 com a retirada do mecanismo de taxa cambial fixa. Mas, apesar de boa parte das considerações da Comissão Mista ser adotada pelo governo, parte dos 41 projetos elaborados não foi adiante, já que um crédito de 500 milhões de dólares do governo dos Estados Unidos não ocorreu (mudança de administração do democrata Truman, para o republicano Eisenhower).

Assim, seguindo parte considerável das discussões até então formuladas no âmbito da Comissão Mista, em 1953 surge o Grupo Misto BNDE - CEPAL que dá prosseguimento a essa nova forma de ação do Estado na economia.

O Banco Nacional de Desenvolvimento Econômico - BNDE foi criado em 1952, se tornando o principal agente financiador de investimentos no país, de maneira a facilitar as ações para a expansão industrial, que a partir da segunda metade da década de 50 aplica seus esforços em infra-estrutura, buscando atender ao que foi preconizado pela Comissão Mista, no sentido de diminuir ou eliminar os estrangulamentos nos setores de energia, transporte e insumos básicos.

O Grupo, chefiado por Celso Furtado, tinha o propósito nítido de complementar os trabalhos

\footnotetext{
45 Segundo Mantega, modelo este elaborado por Celso Furtado, Ignácio Rangel e Maria da Conceição Tavares entre outros, observando os extensos estudos da CEPAL.
} 
da Comissão Mista e elaborar um programa de desenvolvimento para o período de 1955 a 1962. Um dos diferenciais importantes desse grupo é o reconhecimento de condicionantes internos ao processo de acumulação, segundo Mantega, mesmo que o peso das análises da Comissão Mista quanto aos estímulos externos ainda prevalecessem.

Para Chico de Oliveira, o Plano de Metas é o resultado direto dos trabalhos desse grupo. Em suas palavras "para muitos analistas da história do período, parece como se o Plano de Metas fosse algo como 'um raio num dia de céu azul', quando na verdade é no referido documento do Grupo Misto que se deve sua 'rationale'."46

Faz parte de uma mitificação do Plano de Metas sua pretensa originalidade, mas como se vê ele é conseqüência de um planejamento que vinha sendo formulado. Em resumo, o Plano de Metas tinha por objetivo remanejar os recursos do país de modo a direcioná-los à expansão da acumulação industrial, dando continuidade ao que já havia sendo executado, por meio da atuação direta do governo, em duas frentes prioritárias:

Coordenação e integração dos vários setores da economia, detectando as deficiências de infra-estrutura e as lacunas deixadas pela iniciativa privada, e procurando solucionar esses problemas pela ampliação ou criação de empresas estatais;

Incentivo direto à produção privada por meio da criação de linhas especiais de crédito, principalmente junto ao BNDE, com longos prazos de restituição e juros negativos, pela concessão de avais estatais a empréstimos contraídos no exterior, pela facilitação de importação de máquinas, equipamentos e insumos básicos com concessão de taxas cambiais favorecidas, pela concessão de isenções fiscais e tributárias e pela reserva de mercado à industrias em implantação via tarifas protecionistas;

Em uma arriscada transposição de interpretação, Brasília seria a materialização do centro urbano desse pensamento desenvolvimentista, notada sua forma de implantação, já que faz uso de uma empresa estatal especialmente criada para este fim, investido recursos num território que nenhuma outra empresa privada industrial tinha condições ou pretensões de investir, aproveitando-se de políticas de crédito facilitados por esta mesma empresa através de captação de recursos internacionais com avais do Estado e recursos próprios.

E ainda, redirecionando uma quantidade considerável de investimentos estatais, a exemplo dos recursos dos Institutos de Aposentadoria e Previdência, Fundação Casa Popular,

\footnotetext{
${ }^{46}$ OLIVEIRA, Francisco M. C.. A Economia da Dependência Imperfeita. Rio de Janeiro: Editora Graal, 1977 , p. 84
} 
recursos próprios de Ministérios, sendo no início de sua execução isenta de uma série de cargas fiscais e tributárias.

Assim, implantar Brasília era implantar o símbolo urbano do desenvolvimentismo jucelinista, e como o próprio presidente gostava de se referir: "meta-sintese".

\subsection{Questão da mudança}

A transferência da capital para o interior sempre teve sua argumentação pautada em inúmeros motivos ao longo da história, como argumenta Faret:

“(...) primeiro, uma tentativa de apagar todos os vestígios e símbolos da dominação portuguesa, como seria, no caso, a cidade do Rio de Janeiro; segundo, uma medida destinada a transformar o Brasil num país unificado, ao invés de um grande número de enclaves; terceiro, por razões de defesa nacional, uma vez que a capital seria altamente vulnerável a ataques estrangeiros; quarto, um meio de promover novos padrões de eficiência no serviço público; quinto, um instrumento ideológico capaz de criar, junto às massas, um espírito de identidade nacional; sexto, um centro de crescimento capaz de promover o desenvolvimento regional do Centro-Oeste, através da criação de um significativo mercado consumidor e da introdução de inovações tecnológicas, econômicas e sociais; e sétimo, como uma porta de entrada à ocupação econômica das fronteiras oeste e norte do País ${ }^{\text {,47 }}$

Em um histórico sobre a mudança da capital para o interior, ou seja, a interiorização do centro político, pode-se remontar ao período colonial de Marquês de Pombal em 1761, passando pelas reivindicações de movimentos de independência como a Inconfidência Mineira em 1789, a discursos e documentos de conselheiros da Coroa Portuguesa em 1809 e 1810 (Chanceler português Veloso de Oliveira e a William Putt) e a publicações de 1813 em jornais da metrópole portuguesa (Hipólito José da Costa Furtado - Correio Braziliense).

Essa aspiração ainda do Brasil-Colônia está presente no Brasil-Império, na ação de figuras como José Bonifácio que exerce sua influência na Assembléia Constituinte entre 1821 a 1823, para que o tema esteja presente nas discussões e no texto final da Constituição; também na figura do Visconde de Porto Seguro, Francisco Adolfo de Varnhagen, que defende a interiorização entre 1850 e 1877, escrevendo documentos e relatórios

47 FARET, Ricardo L. O Estado, a questão territorial e as bases da implantação de Brasília in: PAVIANI, Aldo (org). Brasília, ideologia e realidade: Espaço urbano em questão. São Paulo: Projeto, 1981 p. 20 
patrocinados pela própria Coroa.

No Brasil República a temática sempre encontra um lugar de discussão no cenário nacional e, em 1891, na primeira constituição republicana, em seu $3^{\circ}$ artigo, aparece a questão da mudança da capital para o interior, passando a partir dessa data a estar presente em todas as constituições que se seguem e em documentos governamentais.

É então em 1892 que a primeira ação ocorre, quando o governo institui uma comissão para o estudo de localização da nova capital da república. A Comissão é chefiada pelo Dr. Luís Cruls que faz o primeiro grande relatório de estudos de localização resultando na demarcação do primeiro terreno no planalto central de Goiás. É então em 1922, na cidade de Planaltina, que se "planta" a pedra fundamental da Nova Capital da república.

Mas, são necessários outros 33 anos até que um candidato à presidência da república assuma essa transferência como parte integrante de um plano de governo, sendo ela considerada o objeto síntese de sua proposta de governo, e como ação em respeito aos preceitos constitucionais.

Uma rápida explanação dos bastidores do processo de mudança, se apresenta de utilidade. Em 5 de novembro de 1946, num período de redemocratização pós Estado Novo, no governo de Eurico Gaspar Dutra, é instituída a Comissão de Estudos para a Localização da Nova Capital, que, após dois anos de trabalhos, apresenta como resultado final o que pode ser considerado como o relatório mais completo até então formulado sobre a localização e viabilidade de transferência da capital da república para o interior. Este relatório é conhecido pelo nome do presidente da comissão, o general Djalma Polli Coelho.

O Relatório Polli Coelho é entregue em 4 de agosto de 1948, com recomendações específicas de como deveriam proceder às ações de transferência, capacidade do sítio escolhido tendo em vista a população, recursos naturais e as questões iniciais de abastecimento da nova capital.

Nos relatórios de estudos e planejamento para a nova Capital, encontram-se preciosas observações sobre o processo de concepção, não só no que diz respeito a aspectos geográficos, mas ao próprio desenho social que se tem como panorama de estudo.

"Este relatório se compõe de três partes. A primeira é formada pela resolução final da Comissão acompanhada de Justificação, escrita por esta presidência, dessa resolução final. Por esta primeira parte se verifica que a Comissão pensa ter alcançado um resultado consistente, que está de acordo primeiro com o espírito e depois com a letra da Constituição. Mantivemos a tradição de solução do problema, aproveitando integralmente a área proposta em 1892 pela Comissão Cruls. Mas não tivemos a idéia 
pura e simples de respeitar uma tradição. Ampliamos consideravelmente essa área para o Norte, sobre a bacia amazônica, aproveitando uma série de trechos fluviais para Ihe dar limites já demarcados pela natureza, o vem a simplificar a passagem das terras à jurisdição do governo federal. ${ }^{\sharp 48}$

O Relatório Polli Coelho diagnosticava que o território escolhido com $70.000 \mathrm{~km}^{2}$, que portanto transcendia ao demarcado pela Comissão Cruls $\left(14.400 \mathrm{~km}^{2}\right)$, seria capaz de prover $80 \%$ das necessidades próprias da capital federal e seus futuros habitantes, reconhecendo que, independente de qual fosse a área ser transferida à União para a criação da nova unidade, haveria sacrifícios à nação de toda a ordem.

No estudo já havia manifestação quanto ao planejamento da mudança e ao financiamento do empreendimento que, ainda, previa investimentos estatais em infra-estruturas de grande porte, como represas para fornecimento de água e energia elétrica, redes elétricas e rodoviárias, buscando especificar períodos de transferência dos órgãos estatais e de seus funcionários.

É a partir desses parâmetros que se pretendia criar pré-condições para o estabelecimento do máximo de auto-suficiência, e assim se entendia que a área eleita, doze vezes maior que a atual $\left(5.802 \mathrm{~km}^{2}\right)$, conseguiria suportar o atendimento a uma população urbana de 250.000 habitantes, num entendimento que a capital seria exclusiva à função administrativa.

Este pensamento norteador da comissão incitava uma visão na qual os opositores à transferência identificavam com certa facilidade um símbolo aristocrata, com propósitos meramente políticos. Afirmavam que se tratava de uma nova Versalhes incrustada no cerrado.

A essa altura, Juscelino Kubistchek já figurava como um dos políticos defensores da mudança da capital para o interior, e em 1946, já deputado federal, discursa em defesa da mudança, precisamente para o triângulo mineiro, indo ao encontro de vários outros que ansiavam pela mesma localização. Há uma mudança desse entendimento posteriormente, principalmente devida à movimentação da bancada de políticos de Goiás e à ação do governo daquele estado que tomaram a idéia de transferência como bandeira unificada.

Não é então de se surpreender que a Comissão de Estudos para Localização da Nova Capital, criada em 1946, é reeditada nos governos seguintes, de Vargas e Café Filho, mas é em 1955, sob a presidência do Marechal reformado José Pessoa Cavalcanti de

\footnotetext{
${ }^{48}$ BRASIL/Presidência/Serviço de Documentação. Antecedentes históricos: 1549-1960. Rio de janeiro 1960; pg. 434.
} 
Albuquerque, que se define a área que se tornou definitiva. Menor que o polígono da missão Cruls, o atual quadrilátero do Distrito Federal é resultado de estudos de fotoanálise e interpretação da empresa contratada Donald Belcher \& Associates.

O relatório final, conhecido como Relatório Belcher, demarca sítios específicos à implantação do futuro núcleo urbano da nova capital, apresentando um excelente suporte técnico, sendo escolhidos os sítios: Castanho para a implantação do Plano Piloto, e o Verde, regiões situadas entre o Rio Descoberto, a leste, e o Rio Preto, a oeste.

MAPA I Áreas marcadas pela Missão Cruls, pelo Relatório Belcher e a área definitiva do Distrito Federal com os respectivos sítios estudados pela empresa Donald Belcher \& Associates.

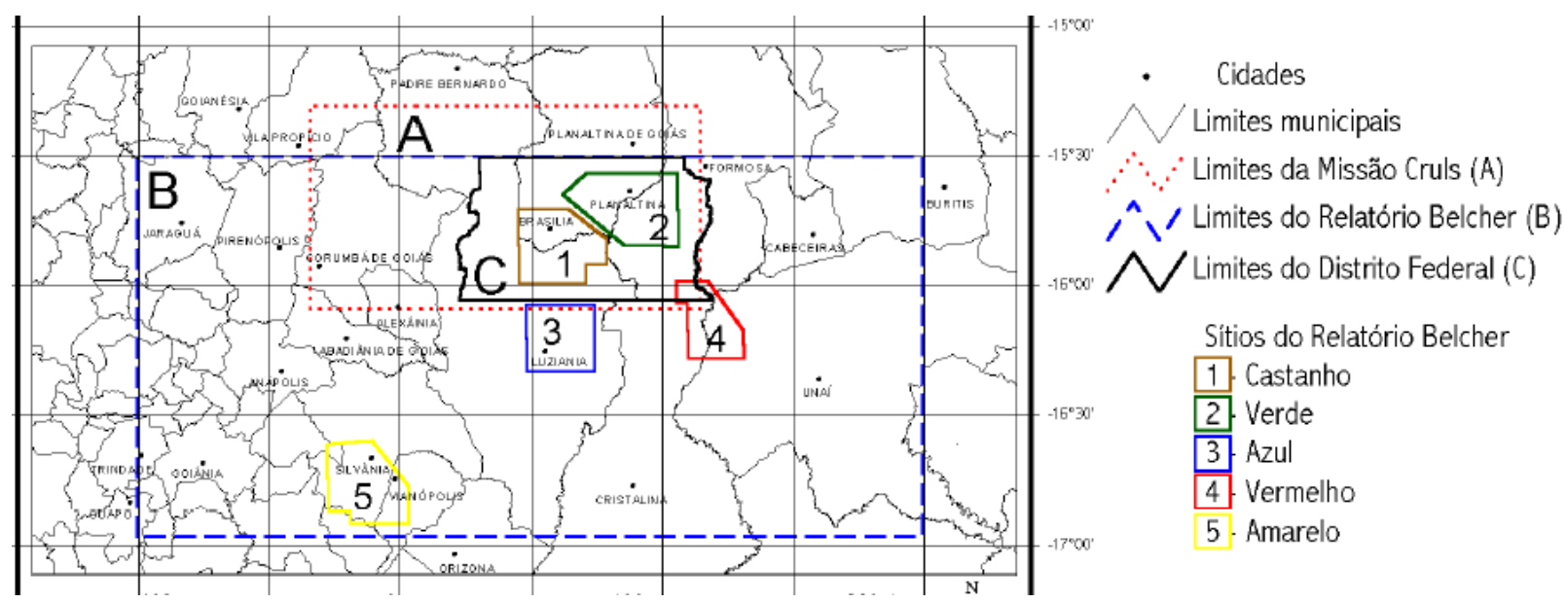

Fonte: Governo do Distrito Federal - Secretaria de Estado e Recursos Hídricos.

Apesar de freqüentar os debates políticos, a questão da mudança nunca foi tema altamente relevante, provavelmente o único segmento que sempre teve a questão como fundamento era aquele ligado ao pensamento geopolítico, que foi se estruturando, tornando-se pontochave para os setores militares. O que explicaria a tradicional presença de militares na presidência das Comissões de Localização. E o que permite perceber do porque Brasília não foi um projeto deixado de lado no regime militar, ao contrário, nota-se uma preocupação na conclusão da transferência da capital para o planalto central, no período mais crítico do regime militar pós 68 .

A Nova Capital, no pensamento geopolítico ao qual os setores militares se filiavam, era fundamento da política nacional, e interpretações que buscam entender como um planejamento urbano modernista de princípio socializante se prestou a um regime não democrático, encontrando aceitação dentro desse regime, perdem de vista uma motivação basilar de uma estratégia territorial nacional do pensamento geopolítico, perdem de vista a forma de ordenamento urbano que tal planejamento representa no ambiente urbano, o qual 
tem também parentesco ao princípio do comportamento militar positivista, da "ordem e progresso". Não pode-se esquecer, por exemplo, que a aplicação da doutrina de Cloude Saint-Simon, considerado como um socialista utópico, às políticas fiscais urbanas possibilitou a maior reconstrução de uma capital européia no século XIX, a Paris de Haussmann. ${ }^{49}$

Desse pensamento geopolítico ligado quase que estritamente a uma questão de maximizar a segurança do Estado, para uma visão onde o pensamento econômico e social fossem incorporados à idéia de interiorização, efetivamente só ocorre de maneira mais abrangente no governo de Juscelino Kubitschek, que aproxima dois pensamentos de nacionalidades distintos. Aproxima o pensamento geopolítico com o da economia política.

Como candidato à presidência, põe o tema na agenda das discussões políticas e sociais, ampliando o debate sobre a questão da mudança. Mesmo que houvesse uma contínua burocracia ligada ao tema, aparentemente ela se compunha para atender a um grupo de interesse, dos quais os políticos do interior e os militares do país eram partes integrantes.

Debate criado, entra em cena o Instituto Superior de Estudos Brasileiros - ISEB, que se torna um dos principais atores de defesa da interiorização, tendo Roland Corbusier ${ }^{50}$ e Hélio Jaguaribe como debatedores do tema.

$\mathrm{Na}$ arena de maior e mais acalorada discussão entre mudancistas e antimudancistas, o Congresso Nacional, é que o tema ganha palco e repercussão nos jornais, sindicatos, entidades estudantis e outras organizações. Segundo Moreira, "o Parlamento comportou-se como um órgão sensível aos problemas e interesses suscitados pela questão mudancista", se apresentando como um organismo de Estado. Nos termos gramscianos um organismo da sociedade civil. O debate e ação do parlamento tornaram públicos diversos interesses, sendo ele próprio influenciado e influenciando as diversas discussões suscitadas.

Mas, já em 1955, aprova-se no congresso para o orçamento da União de 1956, uma verba de $\mathrm{Cr} \$ 120.000 .000,00$ para as despesas decorrentes com a desapropriação da área do Distrito Federal, com indenização ao Estado de Goiás.

A indenização ao estado de Goiás era devida às providências quanto a processos de desapropriações iniciados por aquele estado a partir de outubro de 1955, a pedido do

\footnotetext{
49 RYKWERT, Joseph. A sedução do Lugar: a história e o futuro da cidade. São Paulo: Martins Fontes, 2004, p.79.

${ }^{50}$ CORBISIER, 1960.
} 
presidente da comissão de localização da nova capital, Marechal José Pessoa, endossado por Juscelino.

Havia um grupo político determinado a viabilizar a mudança da capital para o centro do país, e a disputa do território entre Goiás ou Triangulo Mineiro era notória ${ }^{51}$, mas o grupo goiano vence defendendo o relatório final da Comissão Pessoa.

Outro momento crucial e marcante no processo da mudança se relaciona com a criação da Companhia Urbanizadora da Nova Capital - NOVACAP, pois marca a forma da prática política adotada durante o governo Juscelino Kubitschek para a implementação das ações componentes do Plano de Metas.

É em 18 de abril de 1956 que Kubitschek envia mensagem para a apreciação do Congresso, o projeto de lei sob o n. 946 que autorizava o executivo a constituir a NOVACAP, a adaptar o Plano Viário Nacional para garantir a comunicação de todas as regiões com a futura capital $^{52}$, a dar garantia do Tesouro às operações de crédito negociadas pela própria companhia para o financiamento do empreendimento, além de atribuir a execução de serviços não especificados em suas atribuições, fosse por contrato ou concessão.

O Estado investia a essa nova estrutura poderes de contratação direta, execução e garantias orçamentárias sem precedentes, boa parte deste projeto de lei foi idealizado e estruturado por San Thiago Dantas, antigo membro da Comissão Mista Brasil - Estados Unidos. A base política desse projeto era a concentração do poder decisório na presidência e a "tecnocratização" da gestão administrativa. Segundo Moreira, é principalmente nesse aspecto que a "NOVACAP chega mesmo a superar o que se convencionou chamar de ‘administração paralela"

O projeto atribuía à companhia uma autonomia extremamente ampla, de forma que, na prática, sua criação desvinculava a operação de mudança da administração direta e indireta, isolando as pressões parlamentares à burocracia do Estado na qual tinham influência importante. Essa "blindagem" para a execução da meta-síntese foi composta de mais

\footnotetext{
${ }^{51}$ Ver FARIAS, Darcy Dornelas de. Terras no Distrito Federal - experiências com desapropriação em Goiás (1955-1958). Dissertação de Mestrado Departamento de História da UnB. 2002

52 O Cruzeiro Rodoviário, um dos marcos do Plano de Metas. Ressalta-se que, dentre as ações planejadas foi a que superou as estimativas iniciais, construindo quase que o dobro da rede prevista.

${ }^{53}$ MOREIRA, 2002, p. 38
} 
elementos do que apenas a forma e a estrutura da NOVACAP e, de certo, contou com a habilidade política do presidente, como ressalta Moreira e outros autores ${ }^{54}$.

O que impressiona na estrutura da NOVACAP é que se baseava nas sociedades anônimas de direito privado, iniciando suas atividades com um capital de 200 milhões de cruzeiros, podendo ser ampliado mediante aprovação legal de novos recursos. E ainda, possuía um Conselho Administrativo cujas deliberações a Diretoria Executiva deveria executar, mas caso não concordasse, poderia recorrer diretamente ao presidente da República. Todos os cargos eram de nomeação direta do presidente, o que demonstra a forte centralização das decisões na Presidência da República.

A manifestação oficial ditava que a companhia se organizaria "segundo o tipo de empresa industrial do Estado", e que o projeto de Brasília era autofinanciável, por meio da comercialização dos lotes resultantes do parcelamento da terra urbana, estimando-se que os 80.000 lotes previstos ${ }^{55}$, nos modelos adotados de estudos, resultariam numa receita de 24 bilhões de cruzeiros.

Obviamente, a apresentação de tais números visava dois aspectos: primeiro apresentar uma solução de empreendimento na qual os gastos com a operação de mudança contariam com uma entrada de recursos diferenciada da receita do Estado; segundo marcar a importância da criação da NOVACAP no modelo apresentado, como única maneira de viabilizar tais visões de planejamento, já que a maior justificativa para a implantação da companhia estava no discurso vinculado com a ineficiência dos aparelhos administrativos públicos a época.

O que colaborava para essa concepção era exatamente a idéia de que o Estado precisava assumir um novo papel e que deveria atuar diretamente no desenvolvimento econômico e social do país. Como foi anteriormente citado, a ideologia do desenvolvimentismo já percorria amplos segmentos dos grupos de interesse que ocupavam o poder, até mesmo círculos e grupos que formavam a dita opinião pública comungavam dessa visão.

Não existia reforma administrativa aventada, o que facilitava o processo, já que os grupos

\footnotetext{
${ }^{54}$ Autores como Maria Benevides, já citada em nota, enfatizam Juscelino Kubitschek como um dos políticos mais carismáticos e eficientes, quando observada sua prática política ao compor seu corpo admnistrativo.

${ }^{55}$ Ainda não se refere ao projeto do Plano Piloto de Lúcio Costa e sim aos estudos da Comissão de Localização e Mudança.
} 
políticos que possuíam influência em determinados pontos decisórios ${ }^{56}$ do Estado não se sentiam afrontados diretamente.

A NOVACAP se apresenta como conciliadora desse processo, pois não interferia no lócus de poder de determinados grupos e garantia uma autonomia plena ao processo de implementação do Plano de Metas.

Mesmo com uma acomodação de interesses, tendo em vista o exposto, houve manifestações fortes em contrário à ampla autonomia da companhia e várias foram as maneiras de discutí-la, sendo que, a que resultou na solução do impasse para a aprovação, consistia em que o presidente da república deveria nomear para parte da diretoria representantes do maior partido de oposição, a UDN. A oposição requeria a presidência da companhia e foi apresentada a Juscelino uma lista tríplice onde constavam os nomes do expresidente Café Filho, de Jales Machado e de Íris Meinberg.

Dada a maneira e comportamento com que o ex-presidente Café Filho procedeu quanto aos distúrbios anteriores à posse ${ }^{57}$, e ser um nome pouco simpático ao Ministro da Guerra Teixeira Lott, foi vetado de pronto. Quanto ao deputado federal Jales Machado, sua relação conflituosa com o governador do estado de Goiás, não se apresentava como uma solução adequada já que abalava as relações estabelecidas entre Juscelino e o governador goiano José Ludovico de Almeida o qual procedia às primeiras ações de desapropriações.

Assim, ignorando o pleito da oposição, Juscelino Kubitschek nomeia para o cargo de

${ }^{56}$ Codadto e Perissinoto assim descrevem os: "[...] o Estado (ou, mais propriamente, o sistema institucional dos aparelhos do Estado) é um conjunto complexo com níveis dominantes - o que Marx chama também de postos decisórios - , de onde se controlam efetivamente as rédeas da administração, e níveis subordinados (sem qualquer poder executivo, como se viu); a tarefa da análise política marxista é, justamente, determinar quais são os aparelhos em que se concentram o verdadeiro poder de Estado. O que se poderia chamar de centro(s) de poder real é, nesse contexto, o lugar imprescindível para o exercício da hegemonia de classe. Cumpre enfatizar, portanto, que o poder real é a emanação direta de uma série de recursos institucionais - a administração, o orçamento, o poder executivo enfim -, concentrados num ramo específico do aparelho estatal, e que, através dele, confere à classe social que o controla uma posição superior na luta política." (grifo meu), ver CODATO, Adriano Nervo e PERISSINOTTO, Renato Monseff. O Estado como instituição. Uma leitura das Obras Históricas de Marx. In: Crítica Marxista n. ${ }^{\circ}$ 13. São Paulo: Boitempo editorial. out/2001;

${ }^{57}$ Refere-se ao Levante das Garças, sendo uma das muitas "revoltas" oriunda de dentro das casernas brasileiras, contra alguma situação política. 
presidente o então deputado federal Israel Pinheiro, político experiente, pessoa de sua confiança com experiências anteriores que the respaldavam, tendo sido o primeiro presidente da Companhia Vale do Rio Doce, o deputado federal e fazendeiro Íris Meinberg, o único representante da UDN para a diretoria de finanças, Ernesto Silva então presidente da Comissão de Estudos e Localização da Nova Capital ${ }^{58}$ e Bernardo Sayão ${ }^{59}$ então vicegovernador de Goiás pelo PSD.

Para se ter uma percepção do processo, em 19 de setembro de 1956, o Congresso aprova a criação da companhia, por meio da lei 2.874. O trâmite rápido, de apenas 5 meses, demonstra que apesar das divergências e discussões suscitadas existia uma coalizão sobre a urgência do tema. Para alguns membros do congresso como, o deputado federal Carlos Lacerda, seria a forma de sepultar o governo de Juscelino Kubitschek e seus sucessores, já que acreditava na impossibilidade de em tão curto espaço de tempo executar tal obra. $O$ próprio Juscelino inicialmente se manifestara oficialmente que seriam necessários 15 anos para completar a transferência total da capital. E dentro do espírito de "sepultamento", a oposição no parlamento apóia também a proposta de lei na qual estabelecia o dia 21 de abril de 1960, como data de inauguração da cidade, sendo aprovada em 1957.

Segue-se ao início da desapropriação do território, à formalização da companhia, da instalação do canteiro e das obras de alguns edifícios públicos, o concurso para escolha do projeto urbanístico da nova capital ${ }^{60}$. E em 10 de março de 1957 é escolhido o projeto urbanístico de Lúcio Costa para o Plano Piloto de Brasília, não com menos polêmica já que

${ }^{58}$ Ernesto Silva era assessor direto do Marechal Pessoa que deixa o cargo no final de 1955 , assumindo provisoriamente o cargo, sendo logo em seguida, nomeado por Juscelino Kubitschek como presidente da Comissão de Planejamento da Mudança e Construção da Nova Capital.

${ }^{59}$ Bernardo Sayão eleito, em 1954, com mais votos que o próprio governador do estado de Goiás, era visto e identificado como uma figurava altiva, "homem de ação". Em 1955, ocupou durante 3 meses o cargo de governador, enquanto aguardava eleições suplementares que legitimaram a posse do governador José Ludovico de Almeida. Com sua morte durante as construções da rodovia Transbrasiliana (Belém-Brasília) tornou-se o primeiro herói-símbolo do desenvolvimentismo juscelinista. A quem veja na figura de Bernardo Sayão, também, o homem que ajudou a inspirar os "candangos" durante toda a construção da cidade (ver Adirson Vasconcelos, Ernesto Silva).

${ }^{60}$ Convidado por Juscelino para executar todos os edifícios públicos da nova capital, Niemeyer se recusa a fazer o projeto urbanístico sugerindo a instituição de um concurso internacional para a escolha do projeto. Mas 1956, já estava em construção o Palácio da Alvorada, no local da primeira fazenda a ser desapropriada, fazenda Bananal. 
o jurado do IAB, manifesta-se contrário ao parecer final da comissão julgadora.

\subsection{Brasília e o planejamento moderno}

"A ilusão retrospectiva fica evidente quando Brasília é citada por todos para justificar as esperanças que precederam o golpe. Visa com alguma distância, longe de representar 'uma otimista atividade antecipatória' do sentido coletivista da produção', Brasília reproduziu as contradições da modernização brasileira em escala inaudita. Sem entrarmos no significado do projeto, basta lembrar que a capital foi erguida em quatro anos num dos canteiros mais selvagens da história. Alojados em condições subumanas, trabalhando mais de doze horas por dia, obrigados a fazer viradas e horas extras incessantes, centenas de 'candangos' morreram, quando não caídos dos andaimes, assassinados a mando da construtora. Ao fim, não tiveram direito a um espaço na cidade e fizeram suas casas precárias nos acampamentos satélites. Brasília talvez tenha realmente sido a síntese da arquitetura brasileira, mas longe de mostrar na 'beleza' de seus palácios as esperanças de uma 'alvorada', ela parece encarnar a própria promessa monstruosa da modernização brasileira. ${ }^{161}$

A frase final mais serve a um desfecho do pensamento sobre o estado de confusão e desilusão gerado pela promessa modernista não cumprida a mudança da sociedade por meio do planejamento modernista, da nova arquitetura do que realmente a uma conclusão de um efeito catalisador de uma sociedade desigual, da qual Brasília seria sua representação. Não que seja impossível essa leitura, contudo, admite aos arquitetos da época um romantismo frustrado.

A escala do empreendimento era inegavelmente absurda, estonteante. $\mathrm{Na}$ ação da qual os trabalhadores estavam também envolvidos emocionalmente, residia a idéia da construção da nova nação, muito mais que a construção da nova capital. A esta idéia se dedicavam em três turnos diários, absolutamente exaustivos, todos os dias da semana, durante as vinte e quatro horas do dia, com um número enorme de horas-extras.

Trabalhadores com pouco ou nenhum treinamento ou capacitação, numa corrida desesperada para respeitar os cronogramas selvagens que se impunham, conseguiram em três anos e meio após os inícios da obra que aproximadamente um sétimo do Plano Piloto

${ }^{61}$ ARANTES, Pedro Fiori - Arquitetura nova: Sérgio Ferro, Flávio Império e Rodrigo Lefèvre, de Artigas a mutirões. Ed. 34, São Paulo, 2002 pg.48 
de Lúcio Costa tivesse sido erguido.

"Brasileiros das mais variadas regiões e das mais distintas condições sociais deslocaram-se para o planalto central do Brasil, e mesmo que os vários e diferentes trabalhos objetivados durante a construção fossem conflitantes entre si, nem por isso Brasília teria, hipoteticamente, deixado de ser o símbolo da 'unidade nacional"'62

A representação concreta dessa idéia de nacionalidade e desenvolvimento estava também na escolha do projeto urbanístico a ser implementado, o qual era filiado à modernidade e a racionalidade. Era a representação de uma época no urbanismo e arquitetura mundial.

Há de se considerar que, com freqüência, explica-se a concepção urbanística de Brasília como sendo a transposição do modernismo funcionalista preconizado pelos Congrès Internationaux d'Architecture Moderne - CIAM (Congressos Internacionais de Arquitetura Moderna), no documento Carta de Atenas.

A Carta tornou-se um ícone, um fetiche modernista que visava dar aos centros-urbanos mundiais uma solução para o que identificava como o caos.

Para James Holston em a Cidade Modernista "Brasilia é uma cidade dos CIAM. Na verdade, é o exemplo mais completo já construído das doutrinas arquitetônicas e urbanísticas apresentadas pelos manifestos dos CIAM' ${ }^{63}$ E sua argumentação se filia na influência dos projetos de Corbusier e da ligação formalizada entre ele e seus discípulos Lúcio Costa e Oscar Niemeyer, no projeto do edifício do Ministério da Educação e Saúde de 1936. A denominação de discípulo a Lúcio Costa, especialmente, ignora a formação e o percurso acadêmico deste arquiteto e urbanista, como será abordado mais adiante no item sobre a concepção de Brasília.

É, dessa maneira, importante buscar alguns elementos para discussão, sobre os preceitos da Carta de Atenas e dos próprios Congressos para observar o que cabe da formulação: Brasília é uma cidade do CIAM?

A própria interpretação apresentada por Arantes tem em muito, o que seria um presságio dos Congressos, e como afirma Holston:

"A cidade dos CIAM é concebida como uma cidade da salvação. É apresentada como um plano de libertação frente à 'trágica desnaturalização do trabalho humano' produzida

\footnotetext{
${ }^{62}$ BICCA, Paulo. Brasília, mitos e realidade in: PAVIANI, Aldo (org). Brasília, ideologia e realidade: Espaço urbano em questão. São Paulo: Projeto, 1981 p. 102

${ }^{63}$ HOLSTON, James. A cidade modernista. São Paulo, Companhia das Letras, 1993, p. 37
} 
nas e pelas metrópoles da sociedade industrializada. De acordo com a doutrina dos CIAM, tal cidade constitui uma solução para as crises urbana e social atribuída à dominação irrefreada dos interesses privados no âmbito público da cidade, na acumulação da riqueza e no desenvolvimento da indústria. ${ }^{164}$

Dessa forma vale uma apreciação do tema

\subsubsection{Os CIAM e os preceitos da Carta de Atenas}

"Ao longo de sua reprodução social, incansavelmente o Brasil põe e repõe idéias européias, sempre em sentido impróprio (...) partimos da observação comum, quase uma sensação, de que no Brasil as idéias estavam fora de centro, em relação ao uso europeu. ${ }^{, 65}$

Uma indagação recorrente nas pesquisas sobre a nova capital federal no planalto central é a que procura filiá-la a uma cidade dos CIAM, se é resultado da direta aplicação da Carta de Atenas. Contudo, a contribuição dessas pesquisas, por vezes, não responde a questão principal: Uma cidade projetada sob o preceito da Carta de Atenas, ou mesmo sobre os preceitos do modernismo é ou não a solução para o dito "caos urbano"? E mais, se a fórmula é reprodutível em qualquer momento, em qualquer território e em qualquer nação?

Para construir um ponto de análise será feita a seguir uma leitura dos pontos do CIAM e do documento mais representativo desses congressos para o urbanismo moderno, a Carta de Atenas.

As abordagens iniciais dos primeiros congressos enfatizam a habitação. Uma forte discussão sobre os padrões mínimos de salubridade e da própria característica das residências é o foco do II CIAM em Frankfurt de 1929.

Das experiências em curso para habitações subvencionadas pelo Estado, em especial na Alemanha ${ }^{66}$, concretiza-se um padrão residencial com área consideravelmente reduzida em

\footnotetext{
${ }^{64}$ HOLSTON, 1993, p. 47 (grifo do autor)

${ }^{65}$ SCHWARZ, Roberto. Idéias fora do Lugar. In: Cultura e Política. São Paulo: Paz eTerra, 2005 p.80/81

${ }^{66}$ Em 1926, foi constituído o grupo alemão Der Ring, que queria se caracterizar como a organização profissional da qual faziam parte, além de Ernst May, figuras importantes como Walter Gropius, Bruno Taut, Hugo Häring, Martin Wagner e Peter Behrens. Vários arquitetos desse grupo participaram dos projetos de habitação subvencionada, Ernest May comandou os trabalhos em Frankfurt e foi
} 
relação às tradicionalmente verificadas nas construções. Entretanto, estas novas unidades deveriam contar com maior ventilação, iluminação e insolação, além de uma compartimentação que garantisse certa independência aos membros adultos.

Admitia-se assim, que o partido arquitetônico para unidades habitacionais deveria ser concebido com cômodos destinados a poucas pessoas e com áreas reduzidas. Porém há um fator que deve ser considerado como contrapartida a esse programa arquitetônico que privilegia a individualidade, no interior da residência, da propriedade privada, a tendência solidarizante, segundo Leonardo Benévolo, em História da Arquitetura Moderna. Essa tendência melhor se expressaria nas habitações coletivas, nas quais haveria uma maior interação social externa à unidade habitacional.

O programa moderno para habitações marca essa leitura, que se depara com um problema de fundo, o econômico, já que se destina na essência de sua racionalidade ao atendimento de uma população empobrecida pela conjuntura européia. No programa moderno do CIAM caberia então ao Estado subvencionar habitações com os mínimos padrões de salubridade ${ }^{67}$.

Parte desse raciocínio foi incorporada nas ações do Estado brasileiro das décadas de 30, 40 e 50, contudo, as realidades distintas da Europa entre guerras e pós Segunda Guerra não é a mesma do Brasil nas mesmas épocas, e mesmo posteriormente. Na primeira, há uma sociedade já proletarizada com economia pautada numa industrialização da segunda revolução consolidada, enquanto no Brasil uma sociedade rural sendo forçada a se tornar proletária, em conjunto com um processo de industrialização incipiente que se conjuga com um momento de criação das bases do Estado moderno.

Assim, em meio à estruturação e definição do papel do Estado brasileiro, é assumida como proposta de atuação, como modelo, a mesma política de países como a Alemanha industrial, onde os custos de produção da habitação subvencionada deveriam então ser resultado de uma associação da minimização do que seria desperdício, com o aumento de produtividade.

O processo de consolidação do pensamento do CIAM passa da minimização do custo do terreno e da urbanização e chega à discussão do bairro e, desta à discussão da cidade. E é

provavelmente o mais atuante neste aspecto.

${ }^{67}$ Os padrões de salubridades inicialmente adotados são resultado da sociologia da época, de estudos de higienistas, e até de teorias evolucionistas. Gropius por exemplo se referencia em F. Muller-Lyer. 
no III CIAM que Le Corbusier levanta a questão da cidade e da autoridade encarregada de promover as soluções consideradas mais adequadas.

Do discurso de Le Corbusier vale um destaque:

"Devemos manter-nos ao corrente, pessoalmente, das formas que assume a atual evolução, mas, peço-vos, não nos ocupemos aqui de política e de sociologia. Esses dois fenômenos são demasiada e infinitamente complexos; existe também o aspecto econômico, e nós não estamos qualificados para discutir no Congresso esses árduos problemas. Repito, devemos permanecer arquitetos e urbanistas e nesse, terreno profissional, fazer conhecer a quem de direito as possibilidades e as necessidades de ordem arquitetônica e urbanística. ${ }^{, 68}$

O discurso é resultado da dificuldade que o movimento encontra na materialização de seu ideário, de seu programa. Enfatizando a técnica como a forma de intervenção do arquiteto e urbanista, acreditava-se que o programa moderno acabaria por ser assumido pelas autoridades. Seriam elas as executoras da nova técnica, da nova arquitetura. Cabia então ao arquiteto e urbanista o estudo, a formulação de soluções ao que se identificava como os problemas das cidades. Le Corbusier afirmava que a autoridade 'surgiria'. A impressão que fica do discurso é que a autoridade se daria conta da importância da proposta modernista e se dirigiria ao técnico, por isso, surgiria, então não havia com que se preocupar.

Mas, eram evidentes aos participantes do Congresso, principalmente para os alemães, as dificuldades de por em prática o programa formulado, considerado realizável tecnicamente e cientificamente correto, mas que pouco tecia considerações sobre as forças políticas necessárias à execução.

Essa dificuldade com a política estava em muito ligada à própria pluralidade política dos arquitetos e movimentos de vanguarda da época, pois como afirma Holston, as críticas por mudanças radicais encontravam reflexo em todas as filiações "entre os 'sindicalistas calatães, coletivistas de Moscou, facistas italianos', e os tecnocratas."

Geralmente voláteis e ambíguas, essas filiações políticas não restringiam a busca dos arquitetos que procuravam qualquer que fosse a autoridade considerada capaz de executar o planejamento total, em qualquer que fosse a forma de governo ou regime, como pontuam Benevolo e Holston.

\footnotetext{
${ }^{68}$ BENEVOLO, Leonardo - História da Arquitetura Moderna - Editora Perspectiva - $3^{\mathrm{a}}$ edição - São Paulo: 1994, p. 508. (LE CORBUSIER apud BENEVOLO)
} 
No caso do Brasil os arquitetos e urbanistas se filiavam ao Estado dito populista, ou ao governante que se comportava como um empreendedor das novas condições necessárias ao urbano. Alguns os exemplos são marcantes na arquitetura brasileira: a equipe composta por vários arquitetos incluindo Lúcio Costa, Oscar Niemeyer, Afonso Reidy entre outros se associa a Gustavo Capanema no Ministério da Educação e Saúde; Oscar Niemeyer a Juscelino Kubitschek no conjunto da Pampulha; Afonso Reidy ao prefeito do Rio Ângelo de Morais no conjunto de Pedregulho; estas entre várias outras associações que visavam incorporar à prática do Estado o pensamento modernista, independentemente das filiações políticas.

Entretanto, independentemente dessa dificuldade interna ao CIAM, fica claro que o partido adotado pelos modernistas dos congressos, não apenas se regia pelas questões econômicas, práticas, técnicas e estéticas, compatibilizando também outro interesse, o da coletividade. Segundo uma interpretação de Nabil Bonduki, em Origens da habitação social no Brasil ao fazer uma referência ao pensamento desses arquitetos e urbanistas, expõe que "o resultado econômico não deveria se desligar da busca de qualidade arquitetônica e urbanística, e da renovação do modo de morar, com a valorização do espaço público." ${ }^{\text {"9 }} \mathrm{O}$ espaço público é o espaço da coletividade.

A produção no Brasil é de considerável qualidade e relevância, alçando os arquitetos e urbanistas ao cenário internacional, numa fórmula de filiação entre política e modernismo que aparentemente dava certo. As produções da Fundação Casa Popular e principalmente dos Institutos de Aposentadoria e Previdência são representativas.

O IV CIAM é importante para o paradigma do programa urbano modernista, resulta dele o documento redigido por Le Corbusier, de forma anônima, em princípio, e depois assumida como síntese do pensamento do Congresso. A Carta de Atenas é um marco constituinte do pensamento do planejamento urbano modernista, representativo por integrar várias das discussões dos congressos precedentes.

O documento procura demonstrar a amplitude dos trabalhos e da análise de 33 cidades da Europa, América do Norte e Ásia, o que seria uma forma de legitimá-lo tecnicamente. Nele,

${ }^{69}$ Essa citação se refere uma análise da postura dos arquitetos dos Institutos de Aposentadoria e Pensão - IAP e do Departamento de Habitação Popular do DF (ainda quando no estado da guanabára) estavam adotando quanto à produção habitacional na qual via claras influencias do CIAM. BONDUKI, Nabil - Origens da habitação social no Brasil. São Paulo: Estação Livre: FAPESP, 1998 p.134 
são pontuadas as diversas discussões dos CIAM anteriores, desde a importância da conscientização das "autoridades", a necessidade de rever o crescimento considerado desordenado, a execução de planos urbanos e distribuição adequadamente igualitária de equipamentos urbanos, à importância do planejamento total como forma de combate ao caos urbano e social na "era do maquinismo", como denominavam.

Assim, uma leitura pontuada da Carta contribui para alguns entendimentos sobre os preceitos dos CIAM, colaborando ainda para o esclarecimento de algumas posições, como a que enfatiza que Brasília é a Carta de Atenas concretizada, e se assim o é, a capital é a resposta a que caos urbano? Havia no Planalto Central alguma desordem urbana a qual Brasília devia responder? Não eram apenas povoados rurais que se encontravam nas terras escolhidas em meio ao Planalto Central? Brasília seria a resposta a quê então? Em outras palavras este trabalho se fia numa interpretação que a capital modernista seria uma resposta a uma pergunta formulada para outro lugar em outro contexto, o que não tira o mérito do urbanismo aplicado, mas sim o discurso a ele vinculado.

Na expressão dada por Le Corbusier impressa na Carta de Atenas "a Cidade é só uma parte de um conjunto econômico, social e político que constitui a região" devendo com isso ser parte integrante de um processo que deve extrapolar o recorte territorial administrativo e levar em conta os elementos constitutivos da região: a geografia do lugar. $E$ por isso, "O plano da cidade é só um dos elementos do todo constituído pelo plano regional."

A conciliação do coletivo com o individual era necessária, para que as ações do grupo, empreendidas sabiamente, fariam "a vida do indivíduo" ser "ampliada e enobrecida". Se, ao contrário, "a preguiça, a estupidez e o egoísmo o assolam, o grupo, enfraquecido e entregue à desordem, só traz a cada um de seus membros rivalidades, rancor e desencanto."

Aqui há um ponto importante de destaque da Carta, quanto ao discurso do CIAM, pois aparentemente só é possível um bom plano se for resultado do coletivo: "um plano é sábio quando permite uma colaboração frutífera, propiciando ao máximo a liberdade individual. Irradiação da pessoa no quadro do civismo". ${ }^{70}$

Impressionantemente e colidindo com a prática que se observa posteriormente do planejamento urbano modernista, como veremos no caso de Brasília, o planejamento do CIAM é por discurso de origem participativa, resultado da coletividade. O projeto para capital foi resultado de concurso, escolhido por técnicos entre várias outras propostas. Participaram

70 LE CORBUSIER, Pseud de Charles Edouard Jeanneret-gris. Carta de Atenas. São Paulo: HUCITEC, 1993. 1 v (Estudos urbanos; 0004), ponto 2 
da escolha representantes internacionais com expertise no assunto, inglês, francês e um representante dos arquitetos do Brasil. Num rito sumário a opção foi feita.

É clara a ênfase ao conhecimento técnico e domínio da técnica pelos arquitetos e urbanistas que são, segundo Le Corbusier ${ }^{71}$, os mais bem preparados para entender o urbano, entender as correlações necessárias entre o físico e as questões sociais, perceber como "a geografia e a topografia desempenham um papel considerável no destino dos homens". Sem jamais esquecer os condicionantes climáticos como sol, ventos, temperatura que encontrarão sua expressão na casa, na aldeia ou na cidade. Por isso não é de se condenar a forma do processo se observada à expertise do urbanista e mesmo porque, inexistia ainda o sujeito de Brasília que pudesse ser consultado, sua verdadeira cara se concretizava com o Estado era para ele a cidade.

Sendo os arquitetos aqueles que são os indicados para a realização do plano das cidades, no entendimento de Le Corbusier, este não deve perder de vista que o plano deve ser maior que a malha urbana da cidade, maior que seu território administrativo, deve ser estudado no conjunto da região de influência a qual faz parte. Na visão modernista do CIAM um plano regional em substituição a um plano municipal, sendo seu limite o raio da ação econômica do aglomerado urbano. Aí se encaixa com perfeição a proposta desenvolvimentista que Brasília marcava.

Ao tratar do Estado e do sistema político, tema de discussões no interior do congresso, e como já citado divergente, se consolida uma interpretação na Carta de Atenas. A forma com que vê a ação governamental, no quinto ponto da carta, não poderia ser mais explicita

"Fenômeno mais variável do que qualquer outro, sinal da vitalidade do país, expressão de uma sabedoria que atinge seu apogeu ou já toca seu declínio. Se a política é de natureza essencialmente variável, seu fruto, o sistema administrativo, possui uma estabilidade natural que Ihe permite, ao longo do tempo, uma permanência maior e não autoriza modificações muito freqüentes. Expressão da dinâmica política, sua duração é assegurada por sua própria natureza e pela própria força das coisas. É um sistema que, dentro de limites bastante rígidos, rege uniformemente o território e a sociedade, impõeIhes seus regulamentos e, atuando regularmente sobre todos os meios de comando, determina modalidades uniformes de ação em todo o país. Esse quadro econômico e político, cujo valor embora tenha sido confirmado pelo uso durante um certo período, pode ser alterado a qualquer instante em uma de suas partes, ou em seu conjunto. Algumas vezes, basta uma descoberta científica para provocar uma ruptura de equilíbrio,

\footnotetext{
${ }^{71}$ LE CORBUSIER - Planejamento urbano
} 
para fazer surgir a incompatibilidade entre o sistema administrativo de ontem e as imperiosas realidades de hoje. Pode ocorrer que algumas comunidades, que souberam renovar seu quadro particular, sejam asfixiadas pelo quadro geral do país. Este último pode, por sua vez, sofrer diretamente a investida das grandes correntes mundiais. Não há quadro administrativo que possa pretender a imutabilidade. ${ }^{, 72}$

Expõe dois argumentos, sendo que o primeiro está na materialidade do Estado que busca sua reprodução interna longe das instabilidades políticas, uma interpretação da tecnocracia como um bloco no poder.

O outro argumento quer então induzir a um pensamento onde o conhecimento técnicocientífico seja capaz de alterar a própria composição e ação do Estado, em uma acepção que o conhecimento técnico-científico é revolucionário. Isso é fundamental ao se observar o movimento moderno, pois busca atribuir à arquitetura e ao urbanismo uma capacidade de transformação social. Gramsci discordaria da proposição de Le Corbusier, pois não é o quadro administrativo que determina a sociedade, ele é mutável, sem necessariamente mudar as formas de reprodução de uma sociedade. Mas esse argumento é preciso sobre a idéia que se fazia de Brasília.

Esse clima de mudança, que se manifesta no documento busca seduzir aqueles que o lêem. Uma situação de eterno movimento para o desenvolvimento humano;

"tudo é movimento. À medida que o tempo passa, os valores indubitavelmente se inscrevem no patrimônio de um grupo, seja ele cidade, país ou humanidade; a vetustez, não obstante, atinge um dia todo conjunto de construções ou de caminhos. A morte atinge tanto as obras como os seres.",73

E no entendimento expresso no documento, a modernidade, que é base do CIAM, é por contradição, no sistema capitalista, geradora de uma crise colossal e rápida que se via espraiando pelo mundo. É na era do maquinismo, como denominavam, que o caos das cidades é criado, subvertendo as condições de trabalho, rompendo com o que identifica como:

"um equilíbrio milenar, aplicando um golpe fatal no artesanato, esvaziando o campo, entupindo as cidades e, ao desprezar harmonias seculares, perturbando as relações naturais que existiam entre a casa e os locais de trabalho. Um ritmo furioso associado a uma precariedade desencorajante desorganiza as condições de vida, opondo-se ao

\footnotetext{
${ }^{72}$ LE CORBUSIER, 1993, ponto 5

${ }^{73}$ LE CORBUSIER, 1993, ponto 7
} 
ajuste das necessidades fundamentais. As moradias abrigam mal as famílias, corrompem sua vida íntima, e o desconhecimento das necessidades vitais, tanto físicas quanto morais, traz seus frutos envenenados: doença, decadência, revolta. O mal é universal, expresso, nas cidades, por um congestionamento que as encurrala na desordem e, no campo, pelo abandono de numerosas terras. ${ }^{74}$

A industrialização da sociedade gerando o considerado caos urbano. Centros urbanos congestionados, edificações inadequadas à moradia, a falta de espaços verdes, população empobrecida "incapaz de adotar, por si mesma, medidas defensivas". A que se notar que no Brasil o processo ocorre em conjunto: industrialização por meio do Plano de Metas, do "50 anos em 5" e a realização urbana da resposta modernista ao caos causado pela industrialização. Essa preocupação em antever a resposta aos problemas que supostamente irão surgir e que ainda nem mesmo foram formulados, tendo em vista que a realidade a que se inseririam ainda não havia ocorrido, tem peso e importância como formadora de discurso ideológico.

Mesmo assim algumas preocupações são procedentes, ao passo que as áreas com melhores condições, as mais favorecidas, de insolação, ventilação, em espaços com vistas cenográficas, segundo o próprio discurso, "são geralmente ocupadas pelas habitações de luxo; prova-se assim que as aspirações instintivas do homem o induzem, sempre que seus recursos the permitem, a procurar condições de vida e uma qualidade de bem estar cujas raízes se encontram na própria natureza", as áreas com as piores condições são geralmente ocupadas pelas sub-habitações.

Como Villaça ainda aponta, não são apenas esses os critérios, a localização tem também aspectos importantes quanto à infra-estrutura, proximidade aos centros de comércio e decisão.

"A localização se apresenta assim como um valor de uso da terra - dos lotes, das ruas, das praças, das praias - valor que, no mercado, se traduz em preço da terra. Tal como qualquer valor, o da localização também é dado pelo tempo de trabalho socialmente necessário para produzi-la, ou seja, para produzir a cidade inteira da qual a localização é parte. ${ }^{775}$

Na proposição modernista é reconhecida a importância do zoneamento como instrumento

\footnotetext{
${ }^{74}$ LE CORBUSIER, 1993, ponto 8

${ }^{75}$ VILLAÇA, Flávio. Espaço Intra-Urbano no Brasil. São Paulo: Studio Nobel: FAPESP: Lincoln Institute, 2001 p.72
} 
de exclusão social e segregação espacial. Vale observar que existe um pensamento consciente dos instrumentos de controle social que ronda o discurso modernista da Carta de Atenas. Em muitos estudos sobre o urbano, vários destes pontos são recorrentes. Não é surpreendente então a força que esse documento ainda exerce sobre uma quantidade considerável de arquitetos e urbanistas.

A definição de zoneamento não poderia ser mais clara, descrita assim no ponto 15 :

"O zoneamento é a operação feita sobre um plano de cidade com o objetivo de atribuir a cada função e a cada indivíduo seu justo lugar. Ele tem por base a discriminação necessária entre as diversas atividades humanas, cada uma das quais reclama seu espaço particular: locais de habitação, centros industriais ou comerciais, salas ou terrenos destinados ao lazer. Mas se a força das coisas diferencia a habitação rica da habitação modesta, não se tem o direito de transgredir regras que deveriam ser sagradas, reservando só para alguns favorecidos da sorte o benefício das condições necessárias para uma vida sadia e ordenada. É urgente e necessário modificar certos usos. É preciso tornar acessível para todos, por meio de uma legislação implacável, uma certa qualidade de bem-estar, independente de qualquer questão de dinheiro. É preciso impedir, para sempre, por uma rigorosa regulamentação urbana, que famílias inteiras sejam privadas de luz, de ar e de espaço." (grifo nosso)

O discurso não elimina o uso do instrumento, pelo contrário, exige que regulamentações mais rigorosas possibilitem que seja cumprido um zoneamento, e este deve ser mais justo com os menos favorecidos. Descreve-se, assim, o pensamento primordial do planejamento moderno que é a segregação ${ }^{76}$, dada por uma rigorosa determinação de usos e ocupação do solo.

O que aparentemente se busca com isso é a qualificação dos espaços urbanos com a adoção de uma regulação rigorosa, tendo em vista a distribuição, também, dos equipamentos urbanos necessários ao bem-estar social. Na determinação da Carta, usos devem ser segregados, mas o acesso a eles deve ser garantido, como descrito no ponto. Os equipamentos de uso coletivo, como os destinados à educação, saúde e lazer, devem estar mais vinculados às habitações.

Quanto ao que se identifica como subúrbios, regiões consideradas no documento como "resíduo" das cidades, periféricos a elas, sendo portanto "um erro urbanístico, disseminado por todo o universo e levado às suas conseqüências extremas na América. Ele se constitui

\footnotetext{
${ }^{76}$ Utiliza-se aqui segregação como ato consciente de separação, apartação, discriminação de parcela do território, para determinado fim ou função.
} 
em um dos grandes males do século", no qual a função tempo-distância é uma difícil questão sem solução adequada. E mesmo quando levados a criar uma visão bucólica, mesmo que em alguns casos se procure fazer cidades-jardins, são estes "paraísos ilusórios", "solução irracional", reproduzidos.

$\mathrm{Na}$ visão da Carta de Atenas, os bairros residenciais devem ocupar as melhores localizações do espaço urbano, tendo em vista o clima, a insolação, em situações que se atenda ao que se identifica como as "leis de higiene universalmente reconhecidas", inseridas áreas esportivas, com densidades controladas tendo em vista as formas de habitação. $A$ escolha do território do Distrito Federal, com $5.802 \mathrm{~km}^{2}$, responde a essa condição geográfica e climatológica em toda sua extensão, pois é em um planalto que se insere, e assim todo ele é adequado ${ }^{77}$.

Nesses bairros residenciais, nenhuma das edificações marca e define o espaço da rua, não sendo aconselhável até mesmo sua comunicação direta, buscando minimizar o conflito existente. $O$ urbanismo que se propõe estabelece a idéia da edificação isolada, tendo todo seu perímetro livre, liberando-se ao máximo o solo para a circulação de pedestres e para os espaços verdes, onde também devem ocorrer as áreas destinadas ao lazer dos habitantes.

Nesses espaços intersticiais de edifícios estariam, também, os jardins de infância, escolas, centros juvenis e todas as construções de uso comunitário intimamente ligadas ao uso habitacional.

Marca-se novamente que nas relações entre o morar e o trabalhar, o diagnóstico da IV CIAM, representado pela Carta de Atenas, identifica o que considera percursos desmesurados em alguns casos, com uma rede viária de transporte aquém da necessária principalmente em horários específicos. A resposta na capital foi dada nas estruturas rodoviárias, que alguns identificam como autopistas.

Ainda, declara que a falta de um programa urbano provoca o crescimento descontrolado das cidades, propiciando a instalação de usos de forma indiscriminada, o que motiva a especulação imobiliária que não encontra regulação adequada para a atuação do mercado imobiliário. Ressalta-se que há ainda pouco estudo sobre o tema para a cidade planejada modernista capital federal, tendo em vista o cenário que se constituiu o aglomerado urbano.

\footnotetext{
${ }^{77}$ Obviamente aqui se faz uma ressalva quanto às questões ambientais, como áreas de proteção de mananciais. Contudo a extensão das terras propícias a ocupação urbana ainda é consideravelmente grande.
} 
Dessas observações quanto ao programa urbano, a Carta propõe que as distancias entre trabalho e moradia sejam sempre reduzidas ao mínimo necessário para o bom funcionamento dessas duas. E ainda, entende que as indústrias devem ser colocadas próximas às rotas e infra-estruturas rodoviárias, ferroviárias e fluviais, facilitando seu abastecimento e a distribuição do produto das mesmas.

Neste caso, deve existir uma independência, uma faixa de amortecimento, entre o setor industrial e um setor habitacional. Uma zona verde separa estes dois setores que se encontrariam paralelos.

$\mathrm{Na}$ concepção do CIAM, a morte de uma economia baseada no artesanato deve ser combatida:

"O artesanato, por sua natureza, difere da indústria e requer disposições apropriadas. Ele emana diretamente do potencial acumulado nos centros urbanos. $O$ artesanato de livros, joalharia, costura ou moda encontra na concentração intelectual da cidade a excitação criadora que the é necessária. São atividades essencialmente urbanas e, portanto, os locais de trabalho, poderão ficar situados nos pontos mais intensos da cidade. ${ }^{, 78}$

O artesanato descrito pelo CIAM não é parte integrante do comércio geral e das atividades de prestação de serviço, é uma atividade específica, com grande carga cultural e, por isso, altamente especializado. É categoria própria, diferentemente do que se observa hoje como classificação de atividade econômica. Há então uma dificuldade de fundo em perceber a dinâmica econômica industrial, capitalista ou não. A indústria deve existir, mas deve preservar o artesão. É curioso notar uma condição invertida na capital, o artesanato só surge com a urbanização, na verdade um artesanato precedente à instauração da capital é desconhecido.

Na leitura do contexto econômico urbano, outro cuidado deve ser tomando com relação ao que foi considerado como o centro de negócios, destinado à administração privada ou pública. A esse centro devem ser garantidas comunicações diretas, sendo as mesmas que atendam aos setores habitacionais, industriais, do artesanato e da administração pública. Ficando preferencialmente na confluência das vias. No caso da capital a implantação dessa comunicação é tão exagerada que se divide o centro em quatro. $O$ cruzamento dos eixos implode o centro da cidade.

Como pode se notar a circulação torna-se chave da proposição do CIAM que, querendo ou

\footnotetext{
${ }^{78}$ LE CORBUSIER, 1993, ponto 49
} 
não, ao setorizar a cidade modernista, impõe um sistema de circulação mais definido, próprio ao deslocamento das "novas máquinas", os automóveis. De forma que esse novo elemento do planejamento deve ocorrer mediante análises e estatística rigorosas sobre o conjunto da cidade e sua região, "trabalho que revelará os leitos de circulação e a qualidade de seus tráfegos."

O resultado dessa premissa deve levar em conta então, segundo expresso na Carta, uma classificação da circulação conforme sua natureza, em função dos veículos e velocidades, prevendo-se também que esse tráfego se desenvolva de forma contínua admitindo para seu franco funcionamento mudanças de nível, evitando-se cruzamentos.

Há ainda um ponto importante quanto à circulação, a distinção entre veículo e pedestre. Ao pedestre deve ser garantida circulação diferenciada e sendo esta uma medida fundamental para esse novo urbanismo que se estabelece pelos preceitos da Carta de Atenas. Prescreve como exigência que poderia ser "considerada tão rigorosa quanto aquela que, no domínio da habitação, condena toda orientação da moradia para o norte". Mesmo que para as regiões mais ao sul do equador o inverso pode valer, uma condenação não faz grande sentido, já que soluções simples sempre existem, nossos alpendres são uma bela solução.

A Carta de Atenas nos revela a preocupação dos arquitetos modernistas do CIAM, e sua dificuldade em perceber e se ajustar a uma nova dinâmica urbana que vai se consolidando. Suas observações são oriundas de quadro considerado por eles caótico, desordenado fadado à completa desestruturação das sociedades.

$E$, como isso tem influência num país onde se observa que o contexto em que foi inserida a nova capital era de formação de uma sociedade que se pretendia capitalista. A desestruturação na qual se preocupavam era resultado de uma sociedade urbano-industrial. No Brasil, a implementação do planejamento total preconizado pelos modernistas do CIAM ocorre durante o processo de mudança da sociedade rural, por meio da transposição drástica a uma sociedade urbana, na tentativa de proletarização do campesinato "a fórceps", arrancando-lhe do meio rural e o abandonando num meio urbano ainda em formação.

Portanto, duas considerações parecem oportunas: a primeira é que, no Brasil, a fórmula aparentemente está deslocada, pois aqui uma industrialização absolutamente bancada pelo Estado estava em curso, diferentemente dos países centrais da Europa e América do Norte que já haviam enfrentado as revoluções industriais; segundo, no âmbito do CIAM, lançar um documento aparece como uma saída importante, um manifesto, uma forma de divulgar um ideário construído durante 5 anos de discussões.

Outro aspecto digno de nota tem a ver com um objetivo mais socializante, mais socialista. 
Consideravam importante combater um fato que vinha se consolidando "desde o começo da era do maquinismo, o crescimento incessante dos interesses privados", este representado principalmente pelo mercado imobiliário, mas não apenas ele. No ponto 73 , diz o documento:

"A violência dos interesses privados provoca um desastroso desequilibrio entre o ímpeto das forças econômicas, de um lado, e, de outro, a fraqueza do controle administrativo e a impotente solidariedade social."

Clamam em meio ao documento por uma intervenção do Estado no desenvolvimento e crescimento das cidades conduzido "sem precisão nem controle e sem que sejam levados em consideração os princípios do urbanismo contemporâneo atualizados aos meios técnicos qualificados."

No entendimento desses arquitetos, os meios técnicos e o saber estavam já à disposição. Devidamente estudados por técnicos, estes meios são a forma adequada de lidar com a cidade em franco crescimento. Mas para isso era

"preciso fazer com que sejam admitidos pelos órgãos administrativos encarregados de velar pelo destino das cidades e que, não raro, são hostis às grandes transformações propostas por esses dados novos. É necessário, antes de mais nada, que a autoridade seja esclarecida e, depois, que ela aja. Clarividência e energia podem vir a restaurar a situação comprometida."

A dimensão-chave corbusiana, e de todo esse novo urbanismo, era o homem e sua escala. "O dimensionamento de todas as coisas no dispositivo urbano só pode ser regido pela escala humana", a medida natural do homem, a medida biológica serviria de base a todas as escalas que estarão relacionadas à vida urbana e às diversas funções do ser. Ou seja, a partir de uma antropometria se organizaria o mundo urbano, a moradia, o trabalho, as distâncias, a relação com a natureza e sua biologia. Seriam admitidas as condições de tempos para dormir, para trabalhar e para o lazer.

Surgem desse homem e dessa visão de organização do mundo urbano os quatro fundamentos basilares do modernismo do CIAM: habitar, trabalhar, recrear-se (nas horas livres) e circular.

O homem que começa a compor o urbano no Brasil da década de 50 , o sujeito urbanoindustrial recente na história brasileira, é o migrante que, em grande parte das vezes, tem outro tipo de relação. Não é urbano por vivência, é rural em suas relações com o espaço e com a coletividade, e assim pode-se dizer que não tem as mesmas relações espaciais com o mundo que the cerca se comparado com aquele que teve suas relações mediadas pelo mundo dos centros industriais em formação. 
A cidade modernista é então organizada a partir das quatro funções-chave de forma autônoma em:

"territórios e locais para cujo equipamento e instalação serão acionados todos os prodigiosos recursos das técnicas modernas. Nessa distribuição, serão consideradas as necessidades vitais do indivíduo e não o interesse ou o lucro de um grupo particular. $O$ urbanismo deve assegurar a liberdade individual e, ao mesmo tempo, favorecer e se aproveitar dos benefícios da ação coletiva."79

A circulação é crucial dentro da concepção do programa moderno, já que garante o que é identificado com o ciclo das funções cotidianas citadas, buscando a otimização do tempo, sendo mais uma vez a habitação o centro da preocupação do discurso moderno do CIAM. A partir dela se faz a observação do tempo de deslocamento, atendidas o que identificavam como as "novas velocidades mecânicas". A solução modernista do CIAM admite que é por meio do controle de trafego e da hierarquização de velocidades que se encontra a otimização do tempo.

O programa urbano é de incumbência dos especialistas que com base em análises rigorosas, prevê as etapas no tempo e no espaço da execução, observados os recursos naturais do sítio, a topografia, os dados econômicos, as necessidades sociológicas, os valores espirituais, tendo como medida espacial a escala humana. Essa escala se expressa no que os CIAM primordialmente se ocuparam: a célula habitacional.

A menor unidade do urbanismo modernista preconizado pela Carta de Atenas é uma unidade habitacional com proporções adequadas: "a casa é o núcleo inicial do urbanismo", é a primeira das funções que merece atenção do urbanismo. O trabalho e o lazer vêm a reboque. Focando o momento da adoção do planejamento total do CIAM no Brasil, ou mesmo o pensamento moderno em sua concepção mais generalizada, novamente surge o ponto entre o recém chegado do campo e suas relações com o ambiente urbano, já que seu entendimento com a terra e a casa é outro, até mesmo com o trabalho e o lazer. O trabalho se pauta na subsistência e não em mercadoria que permite uma relação de troca.

Le Corbusier e os modernistas do CIAM acreditam ser imprescindível para essa realização a utilização dos recursos técnicos mais modernos que, estando à disposição dos especialistas, revolucionam o estado das cidades. Para que essa revolução urbana ocorra, Le Corbusier acreditava na necessidade de uma ação política referenciada em:

"um poder político tal como se o deseja, clarividente, convicto, decidido a realizar as

\footnotetext{
${ }^{79}$ LE CORBUSIER, 1993, ponto 81
} 
melhores condições de vida, elaboradas e expressas nos planos; uma população esclarecida para compreender, desejar, reivindicar aquilo que os especialistas planejaram para ela; uma situação econômica que permita empreender e prosseguir os trabalhos, alguns dos quais serão consideráveis. Pode ser, todavia, que mesmo em uma época em que tudo caiu ao nível mais baixo, em que as condições, políticas, sociais e econômicas são as mais desfavoráveis, a necessidade de construir abrigos decentes apareça de repente como uma imperiosa obrigação, e que ela venha dar ao político, ao social e ao econômico o objetivo e o programa coerentes que justamente lhes faltavam. ${ }^{\text {'80 }}$ (grifo nosso)

E por meio disso, seria a arquitetura que presidiria os destinos da cidade, ordenando a moradia, tecnicamente dimensionada, a qual buscaria liberar ao máximo o solo, uma arquitetura organizadora do espaço urbano, o edifício que definiria o espaço e não mais a parcela do solo destinada ao lote. Seria então a arquitetura a grande responsável pelo bemestar e beleza das cidades, distribuindo os diferentes elementos construídos numa proporção harmoniosa, já que se fundava na escala humana. "A arquitetura é chave de tudo".

A clarividência do poder político que concretiza a nova capital estava toda ela voltada na na formação do Estado moderno, na motivação para a estruturação de uma economia de mercado interno via industrialização por substituição de importações, num processo que procurava queimar etapas de desenvolvimento. Ignorava, ou melhor, era secundária em sua agenda uma política fundiária a qual representava um obstáculo complexo a ser enfrentado.

O parcelamento do solo destinado à propriedade privada é um dos fatores a serem enfrentados, e, por isso, primordial no fundamento do programa moderno. Ernest May, um dos arquitetos modernos mais experientes no enfrentamento da questão da moradia, com sua experiência em Frankfurt, pautou boa parte das discussões do III CIAM quanto à concepção do que acabou por se tornar, como Le Corbusier descreve, a célula do urbanismo. May era um dos maiores defensores das soluções práticas e via na propriedade fundiária privada um dos nós da questão moderna.

A resposta do IV CIAM a esta questão era a regulação do solo urbano, de forma que o interesse privado fosse subordinado ao interesse público. Era então preciso um poder político engajado no ideário modernista para alterar o quadro vigente naquele momento.

Bonduki vê uma substancial diferença na base de atuação dos arquitetos modernistas,

\footnotetext{
${ }^{80}$ LE CORBUSIER, 1993, ponto 91
} 
considerados de vanguarda.

"Se na Europa a perspectiva da vanguarda estava em boa parte associada aos ideais socialistas, no Brasil ela se vinculou ao desenvolvimentismo. Com diferentes objetivos políticos, militava-se por uma Neue Wohnkultur, uma nova cultura do morar., ${ }^{, 81}$

Essa percepção da habitação na forma defendida pelo CIAM, ou seja, a tese de Ernest May do II CIAM em Frankfurt, segundo Bonduki, no Brasil, teve sua primeira divulgação no I Congresso de Habitação realizado em São Paulo, no ano de 1931, sendo no mesmo ano assimilada ao programa de ensino da Escola Nacional de Belas Artes, devido à renovação curricular introduzida por Lúcio Costa.

O conceito presente em "Wohnung für das existenz-minimum", (casa projetada para o mínimo existencial), se difunde entre os arquitetos brasileiros influenciando enormemente a produção de moradias.

Soma-se a isso as características absolutamente distintas da sociedade européia com relação à brasileira, do ponto de vista econômico e da organização política administrativa. A primeira, em pleno desenvolvimento de uma política voltada à consolidação de um Estado do Bem Estar Social, na qual o capitalismo já havia sido implementado a mais de um século. A segunda sociedade em um momento de realização e constituição de uma sociedade urbana, um mercado consumidor em um processo de implementação da indústria com características absolutamente divergentes.

Assim, a influência das discussões e documentos dos primeiros quatro Congrès Internationaux d'Architecture Moderne, se faz tanto em termos do urbanismo e do planejamento urbano da Carta de Atenas e dos escritos de Le Corbusier, como também das discussões quanto aos parâmetros mínimos para moradia e sua capacidade de reprodução, presente nos documentos dos II e III CIAM. A influência da experiência do grupo alemão Der Ring com Ernest May, Walter Gropius, Taut, Wagner e outros é fato.

\subsubsection{Concepção urbanística de Brasília}

O planejamento para a nova capital não se inicia com o concurso de Brasília, ou com a decisão do governo de Juscelino Kubitschek. O histórico desse planejamento vem de longo prazo, como já apresentado, e tampouco se restringiu à escolha de sítios mais bem

\footnotetext{
${ }^{81}$ BONDUKI 1998, p. 144.
} 
preparados, com boas condições topográficas, geológicas, geográficas e ambientais.

A decisão de "transpor" a capital, a forma de concretizar o projeto urbanístico e o planejamento urbano identificado em Brasília guardam, em muito, similaridade com a forma concreta do Estado brasileiro. Arrisca-se até em afirmar que, no planejamento urbano modernista brasileiro vemos a própria noção de modelo de Estado adotado e as reproduções de uma série de relações sociais, com as quais não devia, em princípio compactuar.

Inicia-se a obra sem projeto urbanístico, sem a propriedade fundiária resolvida como veremos adiante, apenas projetos arquitetônicos espalhados. A casa do líder do Estado moderno brasileiro em plena construção, próxima a um lago artificialmente construído e um hotel a 600 metros dessa casa. O Palácio da Alvorada de Oscar Niemeyer é projeto de 1956, o Plano Piloto de Brasília de Lúcio Costa é de 1957. Há quem se arrisque a dizer que a posição do Palácio é que definiu a altitude da lâmina do Lago Paranoá.

É por essa incrível antecipação da obra em detrimento ao projeto urbanístico e sua concepção, que mais uma vez põe em perspectiva o grau de importância do urbano em relação aos interesses que geraram Brasília. Principalmente por parte de arquitetos e urbanistas há uma comum inversão da importância do "projeto de país" em detrimento do "projeto da cidade", mesmo que apreendida como a capital que concretizaria a cara do país moderno.

Apesar de sua extraordinária concretização de vários elementos do urbanismo moderno no Plano Piloto de Lúcio Costa, não foi o movimento modernista que produziu a idéia de uma nova nação e de uma nova capital, ele se apropriou do momento, sendo confiada aos representantes desse movimento pela autoridade constituída, no governo de JK, a oportunidade única de concretizar suas aspirações. O modernismo não é o princípio que mudou o Brasil, mas a concepção urbana que participou da construção do Brasil atual.

Entretanto, colocando a concepção urbana em seu lugar, é importante avaliar sua relação na formação do espaço social de Brasília e em que seus princípios influíram. Portanto, ao observar o projeto do Plano Piloto de Brasília de Lúcio Costa, é interessante destacar que, segundo Francisco Leitão, não existe dúvida quanto "à impossibilidade de se identificar um momento histórico concreto quando o detalhamento do PPB de Lúcio Costa possa ser considerado 'acabado' ou 'definitivo'. Ao contrário, os dados corroboram (...) que o desenvolvimento se deu de maneira processual e gradativa" ${ }^{82}$. De forma que nunca houve

\footnotetext{
${ }^{82}$ LEITÃO, Francisco das Chagas.
} 
um processo encerrado em etapas, a concretização do projeto ocorre durante a materialização da obra, projeto e execução ocorrem tendo em vista o canteiro e as decisões políticas, administrativas e financeiras.

Assim, uma interpretação na qual conjuga a participação expressiva de diversos co-autores/ executores, pensamentos e projetos urbanísticos, como que absorvidos no processo de execução do projeto urbanístico e na construção da capital ganha força. Segundo Antônio Carlos Carpintero, podemos verificar alterações conceituais importantes como a reintrodução do "lote urbano como elemento jurídico e físico de propriedade" ${ }^{83}$, no caso da linha de casas das quadras 700 na W3 que percorre de norte a sul os setores de habitação coletiva, sendo esta última a que representava a unidade urbana a ser reproduzida. A unidade unifamiliar não participava, não era prevista na proposta primordial de Lúcio Costa.

Essa alteração não pode ser considerada inexpressiva devido à sua restrita ocupação, pois, nas superquadras o urbanismo dos lotes tradicionais dava lugar ao que se convencionou denominar de projeção. A projeção, que nada mais é, em termos morfológicos, que a projeção do edifício no terreno, representa fator inovador para o padrão de urbanização a ser reproduzido em toda a cidade, onde o térreo é liberado pelos pilotis, passando este a integrar o espaço de trânsito público, e o de passagem entre o público e o privado, determinando uma nova relação coletiva onde o espaço do térreo é de posse privada, mas de domínio público.

E isso só era possível com a massificação da construção por meio das habitações coletivas. É nesse ponto que o Plano de Lucio Costa se filia aos pensamentos expressos nos CIAM, onde há um destaque quanto à importância dos espaços coletivos e públicos.

Carpintero ainda menciona os notáveis vínculos com o esquema da cidade-linear de Soria y Mata, e com a cidade-jardim de Ebenezer Howard, o que representa, em sua análise, filiações teóricas que nada têm em comum com os CIAM. Para este autor, a base conceitual sobre a qual se estrutura a cidade, a estrutura física, é linear, é o esquema de Soria y Mata para Madri.

A proposta de Arturo Soria y Mata é tão radical por buscar romper com a estrutura concêntrica comum as cidades, a qual, na visão desse engenheiro, reforçava um padrão perverso de centro periferia. Na cidade linear de Soria y Mata é ao longo de um eixo de

\footnotetext{
${ }^{83}$ CARPINTERO, Antônio Carlos Cabral. Brasília: Prática e Teoria Urbanística no Brasil, 1956 - 1998. tese de doutoramento, São Paulo FAU-USP, p.
} 
transporte metroviário ${ }^{84}$ que se desenvolveriam todas as atividades da cidade. Essa concepção marca um importante padrão de desenvolvimento projetual presente no projeto do Plano Piloto.

FIGURA I Proposta Traçado de subúrbio Linear para Subúribio de Madri. de Arturo Soria y Mata

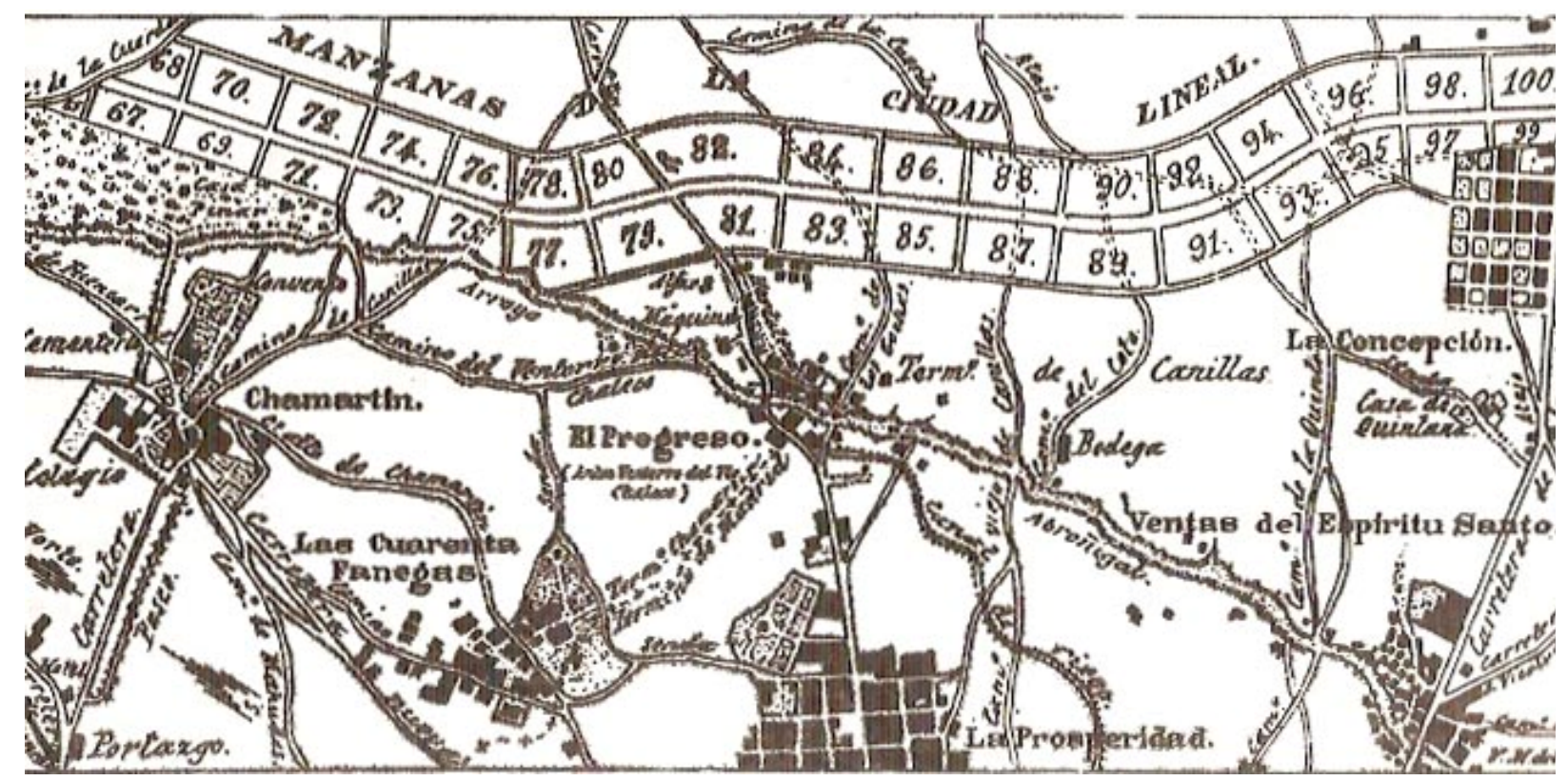

Fonte: BENEVOLO, Leornado. História da Arquitetura Moderna. São Paulo: Editora Perspectiva, 3a edição, 1994.

Há uma clara adequação dos esquemas funcionais da Carta de Atenas ao desenho da cidade-linear, afinal a cidade se desenvolve ao longo do Eixo Rodoviário e as funções são colocadas ordenadamente sobre ele.

Quanto às quadras residenciais, as Superquadras, em conjunto com todos os outros elementos que compõe o que Lúcio Costa denominou de unidade de vizinhança, são a expressão da cidade-jardim de Howard, dada sua imagem imediata, obviamente relidas. Carpintero mantém essa interpretação buscando uma origem.

"A idéia de unidade de vizinhança, foi desenvolvida por Clarence Stein na década dos vinte deste século $(X X)$, que deriva da cidade-jardim. Lúcio Costa usou de fato esta idéia como base para estruturação do problema habitacional.

Usou também o esquema de propriedade, mantendo públicos os terrenos nas quadras.

\footnotetext{
${ }^{84} \mathrm{Na}$ proposta de Arturo Soria y Mata, se propõe um sistema de ferrovia elétrica, próxima ao que se convencionou como bonde, e ou o metrô. Fez a opção pela designação de metrô.
} 
E, mais que tudo, usou uma imagem visual ambígua, entre campo e cidade, que se tornou a marca principal da paisagem de Brasília. Isto é o cerne da proposta de Howard: os três imãs: cidade, campo e campo-cidade.,85

Resgatando também as preocupações de Matheus Gorovitz, que busca demonstrar que existem diferenças na concepção do urbano entre Le Corbusier e Lúcio Costa, por meio do que considera como a categoria da escala, afirmando que "o conceito de escala foi elemento-chave utilizado na definição do partido urbanístico de Brasília" ${ }^{66}$

Em sua argumentação, Gorovitz demonstra que os conceitos dos dois urbanistas para a categoria são diferentes, o que distancia as proposições, mas é inegável que a proposta viária é toda derivada do CIAM, sendo este o elemento estruturador da cidade.

Não é intenção desse trabalho fazer uma análise profunda dos fatores influentes no pensamento de Lúcio Costa ao apresentar seu partido urbanístico para o Plano Piloto da capital federal, mas marcar que em sua concepção existiram muito mais influências do que apenas os escritos do CIAM.

O urbanismo proposto por Lúcio Costa reflete não só os princípios da arquitetura moderna dos CIAM, mas, antes disso, procura apresentar uma interpretação resultante da própria formação do autor do plano. Segundo Gorovitz ${ }^{87}$, Costa parte de uma interpretação distinta, por exemplo, da categoria "escala humana" corbusiana expressa na Carta de Atenas onde

“(...) a medida natural do homem deve servir de base a todas as escalas que estarão relacionadas à vida e às diversas funções do ser. Escala das medidas, que se aplicarão às superfícies ou às distâncias; escala das distâncias, que serão consideradas em sua relação com o ritmo natural do homem; escala dos horários, que devem ser determinados considerando-se o trajeto cotidiano do sol.,p88

$\mathrm{Na}$ interpretação de Gorovitz, há uma contraposição no conceito de Lúcio Costa que privilegia a escala do homem enquanto ser cultural, ao de Corbusier de homem como ser natural expresso na Carta de Atenas. Essa contraposição, segundo esse autor, garante ao projeto do Plano Piloto de Brasília a superação de "uma etapa representada pelas teses

\footnotetext{
${ }^{85}$ CARPINTERO, 1998, pg. 131

${ }^{86}$ GOROVITZ, 1985 pg 63

${ }^{87}$ GOROVITZ, Mateus - Brasília, uma questão de escala. Projeto: São Paulo, 1985

${ }^{88}$ Idem, p.
} 
funcionalistas do CIAM,89

FIGURA II Projeto de Lúcio Costa apresentado para o concurso do Plano Piloto de Brasília - 1957

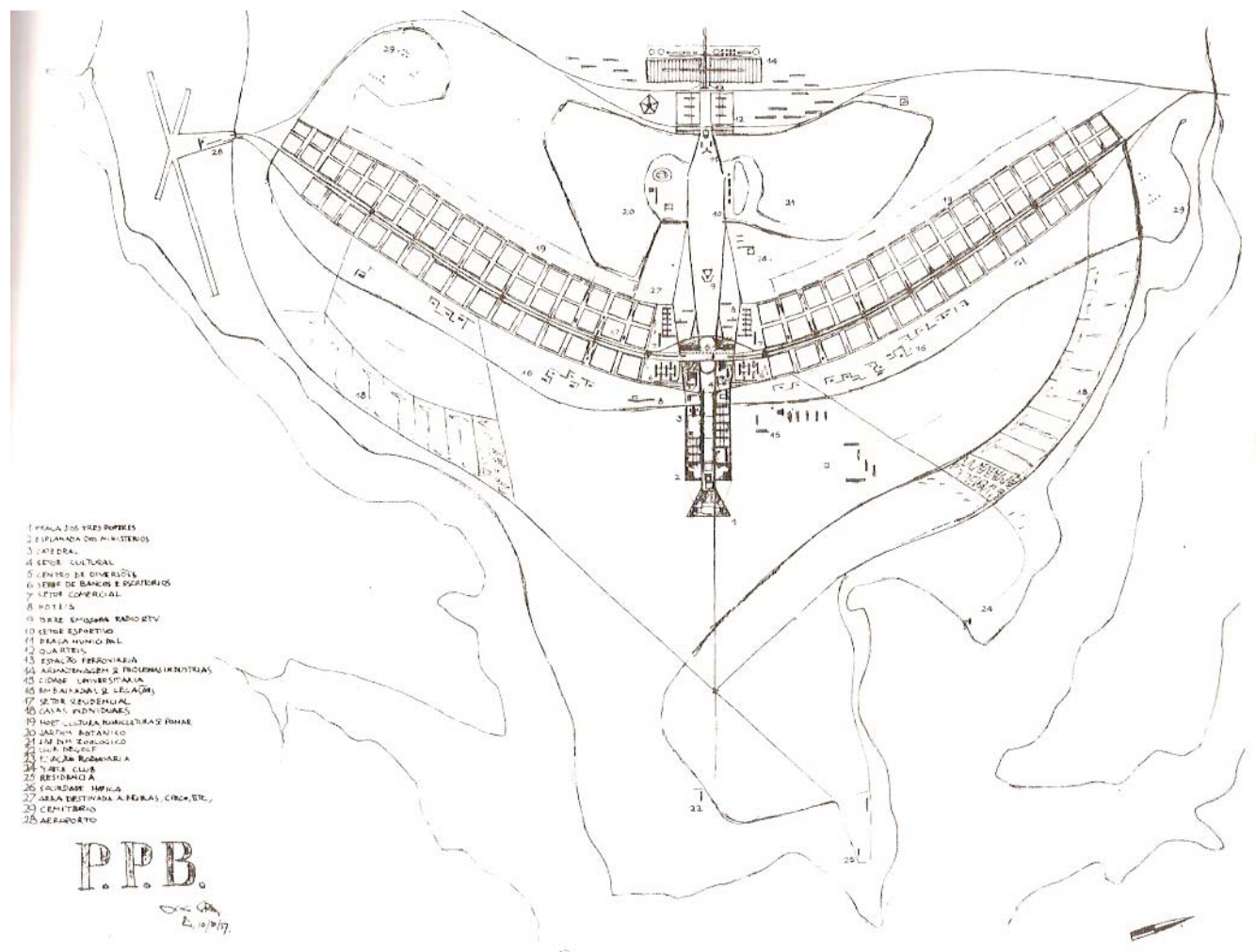

Fonte: Relatório do Plano Piloto - Lúcio Costa/1957

Essa interpretação não interpõe mudança à observação que se faz, pelo senso comum, de que Brasília seria a própria materialização dos preceitos da Carta de Atenas, o que se media é a influência e a contribuição de outras concepções urbanísticas no projeto do Plano Piloto. Para Carpintero, representa uma concepção absolutamente brasileira, devido à sua síntese de influência, o que a tipificaria como diferenciada de outras idéias.

Para se observar o que Lúcio Costa definiu como escalas a serem adotadas no projeto do Plano Piloto, segue a descrição de cada uma delas:

Escala residencial: é a escala onde se faz o cotidiano, que se configura ao longo das alas Sul e Norte do Eixo Rodoviário. Estrutura-se na forma de superquadras residenciais, com tipologias de seis ou três pavimentos ${ }^{90}$ sobre pilotis, cercadas em todo seu perímetro, por

${ }^{89}$ GOROVITZ, 1985, pg71

${ }^{90}$ Aqui a distinção entre as Superquadras identificadas como 100,200 e 300, com edifícios de seis pavimentos e pilotis e as superquadras identificasas nas $400 \mathrm{com}$ três pavimentos e pilotis. 
densa faixa arborizada, e alternadas por entrequadras, com comércio local e equipamentos comunitários de vizinhança, configurando uma maneira própria de viver de Brasília. A proporção das edificações (seis pavimentos) em muito guarda estética nas alturas das edificações da rue de Hausmann.

Escala monumental: é aquela concebida para conferir à cidade a marca efetiva de capital do País, estando configurada pelo Eixo Monumental, desde a Praça dos Três Poderes até a Praça do Buriti, incluindo os edifícios públicos e os espaços entre eles, assim como os monumentos cívicos que integram esse espaço, guarda-se aqui uma proximidade com elementos simbólicos de terraplenos. É o espaço do poder.

Escala gregária: caracterizada no espaço central de Brasília, em torno da intersecção dos Eixos Monumental e Rodoviário e configurado pela Plataforma Rodoviária e pelos Setores de Diversão, Comerciais e Bancários, Hoteleiros, Médico-Hospitalares, de Autarquias e de Rádio e Televisão, Sul e Norte, concebidos para serem locais onde se desenvolvem as atividades cotidianas diárias da população.

Escala bucólica: é a que resulta dos amplos espaços livres contíguos aos terrenos edificados, ou institucionalmente previstos para a edificação, à preservação paisagística e ao lazer, em todas as outras escalas, caracterizando-se pela predominância do verde, pela baixa densidade e pela horizontalidade da paisagem, que confere a Brasília um caráter de cidade-parque. Predomina na orla do Lago Paranoá, nas áreas de cerrado nativo e nos parques urbanos implantados ou previstos, e estão inscritos na área delimitada do conjunto urbanístico do Plano Piloto de Brasília. A escala bucólica geralmente é vinculada ao espaço anti-urbano, desprovido de ocupação é o que normalmente se marca como os grandes vazios de Brasília.

É portanto, por uma rápida exposição, que se busca enfatizar que o discurso que afirma que Brasília é tombada por seguir os preceitos da Carta de Atenas, se equivoca, ao tombar pelo que ela não é, pois seu 'pedigree' diferentemente do que afirma Holston tem antecedentes fortes e marcantes de outros tantos pensamentos.

E ainda, tendo em vista a contradição com alguns preceitos socializantes do CIAM, como, por exemplo, a realização dos subúrbios ${ }^{91}$, de forma cabal, sem as mesmas condições do

\footnotetext{
${ }^{91}$ Aqui podemos citar dois exemplo: Setor de Mansões Suburbanas do Park Way - SMPW, o Setor de Mansões Suburbanos Dom Bosco - SMDB, com lotes de $20.000 \mathrm{~m}^{2}$ e $12.000 \mathrm{~m}^{2}$, respectivamente e que atualmente tem se prestado subdivisão interna criado condomínios de fechados, com parcelas mínimas de $1.500 \mathrm{~m}^{2}$
} 
Plano Piloto original, ou mesmo impondo grandes distâncias entre o espaço da moradia e do trabalho sem os devidos cuidados com transporte público, mas, apenas garantindo a circulação rodoviária.

O tombamento do Plano Piloto deve ser caracterizado pelo que ele é: o esforço estatal na preservação incondicional das escalas estabelecidas pelo preceito do urbanismo de Lúcio Costa, que difere do preconizado por Le Corbusier em vários aspectos morfológicos, e com isso sua filiação acaba por se estender por todo pensamento do urbanismo moderno, pósrevolução industrial, onde podemos ver presentes elementos da cidade-jardim de Howard, da cidade linear de Soria y Mata, e até dos preceitos da Carta de Atenas ${ }^{92}$.

E por isso, como Carpintero busca deixar claro, a concepção de Lúcio Costa é original e representativa da formação do próprio autor, e estabelece um parâmetro de urbanismo brasileiro. Essa é a interpretação a ser usada nesse trabalho, com todas as dificuldades e contradições que tal concepção carrega em si; entendendo que esse empreendimento se realiza num país periférico de economia marcada pelo paradoxo entre o moderno e o atrasado, e que a idéia da construção de nacionalidade, do reconhecimento dos Brasis em um Brasil, são fatores importantes para uma visão social de Brasília.

\footnotetext{
92 Para James Holston, a Carta de Atenas é também resultado das experiências do período e dos pensamentos modernos, tendo várias influências. Mas, esse autor, estabelece que há uma pedagogia intrínseca a Brasília, resultado de uma aceitação, tanto de Lúcio Costa como de Oscar Niemeyer, dos ensinamentos de Le Corbusier. Esse esquema de correlação direta entra em conflito com a própria percepção, e observação da formação intelectual de Lúcio Costa, que como destaca Carpintero, excede aos CIAM, e no caso plástico de Oscar Niemeyer a interferência da estética de Le Corbusier é menor ainda, a não ser que se estabeleça uma leitura exclusiva e direta de Rochamp para todas as edificações de Niemeyer no período. Obviamente há grandes influências, mas as obras dos dois brasileiros se apresentam com muitas outras referências.
} 


\section{CAPÍTULO 2 - A implantação da capital}

Para uma discussão sobre a implantação da capital federal alguns aspectos devem ser levantados.

Primeiro, Brasília não é projeto do movimento modernista, mas sim, uma ação dentro de uma concepção de desenvolvimento nacional, de uma ideologia de nacionaldesenvolvimentismo, que tinha como a principal intenção o aumento do mercado consumidor e um pólo urbano no centro do país se coaduna a esse princípio.

Segundo, como seus pares arquitetos em todo o mundo, os arquitetos e urbanistas brasileiros se associaram à autoridade que aparentemente estava disposta a implementar o programa modernista, o planejamento total, e assim a proposta de mudança social e política a qual os arquitetos se associaram era clara nesse sentido e se implementaria por meio da ampliação das regiões de exploração capitalista, não se pretendia uma revolução portanto.

Terceiro, o objetivo do projeto era construir um lócus de reprodução do Estado brasileiro, um Estado que se pretendia moderno.

A cidade de princípios urbanísticos modernistas é produzida para ser a capital de um país, num momento histórico onde o pensamento hegemônico da economia política brasileira se baseava nas teorias do nacional-desenvolvimentismo capitalista com forte presença do Estado.

O resultado desses aspectos pode ser percebido nas relações entre Estado e sociedade que vão se construindo no decorrer do processo de formação do espaço urbano de Brasília.

Fia-se no entendimento que a formação social brasileira e do Estado moderno brasileiro foram determinantes para a não realização plena da idéia de transformação social pretendida pela implementação do planejamento urbano modernista. Por isso, a decepção do arquiteto e urbanista moderno concretiza dois tipos de críticas: à ineficiência do planejamento total como ferramenta e; ao Estado como agente que não toma este planejamento como vital a transformação social. Esse sujeito com dificuldade reconhece a força das mudanças sociais que operam no conjunto social

Para alguns, o mecanismo do Estado e do planejamento total são agente e instrumento de uma forma de controle social.

Para Gouvêa, no Distrito Federal, 
"os princípios modernistas da Carta de Atenas que direcionaram a configuração física, tanto do Plano Piloto como das Cidades Satélites, convergiram para os interesses das classes dominantes. Brasília serviu, ainda, como objeto de reprodução de ações de controle social desenvolvidas pela FCP (Fundação Casa Popular) e pelo próprio BNH (Banco Nacional de Habitação), por meio da disseminação da ideologia da casa própria. ${ }^{, 93}$

Mas, pode-se marcar uma divergência nessa linha de raciocínio, se temos em vista que independentemente dos mecanismos, o Estado tem que garantir as formas adequadas para a reprodução das relações sociais da sociedade que o legitima. Não é a forma ou preceitos da Carta que determinam o resultado final, nem muito menos as ações de determinados entes administrativos, mas o conjunto do Estado.

Nas ações do Estado em seus Aparelhos, usando a expressão cunhada por Louis Althusser, podem ser observadas as relações necessárias para a reprodução da sociedade brasileira que é desigual. E é nesse sentido e para reafirmar certas situações que o Estado toma para si determinadas partes do ideário modernista da Carta de Atenas e do planejamento total preconizado pelos CIAM para a reprodução das relações necessárias a manutenção dessa sociedade. Dado o discurso que acompanha a ação estatal tem-se a ideologia.

Seja então dos preceitos expressos pelos movimentos modernistas ou de qualquer outra fonte, é da natureza do Estado à apropriação daquilo que the convém para a reprodução das condições necessárias a manutenção da sociedade que o legitima, no caso do Brasil, uma condição onde é legitima a reprodução das desigualdades e a concentração da riqueza. Não é o modernismo a causa dos males ou mesmo a produção de casas pela Fundação Casa Popular e pelo BNH. O sujeito social está inserido no contexto dessa sociedade e é, antes de mais nada, fruto do aprendizado de uma ideologia, de uma transposição não totalizante do real, na qual a aquisição da casa própria se torna condição importante para ser incluído nessa sociedade.

Esse capítulo apresenta as ações do Estado e o contexto em que se inserem para a concretização do espaço urbano da capital. Aborda-se com isso a questão fundiária elemento importante para a constituição do espaço e a implementação das ações para estruturação do aglomerado urbano do Distrito Federal.

${ }^{93}$ GOUVÊA, 1988 p. 34 


\subsection{Questão Fundiária}

Há um mito que se faz a partir de Brasília e sua proposta originária, considerado para este trabalho um aspecto fundamental: A questão fundiária resolvida.

É fato hoje notório a todos os habitantes do Distrito Federal, que as terras têm muito mais donos do que se acreditava, do que o senso comum e do que o discurso competente oficial do Estado afirmava. O porquê da crença e o porquê da descrença, sobre essa compreensão, são pontos de análise desse trabalho.

Ao se iniciar o processo de constituição do Distrito Federal fica determinada, por mensagem do executivo, a desapropriação total das terras inseridas no quadrilátero que iriam formar o novo território do Distrito Federal.

Dentro dessa mensagem, já se estabelecia a quantia de $\mathrm{NCr} \$ 120.000 .000,00^{94}$ para as desapropriações e indenização ao estado de Goiás, as quais se destinavam ao pagamento das glebas que foram adquiridas pelo estado no intuito de agilizar o processo de desapropriação, como já citado no capítulo anterior.

Desse processo, iniciado pelo governo de Goiás a pedido do então presidente da Comissão de Localização e Mudança da Nova Capital, Marechal José Pessoa, resulta a primeira grande pesquisa e identificação da estrutura fundiária primitiva do território da Nova Capital, no qual foram mapeadas todas as fazendas e respectivas glebas contidas no quadrilátero, fato que, segundo o engenheiro responsável pela medição Joffre Parada, não ocorria desde a instituição do regime de Registro Paroquial, sendo que o último levantamento de propriedades da região havia ocorrido entre 1855 e 1858, ou seja, exatos 100 anos separam esses dois levantamentos.

O resultado desse trabalho é o que se denominou de Cadastro dos Imóveis Rurais Primitivos do Novo Distrito Federal, no qual constava uma documentação jurídica com o histórico atualizado desde o Registro Paroquial, ou, desde a origem particular das terras. Relação nominal de todas as fazendas com suas respectivas áreas e limites.

O Cadastro é parte dos trabalhos da Comissão de Cooperação para Mudança da Nova Capital a qual realiza as primeiras desapropriações de terras, sendo que, muitas foram as glebas que efetivamente cumpriram o rito de desapropriação, chegando assim a se configurar como patrimônio público, sejam hoje da União ou do Distrito Federal. Entretanto,

\footnotetext{
${ }^{94}$ A valores corrigidos pelo INCC-FGV, trazidos a 31 de dezembro de 2007, seriam $\mathrm{R} \$$
} 
apesar de todo esse trabalho realizado, o processo que se deu, necessitou de inúmeras maneiras distintas de proceder à transferência.

Em alguns casos observou-se a transferência direta, em outros foram necessários instrumentos alternativos que limitavam a comercialização da gleba particular, como compromissos de compra e venda, e categorias legais como desapropriação em comum, na qual o imóvel torna-se um co-domínio entre particular e poder público com percentuais préestabelecidos sem glebas definidas dentro da propriedade, sem ação discriminatória.

Essa última e diferente forma de reserva fundiária visava restringir a comercialização das terras dentro do Distrito Federal, para que posteriormente o governo pudesse, adquirir essas glebas em reserva particular, para compor seu estoque de terras.

A verdade é que muitas dessas glebas jamais foram adquiridas integralmente pelo governo e soma-se a essa situação a própria dificuldade em unificar os cadastros dos cartórios da região, nos quais era observada a duplicidade de matrículas e registros em comarcas distintas, ou seja, a mesma gleba era registrada em mais de uma paróquia, ou cartório. Entre outras dificuldades existia também a determinação dos tamanhos reais das glebas e da qualidade legal do registro de transferência.

Essa situação anômala, descrita a seguir, obviamente dificultou os trabalhos da Comissão de Cooperação, a qual foi, durante os anos de 1955 a 1958, a maior responsável ${ }^{95}$ por compras de terras de particulares na região.

O fato é que se criou um mito do controle fundiário total, derivado do monopólio da propriedade fundiária estatal, o que nunca existiu. Contudo não é possível desconsiderar o poder por trás da idéia. Brasília, até que se prove em contrário, por meio de um decreto de desapropriação, reafirmou seu controle fundiário, usando como mecanismo a impossibilidade legal de parcelamento de terras particulares no Distrito federal, situação que se prolongou até 1992, com a decretação do Plano Diretor de Ordenamento Territorial que facultou ao proprietário privado de terras o direito de parcelamento para fins de loteamento urbano e rural.

\footnotetext{
${ }^{95}$ Pelos levantamentos documentais realizados para essa pesquisa, não foi possível identificar ação da NOVACAP. Mesmo assim, optou-se por entender que por não encontrar registro, não significa necessariamente, que não houve ação, já que é senso comum reproduzido constantemente que a companhia atuou desde o começo nas desapropriações.
} 
MAPA II Mapa da situação fundiária do Distrito Federal, com os limites das antigas fazendas mapeadas pelo Cadastro Rural de Imóveis Primitivos do Novo Distrito Federal e com os antigos limites municipais

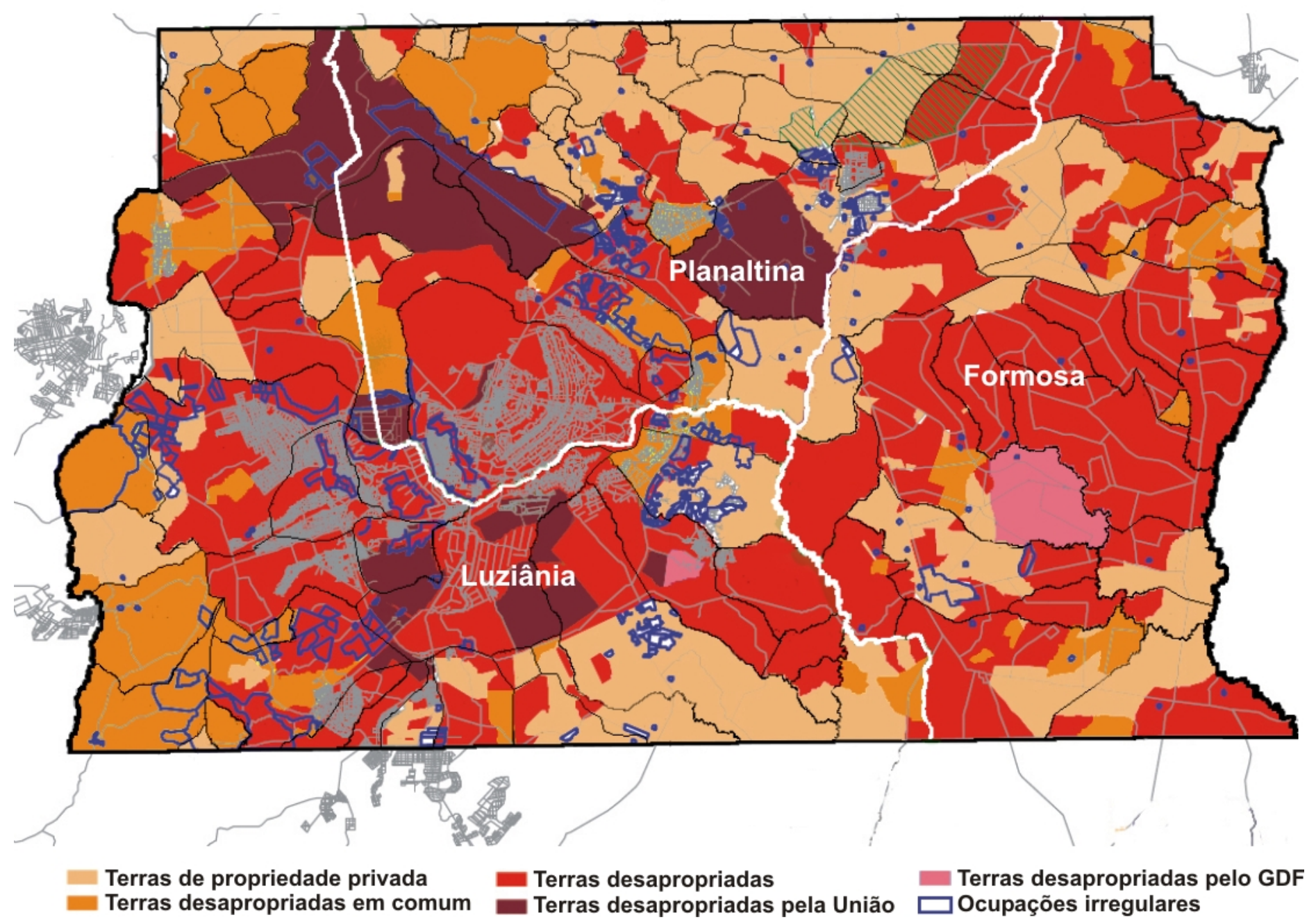

Fontes: Secretaria de Estado de Desenvolvimento Urbano e Habitação (SEDUH) - Governo do Distrito Federal - 2007. Patrimônio Geral da União - PGU/ 2006 
Mas essa "abertura" legal chega tarde. Segundo a Secretaria de Estado de Desenvolvimento Urbano e Meio Ambiente do Distrito Federal ${ }^{96}$ (2007), em 1975 já havia sido identificado o primeiro parcelamento de condomínio irregular no Distrito Federal, chegando à quantidade de 529 parcelamentos no ano da decretação do PDOT-1992.

Sobre os mecanismos de controle e fiscalização ao parcelamento desconforme, irregular, que sempre houve, podemos citar o Sistema Integrado de Vigilância do Uso do Solo - SIV-SOLO ${ }^{97}$, uma espécie de polícia fundiária que tinha por objetivo policiar as ocupações.

Atuante, mas sem condições reais de lidar com processos mais pulverizados e que envolvam ações de negociação, se tornou na década de 80 , pouco eficiente, principalmente quando as terras ocupadas apresentavam algum tipo de litígio, ou mesmo, em situações que se observava maior articulação comunitária e política que garantisse a manutenção da posse ao ocupante. Contudo, sua ação de controle quanto às ocupações feitas por população de baixa renda sempre foram mais efetivas do que quando os envolvidos eram identificados como componentes da classe média ou alta, como afirma Maria da Conceição Gonçalves ${ }^{98}$.

O SIV-SOLO está realmente na categoria althusseriana de Aparelho de Repressão do Estado ${ }^{99}$, e por isso sua ação é sempre mais efetiva nas ações de coibição e uso da violência legitimada para a garantia da reprodução das relações da sociedade.

Se observada também a complexidade criada com as formas descritas de desapropriação criadas pelo Estado em sua ação de definição do perímetro físico de sua sede, fica clara a dificuldade de qualquer instituição, ou organismo do Estado em dar conta da situação de forma isolada.

Um questionamento vem à tona: seria possível estabelecer uma relação entre questão de propriedade fundiária de terras que constituem o território do Distrito com o processo de evolução urbana? A princípio parece uma questão primariamente óbvia, se não houvesse um quadro atual de aglomerados urbanos, resultado de empreendimentos estatais em terras de

\footnotetext{
${ }^{96}$ SEDUMA

${ }^{97}$ Criado em 1993

${ }^{98}$ GONÇALVES, Maria da Conceição Vasconcelos. Favelas Teimosas. Brasília: Thesaurus, 1998

${ }^{99}$ ALTHUSSER, Louis - Aparelhos Ideológicos de Estado
} 
propriedade privada ${ }^{100}$, não desapropriadas portanto. Então qual a influência da propriedade fundiária na matriz de ocupação e planejamento urbano estatal do Distrito Federal?

\subsubsection{Aquisição de terras e o mito da terra pública}

Dados da Companhia Imobiliária de Brasília - TERRACAP divulgados pela Secretaria de Estado de Desenvolvimento Urbano e Meio Ambiente, dão conta de que 51,36\% das terras do Distrito Federal foram integralmente desapropriadas, estando sob o domínio do Distrito Federal ou da União ${ }^{101}, 8,53 \%$ estão desapropriadas em comum, 6,83\% em processo de desapropriação, e um percentual representativo de $33,28 \%$ das terras são de propriedade privada.

Para se ter uma dimensão do estoque estatal, mais de $3.000 \mathrm{~km}^{2}$, duas vezes o território do município de São Paulo, são terras que foram efetivamente desapropriadas pelo Estado. Uma quantidade considerável do território do DF é propriedade estatal, mesmo consideradas as áreas já repassadas ao domínio particular por alienação, resultado de processos licitatórios, pouco modificam esse volume.

Sob uma ótica inversa da apresentada, um terço das terras são de propriedade privada, não contestadas pela TERRACAP. Contudo isso não representa que todas as terras das quais a companhia declara de sua propriedade são absolutamente entendidas assim, já que existem contestações judiciais movidas por particulares.

Por esse viés, nem tudo que é declarado de propriedade estatal assim o é, e a existência de documentos de propriedade, título de propriedade, e as contestações judiciais relativas a procedimentos não conclusos de desapropriações ajudam a corroborar essa ótica.

Cecília Juno Malagutti ao estudar a questão dos loteamentos, em sua dissertação, Loteamentos Clandestinos no DF: Legalização ou Exclusão, em 1996, busca estabelecer o cenário das

\footnotetext{
${ }^{100}$ A cidade-satélite do Paranoá é um exemplo dessa situação, com uma população de 54.902 habitantes em 2000 (CODEPLAN) está inserida em área de propriedade privada. Outro exemplo é a cidade-satélite de Santa Maria, onde mais de 300 lotes localizados em terras não desapropriadas até 1998. Como se vê os exemplos são muito mais recorrentes.

${ }^{101}$ Entre as terras contabilizadas pela União encontram-se terras devolutas.
} 
contestações.

Em primeiro lugar é importante observar que nem todos os registros cartoriais que se apresentavam eram, ou são, considerados bons, para efeito de comprovação de propriedade.

"Segundo registros da comissão encarregada pelas desapropriações, várias propriedades não puderam ter concluídos os seus processos de desapropriação em razão da precariedade dos títulos de domínio exibidos pelos seus ocupantes. "102

Apesar de não estar claro a qual comissão se refere, se a Comissão de Cooperação para Mudança da Nova Capital, do estado de Goiás, ou a Comissão de Planejamento de Construção e Mudança da Capital Federal, do governo federal, o fato é que a ação de desapropriação, o ato expropriatório, encontra dificuldades quanto à validade documental apresentada pelos ocupantes, o que pode ser considerado como uma decorrência das formas de registro e cadeias dominiais, até mesmo de origem da forma instituída ao estatuto da propriedade privada no Brasil feito pela lei de Terras de 1850.

Além da dificuldade na análise, na avaliação dos documentos e títulos, desde o início dos trabalhos de negociação com os proprietários e ocupantes, até o registro e transferência dos títulos, a partir de 1965, o processo ganha novo agente e novo elemento. A Vara da Fazenda Pública começa a negar ao Distrito Federal, representado pela NOVACAP, o direito de desapropriação das terras ${ }^{103}$.

Para espanto, como coloca Malagutti, "a Justiça alegava falta de legitimidade da causa, pois não podia desapropriar uma área que já era da União desde a Constituição de 1891, e a ação de desapropriação era rejeitada liminarmente"104.

O ato de desapropriação do Distrito Federal, parecia à época tão resolvido e ao mesmo tempo

\footnotetext{
102 MALAGUTTI, Cecília Juno - Loteamentos Clandestinos no DF: Legalização ou Exclusão? Dissertação de Mestrado - FAU UnB 1996, p. 29

${ }^{103}$ No Anexo cópias de despachos de um processo para desapropriação de área requerida pela NOVACAP, acervo do Arquivo Público do Distrito Federal (ArPDF) - Fundo NOVACAP, no qual é reproduzida parte da história e posterior argumentação do procurador da companhia buscando a conclusão do processo em 1966.

${ }^{104}$ MALAGUTTI, 1996, p. 21
} 
tão confuso, que leva a interpretações administrativas e jurídicas que asseguravam a aparente ação paradoxal do Estado. Requerer a desapropriação de terras para legitimar sua ocupação e negá-la não ter legitimidade o pedido.

Em 1967, por solicitação do Juiz de Registros Públicos à Corregedoria do Tribunal de Justiça do DF, é baixado um Provimento proibindo os registros de imóveis na DF, de forma a não interferir nas desapropriações efetuadas pelo governo do DF, além do decreto "N" n 636, de 26 de julho de 1967, que regulamentava a desapropriação de terras do Distrito Federal. Num intuito de congelar qualquer que fosse o processo de transferência de propriedade fundiária até a solução legal.

Essa proibição legal estabelecida em decreto perdura até 1975, quando é liberado o registro para três casos específicos: para proprietários cujas posses possuíssem registro paroquial; para aqueles que já tivessem sentença julgada de usucapião até 1 de janeiro de 1917; ou, ainda, para as doações feitas pela União depois da promulgação da Constituição de 1891.

Nesse mesmo ano é identificado o primeiro condomínio "informal", o Country Club Quintas da Alvorada, hoje conhecido como Quintas da Alvorada.

Para se ter mais alguns elementos para análise, mais como registro para o entendimento da questão fundiária que ganha contornos próprios, em 1995, a Câmara Legislativa do Distrito Federal criou a Comissão Parlamentar de Inquérito - CPI da Grilagem que em seu relatório final declara:

“"(...) Daí não ser impróprio falar que a problemática fundiária do Distrito Federal começa exatamente na indefinição dos limites dessas terras particulares que não puderam ser alcançadas pelos atos expropriatórios, com os das terras públicas, problemática essa causada pela sanha devastadora de gananciosos empresários e inescrupulosos grileiros, que deslocavam os titulos dessas áreas particulares, quase sempre adquiridas mediante processos fraudulentos, para terras públicas, legalmente desapropriadas, só que bem mais valorizadas do que as quais dizem possuir o domínio" (CA apud Malagutti) ${ }^{105}$

Pode-se afirmar que o parcelamento do solo por particulares acompanhou o processo de formação do Distrito Federal desde o início do processo de implantação. Nos primórdios da cidade, o parcelamento de terras por particulares era uma constante preocupação que causava

${ }^{105}$ MALAGUTTI, p. 21 
toda uma série de problemas. Encontram-se referências dessa prática nos relatos de Altamiro Pacheco, presidente da Comissão de Cooperação para a Mudança da Nova Capital:

"Divulgando-se, através da imprensa e do rádio, a notícia de se haver criado a Comissão de Cooperação para a Mudança da Capital Federal, com a incumbência de adquirir as terras do Novo Distrito Federal, recebemos, tão logo assumimos a sua presidência, telegramas, ofícios e cartas dos mais variados pontos do País.

Os signatários, elementos de todas as classes sociais e portadores de títulos expedidos pela Prefeitura de Planaltina relativamente a lotes naquele município, pediam-nos que os esclarecêssemos sobre a situação jurídica dos aludidos documentos ou indagavam da localização e valor dos respectivos lotes.

(...) À medida que o tempo decorria e o trabalho se adiantava, intensificava-se, pelo lado dos possuidores de semelhantes escrituras, o interesse em legalizá-las. Eram documentos, há muito, desprezados e, na sua grande maioria, não registrados, mas denunciadores de algo que se esboçava....

Examinando-se, então, o assunto, com a atenção e carinho reclamados pela importância do problema que surgia, verificamos ser bastante elevado o número de loteamentos, na área demarcada para o Novo Distrito Federal. "106

Já em 1956, 10 anos antes do indicado por Malagutti, Altamiro Pacheco marca a ação de empreendedores particulares promovendo o loteamento e comercialização dessas glebas, citando os seguintes:

- Planaltinópolis - nas fazendas Monjolo, Bom Sucesso, e Lambari;

- Platinópolis - na fazenda Pipiripau (fonte: ArPDF - desde 1927 - concessões expedidas pela municipalidade de Planaltina)

- Chácaras Santa Maria - na fazenda Lambari

- Planópolis - na fazenda Bananal (fonte: ArPDF - desde 1927)

- Vila Federal - na fazenda Bom Sucesso

- Sociedade Anônima, Planalto Central de Goiás - na fazenda Sálvia

- Nossa Senhora de Fátima - na Fazenda Mestre d'Armas

Pacheco denunciava essa situação em seus relatórios, pois entendia como uma ação anti-

${ }^{106}$ PACHECO, Altamiro M. Primórdios de Brasília p. 85 
pratriótica a prática da contínua comercialização de lotes no território do novo Distrito Federal, que acabava por criar dificuldades enormes à desapropriação dos imóveis. Valia-se para responder as consultas do público interessado na aquisição desses imóveis, ou, mesmo àqueles que se diziam proprietários de lotes, das determinações do decreto do governo goiano posteriormente referendado pela União, como instrumento legal que coibia as negociações de compra, venda e parcelamento do solo do novo Distrito Federal.

Segundo Lucídio Guimarães Albuquerque ${ }^{107}$, alguns desses parcelamentos irregulares ocorreram logo após a colocação da Pedra Fundamental da Nova Capital em 7 de setembro de 1922 na cidade de Planaltina ${ }^{108}$. Ainda dá pistas sobre uma ação especulativa induzida pela ação do poder público local, afirmando que parte desses loteamentos foram suscitados por prefeitos locais. ${ }^{109}$

O mito do processo sumário da desapropriação e a totalidade do domínio das terras como públicas, tem sua conotação ideológica, uma vez que, o discurso que se cria visa à preservação e contenção de um processo da dinâmica imobiliária privada.

A reserva de boa parte do território do quadrilátero, durante esses mais de 50 anos, tem relação direta com esse discurso ideologicamente construído, que tem sua exposição à realidade, na proliferação das ocupações das terras privadas do Distrito Federal.

Mesmo que partes do discurso fossem sendo desfeitas no decorrer dos anos pela mera observação dos fatos como a não conclusão de contratos de compra direta entre Estado e particulares registrados por compromissos de compra e venda, processos judiciais de desapropriação não concluídos e desistência do interesse público em alguns casos, a imagem que se criou de um contínuo processo de desapropriação e a restrição ao loteamento privado, não destituíram o poder da proposta original que era a contenção da especulação imobiliária. É estabelecido um controle alternativo pela proibição, já que a eliminação da ação do mercado imobiliário é absolutamente impossível no sistema econômico ao qual o Brasil é integrante.

\footnotetext{
${ }^{107}$ ALBUQUERQUE, Lucídio Guimarães.

${ }^{108}$ O lançamento da Pedra Fundamental fez parte da comemoração do centenário da Independência.

${ }^{109}$ Parecer da NOVACAP sobre estes parcelamentos foram encontrados no Arquivo Público do Distrito Federal e encontra-se no anexo,
} 
Até mesmo a complexidade que se criou no âmbito da situação fundiária, contribui para esse discurso, que atribui o aparente descontrole e caos a não observação da desapropriação, que como vimos, chegou a ser considerada concretizada desde 1891 por ato constitucional.

No fundo da questão está a natureza da propriedade privada, como já destacado, e quem a possui ou a registra como sua por título público. A unificação de documentos dos direitos de posse e domínio, concomitante, estabelece um ponto importante na história da propriedade no Brasil. Os Registros Paroquiais eram uma forma precária e, hoje, observasse que houve um número considerável de duplicidade nesses registros.

É imprescindível observar que aparentemente ${ }^{110}$ a ação de aquisição pela NOVACAP ocorre de forma posterior ao processo iniciado pelo estado de Goiás veja quadro:

TABELA I. Quantidade de áreas desapropriadas pela NOVACAP com escritura pública definitiva com respectivos valores e percentual, no período de 1960 a 1965, e incidências no percentual geral de terras adquiridas até 1965 , consideradas as desapropriações feitas pela Comissão de Cooperação goiana (1955-58).

\begin{tabular}{|c|c|c|c|c|}
\hline Ano & $\begin{array}{l}\text { Área (Alqueires } \\
\text { Geométricos)" }\end{array}$ & $\begin{array}{l}\text { Valores pagos }{ }^{2} \\
(\mathrm{R} \$)\end{array}$ & $\begin{array}{l}\text { Percentual } \\
\text { NOVACAP }\end{array}$ & $\begin{array}{l}\text { Percentual } \\
\text { geral }^{3}\end{array}$ \\
\hline 1960 & $16.919,515$ & $12.234 .073,35$ & $89,92 \%$ & $34,04 \%$ \\
\hline 1961 & 0,000 & 0,00 & $0,00 \%$ & $0,00 \%$ \\
\hline 1962 & 458,225 & $137.368,58$ & $2,43 \%$ & $0,92 \%$ \\
\hline 1963 & $1.067,816$ & $25.102,89$ & $5,67 \%$ & $2,15 \%$ \\
\hline 1964 & 162,894 & $43.172,83$ & $0,87 \%$ & $0,33 \%$ \\
\hline 1965 & 208,000 & $79.523,57$ & $1,11 \%$ & $0,42 \%$ \\
\hline Total & $18.816,450$ & $12.519 .241,22$ & $100,00 \%$ & $37,86 \%$ \\
\hline
\end{tabular}

Fontes: Arquivo Público do Distrito Federal - ArPDF/ Fundo NOVACAP anos de 1957 a 1970.

Notas: ${ }^{1} \mathrm{O}$ alqueire geométrico corresponde a 4,84 hectares $(220 \mathrm{~m} \times 220 \mathrm{~m})$.

${ }^{2}$ Os valores expressos estão reajustados a 31/12/2007 pelo INCC-FGV

${ }^{3}$ Em relatório da Comissão de Cooperação para Mudança da Nova Capital por ela foram negociados nada menos que 39.843,637 alqueires geométricos, sendo que destes 30.886,373 alqueires geométrico já com transferência de Escritura Pública a favor do governo de Goiás e o restante com Escritura Pública de Compromisso de Compra e venda .

${ }^{110}$ Ver nota de rodapé 95 
A interrupção do processo, a diminuição na velocidade e outras tantas situações decorrentes da dinâmica de formação e evolução urbana, provocaram um imbróglio quanto à posse da terra. Tanto Tavares como Albuquerque enumeram de 22 a 25 tipos de situações de posse e uso da terra. Cita-se:

1. Terras de propriedade do Distrito Federal;

2. Terras de propriedade da União;

3. Terras devolutas;

4. Terras de propriedade do Distrito Federal e de terceiros, em regime de propriedade comum;

5. Terras de propriedade da União e de terceiros, em regime de propriedade comum;

6. Terras de propriedade do Distrito Federal, parceladas e arrendadas pela Fundação Zoobotânica do Distrito Federal;

7. Terras de propriedade da União, parceladas e arrendadas pela Fundação Zoobotânica do Distrito Federal;

8. Terras não desapropriadas pelo poder público, tituladas pelo INCRA no Projeto Integrado de Colonização Alexandre Gusmão - PICAG;

9. Terras desapropriadas pela União, tituladas pelo INCRA no Projeto Integrado de Colonização Alexandre Gusmão - PICAG;

10. Terras não desapropriadas pelo poder público, parceladas e arrendadas pela Fundação Zoobotânica do Distrito Federal

11. Terras desapropriadas pelo Distrito Federal, em poder de posseiros;

12. Terras desapropriadas pela União, em poder de posseiros;

13. Terras de propriedade do Distrito Federal e/ou da União transformadas em Áreas Isoladas, arrendadas pela Fundação Zoobotânica;

14. Terras de propriedade do Distrito Federal, da União e de particulares que integram parques, reservas biológicas, santuários ecológicos;

15. Terras de propriedade do Distrito Federal, da União e/ou de particulares destinada à captação de água para abastecimento púbico;

16. Terras desapropriadas, ainda ocupadas pelos antigos proprietários e/ou seus herdeiros;

17. Terras consideradas de utilidade pública, para fins de desapropriação e ocupadas pelo poder expropriante;

18. Terras desapropriadas, ainda em demanda judicial por iniciativa dos 
desapropriados ou do poder expropriante;

19. Terras de propriedade particular ocupadas pelos seus proprietários;

20. Terras de propriedade particular ocupadas por posseiros

21. Terras de propriedade pública parcelada, loteada e vendida por particulares;

22. Terras de propriedade particular loteadas clandestinamente;

23. Invasões rurais em cascalheiras, argileiras, cerâmicas, e áreas de mananciais;

24. Terras de propriedade particular ocupadas pelo poder público;

25. Terras com ações movidas pela União;

\subsubsection{Comissão de Cooperação para a Mudança da Nova Capital}

"O nosso trabalho foi o de conhecer a matéria-prima, a argila bruta, que servirão de base territorial ao mármore de Brasília.

Esse grande mosaico sobre o qual, durante longo tempo, pousou angustiada a nossa vista, sequiosa de esclarecimentos, e que é o novo Distrito Federal, na parte a nós entregue, constitui a princípio o mistério, o silêncio que se opõe ao estudioso que interroga o tempo, os papéis, os livros, os processos e a memória dos coevos, em busca da resposta: a quem pertenceu tudo isso; como circularam na rodem do tempo as frações dessa imensa área; que ficou por fazer; a quem pertence, hoje, enfim, tudo isso?"111

A Comissão de Cooperação para a Mudança da Nova Capital criada em outubro de 1955 é um marco fundamental para o entendimento da questão fundiária no Distrito Federal, sua ação possibilitou que, em 1955, fosse iniciado o processo de transferência da Nova Capital.

Presidida pelo médico e fazendeiro da região, Altamiro de Moura Pacheco, esta comissão atuou entre 1955 e 1958 nomeada pelo governador do estado de Goiás, José Ludovico de Almeida pelo decreto $n .^{\circ} 1.258$ e empossada em 8 de outubro de 1955.

Coube ao governo de Goiás a iniciativa de declarar a área do quadrilátero escolhida, indicada no relatório final da Comissão de Estudos para Localização da Nova Capital, como de utilidade pública, devido à recusa do Presidente da República, então em exercício, Café Filho.

Essa situação aparentemente estranha de uma unidade da federação promover a

${ }^{111}$ PACHECO, Altamiro de Moura, 1978. pg 56 
desapropriação e, não a União, teve como protagonista o presidente da Comissão de Localização, Marechal José Pessoa, que, diante da recusa do então Presidente da República em iniciar o processo, recorre ao governador de Goiás com os auspícios do então candidato eleito Juscelino Kubitschek de Oliveira. Ou seja, é no interregno de fim de mandato presidencial de Café Filho, no meio a intensa discussão mudancista que o fato está inserido.

É então a partir do decreto estadual 480, de 30 de abril de 1955, que declara as terras do quadrilátero $^{112}$ de utilidade pública, ratificado pela Lei Federal $n^{\circ} 2874,18$ de setembro de 1956 e o decreto de criação da Comissão Cooperação para Mudança da Nova Capital que tem início o processo de mudança. E em dezembro de 1955, ocorre a primeira desapropriação, antes então do início do mandato de JK.

A desapropriação da primeira gleba ocorreu de forma amigável, e é onde está inserido o Plano Piloto. A Fazenda Bananal foi onde se marcou o lugar da futura capital, onde se tomou posse do espaço, nas palavras de Lúcio Costa. (Anexo)

Segundo Darcy Dornelas de Farias, em sua dissertação de mestrado, Terras no Distrito Federal - experiências com desapropriação em Goiás, o processo de desapropriação ocorria por duas frentes, uma pela Comissão de Cooperação para a Mudança da Nova Capital vinculada ao estado de Goiás e a outra pela Comissão de Mudança da Nova Capital.

O resultado material desse trabalho de desapropriação, que são as glebas tornadas de propriedade estatal, representam algo em torno de $50 \%$ de todas as terras públicas da atual estrutura fundiária do Distrito Federal, sendo ainda que, mais de $44 \%$ do total das terras adquiridas pela NOVACAP no período de 1960 a 1965 já haviam sido negociadas por essa comissão. Portanto, o trabalho da comissão goiana representou a negociação e compra por ela e pela NOVACAP de nada menos que um terço do território do Distrito Federal.

Para se compreender a complexidade e dificuldade da ação de desapropriação do Distrito Federal, cabe lembrar que num aspecto territorial e administrativo, até político, o quadrilátero federal se compôs com o desmembramento de terras de três municípios goianos: Luziânia, Formosa e Planaltina.

Segundo Farias, a escolha do presidente da Comissão de Cooperação era muito importante e se caracterizava como uma estratégia para agilizar os procedimentos e acordos amigáveis, já

${ }^{112}$ Esta área é a mesma estudada no Relatório Belcher de 1948. 
que se tinha a pretensão de desapropriar todas as glebas que compunham as fazendas mapeadas, por meio de negociações extrajudiciais, ou seja, de forma amigável.

Altamiro de Moura Pacheco era médico e grande proprietário de terras na região, vinculado a vários grupos e associações, sendo muito respeitado e com um histórico político apartidário, que o qualificava como um bom mediador das ações. Portanto, era um nome considerado indicado, seu transito em meio aos proprietários visava auxiliar os trabalhos da comissão, segundo depoimentos colhidos por Farias.

A intensificação do processo de construção da capital federal, segundo essa autora, motivou o processo de especulação imobiliária, como pode ser identificado no relatório do advogado Eduardo Henrique de Souza Filho, membro da comissão de cooperação, enviado a Altamiro Pacheco ${ }^{113}$. O advogado alegava que as negociações de compra direta, ou as desapropriações amigáveis, como identificavam, já encontravam seu limite, apontando para a necessidade de partir para processos judiciais.

Com o decorrer das obras e da ocupação do Distrito Federal pré-inauguração, os processos amigáveis estavam encontrando dificuldades em seus andamentos, com contestações quanto a valores e dificuldade quanto à verificação da legitimidade de títulos apresentados por ocupantes que, em alguns casos, não se caracterizavam como confiáveis.

Os relatórios da Comissão de Cooperação dão conta de vários procedimentos no intuito de agilizar e realizar a operação de aquisição das terras. De início, um único escritório centralizava os trabalhos, mas tendo visto a complexidade dos trabalhos, tornou-se necessária a criação de três escritórios volantes um em cada município com um responsável, chegando até a dispor de um pequeno avião monomotor cessna, para o trânsito entre municípios.

Outro ponto sempre negociado e que era geralmente usado como moeda de troca para agilizar a aquisição do imóvel se constituía em um compromisso futuro no qual a NOVACAP arrendaria terras dentro do novo Distrito Federal para a continuidade da produção rural, e, capitalizado com a desapropriação, o produtor poderia reinvestir na sua atividade.

Os trabalhos tinham sua base jurídica apenas no Decreto estadual 480, de 30 de abril de 1955, que declara as terras de utilidade pública, que posteriormente é ratificado pela Lei Federal $n^{\circ}$

\footnotetext{
${ }^{113}$ Vários relatos e depoimentos estão na publicação de PACHECO, Altamiro de Moura. Primórdios de Brasília.
} 
2874, de setembro de 1956, e o Decreto-Lei 3365, de 21 de junho de 1941 que doutrinavam sobre as normas de desapropriação.

Num prazo de pouco mais que três anos, tendo vista, a rápida alteração do cenário da região com as obras da nova capital, o tempo de trâmite das transferências de registros, os trabalhos de mensuração de campo e verificação das glebas, as pesquisas nos cartórios, entre tantas outras ações, a comissão conclui seus trabalhos tendo, segundo seu presidente, adquirido um terço do território do quadrilátero, 39.843,637 alqueires geométricos, aproximadamente 1.928 $\mathrm{km}^{2}$.

TABELA II. Quantidade de áreas desapropriadas pela Comissão de Cooperação para Mudança da Nova Capital, com escritura pública com respectivos valores e percentual, no período de 1955 a 1958, e incidências no percentual geral de terras adquiridas até 1965, consideradas as desapropriações da NOVACAP (1960-65).

\begin{tabular}{lllll}
\hline Ano & $\begin{array}{l}\text { Área (Alqueires } \\
\text { Geométricos) }\end{array}$ & $\begin{array}{l}\text { Valores pagos } \\
(\mathrm{R} \$)\end{array}$ & $\begin{array}{l}\text { Percentual } \\
\text { CCMNC }\end{array}$ & $\begin{array}{l}\text { Percentual } \\
\text { geral }^{3}\end{array}$ \\
\hline 1955 & $4.750,000$ & - & $11,92 \%$ & $9,56 \%$ \\
1956 & $17.941,754$ & - & $65,72 \%$ & $36,10 \%$ \\
1957 & 332,000 & - & $3,32 \%$ & $0,67 \%$ \\
1958 & $7.862,619$ & - & $19,04 \%$ & $15,81 \%$ \\
\hline Total & $30.886,373$ & $3.883 .776,23$ & $100,00 \%$ & $62,14 \%$ \\
\hline
\end{tabular}

Fontes: PACHECO, Altamiro de Moura. Primórdios de Brasília. Goiânia: Líder, 1978.

Notas: ${ }^{1}$ Os alqueires geométricos correspondentes a 4,84 hectares $(220 \mathrm{~m} \times 220 \mathrm{~m})$. Em relatório da Comissão de Cooperação para Mudança da Nova Capital - CCMNC, por ela foram negociados nada menos que 39.843,637 alqueires geométricos, sendo que destes 30.886,373 alqueires geométrico com transferência de Escritura Pública a favor do governo de Goiás e o restante com Escritura Pública de Compromisso de Compra e venda.

${ }^{2}$ Os valores expressos estão reajustados a 31/12/2007 pelo INCC-FGV. Existe apenas uma contabilidade geral que pôde ser disponibilizada para a pesquisa, presente em documento de transferência (Cr\$ 18.255.789,50 em 18 de maio de 1957)

${ }^{3}$ Somados os 30.886,373 alqueires geométrico com transferência de Escritura Pública a favor do governo de Goiás e o restante com Escritura Pública de Compromisso de Compra e venda .

A bem da verdade, nem todas as escrituras públicas da comissão se referiam a escritura pública de transferência de propriedade, como descrito anteriormente, um parte se caraterizou como escritura pública de compromisso de compra e venda. Se colocados em perspectiva, os trabalhos da Comissão de Cooperação para Mudança da Nova Capital, podem ser 
considerados notáveis quanto à velocidade e ao resultado. Mas, como inconcluso ficou, se torna difícil saber qual seria o cenário se a mesma continuasse na ação de aquisição de terras até a constituição administrativa do Distrito Federal, mesmo tendo em vista algumas estratégias usadas como: dar prioridade as ações de desapropriação nas fazendas constituídas de chapadas ou campos, com baixa percentagem de matos ${ }^{114}$, que representava segundo Pacheco, 90\% do território do Novo Distrito Federal, e; Iniciar pelo centro do quadrilátero indo para a periferia do território, tendo em vista que existia uma dificuldade em estabelecer com precisão os paralelos Norte e sul do território.

Existiam ainda, terras de dois outros tipos: pequenas fazendas, com benfeitorias melhores, mais valorizadas e maior produtividade; e fazendas muito valorizadas com grande quantidade de pasto, já que a pecuária era uma das atividades mais tradicionais e rentáveis da região.

Segundo Farias eram várias as maneiras com que a Comissão de Cooperação, em especial o presidente, abordavam o proprietário, desde o oferecimento de futuras terras a serem arrendadas dentro do DF para a produção agrícola até o aconselhamento de investimento em terras no entorno do quadrilátero como maneira de ganhos futuros, ou mesmo acordos para ocupação de terras devolutas em Goiás ${ }^{115}$.

Assim, mesmo com todas essas formas descritas de atuação, é impossivel criar um cenário de análise no qual seja incluído o prolongamento dos trabalhos da Comissão de Cooperação. Entretanto, na leitura de Farias, o embate existente entre as comissões e grupos de interesses foi marcante ${ }^{116}$, ficando a impressão de que apesar da importância da aquisição de terras, essa

\footnotetext{
${ }^{114}$ Matos aqui referem-se a pasto, e não a matas que devem ser preservadas, respeitando o estatuto forestal.

${ }^{115}$ Chegou a ser publicado decreto-lei que outorgava ao poder público a dação em pagamento pela desapropriação, terras devolutas em outras regiões. Não foi encontrado nenhum registro de que tenha ocorrido algum tipo de negociação com essas características, entende-se a dificuldade de tal ação pois necessitaria uma ação discriminatória em diversas regiões.

116 Farias manifesta uma disputa entre Altamiro Pacheco, presidente da Comissão de Cooperação (goiana) e Ernesto Silva, presidente da Comissão de Planejamento e Mudança (federal) e posteriormente diretor da NOVACAP, com também uma relação tempestuosa entre Israel Pinheiro, presidente da NOVACAP e Jeronymo Bueno então senador por Goiás e um dos principais defensores e articuladores da mudança da capital para Goiás.
} 
não era a única ação com prioridade em todos os momentos da estruturação do território do Distrito Federal, já que é expressivo o estoque rapidamente estabelecido pela Comissão de Cooperação e NOVACAP até dezembro de 1960, cerca de 47.800 de alqueires geométricos. O volume de aquisições cai exponencialmente até 1965, quando são computados quase 49.700 alqueires geométricos, ou $2.400 \mathrm{~km}^{2}(41,46 \%$ do território do DF).

Após 1965 as ações tocadas pela NOVACAP, posteriormente pela TERRACAP e governo federal, durante os 40 anos seguintes acrescentaram a esse estoque algo entorno de $10 \%$ do território total.

Obviamente alguns fatores contribuíram para que esse processo tivesse seu ritmo refreado em 1961 com a criação da CPI que investigou as contas das empresas e órgãos públicos que financiaram a implantação de Brasília, observa-se a suspensão das operações de compra, que retornam em 1962 e novamente sendo paralisadas a partir de 1965 devido a pareceres jurídicos já citados. Nesse panorama nenhuma das Comissões teria êxito a não ser se entre 1958 e 1960, houvesse ocorrido uma massiva compra de terrenos no auge da construção acelerada.

Mesmo com disponibilidade de recursos para tal ação, dada a verba inicial de $\mathrm{NCr} \$$ $120.000 .000,00^{117}$, há também outros fatores que fogem a essa análise, tais como:

- Após a instalação e instituição da NOVACAP, a Divisão de Terras do Departamento de Terras e Agricultura era responsável pela aquisição de terras. Sob a direção de Joaquim Alfredo da Silva Tavares respondia diretamente a Íris Meinberg, um dos quatro Diretores Executivos da NOVACAP, sendo ele o membro escolhido dentro da lista tríplice udenista, como citado;

- A superposição das ações dos governos estadual e federal, que podem ter gerado conflitos de interesses políticos, quanto à prioridade e melhor instrumentalização do processo;

- A própria indefinição político-administrativa do território do Distrito Federal que só se constitui em 1960;

Portanto, uma avaliação quanto ao sucesso do processo de aquisição teria de buscar não só nos depoimentos importantes e esclarecedores de personagens como Altamiro Pacheco e

\footnotetext{
${ }^{117}$ Estabelecida por decreto já citado onde previa também a indenização ao estado de Goiás pelas terras já adquiridas. A valores atualizados a 31/12/2007 pelo INCC-DI FGV R\$30.203.478,38.
} 
Ernesto Silva, entre tantos outros, mas antes de tudo na importância da terra na sociedade brasileira. No âmago dessa discussão está a questão agrária.

Nos depoimentos e na pesquisa documental sobre os processos de aquisição de terras da Comissão de Cooperação e NOVACAP, fica clara a dificuldade em estabelecer a relação de domínio da terra, em contrapartida à posse.

Como registrado pelo engenheiro Joffre Parada nos relatórios da Comissão de Cooperação precisamente 100 anos (1855-1858 a 1955-1958) separaram a primeira organização de registros ${ }^{118}$ na região e o levantamento da comissão, o que provocou um número indeterminado de tipos de situações conflituosas entre domínio e posse, entre transferências registradas em cartório ou manutenção de posse da terra com possibilidades de transferência por usucapião.

O universo de análise é imenso e todo ele regido pela mesma lógica que privilegia a precariedade do registro, isso independente do sujeito desse processo, do latifundiário ao pequeno produtor. Não se pode deixar de ressaltar que boa parte da região era composta de grandes fazendas e não necessariamente de grandes produtores, mesmo que alguns o fossem, já que a economia aqui gerada era baseada na pecuária e agricultura de baixo desempenho e média produtividade.

Parte-se do princípio que é a forma precarizada da propriedade (domínio e posse) ${ }^{119}$ que influi no processo de estruturação do território, anterior ou posterior a 1955, 1960 ou 1965. Mesmo porque hoje, no Distrito Federal como em qualquer outra região do Brasil, ainda se observa o hábito de transferência de posse sem registro, com os famosos "contratos de gaveta", levando ao "adquirente" a crer que esse tipo de documento possa lhe garantir "algum direito". Como José de Souza Martins afirma, uma forma de inclusão na nova desigualdade.

\subsection{A construção do espaço da nova capital}

Não era uma região deserta em meio ao absoluto nada que se marcou um lugar como tomando

\footnotetext{
${ }^{118}$ Registros Paroquiais estabelecidos pela Lei de Terras de 1850

${ }^{119}$ Ver MARTINS, José de Souza. Exclusão Social e a Nova Desigualdade.
} 
posse. Já existiam povoados e cidades anteriores: Planaltina (1859), Brazlândia (1934) que se constituíram em povoamentos contidos do novo Distrito Federal; e Luziânia (1746), Formosa (1843) e Planaltina de Goiás $(1790)^{120}$, núcleos urbanos no entorno a pouco mais de $25 \mathrm{~km}$ da divisa. Estes últimos são os municípios que perderam área para formação do Distrito Federal.

A existência de uma população com vida social e econômica voltada à exploração agrícola e pecuária marca uma pré-condição poucas vezes citada. Segundo dados da CODEPLAN/IBGE, em 1957, eram 12.283 habitantes representando uma densidade humana de 2,1 habitantes por quilômetro quadrado. Em três anos esse território que define o Distrito Federal, atinge um contingente populacional de 140.164, espalhados em nove aglomerados, Plano Piloto, Taguatinga, Gama, Sobradinho, Núcleo Bandeirante, Cruzeiro, Candângolândia, Planaltina e Brazlândia, um incremento na ordem de 128.000 habitantes.

Em apenas 47 anos de existência a população saltou para espantosos 2,3 milhões de habitantes, e, se considerados os municípios que compõe o entorno imediato do Distrito Federal, são mais de 3 milhões de habitantes.

No decorrer do processo de formação desse espaço, constituíram-se 15 núcleos urbanos ${ }^{121}$ divididos em 26 regiões administrativas, sendo que 22 deles foram criados e fomentados criados pelo poder público. Na estruturação desse espaço urbano pode-se destacar que Taguatinga, Ceilândia, Samambaia e Guará representam uma conurbação clara com mais de um milhão de habitantes.

A transformação econômica da região do planalto central que se dá pela construção da capital federal nos primeiros anos, 1955 a 1964, é impulsionada pelo setor econômico da construção civil que, a partir desse período vai diminuindo a participação na economia dando lugar ao setor público e vai sendo substituído na década de 80 pelo setor terciário.

\footnotetext{
${ }^{120}$ O municio de Planaltina de Goiás é o resultado do desmembramento do município de Planaltina cuja a sede, Planaltina, ficou dentro do Distrito Federal.

${ }^{121}$ Há uma distinção clara entre a autonomia administrativa que alguns setores dos núcleos originais conseguiram, e sua apartação quanto continuidade urbana, já que parte das Regiões administrativas hoje instaladas forma originadas de um desmembramento administrativo, devido a características urbanísticas e populacionais distintas. Por exemplo, Setor Sudoeste, Lago Sul e Norte, que eram parte integrante do Plano Piloto, entre outros casos.
} 
Mas é impossível ter alguma fórmula econômica em Brasília que prescinda da participação do Estado e por isso, qualquer política de investimento ou mesmo de arranjos para a economia local com características liberais, ou até neo-liberais, não se sustenta, já que todos os setores da economia se estruturaram a partir de investimentos estatais. Os exemplos em contrário, são poucos e solitários dentro de todos os setores.

Independente da política marcada pelo nacional-desenvolvimento como exposto anteriormente, a matriz base de Brasília é sua função político-administrativa nacional (poderia extrapolar o raciocínio final para uma visão nacional?)

No caso do urbanismo, a política de uso e ocupação do solo e a reestruturação urbana, sempre estiveram a cargo do Estado e o planejamento urbano modernista se tornou uma ferramenta fenomenal nesse sentido. Seu discurso estruturador é segregador, como todo planejamento com viés modernista que busca a setorização e separação das funções e usos. Isso não o torna necessariamente um planejamento que acirre a desigualdade social, mas pode ser facilmente utilizado para tal.

O que pode corroborar a interpretação do acirramento das desigualdades é tomar dois pontos de vista para observar o resultado dessas aglomerações. O primeiro e o do passante, onde a diferença se faz de forma clara, onde as regiões mais periféricas carregam em si a marca da autoconstrução, da construção civil banal, pela menor quantidade de área pública em comparação com as áreas mais centrais. O contraste se torna brutal observada a característica das construções modernistas e simbólicas, que fazem de Brasília um conjunto de uma plasticidade única e patrimônio da humanidade.

O segundo ponto de vista é o do urbanista, que vendo pela linguagem da prancheta vê o território sem perspectiva, plano. E a partir desse ponto de vista, observa algo surpreendente: $80 \%$ desse território é planejado, organizado, setorizado, onde estão previstas de forma eqüidistante, em muitos casos, escolas, creches, postos de saúde e hospitais. As ruas simetricamente desenhadas, hierarquizadas seguindo preceitos técnicos rodoviários, com os devidos usos destinados. Não é impressão, mas a realidade com a qual se buscou marcar a construção da capital, o território era um plano "em branco".

\subsubsection{Evolução da ocupação urbana}

Pode-se verificar tanto pelos dados coletados sobre a evolução urbana de Brasília, como pelo 
estudo bibliográfico ${ }^{122}$ que existe claramente uma forma de observar o crescimento do aglomerado urbano de Brasília, tendo em vista o processo de produção do espaço urbano e os atores a ele vinculados, e uma periodização é possível de ser determinada e assumida para princípio de análise, tendo como ponto de partida o Plano Piloto de Brasília de Lúcio Costa:

1957 - 1964: Neste período a produção do espaço urbano do Distrito Federal segue sob a forte interferência do Estado, por meio da produção da NOVACAP e produção de organismos como os Institutos de Aposentadoria e Previdência, tendo um momento de refluxo de investimentos no período de 1961 a 1964, marcado pelos conflitos políticos quanto à mudança administrativa de Juscelino para Jânio e àqueles que resultaram no golpe militar de 1964. Em 1962 é criada a Sociedade de Habitação Econômica de Brasília - SHEB, que em 1964 passa a se chamar de Sociedade de Habitações de Interesse Social - SHIS (juridicamente a razão social só muda em 1966). Concurso do Plano Piloto de Brasília em março de 1957.

1964 - 1976: Há uma retomada de investimentos na capital, com a introdução de uma nova forma de financiamento a investimentos oriundos dos programas do recém criado Banco Nacional de Habitação - BNH. Neste período há uma proliferação e diversificação de atores no mercado imobiliário com a introdução de forma organizada do empresário da construção civil, como incorporador independente dos contratos governamentais. Ele se torna empreendedor imobiliário. Nesse mesmo período se define a política habitacional do Distrito Federal para as classes de mais baixa renda por meio da Sociedade de Habitações de interesse Social - SHIS (antiga SHEB). No campo dos planos o Plano Diretor de Águas, Esgoto e Controle da Poluição do DF (PLANIDRO) de 1970 é referência importante.

1977 - 1987: Marca o início da utilização de modelos de planejamento do território, por meio dos Planos de Ordenamento. É deste período o Plano Estrutural de Organização do Território do Distrito Federal - PEOT (1978), o Plano de Ordenamento do Território - POT e o Plano de Ordenamento do Uso e Ocupação do Solo - POUSO. No campo administrativo e político é a autonomia política do Distrito Federal que marca o fim desse período, criando um novo aparato legal e instância legislativa própria do território que modificaram e influenciaram uma nova gestão do planejamento. O relatório de Lúcio Costa contratado pela TERRACAP, Brasília: Revisitada de 1986, já marca o fim desse período e o início do posterior.

122 Como FICHER, plano de trabalho de "Brasília e seu plano piloto", BATISTA et al., "Brasília: uma história de planejamento" e LEITÃO “Do risco à cidade: as plantas urbanísticas de Brasília, 1957-1964". 
1987 em diante: Pode-se dizer que o marco desse período é a preservação urbana e autonomia política, somados aos instrumentos dos períodos posteriores (Planos de Ordenamento que agora se transformam em instrumentos legais e não apenas em peças técnicas-administrativas, e a preservação e proteção ao meio ambiente). Com executivo e legislativo eleitos de forma direta se delineia uma nova relação de poder e política em Brasília. A preservação urbanística do Pano Piloto se torna mais uma componente desse cenário. (Brasília: Revisitada de 1987 e o tombamento de Brasília como Patrimônio Cultural da Humanidade

Essa periodização corrobora para um entendimento mais geral do quadro urbano do Distrito Federal auxiliada pelo Mapa III. Opta-se nesse trabalho observar aos resultados do conjunto de instrumentos de planejamento mais do que uma análise das diretrizes e diferenciações entre eles. Por isso faz-se um panorama dos instrumentos de planejamento urbano, os quais acabam por confirmar, um após o outro, o processo de ocupação que é o resultado do planejamento estatal do Distrito Federal.

Uma concepção que ajuda a definir a ocupação do quadrilátero e que também contribui para um entendimento do processo da evolução urbana, tem a ver com a preservação da Bacia do Lago Paranoá, intimamente ligada à preservação do Plano Piloto. Toda a ação de Planejamento e ocupação do território do Distrito Federal respeitou essa condição, que se torna princípio de planejamento urbano estatal em Brasília.

Como registrado em publicação:

"De certa forma, a proteção à bacia do Paranoá norteia todas as diretrizes de planejamento territorial do Governo do Distrito Federal o que, em última instância, resulta na ocupação urbana esparsa e fragmentada do DF. Assim, a cidade apresenta uma estrutura sem continuidade de sua malha urbana onde os espaços que separam os seus diversos núcleos possuem, via de regra, alguma implicação de ordem ambiental. "123

${ }^{123}$ SEDUH - Modelo de Gestão do território do Distrito Federal. Pg.116 
MAPA III Evolução urbana do Distrito Federal

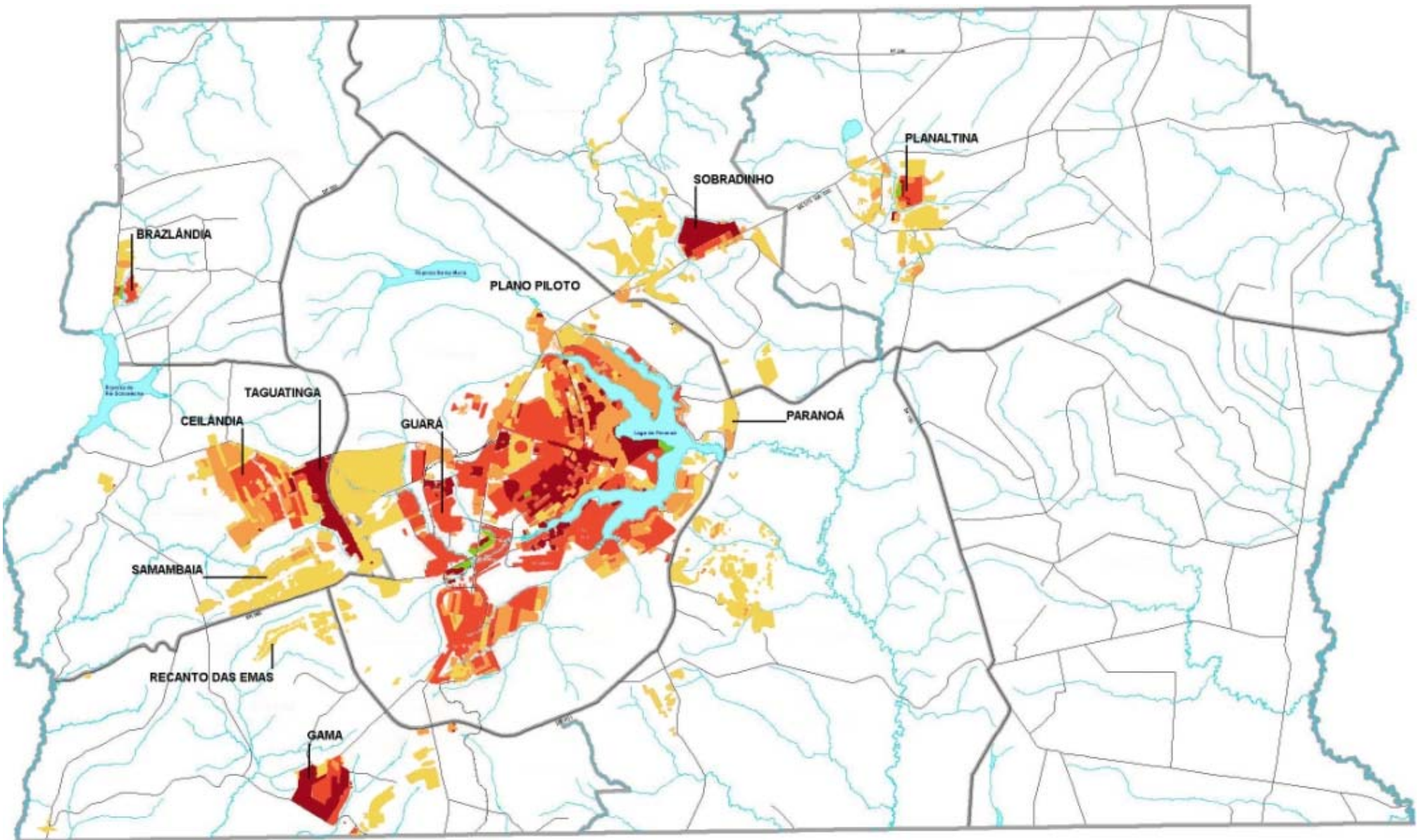

\section{Ocupação urbana:}

Anterior à década de 60 Durante a década de 60

Durante à década de 70
Durante a década de 80
Durante à década de 90

Fonte: Secretaria de Estado e Desenvolvimento Urbano e Habitação (SEDUH) - Governo do Distrito Federal 2006 
Como registrado em publicação:

"De certa forma, a proteção à bacia do Paranoá norteia todas as diretrizes de planejamento territorial do Governo do Distrito Federal o que, em última instância, resulta na ocupação urbana esparsa e fragmentada do DF. Assim, a cidade apresenta uma estrutura sem continuidade de sua malha urbana onde os espaços que separam os seus diversos núcleos possuem, via de regra, alguma implicação de ordem ambiental."124

Não existe dúvida quanto à importância das questões ambientais postas, já que no território do Distrito Federal se encontram nascentes das três maiores bacias hidrográficas do Brasil, o que é simbolicamente marcante, sendo uma das bandeiras ambientalistas. Na figura a seguir está inserida a quadro da evolução urbana sob uma base de bacias hidrográficas. além disso, no mesmo relatório destaca-se:

"As questões ambientais, hoje, estão no centro das discussões sobre a ocupação do território do Distrito Federal, fato que se evidencia quando cerca de $43 \%$ do território do Distrito Federal está inserido em alguma área de proteção ambiental e enfrenta algum tipo de restrição à sua ocupação, sendo que, em mais de $20 \%$ do território, há proibição de ocupação com finalidade urbana"

No âmbito da discussão ambiental, geralmente se adota o ano de 1970 como um marco importante da prática do planejamento urbano em Brasília. Neste ano é formulado o Plano Diretor de Águas, Esgoto e Controle da Poluição do DF, o qual ficou conhecido como PLANIDRO, devido ao nome da empresa que o elaborou. Consistia no macrozoneamento do território do Distrito Federal, com a preocupação de proteger a Bacia do Paranoá, criando uma zona de controle de adensamento populacional e estabelecendo um limite quanto à população residente nesse perímetro.

Este plano contratado pela Companhia de Água e Esgoto de Brasília - CAESB serviu como base de planejamento dos investimentos e obras de saneamento do Distrito Federal e, ainda é um documento técnico recorrente nas análises da Bacia do Paranoá.

Vale ressaltar que ao ratificar a "Faixa Sanitária"125 estabelecida pelo Departamento de

${ }^{124}$ SEDUH - Modelo de Gestão do território do Distrito Federal. Pg.116

${ }^{125}$ A "Faixa Sanitária", assim nomeada por seus idealizadores, possui $120 \mathrm{~km}$ de extensão. Hoje, essa faixa corresponde Estrada Parque Contorno - EPCT, anel rodoviário do DF, tendo sido estabelecida e construída já nos primórdios da construção da nova capital, com a preocupação explicita de preservação do futuro da Bacia do Lago Paranoá. O autor de tal proposição foi Joaquim Alfredo da Silva Tavares, primeiro diretor do DTA, em conjunto com: eng. Inácio Lima Ferreira, 
Terras e Agricultura - DTA da NOVACAP, consolida, via documento técnico, um isolamento do Plano Piloto com relação ao restante do território reforçando um padrão de ocupação do território que vinha desde de 1958 a partir da localização e implementação de Taguatinga.

As políticas e práticas do Estado legitimam uma ação de ocupação urbana periférica por meio de um documento de característica preservacionista em primeira e última análise, sanitarista, já que a argumentação se baseia na capacidade de absorção da carga de resíduos sólidos que a Bacia do Paranoá poderia comportar, mesmo tendo tratamentos adequados.

Em 1978, é aprovado o Plano Estrutural de Organização Territorial - PEOT, também reforçando e legitimando as tendências já determinadas anteriormente, vinculando as futuras ocupações a um sistema de transporte de massa e as condições de infra-estrutura para o abastecimento de água e esgotamento sanitário.

Considera-se que este plano formula as bases para os planos posteriores, já que determina o macrozenamento de todo o território do Distrito Federal, com uma forte influencia das questões ambientais. Tais tendências reforçam o que já havia sendo utilizado como diretriz de ocupação do território expressa no PLANIDRO.

Indicava, no seu ordenamento territorial, a expansão da cidade a partir dos custos de infraestrutura, sendo fundamentais aqueles ligados ao abastecimento de água e da eliminação do esgoto doméstico.

Toda a análise técnica para suporte do PEOT baseou-se no que se denomina de Threshold Analysis, ou Análise de limiares, que se constitui na observação das limitações no tocante à topografia, usos da terra e infra-estrutura, buscando quantificar as limitações em termos de custos necessários à sua implantação. O forte viés financeiro determinava a solução e os

topógrafos Jayme Macedo Queiroz e Luiz Armínio, todos integrantes do departamento. Em sua curta duração, entre 6 de fevereiro de 1957 a 16 de maio de 1959, foi responsável pela caracterização de um dos limites físicos mais claros de segregação do planejamento do Distrito Federal, seus efeitos perduram até hoje, pois ainda é utilizado como argumentação que se opõe ao adensamento da área central face a questões ambientais. Todo o acervo e competências do DTA são assumidos pelo Departamento de Agricultura da Prefeitura do Distrito Federal, instituído em 1 de junho 1960. A que se pontuar também que o processo de desapropriação executado pela NOVACAP era realizado pelo DTA, vinculada ao Diretor Íris Meinberg (UDN). Esse mesmo departamento sofre inquérito administrativo sobre denúncias de irregularidades e malversação de dinheio público - ver trecho do inquérito em anexo. 
custos contabilizados mais avaliavam os impactos imediatos aos cofres públicos do que considerava a contrapartida social dos investimentos.

Seu formato se assemelha aos modelos DIOXADIS, com bons diagnósticos, apresentando alternativas para o crescimento. Indica diversos aspectos interessantes que ajudam a captar a percepção dos planejadores ao desenvolver o relatório como "a falta de organicidade dos traçados existentes" do desenho urbano. A essa organicidade, os autores se referem a um "tratamento integrado dos elementos do projeto, tendo em vista uma determinada topografia e orientação." ${ }^{126}$, numa referência que remete a preceitos da cidade-jardim de Howard.

Outro aspecto importante do estudo é que coube a Companhia de Água e Esgoto de Brasília - CAESB, a análise das três alternativas de ocupação de território do Distrito Federal, quanto aos aspectos de saneamento básico e ambiental, o que aparentemente pode ter influenciado na escolha da alternativa, já que, como registrado, à companhia é destinada a implantação e operação do sistema que foi estruturado tendo em vista o Plano Diretor de Águas e Esgotos (PLANIDRO - 1970).

Os modelos de limiares, ou como expresso dentro do documento técnico que deu origem ao PEOT, modelos de "saturação", baseavam-se na população limite, tendo em vista "critérios de natureza infra-estruturais relacionados com aspectos de poluição das bacias hidrográficas que circundam os núcleos urbanos" ${ }^{127}$. Essa população limite, esse ponto de saturação foi calculada em 2,4 milhões de habitantes. Em 2006 o DF possuía 2.383.614 habitantes aproximadamente, segundo estimativas da antiga SEDUH, hoje SEDUMA.

Há também referência sobre a forma de ocupação do solo no DF, considerada no relatório como uma ocupação notadamente de segregação espacial definindo baixas densidades com altos custos de implementação de infra-estruturas.

"Em Brasília, o problema da densidade apresenta-se primeiramente em plano global. A ocupação territorial atomizada e dispersa cria distâncias entre os núcleos que agem como barreiras à integração das partes da cidade. Essa segregação espacial tem como conseqüência estruturas urbanas pobres e mal providas de equipamentos." ${ }^{128}$

Ainda sobre as densidades,

\footnotetext{
${ }^{126}$ PEOT, 1977 volume II p. 293

${ }^{127}$ Idem, p. 77

${ }^{128}$ Ibidem p. 296
} 
“(...) A nível local as densidades líquidas para as áreas habitacionais apresentam variações significativas. A ocupação urbana mais densa ocorre no Plano Piloto, onde a média verificada para as superquadras é da ordem de 250 hab/ha., ${ }^{129}$

Nas outras localidades a densidade estava em torno de $128 \mathrm{hab} / \mathrm{ha}$.

Mas não há nota ou analise quanto à questão fundiária em todo o relatório, não é fundamento de análise, não representa papel importante quanto à constituição urbana em Brasília. Essa permanece a reboque de todas as análises do período, sem em nenhum momento representar questão importante de análise.

O que demonstra que as questões ligadas à propriedade fundiária, não faziam parte do "modelo" de planejamento estatal que ia se configurando em Brasília, mas se configurava em um modelo "imobiliário", já que é no período que se cria a Companhia Imobiliária de Brasília - TERRACAP, que passa a administrar do patrimônio fundiário estatal.

Em resumo, o PEOT, em primeiro lugar busca preservar os mananciais hídricos do São Bartolomeu e do Descoberto, pois creditava às micro-bacias destes rios a reserva futura para o abastecimento de água do DF, e, portanto, as ocupações nas cidades-satélites de Sobradinho e Planaltina, no caso da primeira micro-bacia, e Brazlândia, no caso da segunda, as quais deviam ter suas densidades e ocupações rigidamente controladas, e por isso, o processo de incremento populacional e expansão do território nesses dois sentidos, não seriam incentivados.

Em segundo lugar, proteção da Bacia do Lago Paranoá

“(...) posto que o lançamento de esgotos sanitários ou mesmo pluviais nesta bacia poderia vir a ampliar, de forma ainda não mensurável, os danos já verificados de eutrofização do lago. Do mesmo modo, o dimensionamento do sistema de esgoto sanitário, principalmente no que se refere às duas estações de tratamento atualmente em construção, não permite a alocação de mais população nessa bacia. Por outro lado, esse problema poderia ser solucionado através da construção de um emissário de que exportaria os esgotos sanitários para outra bacia, permanecendo apenas a contribuição das águas superficiais para o Paranoá. Essa hipótese poderia ser focada através do comparativo entre custos de implantação e manutenção deste equipamento, e da diminuição considerável tanto dos custos de transporte quanto do próprio custo social com que viria a arcar a população locada a maiores distâncias do Plano Piloto."130

\footnotetext{
${ }^{129}$ PEOT, volume II p. 297

${ }^{130}$ Idem, p. 130 (grifo nosso)
} 
Mas, a solução adotada, buscou a alternativa apresentada que concentra as ocupações do território na parcela sudoeste, o que leva a crer que o custo social a que se refere o relatório pode não ter sido contabilizado e uma opção de adensamento nas regiões periféricas já implantadas assumida.

Nos anos 80 surgem o Plano de Organização do Uso do Solo Urbano - POUSO e o Plano de Ordenamento Territorial - POT, ambos, planos de macrozoneamento, seguindo os princípios de determinação de áreas para expansão urbana já delineados no PEOT, reforçando as questões de preservação ambiental.

O POT detalha o macrozoneamento do PEOT, com uma nova contribuição, a criação de um Sistema de Planejamento da Ocupação Territorial e um Conselho Consultivo com participação da sociedade.

O período entre 1984 e 1988 é importante para o entendimento das formas de ação do estado no planejamento urbano local, já que instaura um processo político nacional de anistia e abertura política com o fim do regime militar, finalizando com a autonomia política do território federal e a criação do poder legislativo local. As decisões legislativas e orçamentárias se deslocam da comissão especial do Senado no Congresso Nacional para uma casa de representação política local, essa deslocamento é importante pois muda a forma de atuação política do executivo local.

Além disso, o fim do BNH em 1986 representa uma grande mudança na política local de planejamento e habitação, tendo em vista que como agente financiador contribuiu com o processo de formação e consolidação da capital.

Em 1992 entra em cena o primeiro Plano Diretor de Ordenamento Territorial - PDOT que é revisado em 1997. Neste mesmo ano a Fundação Zoobotânica, responsável por todo o patrimônio imobiliário rural do poder público é extinta, e o processo de parcelamento do solo executado pelo governo local se utilizando da distribuição de lotes semi-urbanizados é iniciado. São 20.424 lotes em diversas regiões do Distrito Federal.

Os PDOT marcam uma distinção importante, pois já estão dentro de uma nova estrutura administrativa e política do Distrito Federal, que se torna autônomo com legislativo próprio em 1987. Outra característica vital, assumem a complexidade da situação fundiária, consolidando uma nova forma da administração pública encarar o problema, admitindo o parcelamento de terras por particulares e garantindo mecanismos de regularização. Como instrumento da política de planejamento urbano representa uma visão que vai se 
aproximando da cidade real.

Em 28 anos nada menos que seis ${ }^{131}$ planos de macrozoneamento e ordenamento de território do Distrito Federal, aos quais pode-se somar o Brasíllia Revisitada de Lúcio Costa de 1987, que tem o grande mérito de estabelecer áreas para ocupação urbana dentro do perímetro de adensamento restrito determinado pelo Plano de Águas, dentro da Faixa Sanitária portanto, e o fato importante para preservação do Plano Piloto, o tombamento da cidade por meio da declaração da UNESCO dando a Brasília o título de Patrimônio Cultural da Humanidade em 1987.

Há que se ressaltar ainda que o Brasília Revisitada de Lúcio Costa, observado o mérito exposto, acaba mais por sinalizar novas regiões para o investimento do capital de grandes empreendedores capitalistas dentro de uma área exclusiva, pois não determina, e não era o objetivo do relatório contratado, estabelecer formas de controle e garantia de acesso universal à moradia.

O relatório cria uma nova fronteira de investimento do capital imobiliário na área preservada, e que tem no Estado, por meio da Companhia imobiliária de Brasília - TERRACAP, um parceiro agente participante e extremamente poderoso, pois cria valor em áreas antes destinadas à escala bucólica e extrai lucro da venda dos imóveis que serão parcelados.

Apesar da crítica que se faz aos últimos Planos Diretores, os PDOT (1992 e 1997) carregam em si duas características importantes: A primeira, a quebra do monopólio estatal no processo de loteamento do solo, permitindo à iniciativa privada precedê-lo quando se trata de propriedade privada confirmada e não contestada pela autoridade local, respeitado o macrozoneamento e as diretrizes lançadas pelo poder público.

A segunda característica é a criação dos Planos Diretores Locais, atribuindo às Administrações Regionais das cidades satélites, em conjunto com o órgão planejador, o processo de planejamento urbano. De certa maneira, esse novo instrumento possibilita uma observação mais focal das cidades, dada suas características de ocupação do solo, organização social e econômica.

Em 50 anos de formação da periferia do Plano Piloto, da estruturação das cidades-satélites,

\footnotetext{
${ }^{131}$ Está em curso a aprovação de um novo PDOT, o que aumenta a lista para sete, numa média de 3 anos e seis meses, somados todos os documentos que subsidiaram o planejamento estatal em Brasília. O que nos permite reafirmar que não foi a omissão do Estado, a ocupação atual pode ser considerada deliberada.
} 
é observada certa conformação social distinta e que se desenvolveu, em grande parte, a mercê do centro de empregos que fortemente se situa no Plano Piloto.

Os PDL têm como uma das tarefas buscarem arranjos econômicos na região administrativa que abrangem na tentativa de fortalecer a economia das satélites. Obviamente, essa tarefa perpassa o perfil dependente dos habitantes do DF em relação à estrutura do Estado, e as ações de incentivo local. Enfim, como recorrente na história da capital federal, todas elas dependem de subvenção do Estado, do Governo do Distrito Federal em primeira instância.

\subsubsection{A construção do Plano Piloto e o mercado da construção civil.}

"Em 1965 a empresa norte americana Westinghouse nomeou um grupo de 14 pessoas para realizar uma seleção sui generis. O seleto grupo, cujos nomes de seus integrantes não foram revelados, deveria escolher oitenta 'referências culturais' de destaque, produzidas entre os anos de 1940 a 1965. Elas seriam preservadas durante cinqüenta séculos numa cápsula. Os filmes, livros, textos de teatro, discos, programas de televisão, reprodução de quadros, esculturas e projetos arquitetônicos eleitos como representativos de uma civilização, foram enterrados em uma 'cápsula do tempo', em 16 de outubro de 1965, durante a última feira mundial de Nova lorque. Nessa 'cápsula do tempo Brasília sua arquitetura e Plano Urbanístico - é a única referência cultural que representa o Brasil."132

Provavelmente o período mais marcante para a consolidação de Brasília como cidade, e, por conseguinte, capital federal tenha sido entre 1961 e 1968, não só pela questão da instauração de regime militar em 1964, mas também pela controvérsia que gerava.

E a controvérsia nacional era gerada tendo como imagem, ou arena de disputa o Plano Piloto de Brasília, o qual era identificado por determinados grupos como obra de expressão artística e desenvolvimentista máxima da cultura brasileira, em uma conotação positiva, e, por vezes, como cidade fria, desolada, sem atrativos, fruto de um mau gosto sem precedentes, como declarava Max Bill em sua vinda ao Brasil na década de 50.

Não é, entretanto, sob este prisma que se pretende fazer a análise, pois a melhor expressão

132 RODRIGUES, Georgete Medleg. Ideologia, Propaganda e Imaginário Social na construção de Brasília. Dissertação de Mestrado. Departamento de História - Universidade de Barsília UnB, 1990.pg xi 
de Brasília está na maneira sui generis que se construiu o espaço urbano. A grande participação estatal na consolidação da capital federal marca o pensamento desenvolvimentista da época e uma forma de atuação do Estado no urbano. Como Paulo Bicca manifesta:

“(...) somente uma postura redutora seria capaz de identificar as relações entre capitalismo e a produção da cidade, apenas sob a ótica da especulação imobiliária, como se essa não fosse apenas um das tantas formas aparentes sob as quais ao mesmo tempo se revela e se esconde aquilo que é essencial à produção capitalista do espaço e que somente aparece quando revelamos as relações de produção que ocorrem sob a égide do capital, as quais necessariamente não exigem o que se costuma identificar sob as expressões de especulação imobiliária, posto que destas independem, muito embora em várias situações ambas se completem."133

Não é apenas sob a ótica do que comumente se identifica como especulação imobiliária que se apresenta a lógica capitalista, e por isso a opção por uma abordagem sobre a ação estatal na produção do espaço urbano da capital é realçada agora.

Essa escolha fundamenta-se na quantidade bem documentada de agentes estatais envolvidos diretamente na produção física desse espaço, e o período escolhido como referência é o que vai até 1974, com especial atenção entre 1964 e 1969.

Esse período marca o reconhecimento da ação ainda incipiente, mais do que um surgimento, do empreendedor privado como incorporador imobiliário. Não é intenção observar a pequena produção ocorrida de forma esparsa, ou seja, a produção de pequenos agentes da construção civil em ações isoladas, que em sua maioria tem como princípio produzir a moradia própria. O que interessa é observar o agente imobiliário que incorpora.

A transição entre o empreendimento meramente estatal, ou mesmo sob forte domínio das organizações estatais, e a entrada do agente privado marca uma forma importante de perceber as relações que se estabelecem em Brasília

Em princípio, toda a produção imobiliária, mais precisamente, a maior parte da produção imobiliária em Brasília, especificamente no Plano Piloto, se dá por meio do setor estatal. São vários agentes contribuindo para a produção do espaço central da nova capital e alguns deles serão destacados aqui.

Para se ter uma idéia dessa produção segue a tabela demonstrando a participação do

${ }^{133}$ BICCA, pg 103 
agente privado e do agente estatal entre 1966 e 1974 no Distrito Federal em número de unidades habitacionais produzidas.

TABELA III. Quantidade de unidades habitacionais produzidas pelas setores público e privado entre o período de 1966 a 1974.

\begin{tabular}{|c|c|c|c|c|c|}
\hline \multirow{2}{*}{$\frac{\text { Ano }}{1966}$} & \multicolumn{2}{|c|}{ Setor Público } & \multicolumn{2}{|c|}{ Setor Privado } & \multirow{2}{*}{$\begin{array}{l}\text { Total/Ano } \\
3.410\end{array}$} \\
\hline & 3.410 & $100,00 \%$ & 0 & $0,00 \%$ & \\
\hline 1967 & 1.239 & $100,00 \%$ & 0 & $0,00 \%$ & 1.239 \\
\hline 1968 & 7.649 & $90,31 \%$ & 821 & $9,69 \%$ & 8.470 \\
\hline 1969 & 3.799 & $81,61 \%$ & 856 & $18,39 \%$ & 4.655 \\
\hline 1970 & 5.679 & $91,63 \%$ & 519 & $8,37 \%$ & 6.198 \\
\hline 1971 & 2.819 & $96,74 \%$ & 95 & $3,26 \%$ & 2.914 \\
\hline 1972 & 7.542 & $90,15 \%$ & 824 & $9,85 \%$ & 8.366 \\
\hline 1973 & 11.569 & $96,26 \%$ & 450 & $3,74 \%$ & 12.019 \\
\hline 1974 & 10.675 & $87,04 \%$ & 1.589 & $12,96 \%$ & 12.264 \\
\hline TOTAL & 54.381 & $91,34 \%$ & 5.154 & $8,66 \%$ & 59.535 \\
\hline
\end{tabular}

Fonte: CODEPLAN - Diagnóstico do Setor de Habitação / 1970 e Anuário Estatístico do Distrito Federal /1975

TABELA IV. Investimentos dos IAP em Brasília (total acumulado até 31/12/1965)1 em unidades residenciais e em imóveis para próprio funcionamento.

\begin{tabular}{lllll}
\hline & \multicolumn{2}{l}{ Em unidades residenciais } & \multicolumn{2}{l}{$\begin{array}{l}\text { Em imóveis para o próprio } \\
\text { funcionamento }\end{array}$} \\
\hline & Terrenos & Obras & Terrenos & Construções \\
\hline IAPI & $2.339 .296,33$ & $45.449 .191,95$ & $169.786,12$ & $\mathbf{1 1 . 5 7 7 . 1 6 6 , 0 0}$ \\
\hline IAPC & $656.631,42$ & $41.668 .395,08$ & $70.353,37$ & $\mathbf{5 . 6 3 4 . 8 1 3 , 2 2}$ \\
\hline IAPB & $792.706,50$ & $44.901 .245,0$ & $407.258,72$ & $\mathbf{6 7 . 0 6 9 , 7 9}$ \\
\hline IAPFESP & $328.315,71$ & $12.836 .191,05$ & - & - \\
\hline IAPM & $174.753,07$ & $9.265 .439,42$ & 81.64290 & $\mathbf{4 . 2 5 3 . 0 0 5 , 5 0}$ \\
\hline IAPETC & $328.315,71$ & $7.957 .809,95$ & - & - \\
\hline Total & $\mathbf{4 . 6 2 0 . 0 1 8 , 7 3}$ & $\mathbf{1 6 2 . 0 7 8 . 2 7 3 , 0 5}$ & $\mathbf{7 2 9 . 0 4 1 , 1 1}$ & $\mathbf{2 1 . 5 3 2 . 0 8 1 , 5 1}$ \\
\hline
\end{tabular}

${ }^{1}$ Em R\$ de junho de 1998.

Fonte: SEDUH (2004) reproduzindo dados Boletim do MITC (1966) in Oliveira, Beltrão e David 1999

Neste universo, um conjunto de atores estatais preponderantes para a constituição do espaço é o composto pelos Institutos de Aposentadoria e Previdência - IAP. Até 1964 foram 
responsáveis por nada menos que 7.315 unidades habitacionais que segundo Nabil Bonduki $^{134}$ ao observar os números da pesquisa de Marta Farah ${ }^{135}$, representou nada menos que $9,6 \%$ de toda a produção no período que vai de 1937 a 1964 . Tendo em vista, ainda, que essa produção ocorreu no período entre 1957 a 1964, os números se tornam mais expressivosA atuação dos Institutos de Aposentadoria e Pensões, no setor da habitação, tem seu ponto de partida na criação de suas carteiras prediais em 1937, até então, como relata Bonduki, os IAP destinam seus recursos quase que exclusivamente para aquisição de título da dívida publica.

Estes institutos atuaram seguindo um modelo implantado pelo Instituto de Aposentadoria e Pensões dos Industriários - IAPI, como descrito por Farah, que dividia suas operações em três tipos de planos:

Plano A: Arrendamento ou venda de unidades habitacionais em conjuntos residenciais adquiridos ou construídos pelos institutos, com o objetivo inicial de proporcionar aos associados moradia digna, sem prejuízo da remuneração mínima do capital investido;

Plano B: financiamento para aquisição da moradia ou construção de habitações por iniciativa dos associados. (ver portaria $\mathrm{n}^{\circ} \mathrm{SCM}-192$ 28nde novembro de 1939) em terreno próprio

Plano C: operações imobiliárias diversas, como empréstimos hipotecários feitos a qualquer pessoa física ou jurídica, bem como outras operações imobiliárias que o instituto julgasse conveniente, no sentido de obter uma constante e mais elevada remuneração de suas reservas;

As condições de financiamento que se estabeleciam, resumidamente, são as seguintes:

- Prazo de financiamento de 25 anos

— Taxas de juros de $6 \%$ ao ano sem correção monetária

No contexto da produção imobiliária da nova capital, esse estoque criado pelos institutos representava a reserva de imóveis funcionais do Estado. Por vezes vendidos diretamente ao funcionário público, por vezes administrado como imóvel a ser concedido por prazo

\footnotetext{
${ }^{134}$ BONDUKI, Nabil Georges. Origens da habitação social no Brasil: Arquitetura moderna, lei de inquilinato e difusão da casa própria. 2. ed. São Paulo: Estac Liberdade, 1999

${ }^{135}$ FARAH, Marta Ferreira Santos. Estado, previdência social e habitação. São Paulo, dissertação de mestrado, 1983. $189 \mathrm{f}$
} 
determinado aos ocupantes dos cargos especiais, e cargos do segundo ou terceiro escalão de governo.

Para dar conta do estoque é criada em 28 de fevereiro de 1967 a Coordenação de Desenvolvimento de Brasília - CODEBRÁS que administrava o Fundo Rotativo Habitacional de Brasília (FRHB). O FHRB era constituído do resultado líquido das alienações dos imóveis residenciais, situados em Brasília, do INPS, do IPASE, de Sociedades de Economia Mista e das Caixas Econômicas Federais, sendo este patrimônio uma das fontes de financiamento da instituição. Possivelmente por administrar esses imóveis essa instituição foi credenciada pelo $\mathrm{BNH}$ na categoria de instituto de previdência, já que a maior parcela da participação do capital financeiro do FRHB provinha da venda de imóveis dos Institutos de Previdência que construíram parcela considerável das habitações do Plano Piloto, sendo o Fundo gerido pela CODEBRÁS,

Assim, a CODEBRAS se encarregava de orientar, planejar, coordenar, executar e controlar as atividades inerentes à transferência para Brasília dos órgãos do Governo Federal, em substituição ao Grupo de Trabalho de Brasília - GTB , sendo supervisionada pelo Grupo Executivo da Complementação da Mudança de Órgãos da Administração Federal para Brasília - GEMUD

É expressiva a participação das instituições ligadas a CODEBRAS, no tocante à construção do núcleo urbano do Plano Piloto ${ }^{136}$, que, até 1964 haviam sido produzidas 7.315 unidades habitacionais ${ }^{137}$, e entre 1966 e 1969, foram responsáveis por nada menos que $30,5 \%$ do número de ofertas de unidades habitacionais na cidade, representando $43,2 \%$ da área construída global e $47,8 \%$ dos investimentos do setor.

São 6.120 apartamentos construídos no Plano Piloto só no período $1966-69$, destinados quase que exclusivamente a funcionário públicos federais, num montante de investimentos de NCR\$ 211.199.632,00 (valores de 1968), que atualizados a 31/12/2007 seriam nada menos que $\mathrm{R} \$ 764.375 .958,20$. Ao todo os institutos de aposentadoria, ligados a

\footnotetext{
${ }^{136}$ Incluía-se na distinção do período o Cruzeiro que ainda não era Região Administrativa. Plano Piloto até então era Asa Sul, Asa Norte,Cruzeiro, Lago Sul e Lago Norte.

${ }^{137}$ Dados coletados do Inventário da ação governamental dão conta de mais unidades, tendo como dat referência 1966, nele a contabilidade é a seguinte: IAPI (3.036); IAPFESP (432); IAPB (1.779); IAPTEC (600); IPASE (828); e IAPM (420), num total geral até 1966 de 9.435 unidades habitacionais, se somados então com as 6.120 computadas no período de 1966-1969 os números se elevam para 15.555 unidades habitacionais.
} 
CODEBRAS, produziram 13.455 unidades até 1969.

Os recursos utilizados eram de toda ordem, advinham do setor público e de financiamentos internos e externos obtidos para cumprir o Plano Diretor de Transferência. Além disso, varias ações do setor público faziam parte desse plano e não eram computados como recursos diretos mas como "meio", como ação interna e orçamento do órgão específico. Ou seja, não entravam na conta da CODEBRAS.

A criação da CODEBRAS marca uma posição importante no mercado imobiliário do Distrito Federal, já que os imóveis construídos por essa coordenação utilizando os recursos provenientes do Fundo de Habitação do $\mathrm{BNH}$, (fala aqui de imóveis adquiridos de acordo com a lei n. 4380 , artigo $65^{\circ}$ parágrafo $4^{\circ}$ e $5^{\circ}$ ) passaram a não mais fazer parte do mercado formal de compra e venda, sendo destinados à alienação para os funcionários públicos federais, lotados em caráter definitivo no Distrito Federal.

Imediatamente todas as unidades que se encontravam a disposição do mercado formal, as quais ainda não haviam sido efetivados os contratos de compra e venda, são adquiridas pela União que repassa os recursos ao FRHB. Exclui-se do mercado então, a partir daquele momento, quase um terço da produção de imóveis em Brasília.

O Estado cria um estoque de imóveis na parte central da capital, garantindo o que poderíamos identificar, em primeira instância, como sua condição de materialidade, mas, em sentido inverso provoca o estrangulamento do mercado imobiliário, diminuindo sobremaneira a oferta também de terrenos. Ou seja, essa exclusão de um grande número de imóveis do mercado formal pode ser um dos fatores explicativos que provocaram a valorização crescente dos terrenos que ficaram a disposição do mercado formal.

Essa valorização de imóveis no Plano Piloto é um dos fatores indicados por Gonzales ${ }^{138}$, que compuseram o que identifica como forma concreta de segregação residencial em Brasília, com a constante periferização. Mesmo que essa autora não tenha mapeado as causas da valorização, certamente aquela acima apresentada pode ser identificada como um dos componentes. Não se pode ignorar também que o mercado de oferta de terrenos novos era de domínio das companhias estatais NOVACAP e posteriormente TERRACAP.

Em contrapartida a essa exclusão, os beneficiários da lei, tinham à sua disposição imóveis

${ }^{138}$ GONZALES, Suely Franco Netto. As formas concretas da segregação residencial em Brasília in: PAVIANI, Aldo (org). Brasília, ideologia e realidade: Espaço urbano em questão. São Paulo: Projeto, 1981 
que poderiam ser alienados pelos funcionários em condições especiais ${ }^{139}$.

- Prazo de 25 anos

- Prestações mensais e sucessivas, compreendendo as cotas de amortização e juros de 5\% (cinco por cento) ao ano, pelo sistema Price, com taxas de administração de $2 \%$ sobre a quota de amortização. Isso representava uma prestação fixa sem correção monetária.

A partir do período de $66 / 69$, outro aspecto toma vulto, a origem dos recursos para os empreendimentos da CODEBRAS, que passam a ser quase que exclusivamente oriundos do BNH. Segundo a CODEPLAN, 93,5\% dos recursos investidos eram do BNH, seguidos dos recursos de outros órgãos públicos correspondentes a $5,2 \%$ e o restante $1,5 \%$ proveniente, do Fundo Rotativo Habitacional de Brasília - FRHB. Aponta para uma fantástica inversão de recursos para assegurar a transferência dos órgãos públicos para a capital federal.

Após oito anos de existência, em 1975, a competência, as atribuições legais, os recursos orçamentários e extra-orçamentários da Coordenação do Desenvolvimento de Brasília (CODEBRAS) e do Grupo Executivo da Complementação da Mudança dos órgãos da Administração Federal para Brasília (GEMUD), são transferidos a DASP que continua o gerenciamento das ações de alienação de imóveis a funcionários públicos federais.

No esforço de assegurar a transferência da capital, foram investidos até 31 de dezembro de 1961 nada menos que $\operatorname{Cr} \$$ 81.805.827.191,00 (a preços de dez/1961) por todos os órgãos e instituições públicas. A sindicância realizada no governo de Jânio Quadros é um elemento histórico importante, pois sistematiza um conjunto interessante de dados. A subcomissão de contadores da CPI criada conseguiu mapear uma série importante de dados. Atualizando valor Cr\$ 81.805.827.191,00, utilizando o INCC-FGV, já que é um dos poucos índices que possuem série histórica que abra o período de 1944 a 2008, são nada menos que R\$ $5.608 .780 .737,55$, valor atualizado a 31 de dezembro de 2007.

Outro agente importante no processo que entra no mercado como agente financiador do mercado imobiliário são as Caixas Econômicas Federais dos estados, centralizadas posteriormente. No período entre 1964 e 1970, a Caixa Econômica Federal de Brasília, CEFB, começa a operar, por meio de sua carteira de hipotecas financiando habitação tanto de particulares como de servidores públicos.

\footnotetext{
${ }^{139}$ Essas condições são estabelecidas em decreto-lei do presidente da república (decreto-lei $\mathrm{n}^{\circ} 703$, de 24 de julho de 1969)
} 
No caso dos servidores públicos a Caixa Econômica Federal de Brasília realizava convênios específicos com cada órgão governamental. Numa estratégia muito próxima à que hoje se utiliza para a realização de seus programas habitacionais, finaciava empresas de construção civil, exercendo a fiscalização da obra e das condições contratuais.

Entre 1966 a 1969 contribui com 10,7\% do número de habitações construídas no Distrito Federal, 2.158 unidades residências destinadas a funcionários públicos, sendo 1.566 apartamentos no Plano Piloto e 592 casas em Sobradinho. Se for considerada uma relação entre atendimento aos funcionários públicos e a particulares (264 unidades) ${ }^{140}$, é possível notar o grande direcionamento ao atendimento do setor público numa relação de 8 para 1.

Registra-se ainda um fato interessante, o valor médio de produção da CEFB, nesse período, é abaixo da média observada no setor habitação (NCR\$ 234,51/m² contra NCR\$ 244,85/m², quase $5 \%$ menor). Reforçando-se ainda que nesse período a CEFB, utilizou exclusivamente recursos de sua carteira de hipotecas para realizar os empreendimentos.

Além da CEFB, outras associações de poupança e empréstimos podem ser identificadas no período, como, por exemplo, a COLMÉIA APE, entidade de crédito, sendo a única atuar utilizando o Sistema Brasileiro de Poupança e Empréstimo - SBPE no período 66/69, produzindo 614 unidades residenciais a um custo final de NCR\$ 22.668.432,00 (a preços de 1968), ou $\mathrm{R} \$ 82.041 .830,60$ (a preços de 31 de dezembro de 2007 ) sendo que $63 \%$ desses recursos se originaram do $\mathrm{BNH}, 20 \%$ da poupança dos beneficiários e $16,7 \%$ da própria entidade.

Seu atendimento era destinado diretamente ao mercado, a particulares, todas as unidades, apartamentos e casas, foram produzidas na Asa Sul. Com o passar dos anos a Colméia se torna uma das associações de crédito mais atuantes em Brasília, responsável pelo financiamento e execução de unidades residenciais em várias cidades satélites, como Guará e Sobradinho.

Ainda encontram-se outros agentes públicos locais de crédito, como Banco Regional de Brasília - BRB, o mais significativo, atuando na execução do subprograma de Refinanciamento do Consumidor de Materiais de Construção - RECON.

\footnotetext{
140 Essa informação consta do documento de diagnóstico mas não é levada em conta na contabilização geral do período, assim no volume de 20.084 unidades, não estão contabilizadas as 264 unidades produzidas pela Caixa Econômica Federal de Brasília destinadas a atender a particulares.
} 
A NOVACAP estrutura governamental mais importante para viabilização da capital, coordenadora do processo de urbanização da capital, também atuou como agente empreendedor imobiliário produzindo unidades habitacionais, durante os primeiros anos da capital, atendendo à demanda por moradia de funcionários da administração local Governo do Distrito Federal e de funcionários federais, sempre por meio de convênios firmados entre as instituições e a companhia.

Atuava no papel de gerenciadora, contratando empresas especializadas para a execução de projeto e obra, fiscalizando e administrando todo o empreendimento, num modelo que transcendia o agente imobiliário incorporador, já que, também, era responsável por várias questões de acesso a crédito direto.

Segundo o diagnóstico da CODEPLAN:

"Das realizações levadas a efeito por essa instituição, no campo habitacional, é particularmente expressiva a parcela destinada aos seus servidores, o que significa estar em andamento programa específico de solução do problema da extrema carência de moradia com que se deparam os funcionários estaduais locais que, em sua maioria, residem em moradias provisórias e precárias. "141

Dentre os projetos levados pela NOVACAP, um interessante ser registrado é o "mutirão ou ajuda-mútua", destinado à produção de residências definitivas para os ocupantes dos antigos acampamentos ${ }^{142}$, o qual era realizado com financiamento do $\mathrm{BNH}$.

Mas, com recursos próprios, a NOVACAP empreende entre 1966 e 1969, 2.931 unidades habitacionais na Asa Sul e Norte, sendo que 2.709 unidades eram destinadas aos servidores do Governo do Distrito Federal e 222 unidades a funcionários federais. Representando assim, 14,6\% da oferta de habitação do período a um custo de produção de NCR $\$ 51.155 .489,00$ (preços de 1968), ou $R \$ 185.142 .490,79$ valores atualizados a 31 de dezembro de 2007 , sendo que $43 \%$ são recursos próprios e o restante das entidades conveniadas.

É importante notar a configuração do setor a partir de 1964. O cenário dos empreendimentos residenciais em Brasília torna-se mais complexo a partir a criação do

\footnotetext{
${ }^{141}$ CODEPLAN - 1970 pg 103

${ }^{142}$ Após a conclusão das grandes obras da cidade, os acampamentos das construtoras passam a ser administrados pela NOVACAP, fazendo parte do patrimônio da empresa que deve ser desmontado. No período de que trata esse relatório existiam aproximadamente 3 mil moradores nesses alojamentos.
} 
$\mathrm{BNH}$, agente financiador do processo, já que esse abre condições de acesso ao crédito de outros agentes que vinham se organizando.

Segundo dados da então Secretaria de Estado de Desenvolvimento Urbano e Habitação, entre 1970 a 1980, só por meio da Sociedade de Habitações de Interesse Social do Distrito Federal - SHIS, foram investidos aproximadamente 1,2 bilhão de reais (valores atualizados para 1998), em habitação e infra-estrutura com recursos do Sistema Financeiro Habitacional - SFH, produzindo algo em torno de 60 mil unidades habitacionais. No item seguinte o tema é abordado com mais detalhes.

Com o sistema criado com o surgimento do BNH tem-se a constituição de diversas cooperativas habitacionais, que iniciaram suas atividades em 1966, mais precisamente a partir de 06 de outubro de 1966, com o primeiro contrato de financiamento firmado com o Banco. São as primeiras cooperativas de Brasília, sendo elas:

- Cooperativa Nacional de Habitação do DF - COPENAL (atuou em Taguatinga)

- Cooperativa Habitacional dos Servidores do Senado Federal - COHASSEFE

- Cooperativa Habitacional da Associação Comercial do DF - COHABIBRÁS

- Cooperativa Habitacional dos Oficiais do Exército em Brasília - COHAEB

- Cooperativa Habitacional Santos Dumont dos Sub-oficiais, Sargentos e Servidores Civis da Aeronáutica, em Brasília

Produzindo 501 unidades residenciais até 1968, sendo 384 apartamentos localizados na Asa Sul do Plano Piloto e 117 casas em Taguatinga. Entre 1966 e 1969 são responsáveis por $4,3 \%$ do número de habitações ofertadas no Distrito Federal, representando um investimento de NCR $\$ 25.550 .780,00$ a preço de 1968 , $(\mathrm{R} \$ 92.473 .655,19$ atualizado a valores 31 de dezembro de 2007 ), do qual, $90 \%$ foi financiado pelo $\mathrm{BNH}$.

A historia da produção dessas cooperativas é pouco estudada, parcos são os documentos que se propõem a demonstrar essa participação, o que deixa um vazio importante na análise da produção do espaço em Brasília. Acredita-se que sua produção tenha chegado a 1.800 unidades habitacionais, só no período de 1966 a 1971, todas elas destinadas quase que inteiramente a funcionários da administração federal.

Aparentemente, a produção das cooperativas serve como bom balizador quanto aos valores de produção de habitação no Distrito Federal, segundo a CODEPLAN, no período que vai de 1966 a 1968, os valores médios de produção das cooperativas, por metro quadrado, eram $57 \%$ mais caros que a média verificada no Distrito Federal. Difícil é perceber quais foram os fatores que contribuíam para essa diferença, se a localização tem influencia, ou os 
custos de produção, ou outros fatores.

É de se lamentar a carência de estudos sobre este agente. Uma avaliação de suas ações posteriormente a esse período, até as incorporações das décadas de 80 e 90 se estendendo até os dias de hoje, em Águas Claras por exemplo, seria possível entender um agente importante do processo de consolidação do espaço urbano do Distrito Federal e participante do mercado imobiliário da capital. Essa avaliação poderia apontar para questionamentos importantes como a carência de oferta de habitações a preços mais acessíveis na década de 80 , que se tornou o período do "boom" dos condomínios informais.

Por fim, as empresas privadas de construção civil no Distrito Federal, agentes que ainda são pouco tratamento nas pesquisas acadêmicas se considerado o tamanho de sua atuação, devendo ser alvo mais insistente de análises, tendo em vista que com o passar dos anos ganham um papel cada vez mais relevante na constituição e evolução no quadro do Distrito Federal.

O ator privado representado pelas empresas da construção civil só aparecem de forma organizada a partir de 1968, podendo, então, ser de fato observada sua ação, de maneira consistente. Neste ano e em 1969 são colocadas à disposição do mercado imobiliário 156 residências, que representaram um montante de investimento de NCR\$ 6.611.971,00 a preços de 1968, ( $\mathrm{R} \$ 23.930 .115,89$ atualizados a 31 de dezembro de 2007) representando $1,5 \%$ do total investido em habitação, segundo a CODEPLAN.

TABELA V. Quantidade de unidades habitacionais produzidas pelos setores público e privado entre 1964 e 1969

\begin{tabular}{llllll}
\hline Ano & Setor Público & \multicolumn{3}{l}{ Setor Privado } & Total/Ano \\
\hline $\mathbf{1 9 6 4 - 6 5}$ & 2.310 & $100,00 \%$ & 0 & $0,00 \%$ & 2.310 \\
$\mathbf{1 9 6 6}$ & 3.410 & $100,00 \%$ & 0 & $0,00 \%$ & 3.410 \\
$\mathbf{1 9 6 7}$ & 1.239 & $100,00 \%$ & 0 & $0,00 \%$ & 1.239 \\
$\mathbf{1 9 6 8}$ & 7.649 & $90,31 \%$ & 821 & $9,69 \%$ & 8.470 \\
$\mathbf{1 9 6 9}$ & 3.799 & $81,61 \%$ & 856 & $18,39 \%$ & 4.655 \\
\hline TOTAL & $\mathbf{1 8 . 4 0 7}$ & $\mathbf{9 1 , 6 5 \%}$ & $\mathbf{1 . 6 7 7}$ & $\mathbf{8 , 3 5 \%}$ & $\mathbf{2 0 . 0 8 4}$ \\
\hline
\end{tabular}

Fonte:CODEPLAN - Anuários Estatíticos do Distrito Federal ano 1970; e CODEPLAN - Diagnóstico do Setor Habitação 1970.

Esses imóveis são apartamentos de padrão construtivo mais elevado, situados no Plano Piloto, com área média de $115,13 \mathrm{~m}^{2}$ e custo médio de NCR $\$ 42.384,00$ a preços de 1968 , ( $R \$ 153.396,62$ - dez/2007), sendo esse, 43\% maior que a média geral registrada no período. 
Ao todo foram ofertadas no mercado imobiliário, entre 1964 e 1969, 20.084 unidades residenciais, $1.802 .853 \mathrm{~m}^{2}$, num total de investimentos de $\mathrm{NCR} \$ 441.431 .945,00$ (preços de 1968), ou $R \$ 1.597 .635 .198,24$ (preços de 31 de dezembro de 2007).

\subsubsection{As cidades satélites e o controle urbano: a questão da habitação}

A ocupação do solo no Distrito Federal é fortemente marcada pela ação de planejamento estatal, sendo, portanto, o agente imobiliário mais importante do processo de formação da estrutura urbana.

É, antes da inauguração da capital, do Plano Piloto de Lúcio Costa, que se faz sentir a ação do Estado na constituição do território candango como agente ordenador, já que em 1958 surge o primeiro loteamento fora do perímetro planejado, Taguatinga.

A decisão de um loteamento fora do plano original, parte de Israel Pinheiro então presidente da NOVACAP, que, segundo Adirson Vasconcelos ${ }^{143}$, não desejava ampliar o acampamento operário denominado de Cidade Livre que, mais tarde, passa a ser a cidade-satélite do Núcleo Bandeirante. Entretanto entendia como necessidade ampliar as áreas para acomodar os novos operários, a população de trabalhadores não absorvida nos acampamentos das construtoras, e a implantação de uma "cidade operária" foi a resposta.

A migração massiva que ocorria em direção à construção da capital era o outro ponto que se demonstrava fora do controle estatal, a qual provocava uma ocupação não-planejada do território. Não eram apenas operários das construtoras que tinham destino certo, os acampamentos operários, que chegavam, efetivamente, mas os brasileiros dos muitos "Brasis". Pode-se dizer que essa migração no interior, para uma nova fronteira do desenvolvimento era resultado do próprio discurso desenvolvimentista de Kubitschek.

Paradoxalmente ao que se poderia imaginar como idéia do desenvolvimento do interior, no qual acaba por incentivar uma migração interna, no caso de Brasília, ressalta-se uma tentativa de contê-la. A chegada ao Distrito Federal não era afinal fácil ou simples, para adentrar essa nova fronteira do desenvolvimento, para chegar aos canteiros de obras, aos acampamentos, era preciso primeiro passar por barreiras migratórias nas estradas, realizadas pela Guarda Especial de Brasília - GEB onde eram feitas as primeiras triagens dos trabalhadores.

\footnotetext{
${ }^{143}$ VASCONCELOS, José Adirson de - As Cidades Satélites de Brasília. Brasília, 1988
} 
A triagem nessas barreiras da GEB ocorria segundo determinações do Instituto Nacional de Imigração e Colonização - INIC e da NOVACAP, que estabeleciam quem poderia continuar a jornada adentro do quadrilátero, e só tinham esse "direito" trabalhadores que possuíssem alguma qualificação profissional. Mesmo assim, muitos foram os que, mesmo não qualificados transpuseram essas barreiras. ${ }^{144}$.

De 1957 a 1959 essas barreiras representavam uma das formas de controle estatal de acesso ao novo Distrito Federal, se tornando absolutamente ineficiente já no último ano. Era fato que essa mesma migração possibilitava a abundância de mão-de-obra, nem sempre especializada e treinada, representando o exército de reserva da construção da metasíntese do plano de metas.

As construtoras e os próprios IAP motivavam e patrocinavam a migração, contando inclusive com "esquemas" de transposição das barreiras da GEB, com motoristas contratados os quais também eram responsáveis por arrebanhar migrantes, geralmente colonos que acabam se transformando, quando bem sucedida a chegada e a posterior contratação, em trabalhadores urbanos.

A viagem à construção era na maior parte das vezes o primeiro momento de qualificação profissional do sujeito candango, ocorrendo a segunda no canteiro e no acampamento das construtoras.

A mão-de-obra não contratada resultante da migração, a qual o próprio presidente da república denominava de os "novos bandeirantes", buscava em geral ocupar áreas próximas aos acampamentos das construtoras, como estratégia. Mas eram violentamente retirados pela Guarda Especial de Brasília - GEB ${ }^{145}$ e pela Guarda Rural - GRN, as quais tinham

144 Conta-se de expedientes desde propinas a atalhos pelo território, até falsificação de documentação de trabalhadores, ou quando já previamente instruídos por colegas que já faziam parte da construção da nova capital, declaravam especialidades necessárias a construção. Inicialmente comandada pelo coronel reformado da PM do estado do Rio de Janeiro, Antônio Muzzi Alves, o "Coronel Muzza" como ficou conhecido, a GEB foi iniciativa da Divisão de Segurança Púbica da NOVACAP, criada em 20 de fevereiro de 1957, destinada ao controle e segurança de materiais pesados destinados a construção da Nova Capital. Ver em T TEIXEIRA, Hermes Aquino. No tempo da GEB (1956-1960), trabalho e Violência na construção de Brasília: Hermes Teixeira Brasília: Thesaurus, Brasília, 1996.

${ }^{145}$ Quanto a ação da Guarda Especial de Brasília pode-se saber um pouco mais pelas declarações no filme de Wladimir Carvalho, Conterrâneos Velhos de Guerra, no documentário, Brasília segundo Feldman, e na publicação de TEIXEIRA, Hermes Aquino. No tempo da GEB (1956-1960), trabalho e 
como determinação não tolerar as ocupações do novo território da capital que não fossem as planejadas ou autorizadas pelo Estado.

Essa tensão entre os migrantes, os operários, a Guarda Especial de Brasília e a Guarda Rural da Novacap - GRN ${ }^{146}$ provocou o que poderíamos identificar de a primeira estratégia de resistência de "invasões" no Distrito Federal que obteve êxito, ao se observar o caso de Taguatinga. Israel Pinheiro ao decidir projetar a cidade na antiga fazenda de Taguatinga, que seria destinada a atender a 15 mil pessoas, se depara com esse movimento de resistência da "invasão" contígua à Cidade Livre, a qual os moradores estrategicamente nomearam de Vila Sarah Kubitschek.

Essa estratégia motivou a interferência do próprio presidente da república, que, junto com Israel Pinheiro, prioriza o loteamento de Taguatinga. E em apenas seis meses, após a decisão de se criar a primeira cidade-satélite, a NOVACAP estava transferindo, não só parte dos operários, mas também os "invasores". A localização de Taguatinga visava atender a uma visão de execução da obra da capital ao concentrar os trabalhadores, pois ela era próxima ao maior núcleo operário, Cidade Livre, e a outros acampamentos.

Outras "invasões" que vinham se formando são transferidas para Taguatinga e, no final do ano de 1958, o loteamento previsto para 15 mil habitantes já abrigava 10 mil, tornando-se também ponto de chegada dos "novos bandeirantes", que vinham para a nova fronteira.

Havia também considerações técnicas quanto à escolha do local da primeira cidade satélite, a qual deveria ter garantido, por exemplo, o atendimento de água. Assim, questões técnicas eram observadas na implantação física, contudo, o mais representativo é que essa ação teve êxito devido a uma estratégia política dos "invasores", pois, como inexistia um poder judiciário local, ou mesmo instâncias legais de recurso o que impossibilitava um aparato de defesa dos direitos daqueles que ocupavam tais áreas "invadidas", a maneira com que se

Violência na construção de Brasília: Hermes Teixeira Brasília: Thesaurus, Brasília, 1996

${ }^{146}$ A Guarda Rural tinha a função de proteger as áreas rurais. Assim A GEB policiava o que era considerado urbano, a Cidade Livre e a sede da NOVACAP, enquanto a GRN policiava as áreas nãourbanas, tendo atribuição de controle da flora e fauna, cerâmicas e granjas da NOVACAP, além dos acampamentos das construtoras. Essa distinção na prática, não era sempre observada. A formação da "corporação" da GEB e da GRN, se dava pela NOVACAP por meio de seleção entre os operários da construção, dos que possuíam porte físico mais avantajado, e eram armados com cacetes e posteriormente uniformes. Aos poucos policiais do estado de Goiás foram sendo incorporados recebendo patentes superiores, antigos cabos se tornam sargentos, por exemplo. 
desenvolveu o processo se aproxima com uma ação de resistência física com boa articulação final.

A própria ação de polícia, pelo aparelho repressor criado pela NOVACAP, carecia de legitimidade, mesmo que de forma provisória, a polícia do estado de Goiás legitimava as ações GEB e GRN. Não se pode ignorar o fato de que um dos diretores na NOVACAP era Bernardo Sayão, vice-governador do estado de Goiás. Então, por meio de Lei estadual n. ${ }^{\circ}$ 2.364 de 09 de dezembro de 1958, é criado o Departamento Regional de Polícia de Brasília - DRPB, uma maneira encontrada para dar legalidade às atividades da GEB e GRN, sendo então incorporadas à polícia de Goiás. A falta de ordenação jurídica da Nova Capital era um fato que provocava a constituição de relações precárias de legitimidade, impossibilitando, por exemplo, a criação de um agrupamento do Departamento Federal de Segurança Pública - DFSP, a forma considerada mais adequada.

Poderia se afirmar, que o processo de ocupação de Taguatinga se torna um modelo de ocupação inicial das cidades satélites, no qual a pressão causada pela "invasão", a ocupação não planejada, e as formas de ação do Estado na construção da capital parecem descasadas, descoladas, causando um processo onde os fatores contingentes influenciam fortemente o resultado diligente pretendido.

Luiz Alberto de Campos Gouvêa afirma que no Distrito Federal a estrutura urbana implantada é "reflexo de uma ação constante de erradicação de favelas e construção de grandes conjuntos habitacionais, localizados longe do centro de empregos e da sede de poder, o Plano Piloto." ${ }^{147}$

Uma perspectiva de análise que encontra referenciais na discussão do que foi considerado como um modelo centro periferia, uma discussão muito diligente sobre o tema pode ser encontrada em Flávio Villaça, no Espaço Intra-Urbano.

Gouvêa ainda seguindo essa linha de raciocínio coloca:

"De fato, no DF o Poder Público sendo detentor do monopólio das terras e tendo exclusividade das ações de planejamento, teria melhores condições para implementar uma ação de interesse social na área da habitação, todavia, contraditoriamente, empregou estes mecanismos para controlar e segregar a população,"148

\footnotetext{
${ }^{147}$ GOUVÊA, Luiz Alberto de Campos - dissertação de mestrado: Brasília: A capital da segregação e do controle social / uma avaliação da ação governamental na área de habitação - Brasília/1988

${ }^{148}$ GOUVÊA, 1988 pg 2
} 
Atualmente é claro que nunca existiu o monopólio de terras por parte do Estado no DF, e mesmo Gouvêa admite isso ao tratar dos pormenores de seu trabalho, entretanto, a situação durante muito tempo foi pouco conhecida por diversos pesquisadores e até mesmo por uma grande quantidade de agentes governamentais, que reproduziam o discurso instituído das terras públicas da capital, que dava como certo que o rito da desapropriação integral das terras do DF tinha encontrado seu fim.

Esse mito serviu para criar um consenso no habitante de Brasília, determinado conjunto de valores quanto à apropriação dos espaços da cidade. Um deles é o que estabelece a idéia de que aqueles que se apropriam, tomam posse do espaço não ocupado de maneira à degradá-lo ${ }^{149}$, ou seja, se utilizando de formas precárias de infra-estrutura, abaixo da mínima tecnicamente aconselhável ou desejável, na intenção de estabelecer condições de vida, são "invasores" e não "favelados", pois inexiste essa última codificação na linguagem do morador da capital da república.

Esse vocábulo põe em evidência uma particularidade, que aqueles que se encontram excluídos, ou considerados excluídos do processo sócio-econômico e que tomam a posse da terra numa estratégia de sobrevivência, em Brasília são apontados como seres estranhos, exógenos à sociedade, e, por isso, não reconhecidos nem mesmo como indivíduo marginalizado. Portanto, são externos, não fazem parte do mundo compreendido da sociedade local tendo adentrado o lócus dessa sociedade sem permissão ou consentimento, são assim invasores.

Quando afirmado, acima, que são considerados excluídos do processo sócio-econômico, nada mais é que uma maneira de esconder o mais importante, pois, em verdade, estão absolutamente inseridos na economia brasileira. Esses sujeitos são resultado desta realidade e contribuem para que ela se reproduza, garantido a eterna forma de rebaixamento de salário, como podemos observar nas leituras de Francisco de Oliveira em Crítica à Razão Dualista e em o Ornitorrinco.

Contudo, quanto à posse, quando essa resulta da apropriação de espaço feita por sujeitos da sociedade brasiliense (os não-excluídos), ou seja, indivíduos aceitos para incorporar essa sociedade devido a diversas características sociais, seguindo as normas de conduta

\footnotetext{
149 "Um dos estratagemas mais utilizados, pela ideologia é a naturalização dos problemas sociais. As idéias dominantes procuram atribuir à natureza - e não aos homens - as causas dos problemas sociais. Assim a burguesia se isenta de culpa pela falta de solução desses problemas." VILLAÇA, Flávio. Espaço Intra-urbano no Brasil. São Paulo: Studio Nobel: FAPES: Lincoln Institute, 2001 p.299.
} 
geral e pertencentes a algum grupo legitimado, não são por sua vez considerados invasores, não invadem, mas sim ocupam o espaço de forma irregular.

É dada a ele uma codificação diferenciada, mesmo que não exista dentro da norma legal a possibilidade de regularização dessa ocupação, ele dificilmente é identificado ou recebe o rótulo de invasor e, quando assim é interpelado, não se reconhece como tal, de forma a manter sua sujeição à irregularidade e não a ilegalidade. Mas, como não há interpelação de sua ilegalidade, já que esse código é restrito a um tipo considerado exógeno reconhecido, dificilmente é sujeito ilegal e sim irregular.

Uma forma direta de perceber esse raciocínio, e para não demonstrar quanto à forma ideológica de tratamento quanto aos diferentes sujeitos, cita-se o conceito destacado de um trecho de documento oficial

“(...) O termo "invasão" será utilizado para caracterizar um conjunto de moradias subnormais, quase sempre fora dos padrões urbanísticos estabelecidos pelo poder público, que se instala de modo irregular em áreas de propriedade pública ou privada, com carência de infra-estrutura, habitado, sobretudo, por populações de baixa renda, com rendimentos entre 0 a 3 SM."150

O que na verdade reforça, a dificuldade de análise quanto à aparente ineficiência em atacar problemas relacionados com o planejamento urbano de áreas ocupadas, já que há "invasores" os quais devem ser removidos para outras áreas, mesmo que seja admitida que realize a posse de "modo irregular"; e existem os "ocupantes irregulares", que devem ser tratados como potenciais ocupantes legais de áreas. Mas a frente, ao tratar dos parcelamentos por particulares retorna-se a essa discussão.

Retornando ao ponto sobre Taguatinga, é possível verificar que esse loteamento surge conjuntamente com os trâmites de desapropriação da área pelo governo de Goiás, o que pode também ter influído, mas não definido, a escolha da localização da primeira cidadesatélite.

O início com a criação de satélites é um fato não imaginado no planejamento estatal inicial,

150 GDF/SIO Secretaria de Estado de Infra-Estrutura e Obras. Diagnóstico da Situação Atual do Saneamento e Recursos Hídricos do Distrito Federal. Produto 1 - Programa Brasília Sustentável. Brasília, setembro de 2003, pág. 67; ver também GDF/SEDUH Secretaria de Estado de Desenvolvimento Urbano e Habitação. Estudo das Invasões de Baixa Renda no Distrito Federal relatório 2 - o processo de formação de invasões de baixa renda no distrito federal, outubro de 2004 , pág.8. (grifo do autor) 
uma vez que experiências anteriores, como Goiânia (1933) e Belo Horizonte (1897), não demonstravam que o fator migração fosse uma questão que se colocaria com tamanha importância e rapidez. O aumento da população nessas capitais ocorreu com muito menor velocidade em um tempo mais dilatado lembra Benício Schmidt ${ }^{151}$, Belo Horizonte, por exemplo, só consegue se consolidar na década de 30.

Núcleos urbanos implantados nesse período, sem prejuízo das já existentes, Planaltina(1859) e Brazlândia (1933), têm-se Taguatinga (1957), Cruzeiro (1959), que inicialmente se caracteriza mais como um bairro isolado do Plano Piloto, e Candangolândia $^{152}$ (1956), que de assentamento operário vizinho à Cidade Livre, se consolida como uma pequena ocupação urbana e, muitos anos mais tarde, ganha status de cidade satélite. A população desses três núcleos não previstos, inicialmente, mas projetados durante as obras, era composta dos "novos bandeirantes" e de funcionários do Estado que vieram durante a construção da cidade.

A Cidade Livre, hoje, Núcleo Bandeirante ${ }^{153}$, também compõe esse grupo de cidades, sendo a que inicialmente se caracterizava como o centro comercial e social dos trabalhadores de Brasília, podendo com isso ser considerada o centro da capital pré-inauguração, status que rivalizou com Taguatinga por pouco tempo.

O Cruzeiro é a situação diferenciada desse grupo, não fazia parte da proposta inicial de Lúcio Costa, mas, foi imediatamente incorporado em 1958, como um núcleo urbano planejado para habitações econômicas dentro do perímetro do Plano Piloto de Brasília, sendo identificado como Setor de Residências Econômicas Sul.

Da primeira onda de ocupação, Taguatinga, Núcleo Bandeirante e Candangolândia eram os núcleos que apresentavam sinergia mais direta. Outras duas cidades são desse período pré-inauguração, Sobradinho (1959) e Gama (1960).

\footnotetext{
${ }^{151}$ SCHMIDT, Benício Viero. Brasília como centro político in: PAVIANI, Aldo (org). Brasília, ideologia e realidade: Espaço urbano em questão. São Paulo: Projeto, 1981.

152 No início da construção a Candangolândia era conhecida como Lonolândia, devido às característica das ocupações precárias, dos barracos todos executados em lona.

153 O Núcleo Bandeirante é a única cidade-satélite crida por lei federal (lei n. 4.020/61), sendo resultado de um movimento criado pelos moradores do antigo acampamento, destacando-se Jorge Cauhy, que posteriormente se elegeu como deputado distrital, Breno da Silveira que era deputado federal e Joaquim Cândi Garcia um comerciante.
} 
Sobradinho é o resultado da idéia de implantar dentro do quadrilátero do Distrito Federal uma cidade rural, por mais paradoxal que possa parecer numa percepção da atual ocupação do Distrito Federal, ajuda a explicitar um conjunto de variáveis da ocupação urbana. Uma delas é quanto à característica das ocupações na região, hoje, se encontram $28 \%$ de todos os parcelamentos urbanos ditos informais, conhecidos popularmente como condomínios. É nessa região, também, que se verificam as menores quantidades de glebas desapropriadas e maiores situações de conflitos quanto à propriedade fundiária.

A proposta de uma cidade rural já estava posta desde o início, mas não incorporada como ação concreta ou planejada, como afirma Vasconcelos, "durante a construção de Brasília, a partir de 1956, um dos diretores da NOVACAP era o deputado federal e fazendeiro íris Meinberg, que fora presidente da Confederação Nacional de Agricultura. Pelas suas raízes, desejava criar, no novo Distrito Federal, uma cidade tipicamente rural"154.

A idéia do então diretor da NOVACAP, escolhido por Juscelino da lista tríplice da UDN, como forma de garantir o acordo político que criou a NOVACAP e os inícios das obras, motivou, em 1958, um engenheiro do Departamento de Terras e Agricultura da NOVACAP, Ignácio de Lima Ferreira, a apresentar um sítio para a implantação da pretendida cidade rural.

Esse sítio apresentava, segundo o Departamento de Terras e Agricultura - DTA da NOVACAP, condições para atividades agropecuárias, sendo as terras férteis e com boa hidrografia. Se baseava para este parecer no Relatório Belcher ${ }^{155}$, que se tornou praxe do DTA para indicação de glebas para produção, já que os estudos desse relatório eram considerados muito bons, dada a extensão dos dados e o rigor técnico.

É curioso observar que o projeto foi desenvolvido no Departamento de Terras e Agricultura e não no Departamento de Urbanismo e Arquitetura ou Departamento de Viação e Obras da NOVACAP, os quais eram os responsáveis mais diretos pelo processo de implantação e planejamento.

Todavia, há uma interferência de Lúcio Costa que, segundo Vasconcelos, teria "preferido

\footnotetext{
${ }^{154}$ VASCONCELOS - 1988, pg.151

155 Relatório Belcher, foi desenvolvido pela empresa estadunidense, Donald J. Belcher and Associates, em 1948, para subsidiar os estudos da Comissão de Localização e mudança da Nova Capital.
} 
que o planejamento fosse executado por um arquiteto de sua equipe", Paulo Hungria ${ }^{156}$. O que em princípio não desvirtua a idéia original de Íris Meinberg, já que o núcleo urbano de Sobradinho se insere no meio de dois núcleos rurais Sobradinho I e Sobradinho II.

Entretanto, segundo Ernesto Silva ${ }^{157}$, a cidade rural a ser implementada pelo DTA, a partir da visão de Meinberg, acaba por se inserir numa estratégia de abastecimento do Distrito Federal. Foi desenvolvido no âmbito do DTA, um Plano de Abastecimento do Distrito Federal sob a direção de Íris Meinberg e que contava, inicialmente, com uma área de 30.000 hectares, ou seja $300 \mathrm{~km}^{2}$ (5,2\% do território do DF).

O Plano de Abastecimento de Brasília contava em princípio com cinco pólos denominados de Unidade Sócio-Econômica Rural - USER, Supermercados e Centros de Abastecimentos, identificados com a figura a seguir. As USER se caracterizavam como um complexo mercados e depósitos entre outras que "(...) deveriam servir de base ao desenvolvimento das comunidades rurais, oferecendo-lhes, de modo simples e econômico, todos os elementos necessários à satisfação de seu complexo de necessidades." ${ }^{158}$

FIGURA III Centro de Abastecimento de Taguatinga

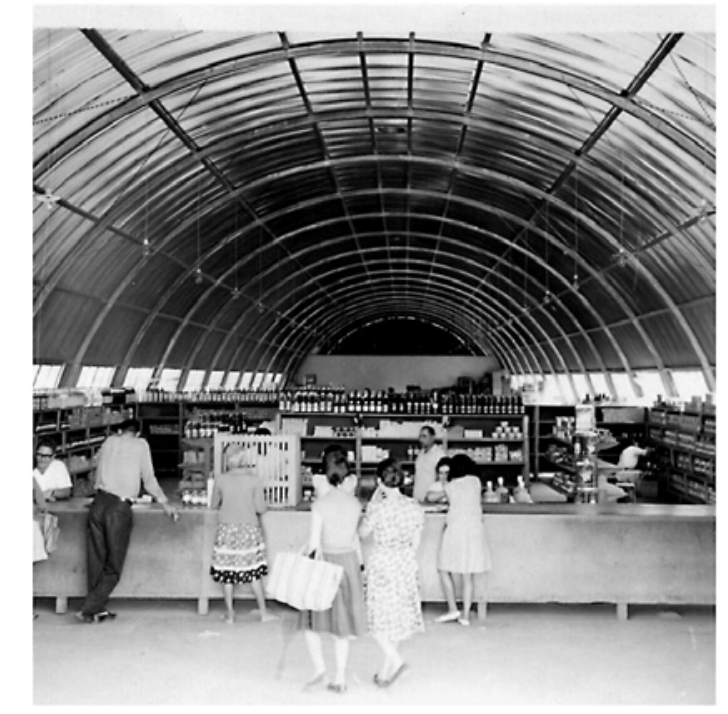

Fonte: Arquivo Público do Distrito Federal;

Autor: não identificado; mar/63

\footnotetext{
${ }^{156}$ Também é autor do Plano Urbanístico do Gama.

157 SILVA, Ernesto. História de Brasília: um sonho, uma esperança, uma realidade - Brasília: Linha gráfica editora, 3 ed, 1997. pg.249 a 253
}

158 SILVA, 1997 op.cit, pg 250 
Essa declaração se aproxima muito do pensamento dos utopistas do século XIX e do discurso de Ebenezer Howard para as cidades-jardim, uma integração entre campo e cidade, em que essa cidade fosse autônoma, auto-suficiente. ${ }^{159}$

Digna também de um panfleto imobiliário sobre a comunidade urbano-rural proposta, tal observação esbarra em uma questão importante, nenhum dos dois povoamentos já existentes no Distrito Federal, Planaltina e Brazlândia, que possuíam características rurais com uma estrutura urbana parcialmente implantada, aparecem mapeados como USER.

Das cinco, duas estão localizadas nas proximidades das cidades satélites de Sobradinho e Gama, criadas com núcleos rurais em seus arredores, uma entre Taguatinga e o Núcleo Bandeirante, outra a $10 \mathrm{~km}$ de Brazlândia e a quinta na saída para o município mineiro de Unaí, e mais, todas essas USER podem ser consideradas como embriões de vários dos parcelamentos informais observados no DF, marcando um cinturão em volta do Plano Piloto, interligados pela Estrada Parque Contorno - EPCT.

Fazendo parte do Plano de Abastecimento estavam os Núcleos-Rurais. As cidades-satélites desse período foram inseridas em meio a eles, estabelecendo uma correlação, nem sempre intencional, entre a criação de núcleos urbano-rurais e a transferência dos ocupantes de "invasões" para as novas satélites, dada a proximidades que uma e outra acabam por estabelecer, já que Taguatinga, Sobradinho e Gama foram inicialmente povoados por processos de "erradicação de invasões", o que põe uma perspectiva especial à questão. Os trabalhadores rurais em busca de melhores condições de vida, que se dirigiram aos canteiros de Brasília, eram novamente colocados, num ambiente rural artificialmente construído.

Esses núcleos tinham características que eram urbanas, mas, inseridos, envoltos, por glebas rurais redivididas em pequenas propriedades, representam um ideário que buscava criar a condição de colônias agrícolas. Poderia se dizer que a pequena cidade do interior era reproduzida pela visão idealizada do administrador público.

A inserção do rural na matriz do planejamento urbano modernista aparece então como um enxerto, como a tentativa de absorver na nova estrutura que se almejava criar, um elemento que parece falso a ela. Se essas condições fossem aplicadas nos povoamentos já existentes, a sensação não seria tão estranha à idéia, mas optou-se por criar esses agrupamentos em novas áreas. Cerca-se o urbano de um rural planejado sob uma nova

\footnotetext{
${ }^{159}$ ver BENEVOLO, Leonardo. História da Arquitetura moderna. São Paulo: editora Perspectiva, 1976 pg 356 a 362. E também RICKERT, ..... - A ... da cidade.
} 
matriz.

Segundo Silva, existia dentro do Plano, a assistência necessária à produção das atividades agropecuárias, convênios com o Ministério da Agricultura, linhas de crédito específicas, para essas glebas que seriam concedidas ${ }^{160}$ a fins de exploração agrícola e pecuária.

Esse primeiro período, de 1957 a 1960, onde são constituídas as novas cidades-satélites de Taguatinga, Gama e Sobradinho, admitindo que mesmo aquelas inauguradas em 1961 são decorrências do primeiro processo de construção comandado pela NOVACAP, representa os primeiros anos de estruturação do espaço da nova capital. É após esse primeiro momento, com a experiência acumulada do processo de construção, que entra em cena um dos atores que irá estabelecer e consolidar toda a ocupação periférica ao Plano Piloto de Brasília.

Sobre a política habitacional que origina e consolida o modelo de ocupação polinucleado, com a criação das cidades satélites, é preponderante ressaltar que, a partir da inauguração com criação da administração do Distrito Federal que temos a constituição de um agente estatal com o perfil semelhante ao encontrado em outras cidades brasileiras, resultado da transferência de atividades e ações da NOVACAP há uma forma administrativa burocratizada do governo local.

É em 1962, com a extinção da Fundação Casa Popular - FCP que produziu em Brasília 1.522 casas no Plano Piloto, e, conseqüente criação da Sociedade Habitações Econômicas de Brasília - SHEB "encarregada de implementar os loteamentos destinados à transferência da população das áreas de ocupação irregular" ${ }^{\prime 161}$, que se marca uma ação mais tecnocrática, baseada na nova burocracia do Distrito Federal.

No período de três anos, entre 1962 e 1964, foram produzidas pífias 98 unidades

\footnotetext{
${ }^{160}$ Não havia transferência ou venda de propriedade, havia concessão de uso por um prazo de 20 anos renováveis. Essa prática prevaleceu durante mitos anos, mesmo após a criação da Fundação Zoobotânica, que incorporou as atividades, e funções do Departamento de Terras e Agricultura - DTA da NOVACAP.

${ }^{161}$ SEDUH (2004) pg 92
} 
residenciais ${ }^{162}$ e entre os fatores que influíram para a baixa produção, está a conturbação política da época e até mesmo a ação do governo de Jânio Quadros que entendia Brasília como uma "aberração". Esse posicionamento quanto a Brasília contribuiu para diminuição da produção da cidade, o que agravou um quadro de inadequação quanto à habitação, já que essa posição política de refrear as obras na capital não teve reflexo na diminuição da migração. Brasília era ponto de convergência rodoviário e destino para um contingente de pessoas expulsas do campo.

Em 1964, com a criação do Banco Nacional de Habitação - BNH, a instituição estatal responsável pela questão de habitação popular, SHEB, sofre sua primeira reestruturação tornando-se a Sociedade de Habitações de Interesse Social - SHIS, visando se integrar ao Sistema Financeiro da Habitação, assumindo o papel de erradicar as habitações consideradas "sub-humanas do Distrito Federal"163, devendo garantir:

— Urbanização inicial mínima para as áreas a serem selecionadas;

- Construção de unidades habitacionais básicas;

- Urbanização das áreas construídas;

- Ajuda técnica e financeira para ampliação e melhoria de unidades residenciais;

- Seleção das famílias destinadas às unidades construídas;

- Cobrança do custo do empreendimento e demais encargos;

- Transferência do domínio das unidades residenciais aos seus ocupantes, após o pagamento do valor de aquisição;

É da atuação da SHIS que se pode ter uma leitura da questão da habitação subvencionada no Distrito Federal, além de contribuir para a leitura da ação estatal no planejamento urbano e na evolução urbana.

Só partir de 1965 que é possível observar sua atuação e, neste ano, com recursos próprios e de beneficiários, oferta 1.674 unidades habitacionais. Em 1966 passa também a utilizar recursos do $\mathrm{BNH}$, em suas formas de provimento. No triênio de 1966 a 1968, a participação dos recursos do $\mathrm{BNH}$, já representa $78 \%$ do total investido na produção de unidades

\footnotetext{
${ }^{162}$ CODEPLAN - Diagnóstico do Setor Habitação do Distrito Federal 1970, pg. 45. Há documentos oficiais, atas de reuniões da diretoria da Sociedade de Habitações Econômicas de Brasília - SHEB até o ano de 1966, quando altera em definitivo sua constituição e estrutura passando a denominação de Sociedade de Habitações de Interesse Social - SHIS.

${ }^{163}$ Idem, pg 45
} 
ofertadas pela SHIS, sendo apenas $2 \%$ dessa mesma produção financiada pelos próprios beneficiários e o restante, ficando a cargo dos recursos da própria SHIS.

A produção inicial da sociedade baseava-se no provimento de casas e apartamentos, estes últimos seguindo na maioria dos casos a tipologia das habitações coletivas de Brasília, ou seja, com pilotis e áreas de circulação e comuns, com depósito e zeladoria. Nesse período, 1966-69, são produzidas 4.842 unidades, nas cidades satélites Guará - 1.100 -; Taguatinga - 1.630 -, Sobradinho - 594 - e Gama - 1.332.

No Plano Piloto são produzidos 324 apartamentos destinados a funcionários públicos de menor poder aquisitivo, com parâmetros diferenciados do estabelecido, a SHIS construiu habitações coletivas de três pavimentos sem pilotis, que ficaram vulgarmente conhecidas como prédios tipo JK. Esse tipo de produção era uma tentativa de baixar custos de produção e viabilizar empreendimentos populares na área nobre, com tipologia diferenciada somente ocorrendo nas quadras duplas (SQDS/N 400) criadas com esse propósito inicial, de ofertar imóveis de menor custo. O modelo dos JK se diferencia basicamente dos demais prédios das quadras duplas exatamente por não possuir pilotis e, por pouca área comum e de circulação.

Suely Franco Neto Gonzales, em seu artigo As formas concretas de segregação residencial em Brasilia ${ }^{164}$, considera o período que compreende 1970 a 1976, o mais importante na evolução do espaço urbano do Distrito Federal, já que compreende uma fase de grande produção relativa e absoluta da Sociedade de Habitações de Interesse Social - SHIS e da consolidação dos setores das Penínsulas Norte e Sul.

Além de ser um momento de grande intensificação da demanda habitacional, pela migração de população de baixa renda a procura de melhores condições e de funcionários dos órgãos públicos. Essa situação de intensa migração e oferta habitacional incompatível com as taxas de crescimento verificadas, produziu em Brasília a situação recorrente em qualquer centro urbano que seja pólo de atração migratória, o que aqui ficou conhecido como "invasão". O que já foi citado nesse trabalho.

Dada à característica de como ocorre tanto o processo de ocupação de áreas pelos indivíduos que não encontram oferta adequada de moradia quanto à ação do Estado, que em Brasília sempre se marcou, desde antes do regime militar, pela remoção e deslocamento desses grupos de indivíduos para áreas consideradas mais aceitáveis a ocupação por esse

${ }^{164}$ GONZALES, Suely Franco Neto - As formas concretas da segregação residencial em Brasília, in: PAVIANI, Aldo (org) - Brasília: ideologia..... 1985, pg 82 
tipo social, o migrante invasor, os conflitos de uma forma ou de outra são sempre esperados.

A violência nos atos de "erradicação de invasões", principalmente em dois períodos identificados 1957 a 1960 e 1985 a 1988, fez com que vários pesquisadores acompanhassem e registrassem esses fatos como modus operandi do processo da política habitacional do Distrito Federal. A GEB, num primeiro momento como vigia do patrimônio da empresa NOVACAP e, posteriormente, as ações do governo de José Aparecido, contribuem para um cenário de investigação acadêmica que tem no controle policial e repressor do Estado sua forma de atuar.

\section{FIGURA IV Remoção de barracos na Vila Planalto}

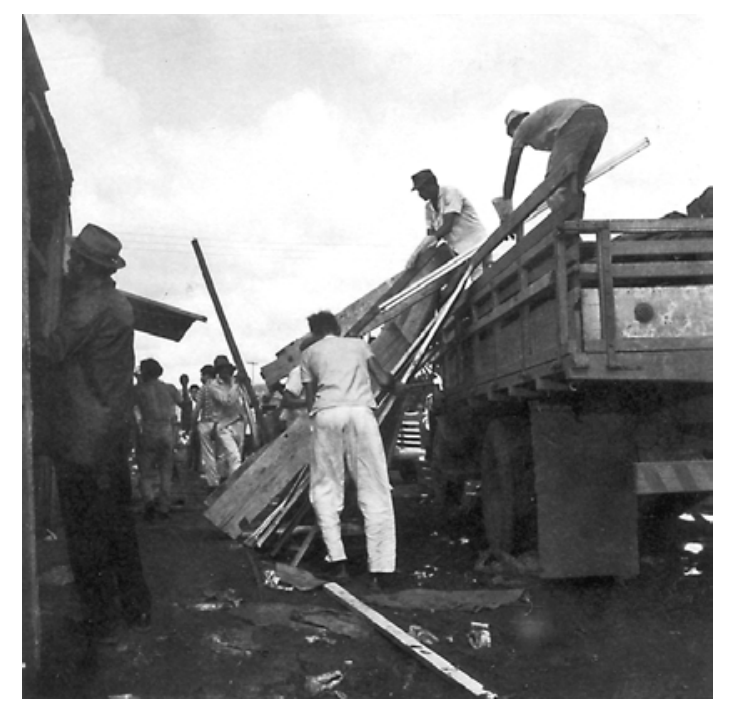

Fonte: Arquivo Público de Distrito Federal - ArPDF;

Autor: Joaquim Firmino 02/Nov/1968

Para se ter uma noção geral dessas ações e como marcaram a sociedade, no governo de José Aparecido registra-se um dos fatos mais assustadores, como afirma Maria da Conceição Vasconcelos Gonçalves.

"A situação era tão grave em relação à violência, durante o governo José Aparecido, que o Comitê pela Dignidade de Brasília, vinculado à Comissão de Justiça e Paz em agosto de 1988, com base na lei que protege os animais número 24/645 de 1934, conseguiu impedir que o Governo do Distrito Federal (GDF) continuasse a sua ação demolidora de destruir barracos, durante 90 dias. ${ }^{, 165}$

165 GONÇALVES, Maria da Conceição Vasconcelos. Favelas Teimosas. Brasília: Thesaurus, 1998. 
Imagina-se o nível de truculência e barbárie que caracterizavam a execução dessas retiradas. Obviamente, o governo recorreu da decisão, conseguindo suspendê-la, mas, consecutivamente o Supremo Tribunal Federal volta a ratificar a liminar, constituindo assim, na primeira vez que o STF legisla sobre um problema de favelas, sendo por isso uma decisão histórica para os movimentos sociais de moradia.

Para entender o cenário de produção habitacional estatal, foi feita uma investigação para estabelecer um panorama. Num quadro geral de produção habitacional executada pela SHEB, posteriormente SHIS e IDHAB, é possível verificar a mudança na ação do governo quanto à política de atendimento habitacional.

TABELA VI. Quantidade de Unidades Habitacionais produzidas pela Sociedade de Habitaçoes de Interesse Social - SHIS, por período de gestão administrativa, segundo tipo, durante o período de 1963 a 2005

\begin{tabular}{|c|c|c|c|c|c|}
\hline Período & Prefeito/Governador & Apart $^{\circ}$ & Casa & Lote & Total \\
\hline $1963-64$ & Ivo Magalhães ${ }^{1}$ & - & 98 & - & 98 \\
\hline $1965-66$ & Plínio Catanhêde & - & 3.970 & - & 3.970 \\
\hline $1967-68$ & Wadjô Gomide & 168 & 2.360 & - & 2.528 \\
\hline $1969-73$ & Hélio Prates & 650 & 16.511 & - & 17.161 \\
\hline $1974-78$ & Elmo Serejo Faria & 1.374 & 22.033 & - & 23.387 \\
\hline $1979-81$ & Aimeé Lamaison & 144 & 15.446 & - & 15.590 \\
\hline $1982-85$ & José Ornelas² & 1.440 & 8.445 & - & 9.895 \\
\hline $1986-87$ & José Aparecido & 690 & 891 & - & 1.581 \\
\hline $1988-90$ & Joaquim Roriz ${ }^{3}$ & 72 & 3.992 & - & 4.064 \\
\hline $1991-94$ & Joaquim Roriz & 72 & 686 & 40.009 & 40.767 \\
\hline $1995-98$ & Cristovam Buarque & - & - & 12.689 & 12.689 \\
\hline 1999-05 & Joaquim Roriz & - & - & 22.632 & 22.632 \\
\hline Total & & 4.590 & 74.382 & 66.785 & 145.817 \\
\hline
\end{tabular}

Fonte: CODEPLAN - Anuários estatísticos do Distrito Federal de 1977 a 2005; SHEB/ SHIS - Relatório Geral e Prestação de Contas Exercício de 1969 a 1989

Notas: Os lotes a que se refere é o lote semi-urbanizado.

${ }^{1}$ No ano de 1964, devido ao golpe, houve uma sucessão de prefeitos: Ivo Magalhães, Ivan de Souza e Plínio Catanhêde

${ }^{2}$ Em 1985, no processo de redemocratização, houve outra sucessão de governadores biônicos: José Ornellas, Ronaldo Costa e José Aparecido 
${ }^{3}$ Em 1988, José Aparecido e Joaquim Roriz, e em 1990 Wanderley Valim assume para que Roriz saia candidato a primeira eleição direta a governo do Distrito Federal

Há algumas considerações quanto à variação na oferta, quanto ao volume e tipo de unidade ofertada, entre elas podemos destacar anos sem qualquer oferta de unidades habitacionais, como no caso de 1967, 1971, 1980 e 1988 nos governos do prefeito biônico Wadjô Gomide, e dos governadores biônicos Hélio Prates, Aimeé Lamaison e José Aparecido/Joaquim Roriz, o que nem sempre significou menores taxas de produção.

Entre 1980 e 1982 a oferta de imóveis pela SHIS foi de apenas 288 unidades habitacionais, devido à política implementada pelo governador biônico Aymeé Lamaison (1979-1981), indicado pelo então Presidente da República General João Batista Figueiredo.

Essa paralisação de obras tinha por trás uma "filosofia" da administração local, que pode ser observada em documentos oficiais da SHIS

"No exercício de 1980 a administração da Empresa esteve condicionada por 2 pontos básicos. De um lado a política de desenvolvimento urbano preconizada pelo Governo do Distrito Federal que sugere maior cuidado na execução de obras habitacionais, particularmente no sentido de evitar a construção de grandes conjuntos residenciais, já que se tem como ponto de referência, que tais obras ensejaram um acréscimo substancial no fluxo migratório para Brasília. O outro ponto refere-se à significativa redução da oferta de recursos financeiros provenientes do Banco Nacional da Habitação, com decorrência da política econômica do país, cujos objetivos de combate a inflação são naturalmente prioritários."166

Toma-se o reflexo pela causa, pois a dada conjuntura econômica e a não adoção de políticas públicas vinculadas à questão agrária são refreada pelo argumento. Ou seja, o incremento populacional é causado, segundo a ideologia administrativa do Governo do Distrito Federal, pela produção de habitação e sua política de oferta aos trabalhadores e não pela própria condição social e econômica, a falta de política de reforma agrária e de regulação das relações de trabalho no campo, por exemplo. Essa passagem marca uma idéia-força dominante no pensamento da sociedade brasiliense, onde a oferta de unidades habitacionais, seja por meio de provimento, ou por loteamento, incita a migração de desvalidos para o território da capital da república.

166 Sociedade de Habitações de Interesse Social - SHIS. Relatório Geral e Prestação de Contas Exercício 1980, mimeo. Brasília, 1981. pg 2 (de 1969 a 1990) 
FIGURA V Casas construídas pela SHIS em Samambaia
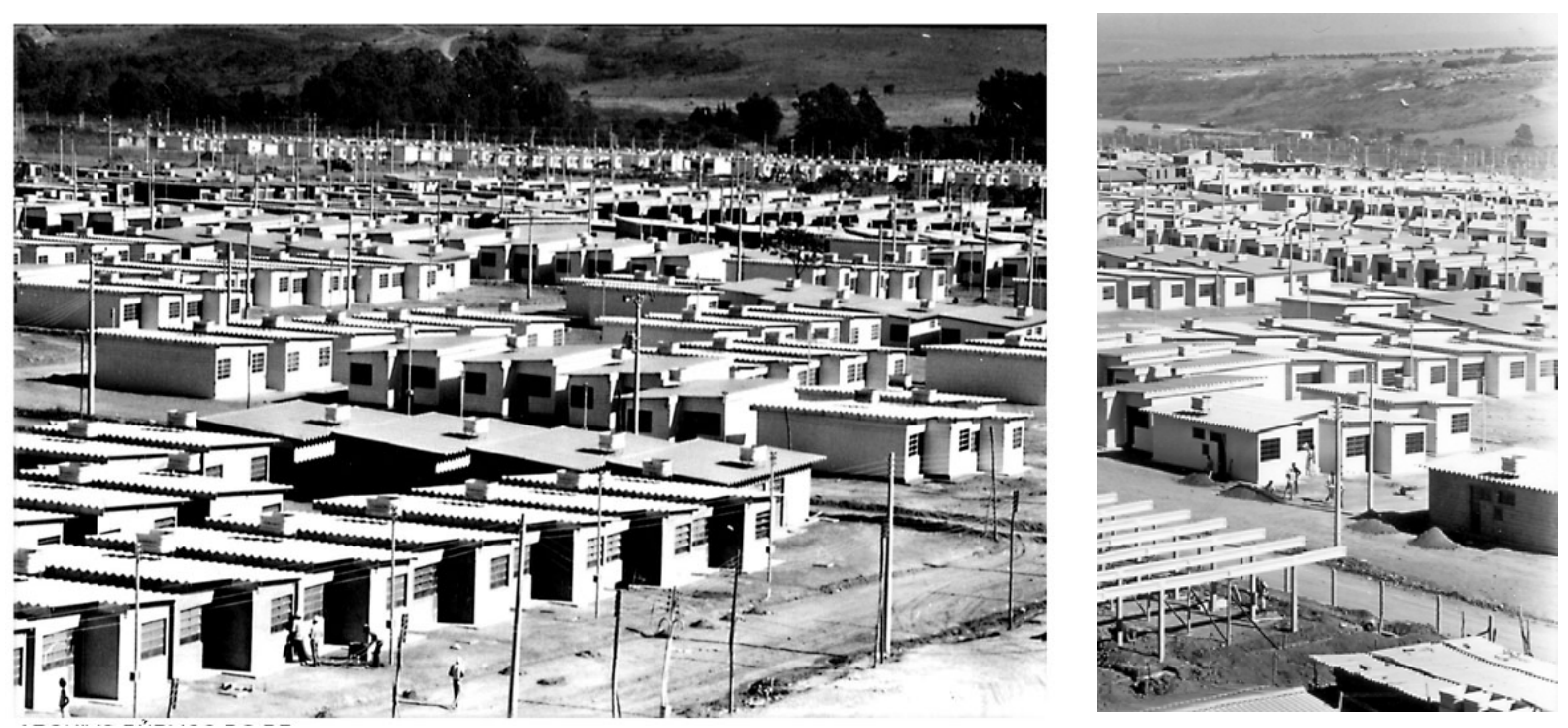

Fonte: Arquivo Público de Distrito Federal - ArPDF;

Autor: Rodolfo Stucket 1988

José de Souza Martins adverte que essa percepção maléfica da migração campo-cidade é uma herança do pensamento das classes dominantes da década de 50 , que vêem nos contingentes sub-remunerados do campo sua forma de realização de poder no interior do país. Numa consciência herdada, portanto, domina a idéia de que a pobreza e seus efeitos desagregadores podem influir na ordem social e, assim, "esconde, na verdade, uma típica preocupação de classe média com a preservação da ordem. Esse é um problema para as classes dominantes, e não para os trabalhadores (por isso, torna-se com freqüência um problema de polícia)."

De 1982 a 1985, assume o Governo do Distrito Federal José Ornellas, que tardiamente implanta o PROMORAR em Brasília sob o nome de Programa de Atendimento Populacional de Emergência - PAPE, executado pelo Grupo Executivo Para Assentamento de Favelas e Invasões - GEPAFI. A política de José Ornellas é considerada uma das mais abrangentes, com forte viés tecnocrático.

A administração desse período se caracteriza por uma busca de oferta habitacional em todos os segmentos sociais, incentivando, por exemplo, a construção dos condomínios fechados da Octogonal, como também, surge o projeto de Águas Claras, destinados ao atendimento da classe média. Existia uma forte influência política para a realização de ações globais, já que o país vivia o processo de abertura política iniciado no governo de

${ }^{167}$ MARTINS, 1997, p. 40 
Figueiredo, e as ações de cunho político começavam a esboçar uma necessidade de atendimento às questões mais abrangentes socialmente.

Mesmo assim, a produção habitacional estatal não era a mesma, os mecanismos de financiamento que se utilizavam dos recursos captados pelo $\mathrm{BNH}$, já estavam prenunciando sua iminente crise, o que pode ser percebido com a decrescente produção de unidades habitacionais.

TABELA VII. Quantidade de Unidades Habitacionais produzidas (casas e apartamentos), e recursos investidos de acordo com a o órgão estatal e gestão administrativa no período de 1966 a 1991. Valores atualizados a 31/12/2007 pelo INCC-FGV (R\$ $1.000,00)$.

\begin{tabular}{|c|c|c|c|c|c|c|}
\hline Período & Prefeito/Governador & $\mathrm{UH}$ & $\mathrm{BNH}$ & SHIS & Outros $^{1}$ & Total \\
\hline 1966 & Plínio Catanhêde & 666 & 67,71 & 0,10 & 0,00 & 67,81 \\
\hline $1967-68$ & Wadjô Gomide & 2.528 & $41.198,13$ & $20.258,34$ & 0,00 & $61.456,47$ \\
\hline $1969-73$ & Hélio Prates & 14.632 & $876.694,44$ & $252.557,05$ & $94.462,41$ & $1.223 .713,90$ \\
\hline $1974-78$ & Elmo Serejo Faria & 21.199 & $399.766,76$ & $186.657,34$ & 0,00 & $780.724,40$ \\
\hline 1979-81 & Aimeé Lamaison & 15.375 & $219.007,96$ & 0,00 & 0,00 & $219.007,96$ \\
\hline $1982-85$ & José Ornelas ${ }^{2}$ & 1.545 & $58.463,91$ & $3.410,96$ & 6,64 & $61.881,51$ \\
\hline $1986-87$ & José Aparecido & 234 & $6.334,55$ & $17.519,63$ & 0,00 & $23.854,18$ \\
\hline $1988-91$ & Joaquim Roriz ${ }^{3}$ & 0 & 339,73 & 0,00 & $16.192,80$ & $16.532,53$ \\
\hline Total & & 56.179 & $1.601 .873,19$ & $480.403,42$ & $110.661,85$ & $2.387 .238,76$ \\
\hline \multicolumn{6}{|c|}{ Fonte: CODEPLAN - Anuários estatísticos do Distrito Federal de 1977 a 2005; SHEB/ SHIS - Relatório Geral e } & Prestação de Contas Exercício de 1969 a 1989 \\
\hline \multicolumn{7}{|c|}{$\begin{array}{l}\text { Notas: UH - Unidades Habitacionais, se referem a investimentos em casas e apartamentos em sua grande } \\
\text { maioria nas cidades-satélites }\end{array}$} \\
\hline \multicolumn{7}{|c|}{${ }^{1}$ Esses outros agentes se referem ao governo local, ao Banco Regional de Brasília (BRB) e Caixa } \\
\hline \multicolumn{7}{|c|}{ Econômica Federal (CEF). } \\
\hline \multicolumn{7}{|c|}{ ² Em 1985, no processo de redemocratização, houve outra sucessão de governadores biônicos: José } \\
\hline \multicolumn{7}{|c|}{ Ornellas, Ronaldo Costa e José Aparecido } \\
\hline $\begin{array}{l}{ }^{3} \mathrm{El} \\
\mathrm{can}\end{array}$ & $\begin{array}{l}\text { 1988, José Aparecido e } \mathrm{J} \\
\text { dato na primeira eleição } \mathrm{d}\end{array}$ & quim Roriz & em 1990 W & ey Valin & Ime nara g & ia \\
\hline
\end{tabular}

Para se ter uma noção dos investimentos do BNH no DF através da produção da SHIS, no período de 1966 a 1991, das 76.453 unidades habitacionais produzidas, 56.719 utilizaram recursos do Banco, em maior ou menor grau, sendo este responsável por nada menos que $67,56 \%$ do total de recursos investidos em habitações pela SHIS, que investiu $20,26 \%$ com recursos próprios e o restante, menos de $2,3 \%$ de recursos de diversas fontes, como governo local e agentes financeiros. 
No governo Hélio Prates é criada a cidade-satélite de Ceilândia com grande impacto nos investimentos desse período, o que pode ser notado no alto custo observado na relação entre custo e quantidade de unidades habitacionais, já que incluem investimentos em infraestrutura da área.

Ceilândia, criada em 1971 para receber as populações oriundas das remoções da Campanha para Erradicação de Invasões - CEl, era inicialmente um setor habitacional em Taguatinga que se amplia a medida que a campanha toma corpo. Apesar da vinculação da proximidade com a primeira cidade-satélite sua malha urbana nãos é continua, e nem mesmo segue o mesmo desenho, é uma ampliação não integrada devido a um córrego que funcionou como uma faixa de "amortecimento" entre os dois núcleos. O nome Ceilândia surge posteriormente e era vista como a segregação da segregação.

No governo José Aparecido entre 1985 a 1988, há uma retomada da ideologia de apartação social, do controle social por meio de duas políticas altamente divulgadas, o "Retorno com Dignidade", que incentivava o retorno dos migrantes a sua terra natal, mais precisamente colocava esse individuo, por vezes recém chegado à cidade, sem destino ou endereço em um ônibus de regresso à sua cidade origem, e o "Entorno com dignidade" que incentivou a construção de conjuntos habitacionais nas cidades do entorno do Distrito Federal, bem como aqueceu o mercado de parcelamento dos municípios goianos do entorno. Essas políticas de Aparecido são facilitadas pela própria estrutura administrativa do Distrito Federal que ainda era federalizada, e assim recursos para atendimento a elas não necessitavam ser necessariamente gastos no território do Distrito Federal o que facilitava a dotação de recursos para o entorno.

A Faixa Sanitária, como forma de preservação e controle ao adensamento populacional, no Governo de José Aparecido, é ampliada para além da Bacia do Paranoá e não se apresentava como uma questão de gestão dos recursos hídricos e capacidade das infraestruturas, o discurso tomava forma na preservação do Patrimônio Modernista de Brasília que não podia ser deturpado. Os malefícios de um crescimento desordenado deviam ser combatidos.

Os esforços iniciados neste governo culminaram na declaração da UNESCO de Brasília como Patrimônio Cultural da Humanidade, instituindo assim mais um mecanismo de controle do governo do Distrito Federal.

Outro fator adjacente no governo José Aparecido que tem impacto posterior é a contínua e gradativa desvinculação do Governo do Distrito Federal em relação ao Governo Federal. 
Esse fato pode ser notado desde 1980 quando as transferências de capital e recursos federais ao governo local sofrem alterações consideráveis. ${ }^{168}$

Na gestão seguinte, após o tumultuado ano de 1985, quando José Aparecido dá lugar a Ronaldo Costa Couto, governador indicado no período de transição e que fica poucos meses no cargo, dando lugar a Joaquim Roriz que, começa a gestação de uma nova maneira de encarar o atendimento habitacional.

Nos anos seguintes a 1985, de 1986 a 1991, a atuação da SHIS como produtora de habitação começa a mudar e a execução de unidades habitacionais em seis anos é de pouco mais de 5300 unidades, dando lugar em 1992 à política de assentamentos de populações de baixa renda em grandes áreas desprovidas de infra-estrutura, por meio da distribuição de lotes semi-urbanizados.

Os assentamentos de lotes semi-urbanizados contam com uma precaríssima infra-estrutura inicial. É garantida apenas a demarcação dos lotes, arruamento, executado apenas em cascalho, ponto de luz que deveria ser requisitado pelo futuro morador, o abastecimento de água era feito de duas formas: caminhão pipa da CAESB, ou, quando muito, em chafariz público instalado por essa companhia que atendia a um conjunto de quadras. Recanto das Emas, Riacho Fundo II, Santa Maria e parte de Samambaia são resultado dessa política.

Quanto à questão fundiária, ou de propriedade imobiliária, não há transferência do poder público a esses ocupantes, os quais possuem apenas um termo precário de posse, de permissão de uso. Essa condição de ocupante é dada pela impossibilidade do registro imobiliário desses parcelamentos já que feriam a lei $n .^{\circ} 6.776 / 79$, por não cumprirem os padrões mínimos de urbanização.

Além disso, muitos desses assentamentos se encontram em terras de propriedade contestada judicialmente por antigos proprietários, ou mesmo pela TERRACAP. Como marcado anteriormente, cidades como Paranoá encontram-se marcadamente, inclusive em mapas da companhia imobiliária, como sendo de propriedade privada, somando-se a isso, em outros casos, o imbróglio das licenças ambientais de instalação e operação que nem mesmo chegam a ser liberadas, dificultando ainda mais o processo de legalização do

\footnotetext{
${ }^{168}$ É a partir de 1980 que o Distrito Federal passa a receber regularmente verbas específicas, por meio das transferências do Fundo de Participação dos Estados, ficando mais independente do orçamento da União, mesmo assim, continuam a haver transferências especiais da União, com aval do Congresso Nacional, do Senado Federal, mais precisamente. Essa diferenciação é possível de ser observada nos Anuários Estatísticos do Distrito Federal produzidos pela CODEPLAN.
} 
assentamento.

Mas, neste ato marca-se o discurso, o antigo invasor passa a ser ocupante irregular e, portanto, aceito. Colocado a distância da área nobre, no limite externo marcado pela Faixa Sanitária, na maioria das vezes em assentamentos executados pelo Estado com mínima ou nenhuma condição de habitabilidade, sem infra-estrutura de saneamento e chamado a cumprir seu dever cívico de cidadão.

Como visto, esse sujeito não é um excluído economicamente e nem politicamente, a partir da segunda metade da década de 80 e início de 90, pois é nesse momento nacional que volta a se torna cidadão apto.

É impressionante a precarização, a redução das condições de moradia que levam muitos a marcar a política habitacional do governo em 1991, como política clientelista com o claro viés de criação de contingentes de eleitores comprometidos, devedores de favores. O lote seria um favor, não um direito. O clientelismo era facilmente identificado com a política que começa a se delinear num período pré-eleitoral com sua materialidade em 1992.

Foi usada inclusive a mesma forma discursiva de que a produção habitacional de grandes assentamentos eram atratoras de migração desqualificada e despreparada, como é o histórico dessa migração desde a construção. Contudo, nesse momento, possuía outro valor a oferecer que não só a força de trabalho, mas algo de outro valor como barganha, o voto.

De uma hora para outra os migrantes desqualificados que compuseram os contingentes populacionais erradicados de invasões, se tornaram na mais preciosa força sendo determinante para o processo político-eleitoral.

As críticas a esse processo são inúmeras, contudo, há de se marcar um papel mais universal dessa política, pois, até então, parte considerável da produção habitacional da SHIS, destinava-se ao atendimento do grupo formado pelos funcionários públicos, tanto do governo local como federal. Assim, mesmo que tenha existido política de investimentos para atendimento a população de menor renda, identificado como não-servidora pública, não foi capaz de atender a uma demanda reprimida.

A ação de "distribuição de lotes semi-urbanizados" vem como uma solução invertida, como se criasse em laboratório, uma ocupação precarizada para posteriormente urbanizar. Ainda que respeitando um projeto urbanístico, os fatores de contingência, não estão no planejamento urbano e sim na fórmula da política adotada.

Nessa fórmula a questão fundiária se tornou um dos grandes problemas a ser enfrentado, em separada ou em conjunto com a questão ambiental, que durante muito tempo serviu e 
ainda serve como forma de controle urbano de ocupações em áreas especiais.

Para Martins:

"A nova desigualdade separa materialmente, mas unifica ideologicamente. No entanto, a nova desigualdade se caracteriza basicamente por criar uma sociedade dupla, como se fossem dois mundos que se excluem reciprocamente, embora parecidos na forma: em ambos podem ser encontradas as mesmas coisas, aparentemente as mesmas mercadorias, as mesmas idéias individualistas, a mesma competição. Mas, as oportunidades são completamente desiguais. A nova desigualdade resulta do encerramento de uma longa era de possibilidades de ascensão social, que foi característica do capitalismo até há poucos anos. Apesar disso, o imaginário que cimenta essa ruptura é um imaginário único, mercantilizado, enganador e manipulável."169

Quanto ao discurso que vincula o crescimento da periferia, a política de distribuição de lotes, com uma política clientelista-eleitoreira, alguns dados recentes apontam para o esclarecimento da questão.

TABELA VIII. População Urbana, segundo o motivo da última mudança de residência para a atual Região Administrativa - Distrito Federal - 2004.

\begin{tabular}{lll}
\hline Descrição dos Motivos & População & Percentual \\
\hline Melhorar de Vida & 188.940 & $13,4 \%$ \\
\hline Estudo e/ou Escola & 19.356 & $1,4 \%$ \\
\hline Trabalho & 144.121 & $10,2 \%$ \\
\hline Moradia & 247.288 & $17,5 \%$ \\
\hline Adquirir lote & 57.584 & $4,1 \%$ \\
\hline Acompanhar parentes & 655.728 & $46,5 \%$ \\
\hline Saúde & 7.564 & $0,5 \%$ \\
\hline Outros & 90.448 & $6,4 \%$ \\
\hline Subtotal & 1.411 .029 & $100 \%$ \\
\hline Nunca Mudou & 685.505 & - \\
\hline Total & 2.096 .534 & - \\
\hline Fon & & \\
\hline
\end{tabular}

Fonte: SEPLAN/CODEPLAN - Pesquisa Distrital por Amostra de Domicílios - PDAD

Obviamente algumas ponderações devem ser feitas com relação aos resultados, uma delas é quanto à periodicidade do levantamento, pois não capta algumas mudanças significativas

${ }^{169}$ MARTINS, 1997 p.21 
como o motivo da vinda para o Distrito Federal, já que o item "Adquirir lotes" é a inovação da pesquisa, não sendo encontrado em nenhum outro levantamento que a pesquisa para esse trabalho teve acesso.

O que se consideraria adequado, para a uma mensuração mais precisa seria estar expresso o motivo de migração para o Distrito Federal, e não apenas para a Região Administrativa em que se mora atualmente, já que esse dado é ocultado pela mobilidade interna no aglomerado urbano do território

.E, mesmo considerada essa observação, tendo em vista que a mobilidade para aquisição de lotes semi-urbanizados tende a ocorrer nas populações de baixa-renda, o discurso que se atém à distribuição de lotes como catalisador de uma migração de excluídos, encontra dificuldade em se concretizar como uma crítica à ação política.

Outro dado importante, que dificulta ainda mais essa crítica pôde ser coletado de pesquisa sobre o processo eleitoral de 1998, no qual os candidatos ao Governo do Distrito Federal que polarizaram a disputa eram Cristovam Buarque (PT - governador entre 1995 e 1998) e Joaquim Roriz (PMDB - governador entre 1988 a 1994), sendo este último responsável pela implementação maciça da distribuição de lotes semi-urbanizados.

Para perceber como essa discussão é gestada dentro do senso comum do cidadão brasiliense, já que a pesquisa de Gláucio Ary Dillon Soares ${ }^{170}$ se faz a partir da arena eleitoral, cita-se um trecho do raciocínio desse pesquisador na integra:

"Roriz é popular devido à distribuição de lotes e à sua imagem de 'próximo ao povo'. Significa isto que teria vitória garantida nas eleições, caso o quadro pré-eleitoral se mantivesse? Também não. Objetivamente, Roriz distribuiu mais lotes que qualquer governador. Isto the granjeou apoio entre os que receberam lotes, seus familiares e amigos. Provocou, talvez, simpatias entre os que aspiravam receber um lote. Inicialmente, a política de distribuição de lotes era o sonho de qualquer político: afastava 'invasores' considerados incômodos e/ou perigosos pelos residentes de áreas de classe alta, média ou trabalhadora estabelecida e os transferia para áreas distantes, dando-lhes lotes. Agradou a todos. Posteriormente, porém, esta política passou a ser questionada, tendo em vista a criminalidade violenta que caracteriza estas áreas e a alta taxa de crescimento demográfico de vários destes assentamentos. Setenta e quatro porcento

170 SOARES, Gláucio Ary Dillon. Em Busca da Racionalidade Perdida: alguns determinantes do voto no Distrito Federal. Revista Brasileira de Ciências Sociais. vol.15 n.43 São Paulo. http://www.scielo.br/scielo.php?pid=S0102-69092000000200001\&script=sci_arttext. Acesso: 20 de dezembro de 2007. 
(sic) dos entrevistados concordavam que a distribuição de lotes feita por Roriz atraiu imigrantes. Eleitoralmente, Roriz arrazou (sic) entre a minoria que achava que os assentamentos não atraíram migrantes internos: $60 \%$, em claro contraste com $31 \%$ entre os que acreditavam que atraíram. Os demais pré-candidatos cresceram entre os que acreditavam que a distribuição de lotes atraiu imigrantes: Cristovam, de $11 \%$ para $24 \%$; Arruda, de $6 \%$ para $14 \%$, e Augusto Carvalho, de 1\% para 4\%. A opinião pública a respeito da criação de novos assentamentos também se modificou com o tempo. Se, há poucos anos, a população era avassaladoramente favorável à medida, na época da coleta de dados para esta pesquisa a proposta era apoiada por somente $42 \%$ dos entrevistados. Entre os que apoiavam a criação de novos assentamentos, Roriz recebia $45 \%$ das preferências; entre os que não apoiavam, a percentagem caía para $23 \%$. Os demais pré-candidatos, ao contrário, subiram: Cristovam, de 19\% para 27\%; Arruda, de 9\% para $16 \%$ e Augusto Carvalho, de $2 \%$ para 5\%. A política de distribuição de lotes foi, assim, um dos temas centrais da campanha eleitoral, devido à sua alta correlação com a intenção de voto."

A aprovação ou não de Roriz, que venceu as eleições, não se procedeu por resultado única e exclusivamente de uma política dita "clientelista" de distribuição de lotes segundo as conclusões de Soares, o que coloca a questão de uma escolha racional ${ }^{171} \mathrm{em}$ prova. Soares acredita que um conjunto de fatores e mesmo de programas que a ele os eleitores vinculavam foi a principal razão.

Contrariamente ao que possa se acreditar não foi apenas o processo eleitoral que determinou a continuação do programa de distribuição de lotes semi-urbanizados, Cristovam Buarque tido como uma figura contrastante a Roriz, e vinculado a correntes consideradas mais socialistas, também deu continuidade a distribuição de lotes semi-urbanizados, mesmo que em menor escala, que o período anterior de Roriz (1989 - 1994). O próprio governador Roriz diminui a produção de lotes no período de 1999 a 2005, se aproximando da média de Cristovam, 3000 lotes/ano.

\footnotetext{
${ }^{171} \mathrm{~A}$ escolha racional aqui referida é relacionada ao campo de investigação das ciências políticas que tem como princípios de análise a teoria democrática. Autores como Robert Dahl, atribuem a escolha de um candidato num processo eleitoral vinculada sempre a uma racionalidade do eleitor, que por meio de mediações e acesso a informações disponíveis tende a fazer opções mais próximas a sua agenda pessoal, a seus interesses. Nem todo candidato responde a $100 \%$ da agenda individual de cada eleitor, mas aquele que atende a número considerável de pontos e garante prioridade a outros pode ser identificado como o candidato escolhido. Não intenção é desse trabalho entender a teoria democrática da escolha racional, ou mesmo a escolha de um candidato em detrimento a outro.
} 
Para Gouvêa, a condição impar do DF, onde o Estado detém a propriedade de grandes áreas, exclusividade no planejamento e parcelamento do solo e "facilidades de conseguir financiamentos, mecanismos estes 'sonhados' por todo administrador de cidade do País", não contribuíram para uma oferta de habitação, "a ação governamental em Brasília se pautou pela não oferta de habitações e/ou por remover as favelas para as distantes cidades satélites, utilizando todo este instrumental, contraditoriamente, para agravar o problema habitacional e social da cidade"172

Em seu entender nunca houve no País uma instituição voltada para sanar os problemas da habitação mas sim organismo que se destinavam à produção de moradias, que tinham a finalidade de controle político e de exploração econômica da maioria da população.

Esse corpo material do Estado prescinde de uma forma de atuação, segundo ele, seria constantemente abastecido por políticas temporárias de incentivos, o que não pode ser considerada como uma política para a área. Essa posição dá peso maior ao aparelho, à instituição governamental que irá praticar a ação, do que numa formação de políticas de acesso a moradia.

\subsubsection{Os parcelamentos do solo por particulares}

Há uma crença difundida no pensamento público, da administração pública no todo, de que a ação de empreendedores imobiliários, especuladores e grileiros são resultado de uma demanda por habitação e que "principalmente nas décadas de 80 e 90, em função da crescente demanda habitacional, alimentada não só pela migração, como, também, pelas altas taxas de fecundidade experimentada em anos anteriores" ${ }^{\text {"173 }}$, criaram um cenário de difícil resolução.

Ora, se existem registros que o processo de parcelamento do solo no Distrito Federal, por iniciativa privada, não pública, ocorre desde o início dos trabalhos de desapropriação das terras do quadrilátero, e mesmo anterior a ele, como afirma Altamiro de Moura Pacheco em seus relatórios como presidente da Comissão de Cooperação para a Mudança da Nova Capital, esse entendimento merece atenção quanto a sua análise conclusiva.

\footnotetext{
${ }^{172}$ GOUVÊA, 1988 pg. 22

${ }^{173}$ GDF/SEDUH - Secretaria de Estado de Desenvolvimento Urbano e Habitação. O Modelo de A Gestão - (2004) pág. 92.
} 
É em documento recente redigido pela própria Secretaria de Estado de Desenvolvimento Urbano e Habitação - SEDUH, que visava subsidiar os estudos para a revisão do Plano Diretor de Ordenamento Territorial do Distrito Federal, que se admite que a ação de parcelamento irregular do solo por agentes privados tem seu início em 1975, com a identificação do primeiro loteamento. Há também registro importante quanto ao processo de urbanização e ocupação urbana do território do Distrito Federal.

"Muitos problemas de ordenamento territorial hoje enfrentados no Distrito Federal vinculam-se diretamente às questões fundiárias hoje, sobretudo em função da não conclusão do processo de desapropriação das terras, da precariedade de títulos de domínio e da imprecisão na demarcação das terras públicas e particulares.

A indefinição da titularidade da propriedade da terra, a carência de moradia, o monopólio do Estado no parcelamento e comercialização das terras, a falta de uma política de financiamento para a habitação, sobretudo para classe média, e a especulação imobiliária, entre outros fatores, provocaram no Distrito Federal o surgimento de numerosos parcelamentos ilegais do solo, em áreas públicas e privadas." ${ }^{174}$

Esse documento técnico aparece como sendo revelador de uma nova postura, ao admitir e incorporar em seu conteúdo discursivo, as dificuldades inerentes do regime fundiário do Distrito Federal, que tem naturezas jurídicas diversas, não sendo apenas uma propriedade única do Estado, mas se aproximando da situação de diversas cidades.

Mas é fato que a não conclusão do processo de desapropriação se tornou um agravante a não eficácia do planejamento urbano de contornos modernistas. A mescla entre naturezas jurídicas distintas das terras e a própria dificuldade inerente no início do processo contribuem para a complexidade do cenário atual.

Citando as diferentes naturezas jurídicas das terras encontradas no Distrito Federal é que se percebe o grau de dificuldade fundiária ${ }^{175}$ : terras devolutas, de domínio público, que não se acham no domínio particular por qualquer título legítimo e não foram objeto de ação discriminatória; terras públicas, agregadas ao patrimônio público por desapropriação ou doação; terras particulares registradas no Cartório de Registros de Imóveis do Distrito Federal possuindo ainda matrículas de registros dos cartórios de Luziânia, Planaltina ou

${ }^{174}$ GDF/SEDUMA - Secretaria de Estado de Desenvolvimento Urbano e Meio Ambiente (antiga SEDUH) - Documento técnico, 2007 - disponibilizado pelo site: http:// pdot.seduh.df.gov.br ; Acesso: 25 de maio de 2007, pág. 103.

175 Já descrito de forma pormenorizada no sub-item: Aquisição de Terras e o mito da terra pública. 
Formosa, sendo, por isso, por vezes contestáveis; terras públicas e privadas em regime de propriedade comum, adquiridas pelo Estado por desapropriação ou compra direta, ainda não submetidas ao processo judicial ou amigável de divisão; e até terras onde se desconhece o proprietário.

Mesmo as terras da primeira natureza, consideradas de domínio público, encontram, por vezes, sua contestação jurídica, por particulares que alegam sua propriedade, ou trâmite jurídico não findo. Essa complexidade de situações fundiárias caracteriza o arcabouço primordial desse território.

São vários os tipos de ação que se tornaram comuns ao parcelamento de terras por particulares, sejam elas públicas ou privadas, um deles parte do desmembramento de glebas rurais do DF. Respeitando a regulação federal que permite o desmembramento de glebas rurais tendo em vista as legislações e condições determinadas pelo Instituto Nacional de Colonização e Reforma Agrária - INCRA, proprietários privados de glebas rurais, começam a ofertar no mercado imobiliário, de modo pulverizado nas glebas particulares, possuidoras de títulos de propriedade, chácaras com o módulo mínimo de 2 hectares $^{176}$.

Este desmembramento das glebas em pequenos módulos rurais geralmente é destinado a uma demanda de compradores que vêem a possibilidade de aquisição de um espaço destinado ao lazer particular. Faz-se essa observação já que a demanda por pequenos lotes de chácaras nem sempre está inserida nos ciclos de produção agrícola relacionada à produção rural destinada ao abastecimento do mercado consumidor. Ou seja, parte considerável dos adquirentes não é representada por um investidor ou produtor rural, caracterizando um uso para o terreno que é comumente denominado de chácaras "de veraneio" ou "de fins de semanas", que visa mais especificamente ao lazer.

Esse tipo de ação tende a uma maneira quase que "natural" dentro do que poderia ser

${ }^{176}$ em específico ver decreto n. 62.504 de 08 de abril de 1968, que "regulamenta o artigo 65 da lei 4.504, de 30 de novembro de 1964, o artigo 11 e parágrafos do decreto-lei 57 , de 18 de novembro de 1966, e da outras providencias", que regula também sobre o desmembramento rural para atividades diversas das estabelecidas como rurais, podendo ser autorizadas parcelas menores que 2 hectares, desde que a área resultante para a atividade rural não seja inferior a este módulo rural. $\mathrm{A}$ área destinada a outra atividade poderá ser menor que 2 hectares, sendo ela o mínimo indispensável para o funcionamento da nova atividade, dentre elas destaca-se as que podem ser consideradas de indutores de ocupação destinados ao uso comercial:1) postos de abastecimento de combustível, oficinas mecânicas, garagens e similares; 2) lojas, armazéns, restaurantes, hotéis e similares; 3) silos, depósitos e similares. 
identificado como o processo de urbanização, no qual há a substituição das atividades rurais por outras atividades mais vinculadas à vida urbana ou extensão dela, numa forma gradativa que podemos caracterizar como a "degradação" do ambiente rural em contrapartida à ascensão do ambiente urbano. Uma maneira de substituição de usos e mudança de valor, onde a valorização da terra deixa de ser vinculada à sua capacidade produtiva, mas sim à sua localização em relação ao núcleo urbano e à infra-estrutura urbana instalada.

Esse subúrbio, nem sempre é contíguo à área urbana, mas sempre próximo a ela.

A partir do desmembramento dessas glebas em terrenos menores, segue-se a subdivisão em terrenos já com características mais urbanas já que o tamanho não se adequa à produção rural, podendo ser encarado como outro tipo de ação empreendedora para a préqualificação do terreno a um loteamento.

A subdivisão não é necessariamente subseqüente ao desmembramento das áreas particulares, a subdivisão em terrenos menores que 20.000 metros quadrados era vetada aos particulares até 1992, já que caracteriza parcelamento do solo destinado ao uso urbano. Assim, a ação de divisão de lotes menores de 2 hectares não encontrava respaldo legal, pois depende da autoridade local para regularizá-lo.

Isso não impediu a concretização do que é denominado de condomínio irregular, condomínio ou loteamento clandestino, ou, como denominado atualmente pelas autoridades locais, loteamentos informais.

O condomínio foi a forma legal que parte dos "empreendedores" se utilizaram para obter uma pretensa legalidade, já que não caracteriza uma subdivisão de fato, mas uma situação de co-domínio da gleba, o que não isentava a necessidade de regulação tendo em vista o uso urbano que acabou por caracterizar. Para o empreendedor do condomínio, uma convenção condominial, respeitando os ditames do código civil, substituía o planejamento urbano e regulação estatal, poços artesianos substituíam o abastecimento de água e fossas sépticas o esgotamento sanitário.

A pavimentação asfáltica, não incluída no início da incorporação do condomínio, é posteriormente executada pelos condôminos, a iluminação interna também. Esses microcosmos, pretensamente independentes das ações do Estado, ofertados ao mercado com valores muito baixos são extremamente atrativos.

Nesse processo de construção do urbano pelo empreendedor privado, que sem autorização legal vai parcelando o solo, ocupa área estimada pelo GDF em 46.000 hectares, $8 \%$ de todo o território do Distrito Federal. São aproximadamente 80.000 lotes se considerados apenas os 368 parcelamentos destinados à população de renda média, com características 
urbanas.

Essa ação de constituição de condomínios não se restringiu a terras particulares, mas também se utilizou de glebas estatais, aproveitando-se inclusive da precariedade de alguns títulos de propriedade contestados desde a época da Comissão de Cooperação.

Nas terras públicas, a subdivisão se deu a partir das glebas concedidas para atividades de produção agrícola determinadas por programas locais. Eram Núcleos Rurais, Colônias Agrícolas e Agrovilas, onde, por meio arrendamento os produtores poderiam contar inclusive com apoio técnico. Esses programas vão se desmontando a partir da década de 80 , sendo quase que dizimados na década de 90, com a extinção da Fundação Zoobotânica.

A Fundação Zoobotânica criada em 1975 para o controle e gerenciamento da área rural, assume atribuições antes a NOVACAP, no âmbito do Distrito Federal, cabendo a ela também administrar os arrendamentos e concessões de uso das terras públicas rurais.

Havia um esforço administrativo, para manter e incentivar a produção agropecuária no território do Distrito Federal, inclusive com manutenção e gerenciamento de pontos de revenda da produção. Esse esforço em muito se devia ao entendimento de que as áreas do Distrito Federal, também forma escolhidas, devido a suas características de relativa fertilidade, e em território plano e bem irrigado. ${ }^{177}$

É também em 1975 que oficialmente se identifica ${ }^{178}$ a primeira ação irregular de loteamento por particulares. Esse marco esconde uma ação que acompanhou sempre a evolução urbana da capital, pois desde o início dos trabalhos da Comissão de Cooperação observase o parcelamento do solo por particulares de forma ilegal. E se fosse o intuito remontar o processo de loteamento do Distrito Federal, ao que tudo indica, tendo em vista os relatórios de Altamiro de Moura, seria importante retroagir o histórico a 1955 aos primeiros registros da Comissão.

Como curiosidade, a extinção da Fundação Zoobotânica se deu na mesma data da criação da Secretaria de Estado de Assuntos Fundiários - SEAF, em 21 de janeiro de 1999. Essa secretaria se destinava ao planejamento, execução e implementação da política de regularização das terras urbanas e rurais do Distrito Federal. Ressalta-se que durante os

\footnotetext{
${ }^{177}$ Esta observação pode ser constatado nos relatórios Belcher e no relatório final da Comissão de Estudos para a Localização da Nova Capital (de 4 de agosto de 1948).

178 Alguns pesquisadores marcam como surgimento do primeiro loteamento irregular o Mansões Country Club o ano de 1975, baseados em dados oficiais do GDF.
} 
quatro anos de sua existência não conseguiu realizar as devidas ações discriminatórias com demarcação de terras.

A extinção de uma fundação que era responsável pelo incentivo e administração das terras rurais de propriedade estatal, com a criação de um órgão para agir na regularização das mesmas áreas que o primeiro deveria zelar, põe em evidência a dificuldade de convívio das duas matrizes econômicas. A rural, que num âmbito nacional por não propiciar condições ao pequeno produtor incentiva a migração destes aos centros urbanos que não conseguem absorvê-los esse contingente de trabalhadores, em um âmbito local, pois, não conseguem, direcionar esses trabalhadores rurais, aptos à produção agropecuária a terras públicas, destinadas à produção local, inclusive sem ônus de aquisição, com disponibilização de assistência técnica e centros de revenda e distribuição etc.

A outra matriz é a urbana que se apossou da terra como bem imobiliário, e que, mesmo tendo regulação rigorosa e, monopólio do Estado nas ações de parcelamento e uso do solo, não realizou ações suficientes para uma solução diferenciada dos problemas de habitação, por exemplo.

TABELA IX. Parcelamentos considerados "informais" implantados ou não, de acordo com o período de levantamento oficial do Governo do Distrito Federal.

\begin{tabular}{ll}
\hline Ano de Levantamento & Quantidade de loteamentos identificados \\
\hline 1975 & 1 \\
1985 & 150 \\
1989 & 179 \\
\hline 1995 & 529 \\
2002 & 507 \\
\hline 2006 & 513 \\
\hline 2008 & 586 \\
\hline
\end{tabular}

Fonte: GDF/SEDUMA - Diagnóstico Preliminar dos Parcelamentos Informais no Distrito Federal - julho/2006; dado de 2008 divulgado pelo jornal Correio Braziliense de 16 de março de 2008 (fonte: Subsecretária de Defesa do Solo e da Água - SUDESA)

Pelo entendimento oficial, a proliferação dos condomínios deriva das altas taxas de crescimento populacional, devido à migração e à formação de novos núcleos familiares, que levaram também à necessidade de novas moradias para a classe média, tendo em vista a falta de políticas habitacionais dirigidas a este segmento, que provocaram quantidade insuficiente de produção para o atendimento da demanda. Os altos preços dos imóveis no Plano Piloto e adjacências sempre são citados também, e assim, "a constituição de condomínios nas áreas rurais foi a saída encontrada" 
A versão do documento Modelo de Gestão Estratégica do Território do Distrito Federal disponível na internet, ainda afirma que

“(...) diante de uma legislação permissiva e uma fiscalização ineficiente, os condomínios se multiplicaram nas décadas de 80 e 90. A exploração clandestina da terra, tanto em terras particulares quanto em terras públicas, por ação de grileiros, resultou em mais de 50 condomínios em 1988, número que ultrapassou 500, em 1995, sendo que 144 para fins urbanos."179

Entretanto, o que se observa contradiz essa posição, já que até 1992 era vetada a ação do parcelamento do solo por agentes privados particulares para fins urbanos, o que não caracteriza uma legislação permissiva, pelo contrário, ela é fortemente repressiva. O descompasso que se observa é a dissonância com alguns elementos da legislação federal que regula a propriedade rural e as formas de desmembramento autorizadas. Assim, não se identifica, a priori uma legislação permissiva.

Outro fato, é quanto à ação da fiscalização das terras rurais, pois o monitoramento e controle não são, necessariamente, ineficazes no que concerne em identificação e motivação de processos administrativos para desocupação. O processo a ser observado é outro, e está relacionado às formas de defesa do domínio e da posse da terra, que, somadas ao direito à moradia tornam as ações de desocupações mais complexas.

Quanto à fiscalização, é possível apresentar ainda outros pontos, na verdade, a repressão quanto à ação de ocupação. Como visto, nesse capítulo, a situação fundiária de terras possibilitou uma constante contestação sobre a propriedade dos imóveis, além disso, a repressão a ocupação sempre se deu de forma eficiente quando se trata de "invasões" de baixa renda, mas, nas "ocupações" de grupos de média e alta renda, essa ação sempre encontrou muito mais obstáculos com relação a manutenção de posse.

A diferença de atuação se expressa com mais clareza do que se pode admitir, apesar disso, atualmente, com o surgimento de condomínios destinados e ocupados por população de baixa renda, a estratégia de manutenção de posse judicial, também tem sido usada por estes ocupantes, em um processo de universalização dos direitos de posse.

Esse novo cenário provoca uma necessidade em rever as maneiras de atuação nas ações de fiscalização e regularização. E, por isso, certa estranheza é causada, provocando um sentimento de ineficiência da atividade de fiscalização.

179 DISTRITO FEDERAL (BRASIL). Modelo de gestão estratégica do território do Distrito Federal. Brasília: Metroquattro Arquitetura Tecnologia, 2004. 172 p.. p.79 


\section{CAPÍTULO 3 - Brasília e a Formação Nacional: as contradições entre o Planejamento Urbano Modernista e a Sociedade Brasileira}

Retomando Ricardo Faret, entender o momento histórico do surgimento e do fundamento de políticas urbano-territoriais só é possível quando essas se colocam a partir dos momentos históricos e políticos nos quais se inserem. Esses momentos históricos e políticos não são desconectados de um entendimento da sociedade na qual ocorre o fato, mas, antes de tudo, ocorrem como decorrência da própria formação dessa sociedade. É imprescindível esse entendimento.

É por esse entendimento que se foca o capítulo final, o qual busca numa leitura da interpretação de autores que se debruçaram sobre o tema da formação social brasileira e do Estado brasileiro e que, de certa maneira, tem seu reflexo na consolidação de um planejamento urbano que se constrói acompanhando a construção e consolidação de uma estrutura política e social na qual o atrasado e moderno são elementos que paradoxalmente se alimentam.

Caio Prado Júnior, Florestan Fernandes, Celso Furtado, Raymundo Faoro, Francisco de Oliveira e mais recentemente Wanderley Guilherme dos Santos são os teóricos que serão abordados como complemento importante da análise desse trabalho. E para auxiliar na leitura do pensamento dos três primeiros autores, recorreu-se à interpretação que Plínio de Arruda Sampaio Júnior faz sobre a formação nacional.

(possível subtítulo)

Vê-se pelo exposto nos capítulos anteriores que a conjugação de elementos absolutamente distintos da sociedade brasileira que, inserida num processo de formação econômica, busca "queimar etapas" de desenvolvimento a partir de maciços investimentos estatais e de recursos de "poupanças externas", como, por exemplo, Guido Mantega procura demonstrar.

Essa situação provocou um descompasso no crescimento brasileiro inimaginável à época do nacional-desenvolvimentismo juscelinista, e é nessa fórmula que se insere o planejamento 
total $^{180}$ dos modernistas aplicado no Brasil, em específico em Brasília.

Segue citação de Francisco de Oliveira, para iniciar uma reflexão, já que sua forma interpretativa da formação social coliga diversas fontes e aspectos da sociedade, e que para esse trabalho aparece como chave explicativa das situações que se observaram no decorrer da pesquisa.

"O ornitorrinco é uma das sociedades capitalistas mais desigualitárias. (...) As determinações mais evidentes dessa contradição residem na combinação do estatuto rebaixado do trabalho com dependência externa."181

Em O Ornitorrinco de Francisco de Oliveira, o entendimento da formação brasileira passa pela discussão do próprio caráter de desenvolvimento econômico ocorrido no Brasil. Em sua interpretação, esse caráter deve ser analisado levando-se em consideração três aspectos aos quais complementariam a forma do (sub)desenvolvimento brasileiro.

Um dos pontos refere-se à função da agricultura de subsistência para a acumulação interna do capital, refutando a tese do setor atrasado como obstáculo ao desenvolvimento, e sustentando que tal agricultura financiava a agricultura moderna e a industrialização.

Wanderley Guilherme dos Santos ${ }^{182}$ se utiliza dessa mesma posição para explicar o contexto de formação da estrutura estatal a partir de Vargas, em sua primeira estada no governo no período de 1930 e 1945, onde, segundo ele, observamos as bases do Estado nacional brasileiro que persistem até hoje.

Dentro dessa tese do financiamento da industrialização por meio da agricultura de subsistência, Oliveira defende também que a cultura de subsistência ajudou a baixar o custo de reprodução da força de trabalho nas cidades, facilitando a acumulação industrial.

No caso da construção da nova capital, isso foi fato gritante, o que muito colaborou com um sentimento de angústia entre os arquitetos e urbanistas que viam na implantação de preceitos do planejamento total preconizado pelo movimento moderno no todo e, em

\footnotetext{
180 Utilizou-se neste trabalho, a denominação de planejamento total para designar o planejamento urbano modernista, aplicado nos países centrais do Estado Bem-Estar Social, que visavam dar solução ao que identificavam como caos urbano. Essa discussão está no primeiro capítulo, no item sobre os preceitos do CIAM.

${ }^{181}$ OLIVEIRA, Chico - o ornitorrinco - pg 143

182 SANTOS, Wanderley Guilherme dos - o ex-Leviatã brasileiro: do clientelismo concentrado ao voto disperso
} 
específico, no documento da Carta de Atenas, a forma de superação da sociedade arcaica por substituição a uma sociedade moderna igualitária.

Marcando ainda um aspecto que tornava esse sentimento contraditoriamente forte sobre Brasília, à época e numa visão retrospectiva, é que se acreditava que estava em formação o que seria a sociedade espelho do desenvolvimento para o resto da nação, ficando apenas, ao final do processo, a imagem dos candangos, migrantes rurais em sua maioria, sendo inseridos violentamente no mundo da exploração urbano-capitalista, por meio do trabalho na construção civil que ergueu a cidade.

Recolhidos diretamente do campo, eram colonos seduzidos pelo discurso nacionaldesenvolvimentista. Estes subiam em caminhões fretados pelas construtoras, em sua maioria contratadas ou pelo Estado, representado pela NOVACAP, ou por instituições como os Institutos de Aposentadoria e Previdência, e iniciavam uma jornada em direção a metasíntese do desenvolvimento. Então, os colonos adentraram o novo mundo urbano que pretensamente se descortinava pelo planejamento urbano modernista que deu origem ao projeto urbanístico de Brasília, um mundo urbano que o planejamento moderno preconizava como mais igualitário que o anterior.

Destaca-se ainda, que Oliveira aponta para uma imbricação existente também entre agricultura de subsistência, o sistema bancário privado que se implantava, o financiamento da acumulação industrial e o barateamento da reprodução da força de trabalho nas cidades, sendo então que no primeiro e no último aspectos cabem a descrição anterior.

O barateamento da reprodução da força de trabalho leva a outro ponto de Oliveira, o qual é o papel do "exército de reserva" nas cidades. Pois, diferentemente de outros teóricos, não o identifica como sendo apenas uma massa de consumidores de excedente ou lúmpen, mas também como parte integrante das formas de rebaixamento do custo de reprodução da força de trabalho urbana. Na periferia dos acampamentos das construtoras estava esse "exército de reserva" à espera de ser convocado para atuar em nome da "nova sociedade" regida pelo Estado moderno desenvolvimentista, na conclusão da "capital do século XXI".

Dessa maneira, o subdesenvolvimento na interpretação dada pelo Ornitorrinco, viria a ser, portanto, "a forma da exceção permanente do sistema capitalista na sua periferia. (...) 0 subdesenvolvimento finalmente é a exceção sobre os oprimidos". ${ }^{183}$

O último ponto de Oliveira refere-se à adoção do endividamento externo como uma forma de

${ }^{183}$ OLIVEIRA, 2003 p. 131 
financiar o desenvolvimento nacional, e demonstra a falta de esforço em liquidar problemas estruturantes como o patrimonialismo, ou mesmo, a dificuldade na resolução do financiamento interno à expansão do capital.

A NOVACAP sintetiza esse ponto, ao ser capaz de contrair diretamente endividamento externo sem que fosse necessária a solução do patrimonialismo, expresso na burocracia estatal da qual procura ser afastada pela autonomia e ao responder diretamente ao Presidente da República. E, em uma análise, se torna prisioneira do patrimonialismo do qual procura se desvencilhar. Não consegue financiar plenamente o processo de urbanização da capital pela fórmula apresentada como solução do empreendimento, a qual seja, autofinanciamento por meio da comercialização imobiliária dos lotes urbanos, recorrendo a empréstimos internacionais no início para a aquisição, por exemplo, do maquinário de construção civil mais moderno da época.

Recorre, também, ao orçamento da União de forma direta por meio de emendas orçamentárias, para cumprir suas obrigações legais, capta recursos de outros organismos estatais, via contratos de compra e venda de terrenos, para execução de obras civis para a moradia do corpo burocrático, ou para as obras civis das sedes. A companhia buscava estabelecer fórmulas contábeis para sua viabilização como "empresa industrial" ${ }^{184}$, mas toda ela dependia da capacidade de investimento do Estado.

Outro aspecto vinculado ao patrimonialismo, que afetou a materialização da capital, é a situação fundiária, que foi mais bem observada para esse trabalho. Um fato é, no mínimo, curioso: o membro da diretoria executiva da companhia, ao qual se vinculava o processo de desapropriação, era, nada menos, que um deputado federal de partido opositor (UDN), um grande fazendeiro e latifundiário, ex-presidente de uma associação nacional de ruralistas, que mais se interessou, por exemplo, em implantar "cidades rurais" dentro do Distrito Federal, cita-se Sobradinho e Gama, do que em se preocupar com a rigorosidade e solução de ambigüidades verificadas nos registros de terras.

A posição de Iris Meinberg no controle desse processo nunca foi estudada ${ }^{185}$ e, no mínimo,

${ }^{184}$ Expressão de Juscelino Kubitschek

${ }^{185}$ Não se encontrou durante as pesquisas realizadas para a revisão bibliográficas, ou mesmo em documentos do arquivo público e em trabalhos acadêmicos recentes, estudo sobre esse personagem. E menção à sua atuação na NOVACAP, sempre é tratada como periférica, não representativa, mas, pouca coisa explica a dificuldade em se encontrar registros sobre a atuação da companhia nas ações de desapropriação no período de 1956 a 1959. Como marcado, entre 1955 e 1958, quem atuou de 
aparece como a reprodução do acordo que marcou a possibilidade de aplicação do Plano de Metas e possibilitou a construção da nova capital no interior do país. Sua atuação até mesmo como Diretor Financeiro da companhia e pouco vista como algo importante. Ainda, a subordinação do Departamento de Terras e Agricultura a sua diretoria não buscou respeitar aquilo que estava em seu controle, a qual seja as terras rurais, implantando diversos Núcleos Rurais em terras ainda de propriedade privada. Fica assim um objeto de estudo aparentemente vasto ainda esperando muitas interpretações e pesquisas.

Retomando a interpretação de Oliveira quanto à forma do subdesenvolvimento brasileiro, apresentada pela itemização extraída de O Ornitorrinco, representa a resposta a uma interpretação cepalina ao desenvolvimento dos países periféricos. Segundo o próprio autor, sua crítica pertence ao campo marxista e cepalino, e sendo assim, observa a política de forma estruturante e não como um fator externo ao processo de formação do capitalismo periférico.

É necessário aqui fazer um recorte para apresentar questões importantes sobre a formação social e o Estado brasileiro, que serão fundamentais para o próprio entendimento das posições já citadas de Oliveira.

Para Plínio de Arruda Sampaio Junior, parte-se do pressuposto que, o Estado democrático e republicano é o reflexo da formação da sociedade e de como os mecanismos nacionais estão formatados para o atendimento dos interesses sociais. Esta premissa tem por preceito teórico a própria natureza do Estado, como sendo este resultado socialmente construído.

No caso brasileiro, e para propiciar um bom entendimento das questões abordadas, buscase o que poderia identificar e explicar as condições que segundo alguns autores, como Sampaio Júnior, emperram a plena integração do Brasil na civilização ocidental, tendo em vista como "a herança colonial e a posição subalterna no sistema capitalista mundial comprometem a capacidade dos brasileiros de governar o seu destino" ${ }^{186}$.

Observada então a nova capital sob esse prisma, tentando traduzir essa visão macro ao micro do espaço urbano; a herança colonial que diretamente afeta a constituição do espaço urbano está no intricado e falho procedimento de registro de terras, marcado pelos Registros Paroquiais que na região ocorreram entre 1855 e 1858, que expõe a precariedade do

fato nesse processo, foi a Comissão de Cooperação para Mudança da Nova Capital, fazendo acordos e desapropriando quase que um terço do Distrito Federal.

186 SAMPAIO JR, Plínio de Arruda, - O impasse da formação nacional in: FIORI, José Luiz (org)Estados e moedas no desenvolvimento das nações, Petrópolis, Editora Vozes, 1995p 415 
domínio e posse das terras. Sem um rigoroso e eficaz controle de transações fundiárias, que deveria ser executado pelo Estado criou-se um cenário extremamente complexo, que ainda hoje é alvo de intensos levantamentos por parte da administração pública. Em Brasília, não só por exigência da lei que criou o Distrito Federal, obrigando o Estado a desapropriar todo o território do quadrilátero, como também, as situações que se criaram posteriormente, fez com que surgisse uma quantidade considerável de organismos estatais para regular a terra, desde formas de policiamento até uma Secretaria de Estado de Assuntos Fundiários, com a única atribuição de dar solução ao problema.

A questão fundiária é, no entendimento desse trabalho, a característica mais claramente herdada do período colonial expressa no início do processo de construção da capital, a qual influencia e interfere sobremaneira, a capacidade de resolver o desenvolvimento urbano local, mesmo com os mecanismos criados e comandados por uma companhia de grande autonomia como a NOVACAP.

Retornando a análise de Sampaio $\mathrm{Jr}$, sobre o contexto de subordinação ao sistema capitalista mundial, é possível perceber uma ligação secundária entre o urbano da capital e o Estado subalterno brasileiro. Brasília é o principal espaço físico de reprodução do corpo burocrático nacional, e, é a forma urbana concretizada de uma política nacional de desenvolvimento. Os investimentos nesse espaço foram resultado da capacidade do Estado central em investir no urbano, pois nunca se pode desvincular a produção do espaço urbano em Brasília do Estado nacional, como se fosse uma simples capacidade da administração local de investir recursos arrecadados, pois, seu orçamento era item constante do orçamento da União. Ou seja, era o Estado central o gestor dos recursos da cidade até $1985 .^{187}$

No campo teórico das ciências políticas a afirmação de Sampaio Júnior tem respaldo na teoria de Estado de Louis Althusser e Nicos Poulantzas ${ }^{188}$, na questão da "autonomia relativa" do Estado que, no caso do Brasil, se torna cada vez mais limitada devido a uma imposição externa às políticas locais de aplicação de recursos e investimentos. Além disso, existe a necessidade de garantir as formas de reprodução do grupo dominante que, no

\footnotetext{
187 Observa-se uma inflexão anterior a 1985, mais precisamente em 1980, quanto aos recursos e a estrutura administrativa do governo do Distrito Federal, na qual um contínuo e paulatino aumento de arrecadação via impostos e taxas urbanas associada a uma crescente independência do Orçamento Geral da União - OGU, marcam o início de um novo período para a história da cidade.
}

${ }^{188}$ POULANTZAS, Nicos. O Estado, o poder, o socialismo. São Paulo: Terra e Paz, 2000. 
Brasil do nacional-desenvolvimentismo de $\mathrm{JK}$, eram os grandes proprietários de terras formadores da base dos dois maiores partidos UDN e PSD. Esse respaldo a que se refere tem por explicação a própria condição do modo de produção capitalista.

A hipótese que Sampaio Jr levanta quanto a essa formação emperrada é que

"O problema consubstancia-se na necessidade de assegurar a continuidade de processos históricos responsáveis pela consolidação das bases materiais, sociais, espaciais, políticas e culturais do Estado nacional”189.

Existe uma contradição que pode ser observada pela condição de barbárie e pelo processo civilizatório, estados considerados latentes na sociedade dependente. Sendo que a primeira se deseja evitar e o segundo se pretende alcançar, ou seja, dois pólos de mudança social onde em um reside a idéia de progresso que contribui para a consolidação da civilização brasileira e, no outro, a noção de decadência. Essa situação coligada leva ao que se define como reversão neocolonial.

No plano urbanístico da capital é isso que se pretende, edificar um exemplo a ser reproduzido, que ponha fim ao caos urbano identificado pelos urbanistas modernistas como a barbárie da cidade, e implemente um processo de desenvolvimento moderno civilizatório do interior do país, sob a ótica do urbanismo modernista.

De uma forma geral, segundo Sampaio $\mathrm{Jr}$, todos os pensadores que se debruçaram sobre o assunto da formação nacional ressaltaram basicamente os mesmos pontos que dificultam a afirmação nacional, sendo eles: o genocídio da civilização pré-cabralina; o ultra-elitismo de uma sociedade incapaz de resolver suas pendências com relação ao passado escravista; o caráter predatório assumido pela atividade econômica; a extrema vulnerabilidade do país às vicissitudes do capital internacional; a inadequação da base produtiva; os obstáculos à afirmação do domínio do território nacional; a falta de identidade nacional de um aglomerado humano recente; a precariedade das instituições administrativas e políticas que compõem o Estado; e o arraigado colonialismo de nossas elites.

A capital federal vem responder aos sete últimos pontos levantados dos oito enumerados, pois o ponto sobre o genocídio da civilização pré-cabalina é o que representa uma ruptura não narrada na história de Brasília. O Brasil da nova capital tem sua história contada a partir da dominação portuguesa, como foi visto no primeiro capítulo e não representa uma questão de reconhecimento dos povos indígenas, pelo contrário, ignora sua existência.

${ }^{189}$ Idem pg 416 
Aqueles que refletiram a partir de uma perspectiva democrática vinculam a construção do estado à integração do conjunto da população, vislumbrando que "a idéia de que os problemas do país não serão resolvidos sem transformações socioculturais profundas, que criem base de uma sociedade eqüitativa e auto-referida"190 , ou seja, a afirmação da nacionalidade deriva de uma consolidação de uma sociedade homogênea, baseada em ligações morais entre as classes sociais e na união e imbricamento das diferentes regiões do país. Como visto, isto se filia ao discurso da nacional-desenvolvimentismo, onde o reconhecer o interior é a forma de afirmação da nacionalidade.

E aqui está um ponto que a própria urbanização do Brasil propõe marcar por meio da inclusão da população ao novo urbano e, como visto, Brasília é essa síntese expressa na ideologia nacional-desenvolvimentista. Contudo, retomando Martins, essa inclusão do excluído, na verdade, é feita de maneira a caracterizar uma nova desigualdade, que no contexto urbano, segundo Oliveira, serve ao ciclo de reprodução do "ornitorrinco".

O espaço nacional, pela perspectiva democrática, é apenas uma ferramenta para proteção da coletividade das transformações oriundas do centro capitalista mundial que possuam efeitos destrutivos, como também serve ao planejamento das estruturas e dinâmicas da civilização ocidental, de forma condizente com o aumento do grau de autonomia e criatividade da sociedade e com a elevação da riqueza e bem-estar do povo. A forma nacional acima descrita pretende estabelecer o controle de seu tempo histórico, só sendo superada com formas superiores de organização social e política que, em uma ordem mundial, deixasse de estar sob o domínio de uma lógica de concorrência intercapitalista e das rivalidades imperialistas. O nacional-desenvolvimentismo juscelinista, que gerou a metasíntese, procura responder a essa condição por meio da industrialização.

A tradição democrática parte da suposição que se

"(...) a contradição gerada pela posição subalterna no sistema capitalista mundial não foi inconciliável com a continuidade dos processos responsáveis pela constituição do Estado nacional, a nação emergente cresce e se desenvolve no bojo do capitalismo dependente. No entanto, quando a contradição se converte em um antagonismo irredutível, o capitalismo dependente se divorcia completamente da sociedade nacional, tornando-se incompatível com a continuidade do processo civilizatório. Daí em diante, a

\footnotetext{
${ }^{190}$ Sampaio Júnior cita alguns deles que são de suma importância para a construção do pensamento nacional destacamos: Oliveira Viana em Populações Meridionais no Brasil, Gilberto Freyre em Casa Grande \& Senzala, Sérgio Buarque de Holanda em Raízes do Brasil e Antônio Cândido em Formação da Literatura Brasileira. Ver SAMPAIO JR, 1999 p.417
} 
sociedade passa a viver uma encruzilhada decisiva de seu processo formativo, pois a ruptura com as estruturas externas e internas que sustentem a ordem passa a ser o único meio de evitar a barbárie.,191

A conclusão possível, advinda desta suposição de Sampaio Júnior, permite que a sociedade entre em uma conjuntura revolucionária com dois desfechos, sendo um que propicia a abertura de um novo horizonte - a revolução brasileira - e o outro o reforço do retrógrado sufocando o futuro e projetando a sociedade ao passado - a contra-revolução - o que seria o fim da construção da nação Brasil. Na verdade, aqui se cria um ponto de reflexão, pois para Oliveira essa condição do reforço do retrógrado é a natureza da sociedade ornitorrinco.

Este ponto de inflexão, ao qual Sampaio Júnior se refere, é convergente nos três intérpretes descritos anteriormente: Caio Prado Júnior, Florestan Fernandes e Celso Furtado, tendo nos anos entre 1950 e 1980 sua definição na contradição entre o capitalismo dependente e a formação da nação de forma aberta. Em um resumo possível de Caio Prado Jr, o controle pelo capital internacional sobre o processo de industrialização por substituição de importações - fenômeno que ganha ímpeto no pós-guerra, particularmente com a política desenvolvimentista de Juscelino Kubitschek - gera uma tendência irreversível à reversão neocolonial.

Já Florestan Fernandes, por meio de observações de circunstâncias internas e externas pré-golpe de 1964 - constatou que este período permitiu que a burguesia consolidasse seu padrão de dominação e preservasse seu poder de negociação no sistema capitalista mundial, evitando, assim, a reversão neocolonial (ainda que à custa do reforço de seu caráter anti-social, antinacional e antidemocrático).

$\mathrm{Na}$ interpretação de Celso Furtado, a incapacidade de defender a economia brasileira dos efeitos estruturantes da transnacionalização do capital, sobretudo após a eclosão da crise da dívida externa no início da década de 80 , passou a comprometer a continuidade da construção nacional, pondo em questão a própria unidade territorial do Brasil ${ }^{192}$

Não se pode deixar sem referência que, durante toda a década de 60 e 70, a política econômica ainda se baseava num forte viés nacional-desenvolvimentista, da industrialização por substituição de importações. A capital, nesse período, reafirma seu caráter de pólo de atração de migração, sendo que é na década de 70 que se consolida como aglomerado urbano e capital da república. No cenário local, é nessa década que são verificadas as mais

\footnotetext{
191 SAMPAIO JR, 1999, p. 416

192 SAMPAIO JR, 1999. p 418
} 
extraordinárias remoções de "invasões" de terras, principalmente se observada a proporção entre invasores removidos para aglomerados satélites planejados e população total residente. Ainda não se pode deixar de comentar que a década de 70 é representativa para a consolidação do Brasil urbano em detrimento do Brasil rural, com o aumento significativo da miséria, expondo e realçando as desigualdades, e é na década de 80 que aparece como a imagem resultante dos processos econômicos e sociais pregressos, a miséria urbana consolidada.

Detendo-se um pouco mais a Caio Prado Junior, para esse autor, a formação do Brasil contemporâneo é impulsionada pelas reações inconformistas provocadas por um profundo mal-estar em relação à pobreza, ao atraso, à instabilidade e à racionalidade que, de forma genérica, caracterizam o cotidiano brasileiro. É, então, um longo processo que acaba por levar ao aparecimento de uma diferenciação progressiva entre o colonizador português e um novo personagem histórico, que é o brasileiro.

Em seu entendimento, a formação do Brasil é resultado da disputa entre o sistema imperialista e a progressiva mercantilização da sociedade, indo de encontro a um grau mínimo de estabilidade para o desenvolvimento capitalista, que seria o desafio da nação emergente.

Daí o surgimento de uma ilusão de riqueza e prosperidade advinda de conjunturas internacionais, quando estas estão a privilegiar um determinado produto, ou seja, uma criação de uma realidade que se desmorona como um verdadeiro castelo de areia quando há mudança da maré. Uma mudança no mercado internacional é suficiente para detonar uma crise que pode desmoronar a economia interna, já que nesse clima auspicioso sobre determinados produtos, se mobiliza populações, territórios, estruturas inteiras. Assim, instalam-se os movimentos cíclicos que são determinados por este ou aquele produto, tendo os momentos de auge e declínio. Como se o produto regesse a condição da sociedade, a própria reificação.

Para a consolidação do Brasil com existência autônoma e força própria, Caio Prado Jr entende que é necessária a criação de condições e bases objetivas e subjetivas que estimulem o desenvolvimento de forças produtivas voltadas para o mercado interno, e que aumentem a diferenciação entre os interesses nacionais e estrangeiros. Esse entendimento vem da observação que se faz das dinâmicas econômicas e demográficas, crescentes geradoras de diferenciação entre os objetivos mercantis e as necessidades e aspirações à melhoria de vida. A economia de base colonial também não permite, ao crescente mercado interno consumidor, uma expansão e uma diversificação do sistema produtivo, comprometendo a sustentação da "jovem nação". 
O momento da crise de 1929, dá bases a essa interpretação de Caio Prado Jr, onde a contração do mercado internacional e a economia primário-exportadora iniciam o período de crise do sistema colonial brasileiro, que era desarticulado da divisão internacional do trabalho, segundo ele. Além disso, via que essa situação era uma contradição de aspecto irredutível, abrindo assim, novas perspectivas para a economia brasileira que criou uma conjuntura que estimulava a industrialização por substituição de importações.

"A industrialização contribuía, então, para a generalização das relações assalariadas, para a intensificação da urbanização, para a maior integração nacional, para um expressivo desenvolvimento das forças produtivas voltadas para o mercado interno e para o fortalecimento da base empresarial"193

O que muda radicalmente a partir do pós-guerra, pois "o controle do capital internacional sobre os setores dinâmicos da indústria comprometeria irremediavelmente o movimento de nacionalização da economia brasileira"194, devido à presença dos grandes trustes multinacionais que se tornam dominantes e reforçam laços de dependência externa. $A$ fórmula adotada pelo Plano de Metas para incrementar os investimentos no setor, para financiar a expansão industrial, contava com o recurso das "poupanças externas", ou seja, dependia do capital internacional para se viabilizar.

De fato, este é o primeiro ponto, onde o capital externo auxilia a expansão da base produtiva e a internalização das indústrias de bens de capital e consumo duráveis, mas gera uma distorção no mercado interno, pois exige um consumidor de maior renda, ou seja, resulta numa configuração tão distorcida que propicia uma maior concentração da renda. A divisão que se desenha, nesse modelo que segmenta ricos e pobres, tende a comprometer a continuidade do movimento de industrialização, pois limita a capacidade de consumo de porções cada vez maiores da população, dificultando as escalas de produção, diminuindo por conseqüência a importância do mercado interno em relação ao mercado externo. $O$ reforço dessa condição de concentração se insere na interpretação de Francisco de Oliveira, quanto ao rebaixamento dos salários como forma de viabilizar a industrialização brasileira, a desigualdade então ocorre por combinação de concentração de renda e barateamento.

Um parêntese oportuno a leitura Caio Prado Jr, segundo Maurício Vaitsman em Quanto Custou Brasília ${ }^{195}$, a NOVACAP, para viabilizar parte dos investimentos em infra-estrutura

\footnotetext{
193 SAMPAIO JR, 1999, p 420

194 Idem p.421

195 VAITSMAN, Maurício. Quanto Custou Brasília. Coleção Livro-Verdade, Rio de Janeiro: Editora
} 
da capital, contraí empréstimos internacionais em um montante aproximado de dez milhões de dólares. Arrisca-se então em afirmar que Brasília entra na contabilidade da industrialização nacional, que se utilizou de recursos de poupança externa, financiando a indústria da construção civil.

Não é uma consideração sem efeito futuro, já que, a indústria que viabiliza a economia local durante as duas décadas iniciais é a da construção civil e à ela que recorrem os excluídos, ofertando sua única mercadoria, sua força de trabalho. E ainda importante verificar que, em parte considerável dos casos, era o Estado quem financiava a produção, buscando seguir o preceito do planejamento urbano de matriz modernista dos países do Estado do Bem-Estar Social. Pode-se até perceber que essa forma de financiamento direto do poder central contribuiu para a minimização da precarização dos espaços de Brasília, se observada a condição nacional, mas não deu conta de impedi-la.

Parte dos empréstimos internacionais feitos pela NOVACAP acabou por ter influência em seu fluxo de recursos, comprometendo, por exemplo, sua capacidade de re-investimento em infra-estrutura. Os recursos disponibilizados no início da construção e o autofinanciamento via incorporação imobiliária estatal não dão conta dos maciços investimentos necessários ao pleno desenvolvimento da cidade dos primeiros anos, de forma que o orçamento do Estado central é uma fonte importante de recursos. O planejamento urbano modernista do estado do Bem estar Social necessita de uma capacidade gigante de recursos e investimentos de toda a ordem.

Como João Sette Whitaker Ferreira aponta em seu livro, O mito da Cidade-global, ao se referir aos custos do Estado do Bem-Estar Social dos países industrializados:

“(...) Em especial, a partir da década de 50, a consolidação do Estado de Bem-Estar Social nos países industrializados levou a uma expansão global das indústrias multinacionais em direção ao mundo subdesenvolvido, o chamado imperialismo, na prática um típico processo de 'globalização' do capital produtivo. Isto porque não só o Estado do Bem-Estar Social custava caro, como ele limitava sobremaneira a possibilidade de realização da mais-valia, ao aumentar significativamente os custos de reprodução da classe trabalhadora e diminuir as taxas de lucratividade."196

Associado ao fato descrito acima, o capital internacional busca o controle dos elos

Posto de Serviço, 1968.

${ }^{196}$ FERREIRA, João Sette Whitaker. O Mito da Cidade-Global: o papel da ideologia na produção do espaço urbano. Vozes; São Paulo: Editora Unesp; Salvador: Anpur 2007, pág. 42 
estratégicos da indústria brasileira, segundo Prado Jr, dificultando, ou impedindo, a consolidação de uma base empresarial fortemente vinculada ao processo econômico nacional, o que gerava "uma crescente assimetria entre o grau de desenvolvimento das forças produtivas e as bases técnicas e financeiras da iniciativa privada nacionap"197, expresso também na dificuldade transferência de tecnologia e inovações às empresas nacionais que não podiam mais contar com as melhores fontes de financiamento, já que estas estavam a serviço desses grandes trustes. Esse processo, identificado na década de 50 , levou o autor a alertar sobre a desnacionalização crescente da economia local.

Os grandes trustes provocavam esse bloqueio à transferência de inovações, e, por isso, é o terceiro elemento a ser somado à interpretação de Prado Jr. A presença destes nos setores estratégicos da indústria, o que não proporcionava uma devida internalização e capacitação tecnológica do país, muito menos um aumento da competitividade do parque produtivo, pois não havia interesse em investir no desenvolvimento tecnológico da economia brasileira, mas apenas no controle do mercado interno.

A entrada maciça de capital estrangeiro é o quarto elemento, que tem por objetivo explorar as oportunidades geradas pela ampliação do mercado interno, intensificando um desequilíbrio estrutural baseado na remessa de lucros e juros para o exterior que, por sua vez, não são repatriados devido à sua grande mobilidade provocada pela integração da economia brasileira ao mercado financeiro internacional.

"O ponto fundamental da argumentação de Caio Prado é que a discrepância entre a riqueza acumulada nas mãos do capital internacional e a capacidade de gerar divisas significava uma forte elevação da dependência financeira e uma mudança de qualidade no grau de incerteza cambial da economia brasileira"198

É reconhecida por Caio Prado que, esta intensificação da industrialização ocorrida no pósguerra, é uma industrialização dependente, já que se baseia na revitalização das exportações de produtos de baixo conteúdo tecnológico, e, uma vez que houvesse algum processo de reversão dos fluxos de capital das empresas multinacionais, em certa medida, e, para sobrevivência dessa industrialização, seria necessária uma contração no mercado interno para que a produção fosse direcionada às exportações como forma de garantir a transferência de recursos ao exterior e seus compromissos com o capitalismo central.

O fato é que o mercado interno experimentava, naquele momento, uma expansão, o que

\footnotetext{
${ }^{197}$ SAMPAIO JR, 1999 p. 422

${ }^{198}$ SAMPAIO JR, 1999, p. 423
} 
representava um grande conflito entre a necessidade das grandes transferências para o capitalismo central e o processo de formação do Brasil enquanto nação. Este conflito vem por caracterizar um compromisso existente das empresas multinacionais com o processo de industrialização por substituição de importações, que estava então limitado a oportunidades de negócios muito bem definidas, que sujeitaria o processo a uma possível estagnação, já que se procurava debilitar a capacidade de consumo interno, e limitar o tamanho do mercado consumidor, o que Sampaio Jr identifica de uma reversibilidade estrutural, tendendo a uma reversão neocolonial. Em outras palavras, o mercado consumidor interno não poderia sufocar a capacidade de exportação das grandes empresas multinacionais.

Uma conjectura possível, segundo Sampaio Jr, é que a contradição entre o sistema imperialista e a formação da nação brasileira chegou a tal ponto que era possível identificar a consumação da revolução brasileira. Nessa identificação, denota-se o movimento de revolução e contra-revolução - representado por aqueles que não queriam perder o status quo.

A revolução era enxergada pelo crescimento do excedente de mão-de-obra, concentrado nos grandes centros urbanos, em escalas até então não imaginadas. Uma convulsão social estava por ocorrer. Foi então, em meados da década de 60 que Caio Prado afirma a condição insustentável que se encontrava a sociedade brasileira e a necessidade de mudanças profundas.

Mas, no período que se segue, há uma retomada de crescimento da economia bancada pelo endividamento externo, e a diversificação industrial, com internalização de parte significativa da tecnologia da segunda revolução, de forma acelerada, que levou a supor que não havia incompatibilidade incontornável entre dependência e desenvolvimento nacional.

É no início dos anos 80 que as advertências de Caio Prado Jr começam a mostrar sua pertinência, como expõe Sampaio Jr. Essas advertências são a crise da dívida externa, o colapso das finanças públicas, a desarticulação do sistema monetário, a estagnação do crescimento, a submissão incondicional aos ditames da comunidade financeira internacional, o desmantelamento do Estado nacional, a exarcerbação de conflitos federativos, o aumento assustador do desemprego, a progressiva desnacionalização da economia e a elevada vulnerabilidade do parque industrial ao novo padrão de concorrência internacional.

É exatamente nesse período que se observa na construção do espaço urbano de Brasília um momento de mudança considerável na produção habitacional, por exemplo. Em 1980 e 1982 nenhuma unidade é ofertada pela Sociedade de Habitações de Interesse Social SHIS, caracterizando a década de 80 como um período com menor relação de oferta e 
demanda. Comparada com a década de 70 que consolida a capital, os recursos destinados pela SHIS ao atendimento habitacional caem exponencialmente de aproximadamente dois bilhões de reais a preços de dezembro de 2007, a trezentos milhões de reais, quase um sétimo do total investido, tendo a população total quase que duplicado (dados da CODEPLAN registram: em 1970, 558.392 habitantes; em 1980, 1.198.142 habitantes; em 1990, 1.552.650 habitantes; em 2000, 2.051.146 habitantes e; em 2005, 2.277.258 habitantes). Uma parte enorme destes recursos aplicados pela SHIS era oriunda do $\mathrm{BNH}, \mathrm{O}$ agente financiador que substituiu parte considerável dos recursos da União na produção da capital.

Obviamente, a matriz do planejamento urbano modernista, baseada na subvenção estatal para a consolidação do bem-estar social por meio da produção das infra-estruturas urbanas, habitação e equipamentos públicos, entra em colapso, provocando a partir do final dessa década uma nova forma de atendimento habitacional: a distribuição de lotes semiurbanizados sem transferência de domínio, apenas com a concessão de títulos precários de posse. Os beneficiários desse programa de distribuição acabam por reproduzir as formas de produção das periferias dos outros grandes centros por meio da autoconstrução da moradia.

Dessa forma, o moderno se coliga com o que se considera atrasado mais precário, quando observado que a existência de projeto urbanístico com execução parcial das infra-estruturas pelo Estado, não representa garantia de condições adequadas de saneamento. Além disso, esse mesmo agente implementa formas deficientes de estruturas de transporte, e, como expresso anteriormente, a ação direta do Estado se aproxima com o que é considerado em outras cidades como inação do Estado, reproduzindo a maneira precária presente em todas os centros urbanos brasileiros, pólos atratores de migração. Nem mesmo a propriedade é garantida a esses beneficiários, que amargam anos até a regularização fundiária e imobiliária das terras parceladas pelo Estado, tendo apenas, como documento um título precário de permissão de uso.

No entendimento de Sampaio Jr ao se referir ao pensamento de Caio Prado Jr.

"a idéia de que a associação com o capital internacional minaria o processo de formação de um sistema econômico nacional, desencadeando uma tendência à reconstrução do antigo sistema colonial - deve ser resgatada como uma contribuição fundamental para a compreensão do verdadeiro caráter da industrialização brasileira e da natureza da crise atual. ${ }^{\text {199 }}$

${ }^{199}$ lbid. p 427 
Já para Florestan Fernandes a formação da sociedade brasileira está associada a dois fatores, a emergência e a evolução do processo de modernização como modo de vida, buscando construir as condições econômicas, socioculturais e políticas que permitem à sociedade controlar seu destino.

E ainda, essa formação é vista como resultado de três ciclos: a emancipação nacional (nação emergente como projeto de Estado nacional); a revolução burguesa (consolidação do capitalismo como modo de produção); e a revolução operária (superação das formas de opressão burguesa). O planejamento urbano modernista, que estava a serviço do Estado na execução da capital, comungava dessas idéias. Os principais arquitetos desse episódio comungavam de posições próximas quanto à necessidade dos ciclos, um comunista e o outro humanista. Mas, acreditavam que os ciclos seriam resolvidos em concomitância, pois era parte do discurso do nacional-desenvolvimentismo, não necessariamente o de Juscelino, mas de autores como Ignácio Rangel e outros do ISEB.

A capital federal seria a contribuição dos arquitetos e urbanistas para concretizar os três ciclos, pois, na visão desses, marcava a emancipação nacional, afinal o país começaria a se ver a partir de seu interior com um novo projeto de Estado, consolidando rapidamente a expansão dos mercados consumidores internos e transformando a sociedade rural e arcaica na sociedade urbana e moderna, ou seja, consolidando o capitalismo. Um ponto de divergência entre o comunista Oscar Niemeyer e o humanista Lúcio Costa estava no terceiro ciclo. Um via a possibilidade de uma revolução operária aos moldes dos países do leste europeu, o outro via a possibilidade de um Estado de Bem-Estar Social. Os dois pelo menos trabalhavam com o mesmo instrumental de pensamento: o modernismo.

Nos três ciclos que o país deveria superar, Florestan Fernandes detecta a dificuldade da sociedade brasileira empreender essa tarefa, pois, não consegue dar força aos processos revolucionários que impulsionam a formação da civilização brasileira. Para Florestan segundo Sampaio Jr, a emancipação nacional e a revolução burguesa avançaram por uma vertente onde aparentemente havia menor resistência, de forma que deviam se apresentar como "processos estruturais destituídos de conteúdo econômico, social, político e cultural que pudesse comprometer os fundamentos do capitalismo dependente"200. Essa condição obrigava a uma redução da força da intervenção ao mínimo necessário ao atendimento da conjuntura histórica, já que não podia caracterizar ruptura.

A revolução operária por sua vez custou a emergir, devido ao atraso industrial e à formação

${ }^{200}$ SAMPAIO JR, 1999 p. 430 
do proletariado como classe social, que só podemos realmente identificar como corpo capaz de influir nos processos, a partir do final da década de 70 , ou seja após o surto de industrialização. A proletarização do colono não contribuiu com a devida rapidez que se imaginava. É importante ressaltar que o impacto da globalização sobre o mundo do trabalho, afetou profundamente o proletariado que não havia ainda se constituído, solidamente enquanto classe social ainda mais se marcarmos que sua história no Brasil é recentíssima.

Sampaio Jr chama a atenção para uma crença de Florestan, que identifica que "as reações inconformistas contra o subdesenvolvimento teriam adquirido vitalidade suficiente para gerar uma forte tendência à autonomização, porém não há vitalidade necessária para permitir que o processo de integração nacional fosse levado até o fim"201. Daí uma situação aonde o "atraso" e o "moderno" se conciliariam, resultado da consolidação conservadora do poder burguês ocorrida entre a República Velha e a segunda metade da década de 60.

As formas de conciliação do atrasado e do moderno pelo projeto nacionaldesenvolvimentista estão marcadas em uma interpretação presente no primeiro capítulo, que demonstra essa tese a partir de outra leitura, a partir do ideário do Estado como ator principal para o desenvolvimento econômico e como investidor em setores e territórios em substituição ao setor privado. Além disso, este mesmo Estado que se pretendia moderno devia garantir a permanência de estruturas seculares de exploração presentes, por exemplo, nas relações de produção do setor agrícola, numa expansão do mercado interno a ser realizada pelo Estado, mas controlada por uma elite de bases latifundiárias, sendo um dos fatores que limita a realização econômica e social de um processo de industrialização. Por conseguinte, uma integração nacional é limitada a setores e territórios de interesse desse grupo.

Ricardo Faret, ao fazer uma análise quanto às regiões onde são executados os investimentos, observa que o discurso do nacional-desenvolvimentismo se desarticula da prática dos investimentos estatais em todo o período das décadas de 60 e 70, pois, ainda são investimentos marcadamente direcionados às regiões já industrializadas do sudeste. Brasília aparece, então, como uma nuvem passageira de investimentos no centro do país então, à exceção dos investimentos rodoviários, que mesmo assim permaneciam aquém.

Na leitura de Sampaio Jr, sob a ótica de Florestan, é no momento de definir suas alianças estratégicas, que a burguesia tomou uma decisão realista e pragmática, jogando todas as suas energias na negociação dos termos da dependência, de forma a criar uma 
possibilidade que visava desvincular a aceleração do desenvolvimento capitalista do processo de integração nacional, o que "levou as burguesias brasileiras a optarem por uma aliança estratégica com o capital internacional e com as nações hegemônicas, em detrimento da formação de mecanismos de solidariedade orgânica com as classes populares." 202

É importante entender algo sobre a revolução burguesa, para a compreensão da interpretação de Florestan, que, segundo ele próprio, apesar da manutenção dupla de subordinação externa e a assimetria da sociedade colonial, foi completada mesmo que de forma canhestra e limitada tendo em vista que foi capaz de criar um mercado interno considerável, mas, restrito a uma parcela determinada da população. O regime militar é elemento que se soma à fórmula, e que possibilita que uma parcela do poder seja adquirida pela burguesia, e também, promove os ajustes necessários para a internalização das estruturas e dinâmicas fundamentais do capitalismo monopolista.

Esta mesma burguesia, comprometida com a manutenção deste atraso, paradoxalmente consegue se apresentar à sociedade como a protagonista das mudanças, o que permitiu a adaptação da economia e da sociedade às exigência de um capitalismo monopolista. Ela ganha poder de barganha no mercado externo, como também assume a responsabilidade de acelerar os processos ditos modernizantes, submetendo os segmentos mais atrasados aos modernos.

Assim, mesmo com o industrialização ocorrendo de forma massiva "o capitalismo continuou sendo um processo induzido de fora para dentro, incompatível com a reprodução de mecanismos de solidariedade orgânica entre classes sociais." ${ }^{203}$.

Somado a isto, a burguesia fecha o processo político a um circulo pequeno, deslocando as questões nacionais e democráticas da vida política, legitimando um Estado "comprometido com a defesa de interesses mesquinhos e particulares da plutocracia brasileira. É o poder burguês como uma contra-revolução permanente" ${ }^{204}$. O excedente de poder era essencial para a sobrevivência dessa burguesia, aliada importante de um mercado externo.

Aqui, há algumas considerações interessantes de serem feitas sobre a própria consolidação da capital federal e seu efeito e imagem pós-inauguração. É no regime militar que se

\footnotetext{
202 SAMPAIO JR, 1999, p.432

${ }^{203}$ Idem p. 435

204 Ibid, p 432
} 
consolida a cidade, como aglomerado urbano, e como capital, é sobre essa égide que Brasília e o planejamento moderno a ela vinculado foram muitas vezes interpretados, marcava-se nessa crítica o distanciamento seguro que a capital oferecia ao regime militar dos conflitos urbanos e o próprio desenho da cidade que não propiciaria condições para as ações de contra-revolução em primeira análise. A essa critica faz-se uma ponderação, é verdade que a transferência da capital para o interior do país se alinhava ao pensamento geopolítico muito representativo do pensamento militar, no qual a segurança do centro do poder é essencial, e aí se filiaram as críticas sobre o poder distante do povo. Contudo, essa posição não encontra sustentação histórica no Brasil, pois Getúlio Vargas em sua primeira estada no governo comandou um regime ditatorial, entre 1930 e 1945, residindo na capital do Rio de Janeiro.

Outra crítica comum se faz ao projeto urbanístico de Brasília e se insere numa visão que concilia a vivencia do autor do plano às formas concretas de segregação espacial resultante do planejamento urbano implementado. A essa crítica é possível tecer mais comentários, o que será feito mais adiante.

Nessa conjuntura histórica do regime militar, Florestan Fernandes relembra que, o crescimento econômico foi um fator de estabilidade da ordem que, associado à expansão dos empregos, criou um mecanismo de mobilidade social, principalmente, junto às classes populares. Surge como conseqüência o mito do crescimento como solução dos problemas do país.

Esse fato pode ser observado na capital federal nos primeiros anos da década de 70 , como pode verificar Suely Gonzales ${ }^{205}$. Nesse período de consolidação do aglomerado urbano do Distrito Federal, a mobilidade social ascendente contribuiu com dois aspectos importantes, o primeiro ao reforçar a capital como pólo de atração de migração e marcar a forma com que o planejamento moderno adotado respondia a essa questão. Neste último, caso na forma de segregação urbana adotada para atendimento habitacional, com a criação de assentamentos nas cidades-satélites. Esse contingente, por não encontrar condições de moradia adequada, usou o expediente de ocupação de terras públicas, executando, como denominada pelo governo local, a "invasão". Uma estratégia adotada por esses migrantes para garantir condições mínimas de sobrevivência.

${ }^{205}$ GONZALES, Suely Franco Netto. As formas concretas da segregação residencial em Brasília in: PAVIANI, Aldo (org). Brasília, ideologia e realidade: Espaço urbano em questão. São Paulo: Projeto, 1981. $258 \mathrm{p}$ 
Mas, com a evolução do sistema capitalista para uma nova fase de globalização, Florestan Fernandes percebeu a tendência a uma destruição dos suportes externos do Estado autocrático burguês, podendo então deflagrar a reversão neocolonial, já que segundo ele:

"Ao contrário do ciclo anterior, não há necessidade de formação de uma infra-estrutura específica. A reprodução do sistema de produção encerra-se no exterior. O país torna-se mais periférico, combina dependência com múltiplas malhas coloniais e sucumbe nas garras regressivas, das quais resulta o atual pós-moderno."206

O novo contexto reduz a autonomia relativa da burguesia brasileira, o que leva a uma diminuição na sua capacidade de negociação dos termos de sua inserção na economia mundial e de defesa dos espaços por ela controlados. Ou seja, esta possui mais margem de manobra para negociar os termos de sua dependência.

A capacidade de barganha da burguesia vai-se desmontando já que,

“(...) em primeiro lugar, as exigências para participar da globalização - (...) deixam o país totalmente vulnerável às exigências e às chantagens do grande capital financeiro internacional. Em segundo lugar, o colapso da União Soviética e a crise do movimento socialista, ao afastarem a ameaça imediata de projetos políticos alternativos que pudessem questionar a absoluta hegemonia do capitalismo e a franquearem espaço para que os Estados Unidos pudessem dar livre curso à sua vocação imperial, deixavam as economias periféricas ao sabor do arbítrio de uma ordem internacional arbitrária e

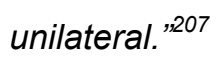

A desarticulação do mecanismo de mobilidade social desenvolvido no processo de industrialização por substituição de importação, também contribui para este processo de reversão neocolonial.

A mudança é de uma rapidez tão impressionante que a burguesia passa de sócia privilegiada, a mera intermediária comercial do grande capital financeiro, o controlador de todo o processo de globalização. Além do desmonte da estrutura de dominação burguesa, alimenta outro processo de reestruturação e precarização do trabalho, liquidando a única esperança que esse capitalismo dependente dá às classes dominadas, que é a expectativa de mobilidade social.

No caso de Brasília, a sua pretensa burguesia é dependente da máquina estatal, e o papel

\footnotetext{
${ }^{206}$ FERNADES, Florestan. O eclipse do trabalho. Folha de São Paulo, 26/06/1995

207 SAMPAIO JR, 1995, p 435
} 
da classe dominante é exercido pelo corpo burocrático, pelo grupo que compõe os altoescalões do governo, pelos parlamentares e juizes, na forma da elite estatal. São eles que interferem drasticamente na evolução da cidade, espaço da União. A mobilidade social estava então na capacidade de investimento direto do Estado no espaço da capital, o que concretamente representava, nas primeiras décadas, numa consolidação do espaço físico por meio de investimentos diretos na execução de edifícios destinados a sede da administração federal e àqueles destinados ao corpo burocrático do Estado. Não é a toa que o empreendedor, incorporador imobiliário privado só começa a ser observado na capital no inicio dos anos 70. E aí começam a realizar ganhos mais diretos pelo volume investido no setor da construção civil e pela condição do grande rebaixamento de salários e grande oferta de trabalhadores, migrantes.

Veja que o processo econômico da capital se sustenta num setor onde existe a extração direta da acumulação primitiva, a mais pura realização do capital pela exploração da mãode-obra. E ainda, o planejamento modernista, que tem em sua formulação a subvenção à moradia, concentra esforços para realizar, num primeiro momento, esse papel para os funcionários do Estado e, só mais tarde, para o excedente populacional por meio das erradicações de invasões.

$\mathrm{Na}$ interpretação de Celso Furtado, a formação econômica do Brasil é o próprio processo histórico. Nas palavras de Sampaio, "de constituição das bases técnicas, do substrato social, da matriz espacial, dos 'centros internos de decisão"'208 e do projeto ideológico que compõem um sistema econômico nacional. O eixo de sua interpretação articula-se em torno da relação contraditória entre posição periférica do país no sistema capitalista e o avanço do processo de industrialização - a coluna vertebral de um sistema econômico.

A abordagem de Furtado contribui com o entendimento do papel da ideologia do nacionaldesenvolvimentismo e secundariamente para perceber o papel da capital com seu planejamento modernista deslocado do lugar de origem.

Para este autor, uma transição de uma economia colonial para uma economia nacional sempre foi dificultada por não ter ocorrido de fato uma ruptura com o passado colonial, com o centro capitalista, de outra forma reafirmando a dependência. O Brasil como economia dependente, industrial e subdesenvolvida, pode ser captado em cinco aspectos:

o baixo nível econômico associado ao primitivismo da economia colonial, a uma sociedade ultra-elitista escravocrata em um território imenso, disperso e pouco

${ }^{208}$ SAMPAIO JR, 1999 p. 437 (grifo do autor) 
povoado;

o atraso na formação de um mercado interno e no aparecimento dos centros de decisão internos;

a ampliação do atraso relativo da economia brasileira, num momento em que a revolução industrial era difundida;

a eclosão tardia da industrialização;

a subordinação da industrialização por substituição de importações à lógica do processo de modernização de padrões de consumo;

Mesmo com esta subordinação, a industrialização para Furtado, possui um papel extremamente importante na formação econômica do país, ampliando as oportunidades de emprego, contribuindo para viabilizar um modelo brasileiro e cristalizando uma unidade nacional.

A visão desse autor, obviamente, é a que mais se coaduna com o ideário do nacionaldesenvolvimentismo, já que teve influência direta na formulação dos princípios que geraram o Plano de Metas de Juscelino Kubitschek com seu trabalho a frente do Grupo Misto CEPAL - BNDE, como afirma Francisco de Oliveira.

Dentro do aspecto geral acima colocado, segundo Sampaio Jr, Furtado vê os efeitos desestruturantes do processo de transnacionalização do capitalismo sobre a economia brasileira, como elemento que modifica radicalmente "a relação entre o processo de modernização dos padrões de consumo e formação econômica do Brasil", o que interrompe um ciclo de expansão das forças produtivas, já que havia uma desarticulação do processo de industrialização por substituição de importações.

A incapacidade do Estado em impor limites à mobilidade do capital leva à ruptura das sinergias econômicas e políticas coerentes com os regimes de acumulação de capital dos sistemas nacionais, permitindo o avanço da internacionalização dos circuitos econômicos financeiros e tecnológicos, de tal modo que as atividades permanentes do Estado acabam se restringindo apenas às áreas sociais e culturais.

Interrompe-se aqui o raciocínio para uma contribuição ao conjunto de reflexões sobre o papel do planejamento urbano modernista em Brasília e o que ele acabou por representar. Mesmo que aceita essa interpretação quanto às áreas de permanente atividade do Estado, a social e a cultural, na constituição da estrutura do espaço físico, aparentemente elas não se concretizam dada a agudeza das desigualdades geradas pela sociedade brasileira. Aparentemente os investimentos sociais e culturais são residuais a economia urbana.

Contudo, essa interpretação marca e fortalece uma visão do planejamento urbano 
modernista, herança do Estado de Bem-Estar-Social europeu, o qual as autoridades e os técnicos governamentais abraçam como ideal de construção da nova capital federal. Uma idéia onde esse planejamento urbano se destina à transformação social e cultural da sociedade por meio de investimentos no espaço urbano, o que levou o Estado a investir entre 1957 e 1960, algo similar a 2,3\% do PIB de 1960209, numa única cidade, o que demonstra uma dificuldade desse modelo ser reprodutível ao longo dos períodos posteriores, mesmo que admitido que os maiores investimentos são aqueles executados em infra-estrutura urbana inicial e que, observando Brasília, não é o caso, pois, optou-se por polinuclear o tecido urbano com a criação das cidades-satélites. E, se colocado como modelo nacional de atuação governamental de política urbana, acaba por parecer ainda mais improvável de ser reproduzido por muito tempo, guardadas todas as considerações quanto à realidade de cada um dos centros urbanos.

Então, se existe uma incapacidade estatal em regular a mobilidade do capital e, ainda, resta-lhe apenas parcos recursos e atividades as quais pode efetivamente atuar permanentemente, para Celso Furtado, o rumo traçado a partir disso, tende a agravar a distância entre as economias centrais das periféricas, o que constituiria na "nova dependência", dificultando de sobremaneira a capacidade de uma economia periférica determinar a direção das transformações econômicas capitalistas de acordo com as necessidades e desejos da sociedade nacional. Isso resultaria em uma contradição aguda entre dependência e desenvolvimento nacional.

Nesta nova dependência, a dívida externa e a integração cada vez maior no sistema monetário internacional são armadilhas que reforçam a condição subalterna dependente, pois deixam a economia nacional extremamente vulnerável às pressões externas, obrigando a um ajustamento interno, imposto pelas instituições financeiras internacionais. Torna-se clara então a posição da economia na hierarquia da divisão internacional do trabalho, onde se abre mão da plena realização do mercado interno como centro dinâmico da economia, interpretação que é consonante entre os três autores.

No caso de Brasília observa-se a ocorrência de um ajustamento urbano quanto à capacidade de investimento direto, refreando algumas ferramentas chaves à época da construção. A mais importante é a Companhia Urbanizadora da Nova Capital - NOVACAP, que perde suas funções privilegiadas de acesso a empréstimos internacionais com aval

\footnotetext{
209 Segundo Celso Lafer. ver em DISTRITO FEDERAL (BRASIL). Modelo de gestão estratégica do território do Distrito Federal. Brasília: Metroquattro Arquitetura Tecnologia, 2004, p. 45
} 
direto do Estado e, além disso, suas atribuições são paulatinamente diminuídas, como a comercialização de terras e imóveis urbanos, que fica a cargo da Companhia Imobiliária de Brasília - TERRACAP, e a regulação e controle do estoque de glebas rurais arrendadas, que são transferidas para Fundação Zoobotância. Por meio de uma descentralização de poderes e extinção de outros e que a empresa industrial de JK, a NOVACAP, passa a ser uma empresa estatal prestadora de serviços de zeladoria para o Governo do Distrito Federal.

Sampaio Jr ainda deixa claro na sua leitura de Furtado que existe uma "sacralização do mercado como princípio organizador da sociedade" que "paralisa os centros nacionais de decisão, questionando a própria noção de espaço econômico" ${ }^{210}$, incentivado pela intensificação de valores do centro que exacerba uma dependência também cultural. A própria reificação dos padrões de consumo importados das economias centrais.

É importante citar Furtado neste ponto

"O que está em jogo é mais do que um problema de desmistificação ideológica. Temos que interrogar-nos se os povos da periferia vão desempenhar um papel central na construção da própria história, ou se permanecerão como espectadores, enquanto o processo de transnacionalização define o lugar que a cada um cabe ocupar na imensa engrenagem que promete ser a economia globalizada no futuro. "211

O Brasil, assim, muito vulnerável nesse novo contexto, dada a incapacidade da indústria nacional de enfrentar a concorrência internacional, não consegue se desprender desta dependência, seja pela pequena disposição ou pela impossibilidade material em modernizar o parque industrial, já que seria necessário um esforço enorme de poupança para empreender esta mudança e a fórmula adotada para o desenvolvimentismo, como visto no primeiro capítulo, acabou por se basear nas "poupanças externas".

Outro ponto colocado por Furtado diz respeito ao ajuste da economia brasileira às imposições da ordem global, que ameaça o sistema produtivo, por um lado pela eliminação das indústrias de bens de capital que desarticulariam ligações estratégicas que possibilitavam que a indústria funcionasse dinamizando a economia, e por outro devido às empresas transnacionais que necessitam de especialização da economia brasileira, "em setores de baixo conteúdo tecnológico, cuja competitividade internacional depende da

\footnotetext{
${ }^{210}$ SAMPAIO JR, 1999, p. 440

${ }^{211}$ FURTADO, Celso - A Revolução Burguesa no Brasil: ensaio de interpretação sociológica. Rio de Janeiro, Zahar, 1976 , p 132
} 
superexploração da força de trabalho e da degradação do meio ambiente"212

É então na leitura que Plínio de Arruda Sampaio Júnior faz desses três pensadores que chega a um ponto importante de interpretação, na qual avalia que existe uma ameaça a construção da nação. Segundo sua interpretação o "comprometimento do mercado interno como centro do crescimento" associado à maneira desarticulada em que se deu o processo de industrialização no Brasil, provocam uma tendência à desintegração do espaço econômico nacional, reforçando as formas regionais.

Compromete-se assim a integração nacional como projeto de nação inserida no desenvolvimento capitalista, o que acaba por caracterizar nossa forma de (sub)desenvolvimento.

Sampaio ainda ressalta que o imobilismo da sociedade brasileira surpreende Furtado que, atribui essa situação à herança da ditadura militar e, ainda, que a essência do "modelo brasileiro", consiste em subordinar o estilo de crescimento às exigências das empresas transnacionais. A perda do controle do Estado sobre os mecanismos de apropriação e produção de excedentes sociais, aprofundada pela elevação exponencial da dívida externa - resultado do "milagre econômico" e o II PND - faz parte da análise de Furtado, que afirma que se estava "hipotecando o futuro do país". O resultado disto pode ser verificado na crise dos anos 80.

Esse imobilismo da sociedade brasileira que Furtado se refere se harmoniza com Raymundo Faoro quanto à inação que é apresentada mais adiante, não quanto os motivos mas quanto ao resultado.

A urgência de Furtado quanto à superação desse estado de construção interrompida está na reformulação das estruturas e na resistência à dependência.

"O desafio que se coloca à presente geração é, portanto duplo: o de reformar as estruturas anacrônicas que pesam sobre a sociedade e comprometem sua estabilidade, e o de resistir às forças que operam no sentido de desarticulação de nosso sistema econômico, ameaçando a unidade nacional. ${ }^{, 213}$

Segundo Sampaio Jr há uma convergência no pensamento dos três estudiosos, de que a continuidade da dependência externa provocaria uma perigosa "reversão neocolonial", o que indica a urgência na ruptura dessa situação atual, sendo necessária a superação do caráter

\footnotetext{
${ }^{212}$ SAMPAIO JR, 1999 p. 442

${ }^{213}$ FURTADO, Celso - A construção interrompida. Rio de Janeiro, Paz e Terra, 1992, pg 13
} 
dependente do sistema econômico, da natureza extremamente assimétrica das estruturas sociais e do pesado fardo do colonialismo cultural.

Pode-se então dizer, em uma breve constatação sobre como esse processo econômicosocial brasileiro, estudado por Plínio de Arruda Sampaio Júnior, que se utilizou das interpretações de Caio Prado Júnior, Florestan Fernandes e Celso Furtado, afetou a realidade urbana brasileira, de forma a gerar o que Ferreira denomina como "o padrão urbano imposto pela forte industrialização e o milagre econômico" que "só fizeram, portanto, exacerbar a matriz desigual das nossas cidades, herdada da colônia". Ainda:

"A direta ligação entre crescimento sem distribuição e a expansão do capitalismo mundial explica por que o que descrevemos acima tornou-se o padrão do subdesenvolvimento não somente na Brasil, mas, em todo o mundo. O chamado 'desenvolvimento desigual e combinado' do capitalismo, muito bem descrito, no caso brasileiro, pelos grandes interpretes da formação econômica e social nacional, explica a semelhança dos cenários de profunda desigualdade social-urbana nas grandes cidades da periferia do capitalista mundial, a proliferação de favelas sendo a expressão de uma pobreza urbana que, como explica a urbanista Ermínia Maricato, não é mais exceção, mas sim tornou-se 'regra"”214

Contudo, existe a peculiariedade da capital federal, totalmente vinculada com a própria constituição do corpo material do Estado moderno. Ou seja, os investimentos do Estado em Brasília se vinculam em muito com o próprio investimento do Estado nele mesmo, e assim prossegue-se a análise tendo em vista a ótica do Estado.

Até esse momento a discussão foi centrada em interpretações mais voltadas a formação social e econômica brasileira, ficando a questão da própria formação do Estado nacional como resultado disso. Ainda, se pontuou situações específicas em que, se verificou possíveis similaridades entre a discussão da produção do espaço da capital e a formação nacional. O resultado parece similar com os demais centros urbanos nacionais.

As interpretações de Caio Prado Júnior, Florestan Fernandes e Celso Furtado enfatizam um período marcante na formação nacional, devido à própria crise que se impõe ao sistema capitalista mundial em 1929. Este período coincide com a ascensão de Vargas ao poder e a implantação do Estado Novo.

É sob o comando de Vargas no período que corresponde de 1930 a 1945 que a estrutura do Estado brasileiro moderno se funda, segundo Wanderley Guilherme dos Santos. Ocorre,

\footnotetext{
${ }^{214}$ FERREIRA, João Sette Whitaker. O Mito da Cidade-Global: o papel da ideologia na produção do espaço urbano. Vozes; São Paulo: Editora Unesp; Salvador: Anpur 2007.p.45 (grifos do autor)
} 
nesse período, um processo simultâneo de assentamento das bases do Estado-nação e da participação popular de forma institucionalizada, com a universalização do sufrágio, agregando ao novo processo político um segmento social até então a margem.

Para Santos, essa ação é fundamental no processo da formação nacional já que até aquele momento o Brasil carecia dos fundamentos institucionais de um Estado moderno, já que: "Para que a empresa seja bem sucedida, é necessário que a própria existência material do Estado, e não apenas jurídica, pese significativamente na vida da sociedade. Façanha da Era Vargas" ${ }^{215}$.

Brasília, pela visão do nacional-desenvolvimentismo de Juscelino Kubitschek, é o ponto de materialização do Estado moderno brasileiro desenvolvimentista. Exige-se, para a formação desse Estado, a superação das crises inerentes a todos os países que se incorporam ao mundo moderno, tendo que enfrentar a crise da integração nacional, buscando formar uma identidade coletiva e, superar a questão da participação política abrangente e a de redistribuição.

Mas houve uma peculiaridade no processo brasileiro, diferentemente dos países capitalistas avançados, onde as crises ocorreram de forma sucessiva, o que possibilitava um aprendizado sobre a forma de superação, ou seja, a superação de cada uma das crises alimenta o processo de resolução da seguinte numa pedagogia processual. Essa peculiaridade está na forma de enfretamento das crises que aqui ocorre simultaneamente, em conjunção.

$\mathrm{Na}$ verdade essa peculiaridade não é só brasileira, mas da própria condição de subdesenvolvimento. Segundo Santos, nos países subdesenvolvidos em que se rompeu com a rotina oligárquica, os obstáculos ao desenvolvimento acontecem por coligação e não por sucessão.

Raymundo Faoro também destaca essa condição de combinação, de maneira muito próxima à utilizada por Oliveira, onde a dificuldade da evolução por etapas condiciona a conjugação do moderno com o atrasado. Faoro destaca que esse pensamento também é encontrado em Leon Trotsky ao analisar as condições de superação das sociedades com baixo índice de industrialização.

Atendo-se um pouco à interpretação de Wanderley Guilherme dos Santos sobre a implementação das formas que sustentariam o novo Estado, é possível observar que essa

${ }^{215}$ SANTOS, 2006 p. 58 
combinação entre o atrasado e o moderno, presente também na leitura de Caio Prado Júnior, advêm do desejo de industrializar o país, o que exigia a recuperação das atividades econômicas capazes de prover o financiamento do projeto, e por este propósito, a agricultura de exportação, em particular o café, são parte essencial.

"O rompimento com a prática política oligárquica assinala o início da complexa trajetória da política modernizante, no Brasil, empenhada que estava a parcela da elite recémchegada ao poder em reorganizar de alto a baixo o Estado, inaugurar pontes diversificadas com a sociedade e deixar definitivamente para trás as competições políticas cujos vencedores eram antecipadamente conhecidos. $\underline{\text { A incógnita era como }}$ levar a termo uma tarefa caracteristicamente urbana, em seu impulso inicial, tendo por retaguarda uma população majoritariamente rural, com folgas, e analfabeta. Como convidar os trabalhadores urbanos à participação institucionalizada na ausência de sólidas e rotineiras organizações? De que maneira instaurar políticas de âmbito nacional sem contar com o fundamental recurso de um mercado igualmente nacional e de uma burocracia pública competente?,216

Esse modelo de desenvolvimento é extremamente contraditório, já que necessita da superação da velha oligarquia e de sustentar o modelo econômico anterior de agricultura de monocultura, e, os instrumentos de competição política implantados por Vargas representam uma mudança radical no quadro político. O voto secreto, a cabine indevassável, a justiça eleitoral e a inclusão do eleitorado feminino, são esses instrumentos. Veja, essas formas permitem a determinação do Plano de Metas por um político legitimado por esse processo iniciado na era Vargas. Como visto, a filiação quanto à origem do planejamento econômico de Juscelino é direta de Vargas.

A dimensão política dessa mudança não era de todo captada pela sociedade, pois havia aqueles que acreditavam que a manifestação política ampla consagraria a volta da oligarquia, e sendo que para os liberais era apenas a moralização da disputa política.

Outro fato significativo na mudança política diz respeito ao corpo do Estado, que para atender às necessidades do modelo que se desenhava buscou reforçar a burocracia, com Vargas esta que se torna um novo interlocutor entre a população e os executivos governamentais, legisladores e os poderes executivos

“(...) a burocracia gradativamente adquiria maior importância estratégica na medida em que a operação da máquina do Estado, de complexidade crescente, premiava em prestígio e poder, além de renda, àqueles com ela familiarizados. Era um fenômeno novo

${ }^{216}$ SANTOS, 2006 p. 21 (grifo nosso) 
a ser acrescentado aos grupos de interesse de militância visível e agressiva, aos partidos de massa e a uma elite política nascida da quase universalização do voto, heterogênea em sua origem de classe, e em elevado débito junto às populações urbanas instaladas no setor secundário-industrial da economia, a cujo favor devia o mandato. $O$ quadro de referência, aqui, são as sociedades industriais modernas. ${ }^{, 217}$

Essa percepção da importância adquirida pela burocracia é também ponto de análise de Faoro, que em concordância com Santos afirma que a questão a ser abordada é "como estão dispostas para relacionamento as esferas pública e privada"218. É também observado por Santos o aumento da burocracia pública, pode ser, ou é o principal estímulo para o aparecimento e aumento do clientelismo moderno.

Para Faoro, a indistinção entre o público e o privado, notabiliza a formação do Estado brasileiro, sendo então o patrimonialismo é sua cara.

"A comunidade política conduz, comanda, supervisiona os negócios, como negócios privados seus, na origem, como negócios públicos depois, em linhas que se demarcam gradualmente. O súdito, a sociedade, se compreendem no âmbito de um aparelhamento a explorar, a manipular, a tosquiar nos casos extremos. Dessa realidade se projeta, em florescimento natural, a forma de poder, institucionalizada num tipo de domínio: o patrimonialismo, cuja a legitimidade assenta no tradicionalismo - assim é porque sempre foi. ${ }^{, 219}$

O Estado nacional brasileiro, segundo Faoro, é resultado da forma de exploração colonial portuguesa, e que no choque com a evolução do liberalismo em conjunto com a independência nacional, não consegue responder à mudança estrutural exigida. Esse Estado busca por meio da incorporação das técnicas e racionalidades exigidas pelo sistema econômico se ajustar ao modelo internacional, sem incorporar de fato, a verdadeira mudança material exigida pelo estágio do capitalismo à época.

Um dos aspectos que influem na própria formação urbana, como já citado, é a tentativa de proletarização dos colonos sem que organizações de apoio ao trabalhador, como os sindicatos, estivessem sequer formalizadas ou legalizadas. Ferreira lembra o resultado do processo de industrialização no caso brasileiro que guarda algumas semelhanças a observada no século XIX na Europa.

\footnotetext{
${ }^{217}$ SANTOS, 2006 p. 26

${ }^{218}$ FAORO, 2001 p. 817

${ }^{219}$ idem, 2001, p. 819
} 
"A industrialização da periferia de fato recapitulou, na metade do século XX, o fenômeno da industrialização dos países desenvolvidos, que cem anos antes gerara o inferno urbano das cidades industriais européias, levando Engels a escrever seu relato seminal sobre a miserável situação urbana do proletariado em Manchester. Recapitulou-o, mas sobretudo o confundiu, por sua peculiaridade, que distinguiria os dois processos em um ponto essencial: justamente o da maciça produção de pobreza,220

A forma weberiana de análise que Faoro faz uso, a existência de um corpo autônomo (burocracia) dentro do Estado é admitida como essencial, devendo ser ele competente, racional e neutra. Mas, segundo a interpretação de Faoro, esse preceito não se adéqua completamente em uma análise da formação do Estado brasileiro. É nesse sentido que busca uma diferenciação para tratar de um corpo administrativo burocrático competente e outro que representa os interesses tradicionais.

"Há a burocracia, expressão formal do domínio racional, própria ao Estado e à empresa modernos, e o estamento burocrático, que nasce do patrimonialismo e se perpetua noutro tipo social, capaz de absorver e adotar as técnicas deste, como meras técnicas". 221

Mas diferentemente de Faoro, que vê dentro da burocracia o crescimento de um corpo corrupto, devedor de favores, patrimonialista em sua essência, Santos interpreta à luz do tempo passado e das experiências pós-Vargas, apresentando também uma quantidade extraordinária de números, estatísticas e análise minuciosas de documentos. Para este autor há uma evidente estrutura estatal montada onde se encontra uma força burocrática estabelecida. No entendimento desse trabalho foi essa força que, se tornou a interlocutora da autoridade constituída, a mantenedora do pensamento do planejamento urbano modernista ainda ativo em Brasília.

A diferença então reside em dois pontos primordiais: primeiro na importância dos ganhos sociais, dos instrumentos de competição política estabelecido por Vargas, da construção das políticas sociais, sobretudo na política e direitos trabalhistas; segundo, na própria construção material do Estado e sua intervenção como agente produtor e garantidor de bens, o que propiciou de fato a materialização de uma estrutura econômica diferente da encontrada, contando ainda com uma ação como Estado organizador, no período Vargas como ênfase, e como Estado regulador.

\footnotetext{
${ }^{220}$ FERREIRA, 2007, p. 41

${ }^{221}$ FAORO, Raymundo p.817
} 
Essas contribuições estabelecem uma diferença importante sobre o Estado brasileiro para Santos, não ignorando, nem tão pouco diminuindo a difícil tarefa de separação entre o público e privado no Brasil, mas argumenta que:

“(...) o universo da expansão e contração burocráticas é mais complexo e rico em possibilidades do que a tradicional dicotomia entre uma weberiana e neutra burocracia, ajustada a todo um sistema de comportamento racional-legal, e a anarquia de um sistema de espólios em que os postos da administração pública não estejam sujeitos a nenhum outro circuito de casualidade senão o livre-arbítrio interesseiro e corruptor de políticos interesseiros desqualificados.,222

No seu entender também, a estrutura das organizações, suas regras internas de funcionamento, suas hierarquias, sua cultura organizacional e história, não podem ser interpretadas como aspectos irrelevantes na relação entre o privado e o público e nem mesmo nas relações intra-governamentais, não se justificando a simplificação da avaliação do comportamento burocrático.

Não é pouco então perceber a importância dessas instâncias intermediárias, dessas burocracias que cristalizam os padrões de relacionamento entre o público e o privado, já que há um fisiologismo estabelecido por mediações burocráticas. Segundo Santos, existe um contingente de pessoas introduzidas na burocracia, por indicações alheias ao sistema de mérito burocrático interno e, por isso, devedora de favores. Essas pessoas que lá estão, ou são colocadas para a reiteração de costumes clientelísticos antigos e para facilitar a distribuição de benesses. Essa é uma condição para o patrimonialismo.

A criação da Companhia Urbanizadora da Nova Capital - NOVACAP - tinha como fundamento manter um distanciamento entre os interesses clientelistas e históricos presentes no Estado patrimonialista para que fosse possível consolidar a capital federal, a exemplo de uma possível burocracia neutra. Subordinada diretamente à presidência da república e com uma grande autonomia, essa empresa não era apenas composta por técnicos da burocracia tão somente, mas, sobretudo, de profissionais que são chamados a cumprir um papel na construção da nacionalidade preconizada por Kubitschek.

Essa estrutura paralela do Estado teve sua autonomia de alguma forma relativizada, seja pela capacidade de investimento limitada dada impossibilidade de desvincular totalmente sua ação de uma fórmula do autofinanciamento que não realizou sua independência, seja pela necessidade de acordos para acomodar figuras da oposição dentro de seu quadro de

\footnotetext{
${ }^{222}$ SANTOS pg 79
} 
diretores.

Ainda mais, se observada a ação de desapropriação, teve que se deparar, por um lado, com uma das formas arcaicas de manutenção do poder rural, o domínio e posse da terra, e por outro, na produção do espaço da cidade, com os colonos expulsos das atividades rurais que se tornam trabalhadores urbanos desqualificados. Na primeira relação com a regulação da terra encontrou entraves ainda irresolutos. No caso dos excluídos, a companhia obteve uma condição que lhe é favorável, o barateamento da mão-de-obra.

Outro ponto importante para o entendimento de Santos está em ressaltar a importância do funcionalismo público, que é protegido legalmente por leis de retaliação e acumpliciamento, e se torna o legítimo interlocutor entre o político e os grupos privados, descartando cada vez mais sua posição de simples intérprete. Esse é o caráter defendido para o novo modelo que se pretendia implantar em conjunto com a construção da capital federal, o qual se fundamenta no reforço de uma burocracia mais profissional, com mais direitos, protegida da condição de devedora de favores, já que seria uma burocracia baseada no mérito tecnocrático.

A idéia de Brasília no interior do país se coligava a esse tipo de pensamento, como se buscou demonstrar e o planejamento urbano desenvolvido para a capital privilegiou o atendimento a esse novo grupo que se formava. No âmbito habitacional, garantia acesso facilitado à moradia, seja por meio de financiamentos especiais para aquisição dos imóveis produzidos pelo Estado, ou mesmo, por meio de locação subsidiada de imóveis. No âmbito urbano, garantia as melhores localizações no território, aquelas próximas ao trabalho com mais infra-estrutura implantada e equipamentos urbanos, como escolas e hospitais públicos de excelente qualidade.

Essas garantias à reprodução das condições ideais de vivência para esse segmento da sociedade na cidade provocaram obviamente uma estabilidade social na burocracia estatal e, de certo, contribuiu para uma sensação de pertencimento a um grupo social, a um grupo de interesse que vê na consolidação do Estado moderno mais profissionalizado a maior bandeira. Para esse corpo representado pela burocracia, o planejamento urbano modernista de Brasília é exitoso.

Assim, indo ao encontro de Santos, há uma motivação interna à burocracia em garantir sua expansão e reprodução, que em Brasília acabou por representar o apoio irrestrito à produção do espaço para abrigá-la. Esse corpo social do Estado, esse funcionalismo apóia o crescimento da burocracia, de maneira que consolide e reforce importantes posições dentro da estrutura do Estado. 
Essa é a crença que foi muito reforçada no regime militar de $64-85$, onde a tecnocracia buscou comandar a estrutura do Estado e os postos decisórios, o que fica claro na consolidação de Brasília como capital federal. A exemplo do que foi citado por Codato e Perissinotto quando tratam do assunto se referindo a esses postos decisórios e por Miliband e Poulantzas, a nova burocracia tecnocrática busca ocupar não só postos de comando, mas, principalmente, aqueles que garantam sua reprodução.

Arrisca-se dizer que Brasília é também resultado de um ímpeto dessa expansão e reprodução da nova burocracia que vai se profissionalizando e se estruturando. E ainda mais, o planejamento urbano modernista em Brasília garantiu a esse novo grupo em ascensão, em um período determinado, condições similares ao modelo do Estado de BemEstar Social. A esse grupo, o planejamento urbano modernista foi considerado a forma adequada de enxergar os problemas urbanos durante duas décadas até o momento da crise dos anos 80, garantindo localizações adequados a seus membros, em condições muito próximas as identificadas nas cidades dos países do Estado do Bem-Estar Social europeu.

Contudo, como efeito desse planejamento foi restrito a esse grupo e a fórmula adotada mais serve a outro tipo de estrutura social, estatal e econômica que não brasileira, esse planejamento aparece como descolado. No ideário modernista do planejamento urbano as ações devem ser universais, devem atender com equidade todas as localizações e toda população, o planejamento urbano modernista de Brasília é uma associação entre o moderno do Estado do Bem-Estar Social, que foi realizado para o corpo administrativo do Estado, e, o atrasado dos parcelamentos rurais, nas formas adotadas para atendimento a população de trabalhadores migrantes, disponibilizando a ele apenas o mínimo necessário a sobrevivência e sua manutenção como exército de reserva urbano.

\section{Algumas considerações}

Não resta dúvida como apresentado nesse trabalho, ao se analisar rapidamente o projeto urbanístico de Brasília, que sua filiação vai além da Carta de Atenas e mesmo das discussões dos CIAM, passando pela vivência de Lúcio Costa na determinação das escalas e até nas alturas das edificações, muito similares a escala urbana encontrada em Paris. Também quanto à fórmula do planejamento total modernista internalizada pela autoridade local na sua atuação como agente regulador e controlador do urbano, seja na aquisição de terras com intuito do monopólio da propriedade fundiária, numa pretensão de estabelecer controle ao mercado imobiliário, ou mesmo no estabelecimento de um monopólio estatal do mercado imobiliário de parcelamento do solo, e como visto, como grande empreendedor 
imobiliário nos primeiros anos.

A hipótese que o presente trabalho buscou delinear, por meio da observação da construção do espaço urbano de Brasília, é sobre esse Estado, que se estrutura como moderno em um arcabouço arcaico, comprometido com sua própria reprodução e com a reprodução das formas de produção anteriores. A expressão se daria, como Francisco de Oliveira ensaia em sua Crítica à Razão Dualista e em O Ornitorrinco, uma solução esdrúxula de moderno atraso.

Para realizar as transformações necessárias à instituição do Estado moderno, Vargas necessita preservar a estrutura colonial rural, que subsidia a nova infra-estrutura industrial, e para isso, não interfere no rural. Não cria condições de atuação do Estado, por exemplo, na política de terras, não institui instrumentos de aquisição de terras pelo Estado mais dinâmico, contribuindo para reforçar a persistência dos donos da terra em suas relações econômicas e sociais no interior. Não interfere diretamente nas relações, portanto entre Estado, proprietários de terras e trabalhadores rurais. Entretanto, como afirma Santos, se insere no mundo do interior com seus agentes.

Apesar de se tornar mais presente no interior, o Estado não interfere inicialmente no que dá alicerce às relações de produção do mundo rural, não interfere no controle de terras. Age como um novo ator, que aos poucos ganha força. Claramente é uma postura importante, mas não transformadora no sentido revolucionário.

Essa mesma política é adotada por Juscelino Kubistchek, como também aponta Moreira, e uma associação aparentemente paradoxal entre o ruralismo e o desenvolvimentismo garante sua política nacional-desenvolvimentista. Não tratando também de inovações em instrumentos importantes como a desapropriação de terras e a política trabalhista do trabalhador rural, possibilitou a continuação da reprodução das condições de existência do Brasil arcaico, a reprodução das relações existentes na sociedade que imbrica o arcaico e moderno. Em sua política, acredita que estabelecendo melhores interconexões e ligações entre as regiões, entre os "Brasis" do litoral e do interior, o desenvolvimento iria dar contar de parte dessas mudanças.

E em Brasília, essa não atuação provoca duas importantes condições, que mostram como era urgente uma política de Estado para a propriedade privada rural: o entrave encontrado com a desapropriação de terras, processo que perdura até hoje, 50 anos após seu início, e; a massiva migração para Brasília, que é uma reprodução do que ocorreu em todos os grandes centros urbanos brasileiros.

Brasília então é caso quase que laboratorial criado para reproduzir a sociedade brasileira e 
- Estado moderno iniciado por Vargas, que garantiu sob inúmeras formas e ações a sua materialidade em Brasília, estocando terras, e segregando o atendimento habitacional entre aqueles que pertencem e garantem a sua reprodução, o grupo denominado de funcionários públicos e os que vinham servir a esta estrutura material, os trabalhadores migrantes. A esses últimos, mais numerosos e mais empobrecidos, foi garantida uma posição, uma localização no Distrito Federal, às vezes mais próxima ao centro urbano ${ }^{223}$, mas freqüentemente mais afastada. A velocidade do aparecimento desses últimos foi fenômeno brutal em Brasília, e não há como negar que sua escala foi impressionante durante os primeiros anos da construção.

O intuito desse trabalho não foi excluir Brasília do quadro urbano nacional, mas sim inseri-la como uma forma concreta da política urbana nacional dos últimos 50 anos, tendo em vista sua peculiaridade. O ideário de planejamento urbano a que se filiava, aquele que estava expresso nos CIAM, na Carta de Atenas, e em outras teorias ${ }^{224}$, onde o subúrbio era indesejado, foi ignorado já na pré-ocupação do Distrito Federal com a criação de Taguatinga em 1958. Uma dicotomia entre centro e periferia é presente, resultado de um fator considerado contingente, uma migração acima do imaginado. Num discurso competente dos organismos de planejamento local, os resultados do planejamento modernista foi mais contingente que diligente.

O interessante na construção dessa hipótese é que a migração é causada pelo discurso desenvolvimentista para a construção de uma nacionalidade, de Estado moderno e um desenvolvimento equânime, no qual Brasília, segundo JK, era meta-síntese, mas a migração para fixação na região na escala ocorrida não fazia parte desse discurso. De materialidade de um ideário de nacional-desenvolvimentismo, Brasília se torna um objeto que expõe a ideologia criada, que excluía da equação o trabalhador, o operário, e sua inserção nessa matemática ocorre adjacente à meta.

${ }^{223}$ Como pode ser observado na coleta de dados e nas próprias políticas da SHIS e NOVACAP, existiu produção habitacional no Plano Piloto e Cruzeiro, para atendimento mais generalizado, mas não há como comparar a proporção entre demanda e oferta aos não funcionários públicos, que eram como "herdeiros naturais" das melhores localizações do Distrito Federal. As estruturas federais e locais do Estado tratavam os trabalhadores rurais, transformados em urbanos pela migração, pela necessidade e busca de melhores condições das encontradas no campo como exceções e por isso fora do planejamento da cidade.

${ }^{224}$ Como foi destacado por Carpintero, Leitão, Fisher, que existem outras vertentes teóricas que influenciaram o projeto, além de outros autores ainda anominos. 
É certo, como se afirma, que a escala de migração de Brasília foi surpreendente, as experiências anteriores de construção de capitais, Goiânia e Belo Horizonte, não davam conta dessa dimensão. Mas Brasília tinha que ser a expressão da nacionalidade ${ }^{225}$, a "capital da esperança", como André Malraux a apelidou, a capital para todos os brasileiros. A força da idéia é comprovada com essa massiva migração, ela não dá conta de toda a realidade social brasileira, e por isso torna-se ideologia pura.

$\mathrm{Na}$ capital federal a nação que buscava desenvolvimento, diminuição das desigualdades regionais, e mais investimentos fora dos antigos centros, se reconheceu na expressão que Francisco de Oliveira cunhou, se reconheceu como um Ornitorrinco, onde as técnicas mais modernas de planejamento urbano - grande domínio fundiário, pré-fabricação da construção, novas técnicas construtivas - conviveram com as chamadas "invasões" de áreas públicas pelos trabalhadores e migrantes, e construções precárias realizadas em esquema de autoconstrução com os resíduos das grandes obras da capital.

A evolução que segue pós-inauguração também não dá conta de resolver toda essa forma e para manter a idéia, a ideologia viva, preserva-se o que se considera original, o Plano Piloto de Lúcio Costa, que na verdade, não é o verdadeiro de 1957, mas aquele que foi se construindo no decorrer dos anos anteriores a 1960 e também posterior a ele.

A preservação do Plano Piloto nada mais é que uma idiossincrasia de uma visão de nação moderna da primeira metade do século XX. Tem-se a noção da importância do tombamento do Plano Piloto em suas escalas, e o que ela representa como modelo de urbanização, mas, o que esse trabalho pretende é uma postura critica ao processo de constituição do aglomerado urbano de Brasília, processo esse comandado pelo Estado, que buscou garantir, antes de qualquer coisa, a reprodução de seu espaço, e não de um espaço social mais equânime. Ou melhor, reproduziu o processo de formação urbana brasileira, onde camadas de maior renda ocupam as localizações mais bem servidas de infra-estrutura.

O mais surpreendente é que essa camada social está mais para um grupo de interesses representado pelos funcionários do Estado, do que necessariamente as camadas de maior renda. Se essas são superpostas ecomicamente, o que de fato ocorre, não o são em sua característica social do trabalho e interesses quanto ao Estado, por exemplo. Agentes públicos formam um grupo a parte com sua própria elite, que por vezes se associa à elite

\footnotetext{
${ }^{225}$ ver Moreira, Vânia Maria Oliveira, Juscelino Kubitschek de Corbusier, Roland entre outros diversos autores.
} 
capitalista na defesa de interesses comuns, como afirma Poulantzas ${ }^{226}$.

Não é uma posição contraria ao tombamento que se pretende definir neste trabalho, mas sim uma crítica ao processo de formação do espaço, tendo em vista os condicionantes que o Estado se impõe e que foram cruciais na constituição do urbano no Distrito Federal. As escalas tombadas em Brasília representam um marco importante na urbanização e no planejamento urbano brasileiro e demonstram uma capacidade enorme de mobilização social frente a uma idéia de nacionalidade, mas infelizmente, como diria Roberto Schwartz, se configurou como uma idéia fora do lugar, uma idéia irreprodutível em sua escala, já que só foi possível com a transferência da sede de um Estado nacional.

Obviamente, pós Brasília, houve experiência com certa semelhança, Palmas capital do estado de Tocantis, entretanto, as comparações quanto à magnitude e sua influência no contexto de estruturação da nação se faz a reboque de Brasília. Trabalhos interessantes e de extrema importância sobre o tema vêm sendo desenvolvidos, num esforço de entender o que representou Palmas para o contexto nacional, contudo, sem sombra de dúvida a transferência da capital federal e todos os fatos econômicos e políticos que se desenrolaram nesse período marcam a nação até hoje.

Em resumo, podemos marcar que o processo de planejamento urbano modernista assumido pelo Estado brasileiro representou, no caso da nova capital federal, a própria expressão de um planejamento urbano descolado, um planejamento urbano que acaba sendo denominado nesse trabalho de moderno atraso, pois, não considerando as condições e fatores que caracterizam a formação da sociedade brasileira que, necessitava de regular as relações de trabalho rural, de instrumentos adequados e dinâmicos destinados à consolidação da propriedade privada aos moldes capitalista (o que afetou todo o processo de desapropriação de terras no caso de Brasília), de um entendimento das relações entre os agentes internos do Estado, seus funcionários, e a sociedade que veio ao planalto central para construir o espaço físico para os aparelhos estatais, segregou membros da sociedade e contribuiu para a reprodução e o aprofundamento das desigualdades dando formato final ao ornitorrinco urbano.

${ }^{226}$ POULANTZAS, Nicos - Estado, socialismo.. 


\section{BIBLIOGRAFIA}

ALBUQUERQUE, Lucídio Guimarães. Considerações sobre Estrutura Fundiária e Uso do Solo no Distrito Federal. Brasília: Mimeo, 1994

ALTHUSSER, Louis. Aparelhos Ideológicos de Estado: notas sobre os aparelhos ideológicos de Estado. tradução: Walter José Evangelista e Maria Viveiros de Castro, introdução de José Augusto Guilhon Albuquerque. Rio de Janeiro: Edições Graal, 2a edição, 1985.

ARANTES, O.;VAINER, C.;MARICATO, E. A cidade do pensamento único. Desmanchando consensos. Petrópolis: Vozes, 2000.

BENEVOLO, Leornado. História da Arquitetura Moderna. São Paulo: Editora Perspectiva, $3^{a}$ edição, 1994.

BICCA, Paulo. Brasília, mitos e realidade in: PAVIANI, Aldo (org). Brasília, ideologia e realidade: Espaço urbano em questão. São Paulo: Projeto, 1981. 258 p.

BOBBIO, Norberto, MATTEUCCI, Nicola e PASQUINO, Gianfranco. Dicionário de Política. tradução: Carmem C. Varriale et al.; . Brasília: Editora Universidade de Brasília, $12^{\mathrm{a}}$ edição, 2000.

BONDUKI, Nabil Georges. Origens da habitação social no Brasil: Arquitetura moderna, lei de inquilinato e difusão da casa própria. 2. ed. São Paulo: Estac Liberdade, 1999. 342 p.

BRASIL/PRESIDÊNCIA/SERVIÇO DE DOCUMENTAÇÃO. Antecedentes históricos: 1549 1960, tomo III. Rio de janeiro: Impressa Oficial, 1960.

CARDOSO, Miriam Limoeiro. Ideologia do desenvolvimento - Brasil JK - JQ. Rio de Janeiro: Paz e Terra, 1977

CARNOY, Martin. Estado e Teoria Política, 12ª edição - Campinas: Papirus, 2006

CARPINTERO, Antonio Carlos Cabral. Brasília: Pratica e teoria urbanística no Brasil, 19561998. São Paulo, 1998. 257f. Tese (doutorado) - Universidade de São Paulo, Faculdade de Arquitetura e Urbanismo

CAYGILL, Howard. Dicionário de Kant. tradução: Alvário Cabral; revisão técnica, Valério Rohden. São Paulo: Jorge Zahar Editora, 2000

CHAUI, Marilena. O que é ideologia. São Paulo: Editora Brasiliense, $4^{a}$ reimpressão da $2^{a}$ edição, 2004. 
.Cultura e democracia: o discurso competente e outras falas $-11^{\text {a }}$ ed revista e ampliada - São Paulo: Cortez, 2006

CODATO, Adriano Nervo e PERISSINOTTO, Renato Monseff. O Estado como instituição. Uma leitura das Obras Históricas de Marx. In: Crítica Marxista n. ${ }^{13}$. São Paulo: Boitempo editorial. out/2001

CODEPLAN Companhia do Desenvolvimento do Planalto Central. Sugestões para erradicação de habitações sub-humanas DF: Invasão do IAPI Vila Tenório. Brasília 1969. 1 v . Diagnóstico do Setor Habitação do Distrito Federal. Brasília: CODEPLAN, 1971. $210 \mathrm{f}$.

. Núcleos habitacionais futuros do Distrito Federal. Brasília 1972. 145 p.

ANUÁRIO ESTATÍSTICO DO DISTRITO FEDERAL. Brasília: CODEPLAN, 1977

ANUÁRIO ESTATÍSTICO DO DISTRITO FEDERAL. Brasília: CODEPLAN, 1978

ANUÁRIO ESTATÍSTICO DO DISTRITO FEDERAL. Brasília: CODEPLAN, 1979

ANUÁRIO ESTATÍSTICO DO DISTRITO FEDERAL. Brasília: CODEPLAN, 1980

ANUÁRIO ESTATÍSTICO DO DISTRITO FEDERAL. Brasília: CODEPLAN, 1981

ANUÁRIO ESTATÍSTICO DO DISTRITO FEDERAL. Brasília: CODEPLAN, 1982

ANUÁRIO ESTATÍSTICO DO DISTRITO FEDERAL. Brasília: CODEPLAN, 1983

ANUÁRIO ESTATÍSTICO DO DISTRITO FEDERAL. Brasília: CODEPLAN, 1984

ANUÁRIO ESTATÍSTICO DO DISTRITO FEDERAL. Brasília: CODEPLAN, 1985 ANUÁRIO ESTATÍSTICO DO DISTRITO FEDERAL. Brasília: CODEPLAN, 1986 
ANUÁRIO ESTATÍSTICO DO DISTRITO FEDERAL. Brasília: CODEPLAN, 1987 ANUÁRIO ESTATÍSTICO DO DISTRITO FEDERAL. Brasília: CODEPLAN, 1989 ANUÁRIO ESTATÍSTICO DO DISTRITO FEDERAL. Brasília: CODEPLAN, 1990 ANUÁRIO ESTATÍSTICO DO DISTRITO FEDERAL. Brasília: CODEPLAN, 1991 ANUÁRIO ESTATÍSTICO DO DISTRITO FEDERAL. Brasília: CODEPLAN, 1992 ANUÁRIO ESTATÍSTICO DO DISTRITO FEDERAL. Brasília: CODEPLAN, 1993 ANUÁRIO ESTATÍSTICO DO DISTRITO FEDERAL. Brasília: CODEPLAN, 1994 ANUÁRIO ESTATÍSTICO DO DISTRITO FEDERAL. Brasília: CODEPLAN, 1995 ANUÁRIO ESTATÍSTICO DO DISTRITO FEDERAL. Brasília: CODEPLAN, 1996 ANUÁRIO ESTATÍSTICO DO DISTRITO FEDERAL. Brasília: CODEPLAN, 1997 ANUÁRIO ESTATÍSTICO DO DISTRITO FEDERAL. Brasília: CODEPLAN, 1998 ANUÁRIO ESTATÍSTICO DO DISTRITO FEDERAL. Brasília: CODEPLAN, 1999 ANUÁRIO ESTATÍSTICO DO DISTRITO FEDERAL. Brasília: CODEPLAN, 2000 ANUÁRIO ESTATÍSTICO DO DISTRITO FEDERAL. Brasília: CODEPLAN, 2001 ANUÁRIO ESTATÍSTICO DO DISTRITO FEDERAL. Brasília: CODEPLAN, 2002 
ANUÁRIO ESTATÍSTICO DO DISTRITO FEDERAL. Brasília: CODEPLAN,

2003

ANUÁRIO ESTATÍSTICO DO DISTRITO FEDERAL. Brasília: CODEPLAN, 2004

ANUÁRIO ESTATÍSTICO DO DISTRITO FEDERAL. Brasília: CODEPLAN, 2005

COELHO, Marcelo Penteado. Brasília e a ideologia do desenvolvimento. 1990. 160 f. Tese (doutorado) - Universidade de Brasília

COLELA, Patrícia Maria Machado. O que não mudou na Habitação Popular: Dos cortiços a comercialização de moradias em Brasília

CORBISIER, Roland. Brasília e o desenvolvimento nacional. Rio de janeiro: Instituto Superior de Estudos Brasileiros ISEB, 1960. 74 p.

COUTINHO, Carlos Nelson. Gramsci: Um estudo sobre seu pensamento político. Rio de Janeiro: Civilização brasileira, 2003

DAHL, Robert A. Um prefácio a teoria democrática. Rio de Janeiro: Jorge Zahar Editor, 1989 Poliarquia: Participação e oposição. São Paulo: Editora universidade de

São Paulo, 2005

DISTRITO FEDERAL (BRASIL). Modelo de gestão estratégica do território do Distrito Federal. Brasília: Metroquattro Arquitetura Tecnologia, 2004. 172 p.

EAGLETON, Terry. Ideologia. São Paulo: Editora da Universidade Estadual Paulista: Editora Boitempo, 1997.

FARAH, Marta Ferreira Santos. Estado, previdência social e habitação. São Paulo, dissertação de mestrado, 1983. $189 \mathrm{f}$.

FARET, Ricardo L. O Estado, a questão territorial e as bases da implantação de Brasília in: PAVIANI, Aldo (org). Brasília, ideologia e realidade: Espaço urbano em questão. São Paulo: Projeto, 1981.

FARIAS, Darcy Dornelas de. Terras no Distrito Federal - experiências com desapropriação em Goiás (1955-1958). Dissertação de Mestrado Departamento de História da UnB. 2002 FAORO, Raymundo. Os Donos do Poder. Rio de Janeiro: Globo Editora, 3ª Edição, 2001 FERREIRA, João Sette Whitaker. O Mito da Cidade-Global: o papel da ideologia na 
produção do espaço urbano. Vozes; São Paulo: Editora Unesp; Salvador: Anpur, 2007.

FIORI, José Luis (org). Estados e Moedas no desenvolvimento das nações. Petrópolis: Editora Vozes, 1999

GARCIA, Cristiana Mendes. Construindo Brasília: a trajetória profissional de Nauro Esteves. 2004. 1-126 f. Dissertação (mestrado) - Universidade de Brasília, Faculdade de Arquitetura e Urbanismo.

GONÇALVES, Maria da Conceição Vasconcelos. Favelas Teimosas. Brasília: Thesaurus, 1998

GONZALES, Suely Franco Netto. As formas concretas da segregação residencial em Brasília in: PAVIANI, Aldo (org). Brasília, ideologia e realidade: Espaço urbano em questão. São Paulo: Projeto, 1981. 258 p.

GOUVÊA, Luiz Alberto de Campos. Brasília: A capital da segregação e do controle social: uma avaliação da ação governamental na área da habitação. Brasília, 1988. 127 f. Dissertação (mestrado) - Universidade de Brasília, Faculdade de Arquitetura e Urbanismo.

HOLSTON, James. Cidade modernista: Uma crítica de Brasília e sua utopia(a). São Paulo: Companhia das Letras, 1993. $362 \mathrm{p}$

KONDER, Leandro. A questão da Ideologia. São Paulo: Companhia das Letras, 2002 . O que é dialética. São Paulo: Editora Brasiliense, $1^{\text {a }}$ reimpressão da $27^{a}$ edição, 1995. LUKÁCS, Georg. História e Consciência de Classe: Estudos sobre a dialética marxista. Tradução: Roney Nascimento. São Paulo: Martins Fontes, 2003.

LE CORBUSIER, Pseud de Charles Edouard Jeanneret-gris. Carta de Atenas. São Paulo: HUCITEC, 1993. 1 v (Estudos urbanos; 0004)

LE CORBUSIER, Pseud de Charles Edouard Jeanneret-gris. Planejamento urbano. 3. ed. São Paulo: Perspectiva, 1984. 200 p.

LEITÃO, Francisco das Chagas. Do risco à cidade: as plantas urbanísticas de Brasília, 1957-1964 / . 2003. 243 f. Dissertação (mestrado) - Universidade de Brasília, Faculdade de Arquitetura e Urbanismo.

LOPES, Luiz Carlos. Brasília: o enigma da esfinge, a construção e os bastidores do poder. Porto Alegre: Ed. Universidade/UFRGS/ Ed. Unisinos, 1996.

MALAGUTTI, Cecília Juno. Loteamentos Clandestinos no DF: Legalizacao ou exclusao?. Brasília, 1996. 232 f. Dissertação de mestrado - Universidade de Brasília, Faculdade de 
Arquitetura e Urbanismo.

MANTEGA, Guido. A Economia Política Brasileira. São Paulo: Editora Vozes, 1984.

MARQUES, Eduardo César. Notas Críticas à Literatura sobre Estado, Políticas Estatais e Atores Políticos. In: BIB - Revista Brasileira de Informação Bibliográfica em Ciências Sociais. Rio de Janeiro: set/ 1997.

MARTINS, José de Souza. Exclusão Social e a Nova Desigualdade. São Paulo: Paulus, 1997.

MARX, Karl. O 18 Brumário e Cartas a Kugelmann. Rio de janeiro: Terra e Paz, 1997.

MARX, Karl e ENGELS, Friedirich. .Ideologia Alemã. São Paulo: Martins Fontes, 1998.

MESZÁROS, Istvan. O poder da ideologia. Tradução: Paulo Cezar Castanheira. São Paulo: Boitempo Editorial, 2004

MOREIRA, Vânia Maria Losada. Brasília: A construção da nacionalidade: um meio para muitos fins (1956-1961). Vitória: EDUFES, 1998.

NÚCLEO DE ESTUDOS REGIONAIS E URBANOS. Segregações Urbanas. Espaço \& Debate n. 45. São Paulo, 2004

OLIVEIRA, Francisco Maria Cavalcanti de. A Economia da Dependência Imperfeita. Rio de Janeiro: Editora Graal, 1977.

Crítica à Razão Dualista e o Ornitorrinco. São

Paulo: Boitempo Editorial, 2003.

PACHECO, Altamiro de Moura. Primórdios de Brasília. Goiânia: Líder, 197893 p.

PAVIANI, Aldo (Org.) Brasília: Moradia e Exclusão. Brasília, Editora Universidade de Brasília, 1996

PAVIANI, Aldo. Brasília: A Metrópole em Crise. Ensaios sobre Urbanização. Brasília, Editora Universidade de Brasília, 1989

PAVIANI, Aldo (Org.). A Conquista da Cidade: Movimentos Populares em Brasília. Brasília, Editora Universidade de Brasília, 1991.

PAVIANI, Aldo (org). Brasília, ideologia e realidade: Espaço urbano em questão. São Paulo: Projeto, 1981. $258 \mathrm{p}$.

PEREIRA, Fernando Vieira. Relação entre a política de Desenvolvimento Urbano e a política ambiental no DF: A expansão urbana na forma de condomínios(a). Brasília, 2001. 160 f. 
Dissertação de mestrado

POULANTZAS, Nicos. O Estado, o poder, o socialismo. São Paulo: Terra e Paz, 2000

RIBEIRO, Luiz César de Queiroz et all. Reestruturação nas Grandes Cidades Brasileiras: o modelo centro/periferia em questão. Rio de Janeiro, 1994.

RIBEIRO, Luiz César de Queiroz e CARDOSO, Adauto Lúcio. Planejamento urbano no Brasil: paradigmas e experiências. Espaço \& Debates n. 37. São Paulo, 1981.

ROUSSEAU, Jean-Jacques. Contrato Social. São Paulo: Martins Fontes

entre os homens. São Paulo: Martins Fontes

SAMPAIO JR, Plínio de Arruda. Impasse da formação nacional. In: FIORI, José Luiz. Moedas e Estados no desenvolvimento das nações. Petrópolis: Editora Vozes, 1999.

SANTOS, Wanderley Guilherme dos. O ex-Leviatã Brasileiro: do voto disperso ao clientelismo concentrado. Rio de Janeiro: Civilização brasileira, 2006.

SCHWARZ, Roberto. Cultura e Política. São Paulo: Terra e Paz, 2005.

SOUZA, Maria Adélia Aparecida de. A Identidade da Metrópole: a verticalização de São Paulo. São Paulo: Edusp 1994.

SCHMIDT, Benício Viero. Brasília como centro político in: PAVIANI, Aldo (org). Brasília, ideologia e realidade: Espaço urbano em questão. São Paulo: Projeto, 1981. 258 p.

SILVA, Ernesto. História de Brasília: um sonho, uma esperança, uma realidade. 4. ed. Brasília: Linha Gráfica, 1999. 391 p.

SKIDMORE, Thomas E. O Brasil visto de fora. Rio de Janeiro: Paz e Terra, 1994.

TAVARES, Joaquim Alfredo da Silva. Brasília agrícola: Sua historia. Brasília: Graf S Clara, 1995. $95 \mathrm{p}$.

TEIXEIRA, Hermes Aquino. No tempo da GEB (1956-1960), trabalho e Violência na construção de Brasília: Hermes Teixeira Brasília: Thesaurus, Brasília, 1996.

VAITSMAN, Maurício. Quanto Custou Brasília. Coleção Livro-Verdade, Rio de Janeiro: editora Posto de Serviço, 1968.

VASCONCELOS, Adirson. Cidades Satélites de Brasília(as). Brasília: Ed do Autor, 1988. $370 \mathrm{p}$.

VILLAÇA, Flávio. Espaço Intra-Urbano no Brasil. São Paulo: Studio Nobel: FAPESP: Lincoln 
Institute, 2001

WEBER, Max. Política como vocação in: Ciência e Política duas vocações. Cultrix. São Paulo, 2004

WINGE, Erika. Notas sobre o conceito de propriedade e o lote urbano: Brasília. 2007. 128 f. Dissertação (mestrado) - Universidade de Brasília, Faculdade de Arquitetura e Urbanismo. 


\section{ANEXOS}

ANEXO I - Parecer Jurídica da NOVACAP quanto aos processos de desapropriação (8 páginas - registradas pelas folhas 21 a 28) 


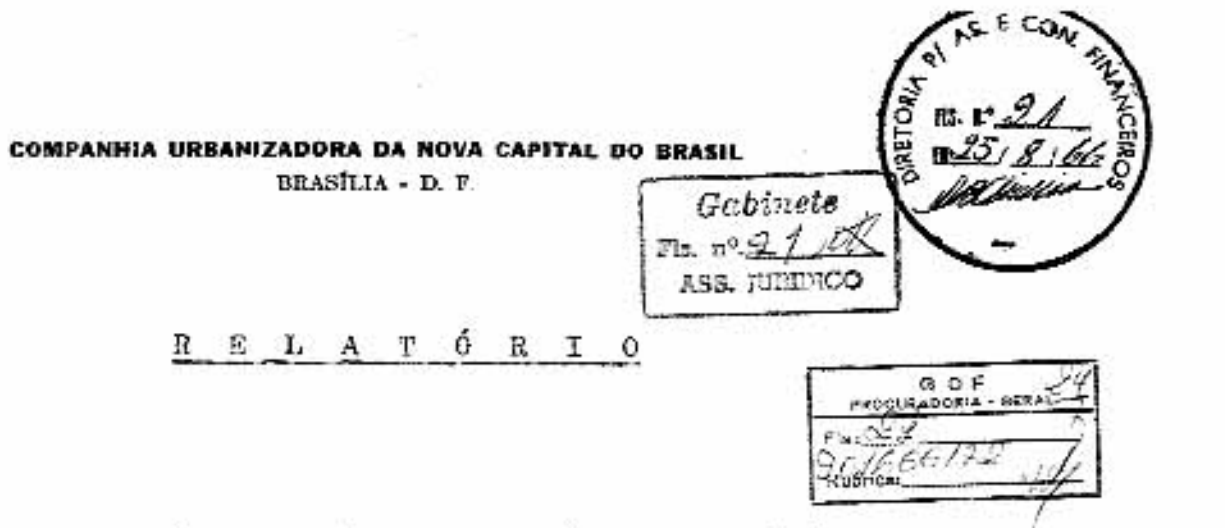

No prosente processo ( $\mathrm{n} 906.249 / 64)$, o Sr. ILDWU/ DE SOUZA LôBo propōe, ¿̇ NOVACAP, a desapropriação anigável de suas terras situatas na iazende "REPIHO DOS OLIOS DiAGU", dentro da área do Distrito Federal.

- processo, após ser devidamente instruitio foi en caminhado a P.J. para as providencias cabiveis e ests o devolve pa ro à aprcciação da Diretoria com o parecer de $1 \mathrm{~s}$, , Fo qual tece = consideraçōes oportunas e beil fumclamentadas.

A oportanidade, seja-nos permitido tecer outras = considerações sobre o assunto que, data vônia, merece upa solugāo/ rápida por se tratár de interêsse da NovacAP c de Brasilia.

De acôrdo coul a Lei $2.8 \% 4 / 56$, a NoVACAP entre = suas atribuigoes recebeu a de fazer as desaproprlaçóas inobillírias, no Distrito Federai que se fizessen necessírias a implantaço da Capital Federal e de sua administraẹão.

Há algur tenpo, o Dr. WALDIR MEUREN, Juiz de Direito da Comerca de Brasilia, ela longa e respeitável sentencra en processo desapropriatório, coneluiu que as terras situadas dentro/ da divisa do Distrito federal já pertencel a inião e por isto, dos necessária a sua desapropriaçāo pelo Poder pủblico, direta ou indi retamente.

0 meswo processo en gráu de recurso ao ser apreciado pelo Tribunal de Justiça de Brasífia, teve a sentença reformada, pelo. menos em parte é năo aceitál a conclusio. Isto em resuino, salvo engano.

Posteriormente, outros mag1strados modificaran = seus cntendimentos passando a indeferir os pedidos de desapropriagăo judicial que thes são distribuidos, porem näo inùican qual o proeesso a ser seguido para a soluģảo do problema, pois não ć líci to ignorar que a transferêncin destas terras deverí operar-se de una laneirs ou de outra, ja que existem documintos de propriedade/ transeritos, sogundo as normas legais.

Thmbein e é óbvlo que a NoVACAP näo pode Picax a. mercô de discussões intermináveis, sob pona de nảo cumprir a nissão que the foi destimada. 


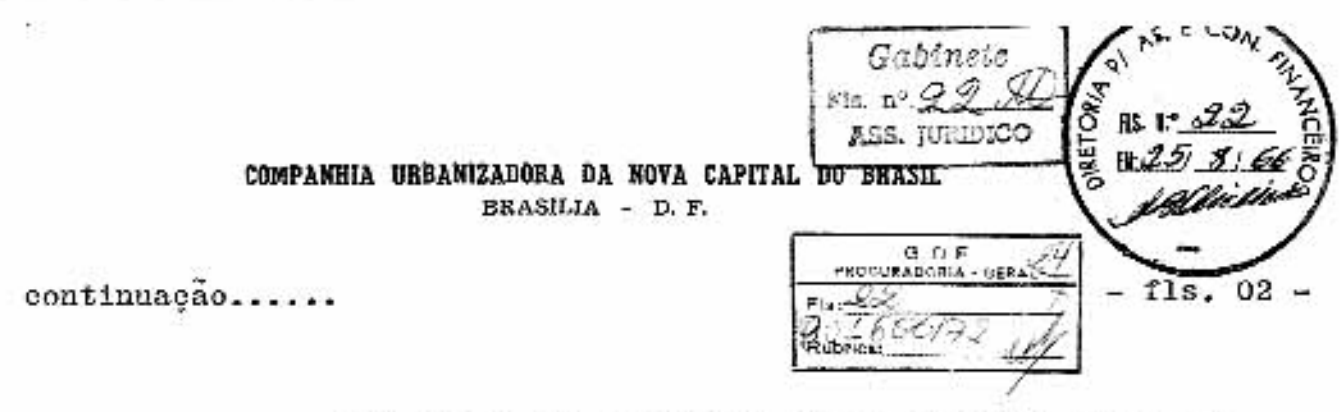

F) a a própria Unis̃o que recontece esta propriedade imobiliária cluando untoriza, j Novacap, a fazer estas desapro priagñes al.ravós de sous 6 rg̃̃os on detoraina ì sua própria prooura dorła Geral que o raga, conforme processos ajuizados en Brasilia e c口 São Paulo.

I foi a jrópria Justiga bo vistrito vederal ate = assin antencleu quando lêz varias desapropriaçoos, atendendo a perli do da NOVACAP.

Assim a uodificaço do ontendiatato, sew expedir

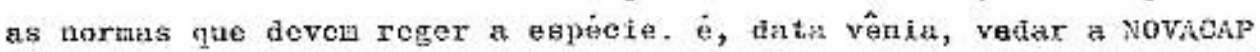
gue cunpra as disposiçoos que the forau impostas por Lei, é prejudicar a consolidašro tio Brasilia.

- Assin e aterdendo necessidade du desupropriagán = solicitada $\theta$ atendendo que rão existe nenhum dispositivo revosando o art. 15, da Lei $2,874 / 56$, opingnos para cue seja o prescrte, antes du decisto final, encalainato a Assessoria Jurítica para un parecer conclusivo sobre o assunto aquí ventilado.

\section{E O PARECER,}

Brasílja, 21 de agôsto de 1.966

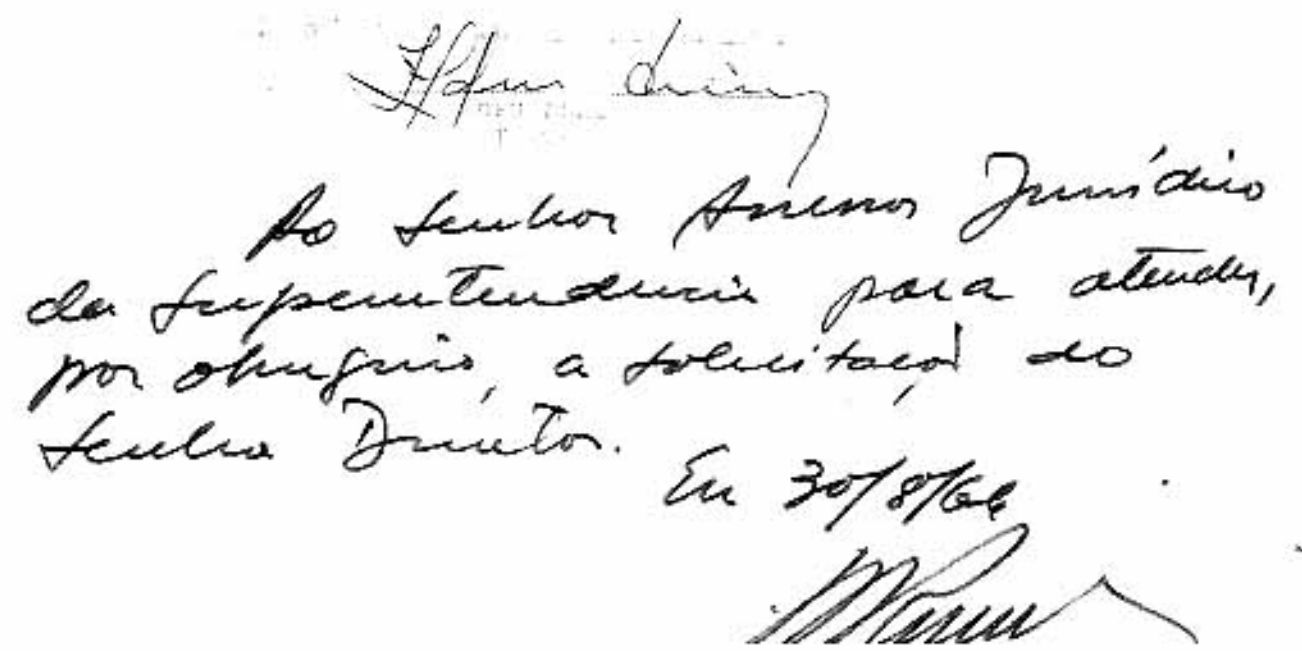


COMPAYHL UBBAMIZADORA DE MUVA CAPITAL DO BRASL ERASILIA - D. F.

Cabineve

F. $n^{0} \cdot 23-8$

Ass. formto

$\begin{array}{ll}\text { Parecer n? } & 101 / 66 \\ \text { Poocesson? } & 06.249 \\ \text { Interesendix. } & \text { ILUEU DE SOUZA LOBO }\end{array}$

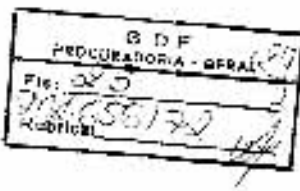

Asaunto : Uesapropriașão anigável de área da fazenda "RE'rRO DOS OLIOS D'AGUA".

1.

ILDEU DE SOJZA LOBO, proprietério de uma gleba de

17,5 alqueires de terras de campo e cultura, situada na fazenda "REXIRO DOS OLHOS $D^{2}$ AGUA", no Distrito Federal, propôs à Companhia a desapropriação amigável da aludida gleba ao preço de... Cr\$200.000 o alq queirc, sem condição.

2.

Após o costumciro trâmite, e avaliada a tobleba com a concordância do Interessado, foi o expediente encaminhado à Viretoria para decisäo. O Relator da matéria, entretanto, ten do en vista as dúvidas que vêm sendo suscitadas no âmbito da Justiça do Distrito Federal, no concernente à propriedade das terras constituintes do atual Distrito Federal, entendendo alguns magiatrados que as mesmas são insusceptíveis de desaproprlaçäo, por já pertencerem â Unifio, - opinou pela prévia audiência desta Ašsessoria, a fjm de que a resper to se pronuncie em parecer conclusivo.

3. s."

Para dirimir de vez as aludidas dúvidas, faremos um

País. rápido histórico sốbre as terras do domínio público no

Recuando aos primórdios da formação da propricdade no Brasil, verifica-se que tôda a terra pertencia, iniciolmente, à corôa portuguĉsa, por direito de conquista, consiltuindo, portanto, domínio público. Durante o perfodo colonial, como depois da independềncia, êsse domínio foi-se desmembrando, de acôrdo com us princípios de direito regradores da trangferéncia da propriedade do poder público para os particularea e dêstes entre si.

Fin virtude das transferências verificadis, os bens imóvels no Brasil, a princípio de propriedade exclusiva do tistado, passaram a constituir duas grandes classes: a dos bens públicos e da dos bens particulares.

Antea de proclamada a independência, an terras nắo consideradas indispensáveis à segurança do Ëtado, eram iransmitidas ao domínio particular, sem restriçōes, por doasão ou compra e por posse legitimada.

4.

O principal processo de transferência consistia na outorba das chamadas "cartas de scamarias".

$\Lambda$ Resoluçäo de 15 de março de 1731 , que regulou a con cessão das sesmerlas, proibia que estas se dessem "nas margens dos rios caudalosos que se for em descobrindo nos sertôes, e necessitam de

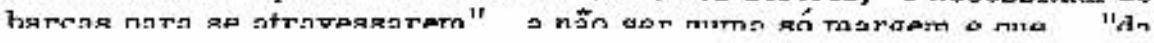




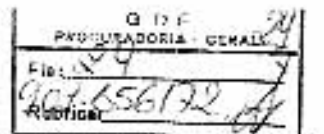

$$
\begin{aligned}
& \text { COMPANHIA URBAXIZADORA DA NOYA CAPTIRL DU BHTSIL. } \\
& \text { BRASILIA - D. } P \text {. } \\
& -2 \text { - }
\end{aligned}
$$

Gabinece of

FIn. $n^{n} \cdot 24-24$

x.SS. TPM do

zesse a reaerva para o público de uma e outra margens, assim como se deixasse de uma delas, livre para comodidade do povo e para uso de qualquer arrendatário da passagem, a extensão de meia-légua.

Fuxcluílas as margens dos rios navegáveis, ou que se fizcssem tais, as faixas indispensiveis à defesa nacional, e os terrenos da marinha, que nāo se transferiam ao domínio particular, podendo ser transferido apenas o domínio útil, por contratos de aforamento, as derriais terras podiam passar para o domínio particular sem resiriçôes, aendo inúmeras as Ordens, Cartas Régias, Resoluçôes, Provisōes, e Alvarás que, desde os tempos do Brasil-Colônia, traçaram as normas de concessões das terras devolutas.

5 .

Os diversos diplomes sobre o assunto foram consolidados na Lei Imperial n? 601, de 18 de setembro de 1850 , que sistematizou o regime de terras no Brasil, documcnto da mais alta importância, por constituir o fulcro principal em que se asserita a propriedade privada entre nós.

Tssa Lei, para cuja execução foi promulgado o Regulizmento no 1318, de 20 de janeiro de 1854, tem como tópicos fundamentais:

a) - a definição de terraa devolutas;

b) - a proibição dá aquisiçäo delas por ou - tro título que não seja o de compra, salvo concessão a particulares, por ela prescrita em caráter excepcional;

c) - a revalidação das sesmarias e outras doaçöes do Govêrno Geral ou provincial;

d) - a legitimação das posses mansas e pacíficas; e

e) - a prescriçảo do comisso.

6.

Ho ser proclameda a República, tôdas as terras devolu tas, a não ser as doadas pela União às províncias pelas leis ns. 514 , de 28 de outubro de 1848 , e 3.396 , de 24 de novembro de 1888, aquelas na quantidade de seis (6) léguas em quadro e estas, na porçảo de 360.000 (trezentos e sessenta mil) hectares - pertenciam à Nação, como consectário natural do regime unitário entāo vigorante.

Promulgada a primeira Constituição republicana, a 24 de fevereiro de 1891 , foi o regime territorial completamente alterado pelo seu art. 64, que prescreveu pertencerem aos Estados as minas e terras devolutas situades nos seus reapectivos territórios, cabendo à Uniảo sòmente a porçảo de texritório que fôr indispensável para a defesá das fronteiras, fortificaçōes, construçōes militares e estradas de ferro federais.

Além da porção de território referida na parte final do art. 64, reservou dita Constituição no seu art. 3\%, à União, mais á área de 14. 400 quilómetros quadrados no Planalto Central da República, que seria oportunameate demarcada para nela estabelecer-se a futura Capital 

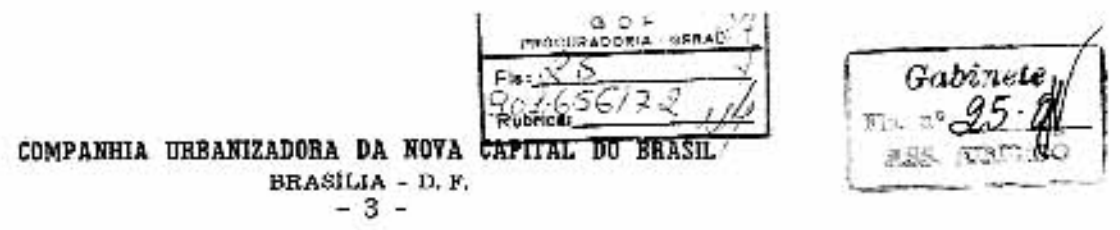

7.

kssa reserva, entretanto, era, e nem podia deixar de ser, de terras devolutas.

Leỉ n.601, de 1850 eram:

E terras devolutas, na definição do art. $3{ }^{\circ}$ da citada -

a) - as que não se achavam aplicadas a algum uso público nacional a provincial (e as do planalto central não es tavam destinades a tal uso);

b) - as que näo ge achavam sob o domf́io particuiar por qualquer título;

c) - as que nảo se achavam dadas por ses marias ou outras concessôes do govêrno, megmo que incursas em comisso, por terem gido revalidadas pela referida Lei;

d) - as que näo se achavam ocupadas por posses, quc, apesar de nảo se fundarem em título legítimo, foram legitimadas pela meama lei.

Se a reserva determinada pelo citado art. 39 da Constituição de 1891 , se referia a terras devoluias, ć fora de dúvida que nāo abrangia as que eativesaem sob o dománio particular. Isto é de clareza meridiana e espanca qualquer dúvida que a respeito se possa suscitar.

Vale dizer, portanto, que tôdos os detentores de terras na área do planalto central, mediante aquisição por qualquer título legítimo, dadas por sesmarias ou ocupadas por possea registradas, nos têrmos do disposto no art. 91 do Regulamento de 30 de janeiro de 1854 , só poderāo ser delas desapossados ou expropriados atraves do processo de desapropriação amigável ou judicial.

Nessa conformidade, mesmo que ainda vigente ou estivesse a Teserva prevista no citado dispositivo constitucional, não vigoraria contra os particulares, só podendo versar sôbre as terras devolu tas que, nessa hipótese, não se terlam transferido a domínio do

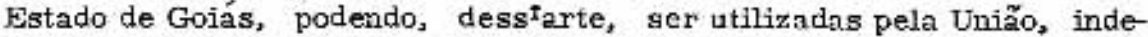
pendente de indenização a êsse Estado.

Ora, as terras de cuja desapropriaçäo amigável cogita - processo em exame pertencem ao interessado, que sóbre as mesmas provou o seu domínio, nĩo havendo assim nada que impeça a sua desapropriação pela NOVACAP.

8.

Nem se alegue que, pelo fato de terem sido reservadas para uso da União, tais terras foram excluídes do domí nio particular, por isso que, quando a reserva se fêz, já se achavam clas incorporadas a êsae domínio por disposição de lei e da Constituiçảo Imperlal, cujo art.179, n? 22, garantiu o direito de propriedade em tồda a sua plenitude, só permitindo o uso e o emprêgo da propriedade do eidadäo mediante prévia indenização. 


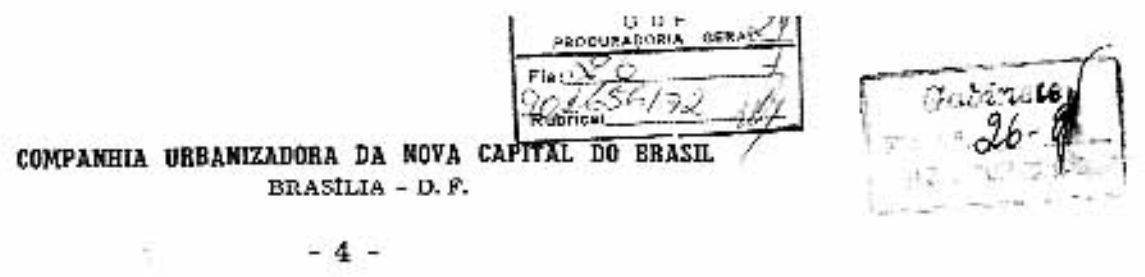

-das as terras em poder dos particulareg por fôrça da Lei n. 601, de 1860, cujo direito de propriedade estava garantido, em tôda sua plenitude, pela Constituição Imperial, só poderiam ser retiradas do domínio de seus titulares por meio da desapropriaçäo, por necegsidade ou utilidade públí ca mediante indenização prévia, nos têmos do $\$ 17^{\circ}$ do art. 72 dessa própria Constituição republicana, que, como a Imperial, manteve, em tôda a sua plenitude, a propriedade particular.

E manter significa conservar o que já existe: manteve ela, portanto, a propriedade, tal como já existia, à data de sua promulgação, Ademais, essa Constituição não revogou nem mesmo as leis do antigo regime, que, explicita ou implieitamente nảo fossem contráriza ao sistema de Govêrno por ela instituído, segundo rezava o seu artigo 83 .

Assim sendo, continuaram a pertencer nos particulares as terras que en 24 de fevereiro de 1891 . ac achavam incorporadas ao domínio particular, e, mais do que isso: a favor dos ocupantes ou pos suidores de tais terras continuaram a correx os prazos prescricionais para a sua aquisiçäo por usocapião.

Dessiarte, mesmo aquélea ocupantes de terras no planalto central, que näo detivessern títulos. de propriedade mas que registraram guas posses na forma estabelecida no art. 91 dó Regulam ento de 1854, adquiriram a sua propriedade por usacapiño, uma vez que o registro, mesmo feito perante os vigários de cada freguegia, constitui documento autêntico, como instrumento público, e possui fốrça proban te da posse, que, revestida dos requisitos de continuidade, boa-fé é pacificidade, gera o usocapiāo ordinário ou extraordinário, tanto no âmbito das relaçōes privadas, quanto no das relaçóes dog particulares com o Estado, no tocante aos bens do domínio público, entre os quais estão incluídis as terras devolutas.

F rão é só: mesmo os que não leyaram a registro as aus posses, ume vez cumprido o prazo prescricional, adquiriram a propriedade das terras possuídas, por usocapiäo.

Hoje ninguém mais pode sustentar, com qualquer viso de procedência, a imprescriptibilidade das terras públicas, a näo ser a partir da vigência dos Decretos ns.19.921, de 1931 e 22.785 , de 31 de maio de 1033 , que estabeleceram, de modo expresso, essa impres criptibilidade.

Aliás, bem examinados,tais decretos, que estabelecem odioso privilégio em favor do Estado, deveriam ser considerados revogados pela Constituição Federal de 1946, uma vez que o $\$ 3$ do seu artigo $15 \%$, prescreve o usucapiajo especial de 10 anos das terras públicas em favor dos agricultores. Tais decretos tornaram-se, pois, incompa tíveis com o sistema da nova Constituição.

9.

Regla-nos examinar, por último, mais um aspecto da qucstão.

Afirmanos, linhas acima, que se vigente estivesse a. reserva feita para a Uniäo dos 14.400 quilốmetros quadrados de terras do planalto central, o seu efeito operaria apenas em relaçảo ao Esíado de Goiás, a cujo patrimônio não teria aderido tal área, por fốrça do 


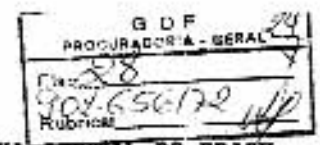

COMPANHIA URBAMIZADORA DA KOVA CHPITAL DO BRASII

BRASILIA - D. F.

-6 -

E. o disposto no $\$ 2$ dêsse artigo dejxa claro a inexistên cia de qualquer reserva anterior, quando prescreve que o estudo previsto no \$1 1 "será encaminhado ao Congresso Nacional, que deliberará a respeito, em lei espeeial, e estabelecerá o prazo para o início da de limitação da área a ser incorporada ao domínio da União".

Nada mais é de mister se acrescentar para demonstrar a caducidade da reserva feita pelo art. $3^{\circ}$ da Constikuição de 1891 . Esse disposittivo, além de nâo ter sido incorporado às Constituiçōes posteriores, perdendo assim a sua categoria de preceito constitucional, foi por estas revogado, pois que, tanto a de 1934, como a de 1946, dispu seram a respeito do assunto néle versado de modo diferente.

$\lambda$ vista do exposto, nosaa conclusão é no sentido de que nada obsta a que a NOVACAP, em cumprimento à lei que a instituiu,pro mova não só a desapropriação cogitada neste processo, como as demai.s que se fizerem necessáxias à integraçäo de tốda a área do Distrito Fede ral no seu patrimônio.

to parecer, S.M.J.

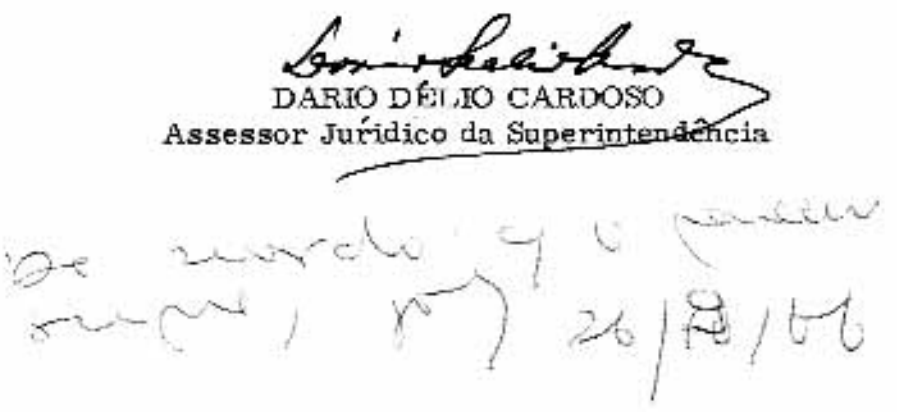

/ejn. 